UNIVERSIDADE DE BRASÍLIA

FACULDADE DE TECNOLOGIA

DEPARTAMENTO DE ENGENHARIA CIVIL E AMBIENTAL

PÓS-GRADUAÇÃO EM TECNOLOGIA AMBIENTAL E RECURSOS HÍDRICOS

ABORDAGEM METODOLÓGICA PARA AVALIAÇÃO AMBIENTAL DE ATIVIDADES E EMPREENDIMENTOS HIDROVIÁRIOS

MATEUS SALOMÉ DO AMARAL

ORIENTADOR: OSCAR DE MORAES CORDEIRO NETTO

DISSERTAÇÃO DE MESTRADO EM TECNOLOGIA AMBIENTAL E RECURSOS HÍDRICOS

PUBLICAÇÃO: PTARH.DM - 166/2014

BRASÍLIA/DF: NOVEMBRO - 2014 
UNIVERSIDADE DE BRASÍLIA

FACULDADE DE TECNOLOGIA

DEPARTAMENTO DE ENGENHARIA CIVIL E AMBIENTAL

PÓS-GRADUAÇÃO EM TECNOLOGIA AMBIENTAL E RECURSOS HÍDRICOS

\section{ABORDAGEM METODOLÓGICA PARA AVALIAÇÃO AMBIENTAL DE ATIVIDADES E EMPREENDIMENTOS HIDROVIÁRIOS}

MATEUS SALOMÉ DO AMARAL

DISSERTAĈ̃O SUBMETIDA AO DEPARTAMENTO DE ENGENHARIA CIVIL E AMBIENTAL DA FACULDADE DE TECNOLOGIA DA UNIVERSIDADE DE BRASÍLIA COMO PARTE DOS REQUISISTOS NECESSÁRIOS PARA A OBTENÇÃO DO GRAU DE MESTRE EM TECNOLOGIA AMBIENTAL E RECURSOS HÍDRICOS.

APROVADA POR:

Prof. Oscar de Moraes Cordeiro Netto (ORIENTADOR)

Prof. Wagner dos Santos Almeida

(EXAMINADOR INTERNO)

Profa. Teresa Lúcia Muricy de Abreu (EXAMINADORA EXTERNA)

BRASÍLIA-DF, 12 DE NOVEMBRO DE 2014. 
AMARAL, M. S.

ABORDAGEM METODOLÓGICA PARA AVALIAÇÃO AMBIENTAL DE ATIVIDADES E EMPREENDIMENTOS HIDROVIÁRIOS.

xvii, 176p., 210 x 297 mm (ENC/FT/UnB, Mestre, Tecnologia Ambiental e Recursos Hídricos, 2014). Dissertação de Mestrado - Universidade de Brasília. Faculdade de Tecnologia. Departamento de Engenharia Civil e Ambiental.
1. HIDROVIAS
2. AVALIAÇÃO AMBIENTAL
3. LICENCIAMENTO AMBIENTAL
4. PLANEJAMENTO
I. ENC/FT/UnB
II. Título (série)

\section{REFERÊNCIA BIBLIOGRÁFICA}

AMARAL, M. S. (2014). Abordagem Metodológica para Avaliação Ambiental de Atividades e Empreendimentos Hidroviários. Dissertação de Mestrado em Tecnologia Ambiental e Recursos Hídricos, Publicação PTARH.DM-166/2014, Departamento de Engenharia Civil e Ambiental, Universidade de Brasília, Brasília, DF, 176p.

\section{CESSÃO DE DIREITOS}

NOME DO AUTOR: Mateus Salomé do Amaral TÍTULO: Abordagem Metodológica para Avaliação Ambiental de Atividades e Empreendimentos Hidroviários.

É concedida à Universidade de Brasília permissão para reproduzir cópias desta dissertação de mestrado e para emprestar ou vender tais cópias somente para propósitos acadêmicos e científicos. O autor reserva outros direitos de publicação e nenhuma parte dessa dissertação de mestrado pode ser reproduzida sem autorização por escrito do autor.

\footnotetext{
Mateus Salomé do Amaral Travessa dos Ficos, 1 - Vila Planalto CEP: 70804-210 - Brasília - DF
} 
Dedico este trabalho aos meus pais, irmão, noiva, amigos e familiares, como forma da minha gratidão. 
"O rio atinge seus objetivos, porque aprendeu a contornar os obstáculos." Lao Tsé 


\section{AGRADECIMENTOS}

Aos meus pais Geraldo Majela e Soniamar, responsáveis por tudo o que sou, meu infinito agradecimento.

Ao meu irmão Pedro, pela amizade, atenção e apoio sem reservas.

À minha querida noiva Renata, por estar sempre ao meu lado, por seu companheirismo, paciência, compreensão e amor.

Aos meus familiares, tios, primos, cunhados e sogros, pelo incentivo e suporte ao longo destes anos.

Ao meu orientador, Prof. Oscar, por dividir seu conhecimento e experiência comigo e pelas valiosas contribuições para o trabalho.

A todos os colegas, professores e funcionários do PTARH. Aos professores, agradeço os ensinamentos e a partilha do saber, aos colegas, pela agradável convivência, pelo apoio nos estudos e pelo aprendizado conjunto e aos funcionários, a atenção e o carinho.

Aos professores, Wagner Almeida, Teresa Abreu e Conceição Alves, pela participação nos seminários e na banca da defesa.

Aos colegas de trabalho por me apoiarem e ajudarem nesta caminhada.

Aos companheiros de moradia pelos momentos vividos juntos e pela força em todos os momentos.

A todos os meus amigos e àqueles que, de maneira direta ou indireta, contribuíram para a realização deste trabalho. 


\title{
RESUMO
}

\section{ABORDAGEM METOdOLÓGICA PARA AVALIAÇÃo AMBIENTAL DE ATIVIDADES E EMPREENDIMENTOS HIDROVIÁRIOS}

\author{
Autor: Mateus Salomé do Amaral \\ Orientador: Oscar de Moraes Cordeiro Netto \\ Programa de Pós-Graduação em Tecnologia Ambiental e Recursos Hídricos \\ Brasília, novembro de 2014.
}

O Brasil apresenta um enorme potencial para o transporte hidroviário interior, que oferece vantagens, principalmente, para o transporte de grandes quantidades a grandes distâncias e não deve estar ausente em um sistema de transportes intermodal eficiente. No entanto, o tratamento das questões ambientais dos projetos hidroviários tem apresentado grandes controvérsias, que se refletem especialmente nos processos de licenciamento ambiental desses empreendimentos. Ademais, não existem normas específicas para avaliação das questões ambientais dos empreendimentos e atividades de infraestrutura para o transporte hidroviário interior. Assim, buscou-se nesta pesquisa a formulação de uma abordagem metodológica que auxilie na definição de um processo de avaliação ambiental de atividades e empreendimentos hidroviários. Para isso, utilizou-se de pesquisas bibliográficas e documentais, assim como em levantamento de informações com especialistas e entidades com experiência no assunto, para uma melhor compreensão sobre o transporte hidroviário interior e a questão ambiental relacionada a esse modo de transporte. Além das análises quanto aos pontos críticos encontrados nos procedimentos, foram desenvolvidas propostas de abordagens para o processo de planejamento e licenciamento ambiental. Apesar de ser apenas uma contribuição para a avaliação ambiental de projetos hidroviários, verificou-se, por meio de consulta a especialistas e pela aplicação a uma situação hipotética, a aplicabilidade das propostas.

Palavras-chaves: hidrovias, avaliação ambiental, licenciamento ambiental, planejamento. 


\title{
ABSTRACT \\ METHODOLOGICAL APPROACH TO ENVIRONMENTAL ASSESSMENT OF WATERWAY ACTIVITIES AND PROJECTS
}

\author{
Author: Mateus Salomé do Amaral \\ Supervisor: Oscar de Moraes Cordeiro Netto \\ Programa de Pós-Graduação em Tecnologia Ambiental e Recursos Hídricos \\ Brasília, November 2014.
}

Brazil has a huge potential for inland waterway transport, which offers advantages, especially for the transport of large quantities over long distances and should not be absent in an efficient intermodal transport. However, the treatment of environmental issues of waterway projects has brought great controversy, reflected especially in the processes of environmental licensing of these developments. Moreover, there are no specific standards for evaluating environmental issues of projects and infrastructure activities for inland waterway transport. Thus, in this study we aimed to formulate a methodological approach that assists in defining a process of environmental assessment of waterway activities and projects. For this, we used the bibliographic and documentary research, as well as gathering information from experts and entities with experience in the subject to a better understanding of inland waterway transport and the environmental issues related to this mode of transport. Besides the analysis for critical points found in the procedures proposed approaches for process planning and environmental licensing were developed. Despite being only a contribution to the environmental assessment of waterway projects, it was found, through expert consultation and application to a hypothetical situation, the applicability of the proposals.

Keywords: waterways, environmental assessment, environmental licensing, planning. 


\section{LISTA DE FIGURAS}

Figura 3.1 - Representação esquemática da metodologia.

Figura 5.1 - Extensão, em quilômetros $(\mathrm{km})$, dos principais sistemas de navegação (Europa Ocidental, Estados Unidos, China e Rússia), divididos em calados maiores e menores que $2,75 \mathrm{~m}$. 30

Figura 5.2 - Matriz de transportes brasileira no ano de 2005 e projeção para 2025. 37

Figura 5.3 - Distribuição modal esperada no Brasil, entre 2011 e 2031.

Figura 6.1 - Regiões Hidrográficas do Brasil de acordo com a Resolução CNRH no 32, de 15 de outubro de 2003. .51

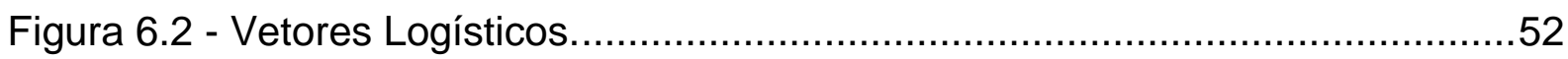

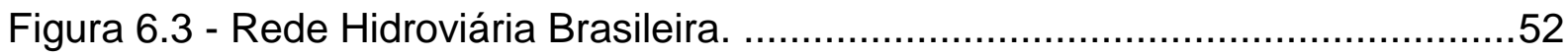

Figura 7.1 - Diagrama das obras e serviços para melhoramento em cursos d'água brasileiros.

Figura 7.2 - Fluviograma do posto limnimétrico de São Félix do Araguaia, no Rio Araguaia, ano de 1983, apresentando o provável período de execução da dragagem.

Figura 8.1 - Matriz de causas e consequências da dragagem do leito do rio. 107

Figura 9.1 - Abordagem para o planejamento no setor de transporte hidroviário interior. 122

Figura 9.2 - Fluxograma representativo da proposta metodológica para a definição do procedimento de licenciamento ambiental de projetos hidroviários.

Figura 9.3 - Fluxograma representativo da proposta inicial de tratamento ambiental para atividades de manutenção. 138

Figura 9.4 - Fluxograma representativo da proposta de tratamento ambiental para atividades de manutenção, considerando a emissão de licença de operação. 140 Figura 9.5 - Fluxograma representativo da proposta de tratamento ambiental para atividades de manutenção, considerando a emissão de autorização. 141

Figura 9.6 - Abordagem para o planejamento no setor de transporte hidroviário interior após consulta aos especialistas. 143

Figura 9.7 - Fluxograma representativo da proposta metodológica para a definição do procedimento de licenciamento ambiental de projetos hidroviários após consulta aos especialistas. 
Figura 9.8 - Caracterização e classificação dos trechos navegáveis dos rios Anchieta

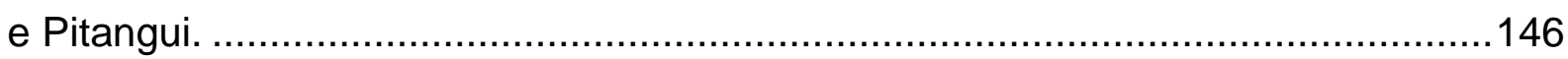

Figura 9.9 - Alteração de classe do Trecho A-B............................................147

Figura 9.10 - Atividades que buscam transformar o Trecho C-D, em que não há ou teve navegação, em navegável.................................................................147 Figura 9.11 - Construção de um canal fazendo a interligação hidroviária entre os rios Anchieta e Pitangui. 148 


\section{LISTA DE QUADROS}

Quadro 5.1 - Principais planos nacionais de viação no século XIX e suas características.

Quadro 5.2 - Parâmetros de transporte para os modos rodoviário, ferroviário e aquaviário.

Quadro 5.3 - Comparação de Fretes por modo de transporte (US\$ / t . $1000 \mathrm{~km}$ )....44 Quadro 5.4 - As cinco dimensões (velocidade, confiabilidade, capacitação, disponibilidade e frequência) referentes às características operacionais dos serviços oferecidos por cada um dos modos de transporte.

Quadro 5.5 - Custos externos (ou sociais) levantados por simulação para o transporte de cargas de longo curso na Bélgica em um ano, para caminhões, trens e barcos. 45

Quadro 5.6 - Custos sociais em relação às modalidades de transporte (\%). .45

Quadro 6.1 - Relação Descritiva das Hidrovias do Plano Nacional de Viação. .47

Quadro 6.2 - Interligação de Bacias do Plano Nacional de Viação. 49

Quadro 6.3 - Rede Hidroviária Brasileira em 2005. .50

Quadro 6.4 - Bacias Hidroviárias segundo o Ministério dos Transportes e respectivas Administrações Hidroviárias.

Quadro 7.1 - Proposta Sintética para o desenvolvimento da tese de Santana (2008). .55

Quadro 7.2 - Atributos do transporte hidroviário interior .58

Quadro 7.3 - Visão sistêmica dos elementos, fases do projeto e efeitos ambientais. .59

Quadro 7.4 - Classificação das Hidrovias Interiores na Europa. .67

Quadro 7.5 - Classificação das hidrovias segundo PIANC. 68

Quadro 7.6 - Extensão da Rede Hidroviária Brasileira por Bacia Hidrográfica. 69

Quadro 7.7 - Classificação das vias navegáveis segundo PNVNI (1989). .70

Quadro 7.8 - Tipos de vias navegáveis e as técnicas para melhorar a navegabilidade. .73

Quadro 7.9 - Compilação das atividades e empreendimentos hidroviários. .78

Quadro 7.10 - Principais tipos de dragas. .88

Quadro 8.1 - Normas da Autoridade Marítima - NORMAM. 119 
Quadro 9.1 - Situação da navegação e classificação dos trechos analisados nos rios

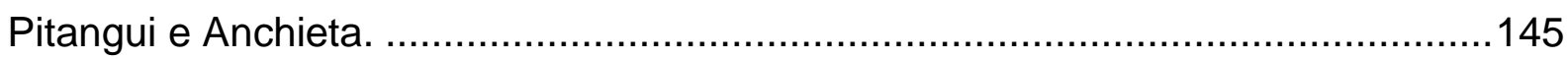
Quadro 9.2 - Compilação de informações das situações apresentadas na aplicação da metodologia. 


\section{LISTA DE ABREVIATURAS E SIGLAS}

$\mathrm{AEH}$

$\mathrm{AH}$

AHP

AIA

ALICEWeb

ANA

ANTAQ

$\mathrm{CNRH}$

CONAMA

$\mathrm{DHN}$

DNIT

ECMT

FUNAI

GPS

HEC-RAS

IBAMA

IPHAN

ISO

MDIC

MDT

MISAHA

MJ

MMA

MPF

MT

NATA

NORMAM

OECD
Atividades e Empreendimentos Hidroviários

Administração Hidroviária

Analytic Hierarchy Process

Avaliação de Impactos Ambiental

Sistema de Análise das Informações de Comércio Exterior via Internet

Agência Nacional de Águas

Agência Nacional de Transporte Aquaviário

Conselho Nacional de Recursos Hídricos

Conselho Nacional de Meio Ambiente

Diretoria de Hidrografia e Navegação

Departamento Nacional de Infraestrutura de Transportes

European Conference of Ministers of Transport

Fundação Nacional do Índio

Global Positioning System

Hydrologic Engineering Centers River Analysis System

Instituto Brasileiro do Meio Ambiente e dos Recursos Naturais Renováveis

Instituto do Patrimônio Histórico e Artístico Nacional

International Organization for Standardization

Ministério do Desenvolvimento, Indústria e Comércio Exterior

Modelo Digital de Terreno

Modelo de Indicadores de Sustentabilidade Aplicável a Hidrovias na Amazônia

Ministério da Justiça

Ministério do Meio Ambiente

Ministério Público Federal

Ministério dos Transportes

New Aproach to Appraisal

Norma da Autoridade Marítima para Auxílio à Navegação

The Organization for Economic Co-operation and Development 


$\begin{array}{ll}\text { ONG } & \text { Organização não Governamental } \\ \text { PIANC } & \text { The World Association for Waterborne Transport Infrastructure } \\ \text { PNGH } & \text { Plano Nacional de Gerenciamento Hidroviário } \\ \text { PNLT } & \text { Plano Nacional de Logística e Transportes } \\ \text { PNMA } & \text { Política Nacional do Meio Ambiente } \\ \text { PNV } & \text { Plano Nacional de Viação } \\ \text { PNVNI } & \text { Plano Nacional de Vias Navegáveis Interiores } \\ \text { PORTOBRAS } & \text { Empresa de Portos do Brasil S. A. } \\ \text { PPA } & \text { Plano Plurianual } \\ \text { PTARH } & \text { Programa de Pós Graduação em Tecnologia Ambiental e Recursos } \\ & \text { Hídricos } \\ \text { SGA } & \text { Sistema de Gestão Ambiental } \\ \text { SIG } & \text { Sistema de Informações Georreferenciadas } \\ \text { TCU } & \text { Tribunal de Contas da União } \\ \text { THI } & \text { Transporte Hidroviário Interior } \\ \text { UHE } & \text { Usina Hidrelétrica de Energia } \\ \text { UnB } & \text { Universidade de Brasília } \\ \text { USACE } & \text { United States Army Corps of Engineers }\end{array}$




\section{SUMÁRIO}

1. INTRODUÇÃO

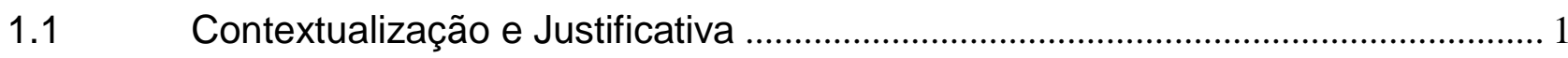

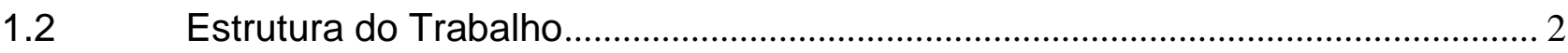

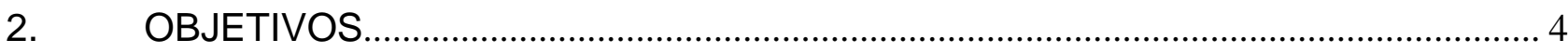

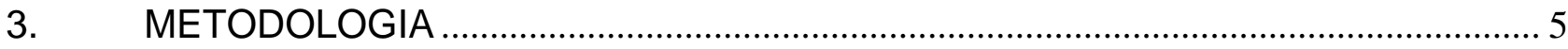

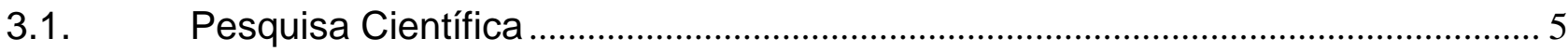

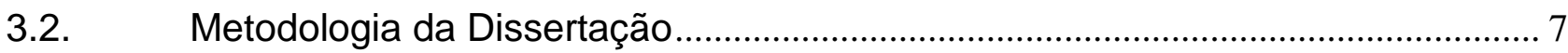

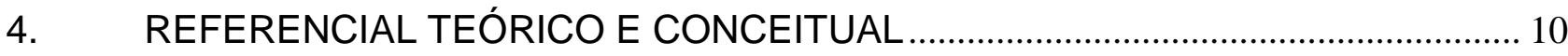

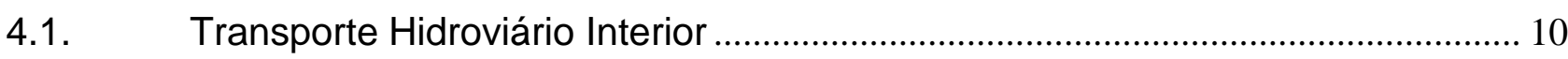

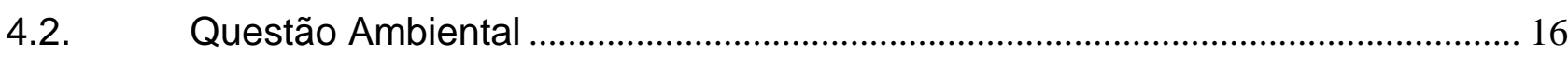

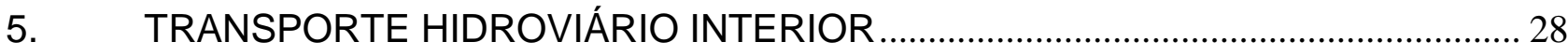

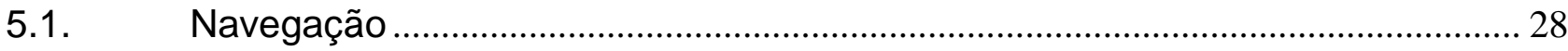

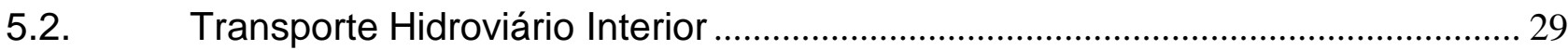

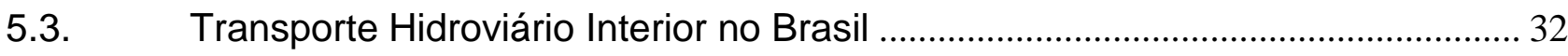

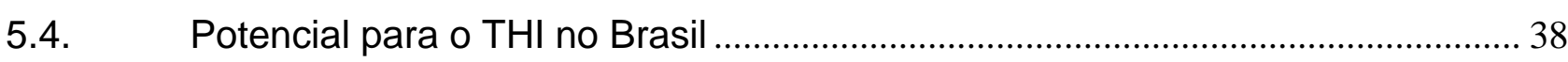

5.5. Características do Transporte Hidroviário …………………………...................... 41

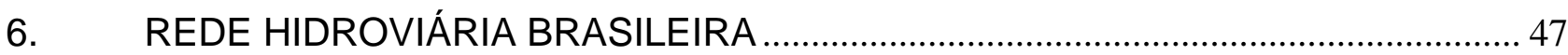

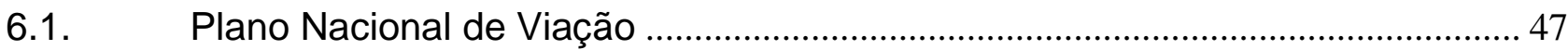

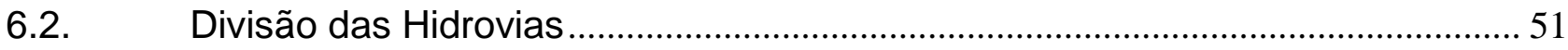

7. ATIVIDADES E EMPREENDIMENTOS HIDROVIÁRIOS ....................................... 54

7.1. Fases de Implantação de Sistemas de Transporte .................................................. 54

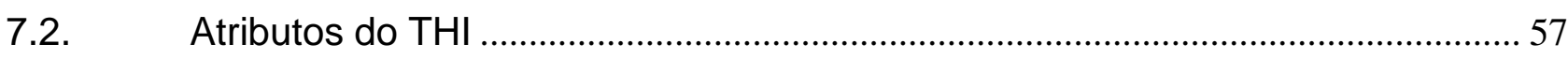

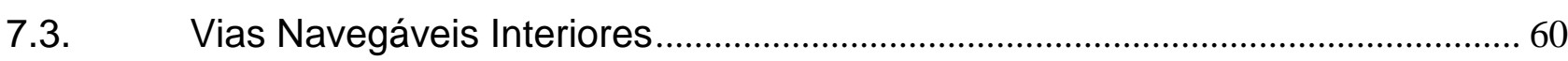

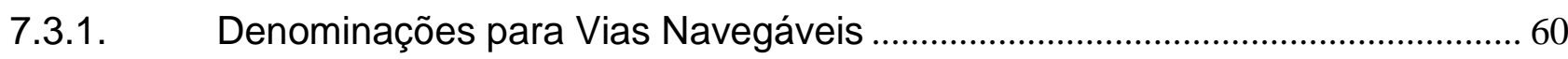

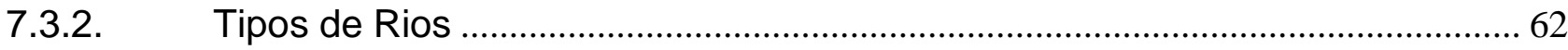

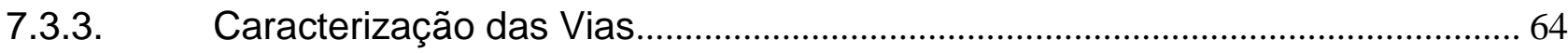

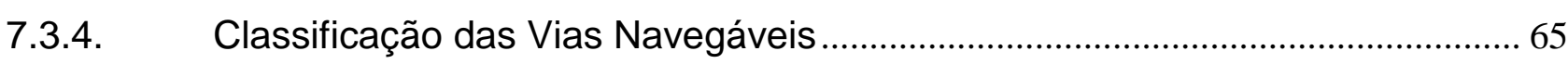

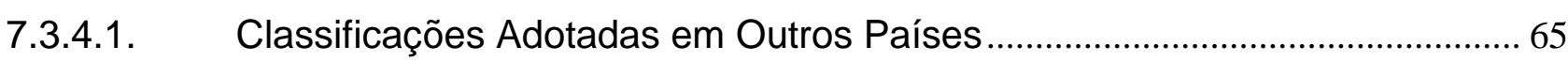

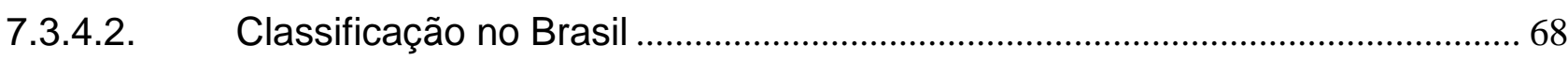

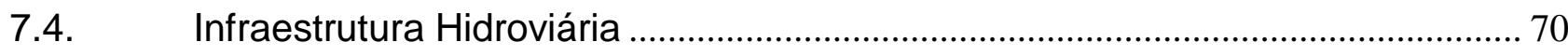

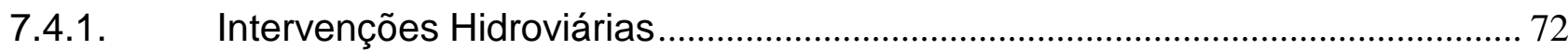




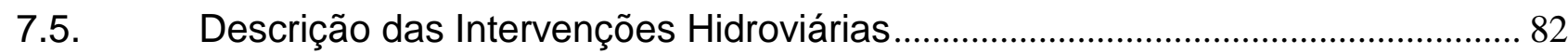

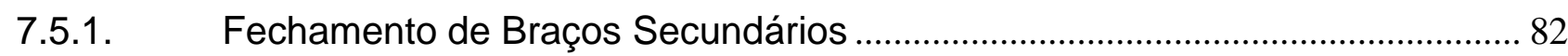

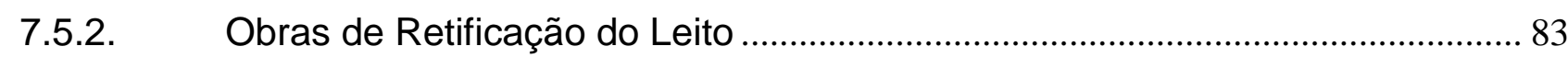

7.5.3. Contração Lateral do Leito e Limitação dos Leitos de Inundação ...................... 84

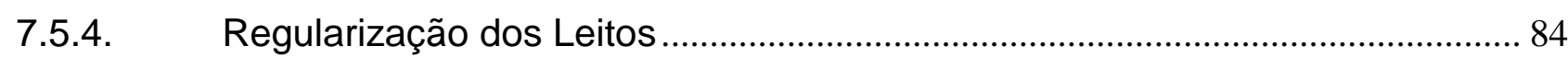

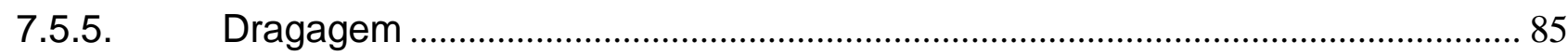

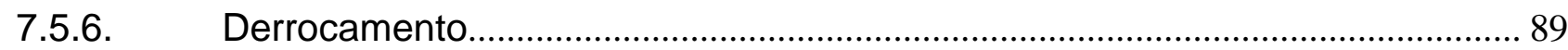

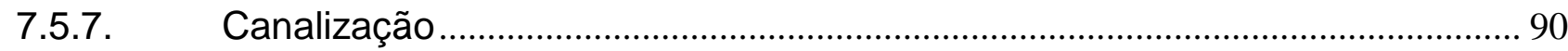

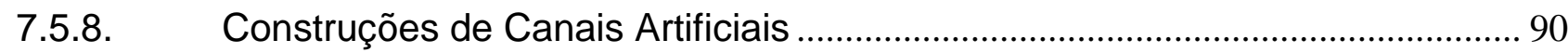

7.5.9. Serviços de Sinalização e Balizamento …………………………………............. 91

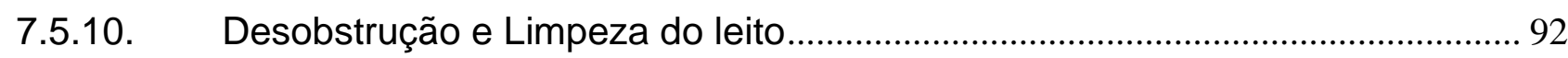

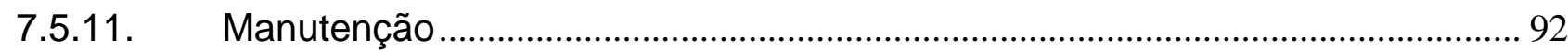

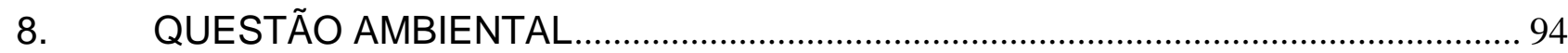

8.1. Impactos Ambientais dos Sistemas de Transportes ……………………............ 96

8.2. Impactos Ambientais dos Projetos Hidroviários................................................... 98

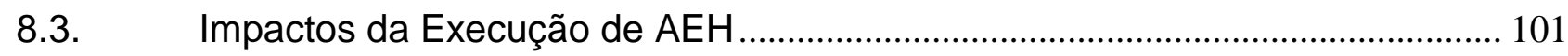

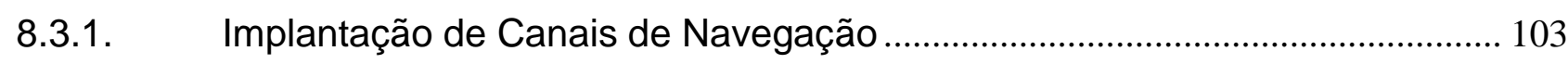

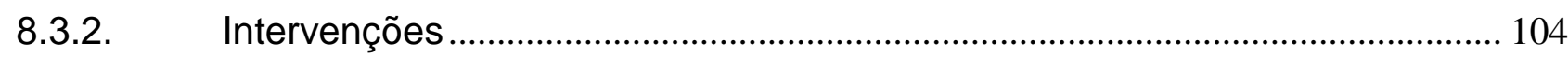

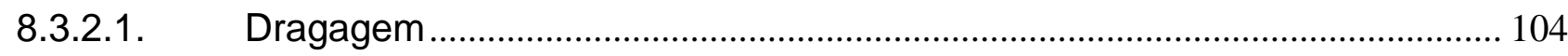

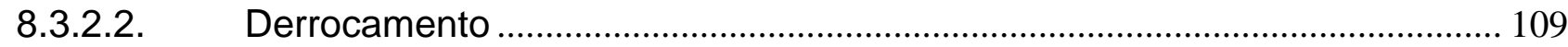

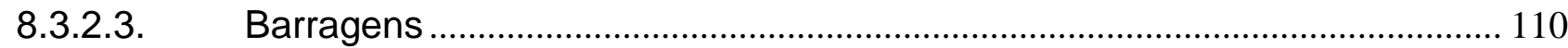

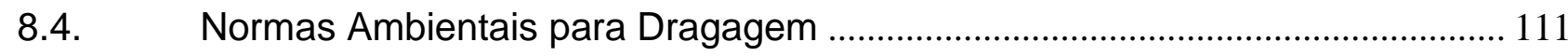

8.4.1. Elaboração e Revisão das Resoluções ............................................................ 113

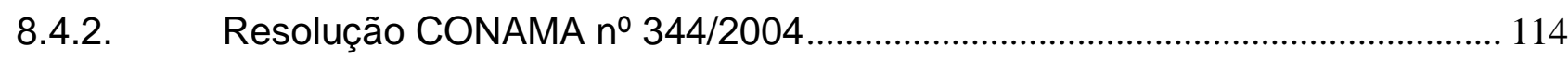

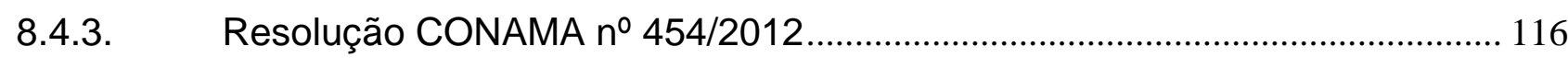

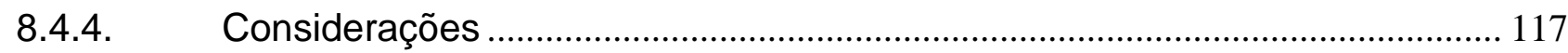

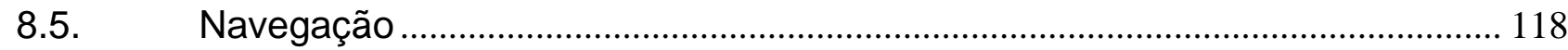

9. AVALIAÇÃO AMBIENTAL DE PROJETOS HIDROVIÁRIOS ................................ 120

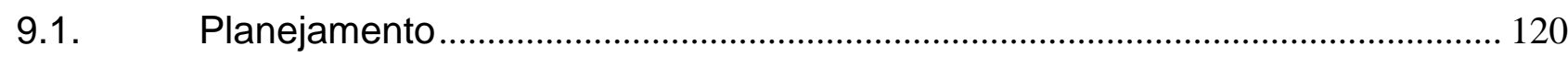

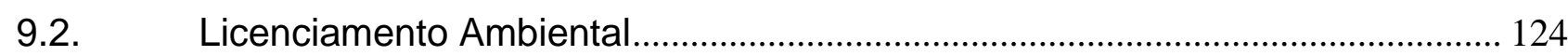

9.2.1. Objeto do Licenciamento Ambiental............................................................... 125

9.2.2. Procedimento de Licenciamento Ambiental..................................................... 131

9.2.3. Proposta para o Licenciamento Ambiental de AEH........................................... 134 


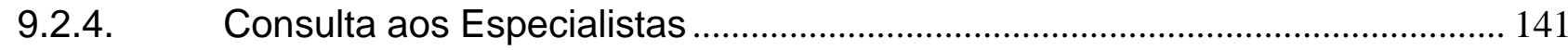

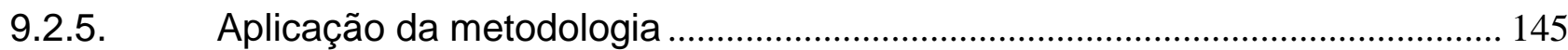

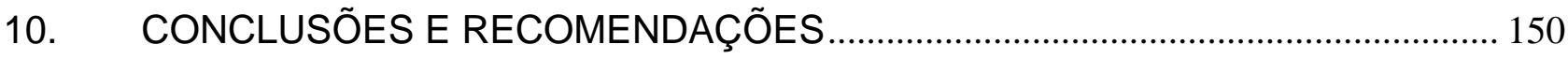

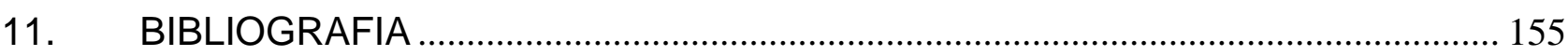

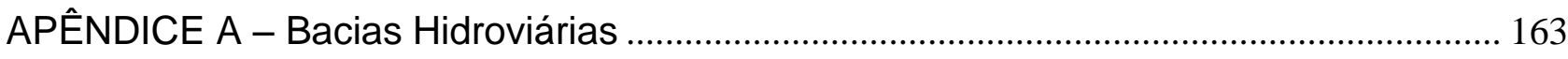

APÊNDICE B - Consultas aos Especialistas................................................................. 169 


\section{INTRODUÇÃO}

\subsection{Contextualização e Justificativa}

As hidrovias são conhecidas como alternativas de transporte de menor custo e impacto ambiental do que rodovias e ferrovias. O transporte hidroviário é mais eficiente, apresenta menor consumo de combustíveis e menos emissões de poluentes atmosféricos. Esse modo de transporte oferece vantagens, principalmente, para 0 transporte de grandes quantidades a grandes distâncias.

Contando com uma ampla rede de drenagem propícia à navegação, o Brasil apresenta um enorme potencial para o transporte hidroviário interior. Com o aumento da necessidade e importância do transporte hidroviário, tornaram-se mais evidentes os gargalos na infraestrutura e mais urgente a necessidade de obras de adequação, melhorias e, especialmente, manutenção nas vias navegáveis.

Por sua vez, maiores também são as preocupações ambientais da sociedade e as medidas que devem ser tomadas para proteção do meio ambiente. Nesse contexto, encontram-se os instrumentos da Política Nacional do Meio Ambiente, como a avaliação de impactos ambientais e o licenciamento ambiental.

No Brasil, o tratamento das questões ambientais dos projetos hidroviários tem apresentado grandes controvérsias, que vêm se refletindo nos processos de licenciamento ambiental desses empreendimentos. Existem posições contrárias e favoráveis ao incremento do transporte hidroviário interior e, mesmo nos setores favoráveis, há divergências na forma de analisar as questões ambientais.

Verifica-se que, diferentemente de outras tipologias, o licenciamento ambiental de atividades e empreendimentos hidroviários não conta com legislação ou normativo específicos, que o regulamente de forma clara. Ademais, posicionamentos divergentes em relação ao tratamento a ser dispensado a esses processos são encontrados na sociedade, representada por setores como as organizações não governamentais (ONG), entidades 
empresariais, profissionais do setor hidroviário e mesmo no âmbito dos governos.

Exemplo de posicionamentos opostos que se apresentam no processo de licenciamento desses empreendimentos reside na própria definição do objeto de licenciamento. Por um lado, alguns profissionais defendem que a via navegável se trata de um curso de água natural e, portanto não é passível de licenciamento, sendo o licenciamento aplicável apenas às obras civis. Por outro lado, existem aqueles que defendem o licenciamento de toda a hidrovia, independentemente das intervenções que venham a ser realizadas. Nesse segundo grupo, há, ainda, discussões de como esse processo de licenciamento da hidrovia deve ocorrer, considerando a grande área de influência da hidrovia. Esse se trata apenas de um exemplo que ilustra a divergência de opiniões, mas existem ainda várias outras questões para as quais não há consenso ou entendimento convergente.

Nesse contexto, julgou-se pertinente proceder a uma abordagem da avaliação ambiental dos projetos hidroviários, a fim de se verificarem os principais aspectos que devem ser considerados. Essa análise foi realizada para avaliar alternativas que podem ser consideradas na avaliação ambiental desses projetos, com o intuito de buscar se imprimir maior racionalidade a esse processo, de modo que, por um lado, os impactos ambientais sejam adequadamente considerados e, por outro, os projetos sejam considerados na proporção dos riscos a eles associados.

Para tanto, foi realizado um levantamento das características gerais do transporte hidroviário, um exame das particularidades das obras e atividades hidroviárias, bem como dos impactos ambientais dessas intervenções. Dessa forma, foi possível construir uma representação conceitual sobre a questão.

\subsection{Estrutura do Trabalho}

Primeiramente, neste Capítulo 1, são apresentados os elementos introdutórios da dissertação, incluindo a contextualização e a justificativa deste trabalho científico. No Capítulo 2, são explicitados os objetivos, geral e específicos, que traduzem os principais aspectos a serem alcançados. No 
Capítulo 3, a metodologia utilizada no desenvolvimento desta pesquisa é apresentada.

Em seguida, no Capítulo 4, desenvolve-se o referencial teórico e conceitual, tópico esse que apresenta a fundamentação para o desenvolvimento do trabalho. Nesse capítulo, são apresentadas as principais características do transporte hidroviário interior, fatores que afetam 0 desenvolvimento desse transporte no Brasil e questões ambientais relacionadas.

Nos Capítulos 5 e 6 são apresentadas as informações referentes ao Transporte Hidroviário Interior e às características gerais da navegação. Nesses capítulos são expostos dados comparativos entre os diversos modos, uma breve descrição do Transporte Hidroviário Interior (THI), um panorama histórico desse modo, bem como o potencial para o THI no País.

As atividades hidroviárias são detalhadas no Capítulo 7. Nesse capítulo, são apresentadas as fases de implantação de um sistema de transporte, os atributos do transporte hidroviário interior, dando destaque à via navegável interior. Discorre-se ainda sobre a classificação das vias navegáveis, no Brasil e no mundo. Por fim, são apresentadas as principais intervenções hidroviárias que podem ser realizadas nas vias navegáveis interiores.

O Capítulo 8 analisa a relação dos transportes com o meio ambiente, com foco nos impactos dos projetos de infraestrutura da via navegável. Apresenta-se nesse Capítulo, de forma geral, os principais impactos das obras e atividades hidroviários e as normas ambientais para dragagem, que são as únicas normas nacionais que tratam diretamente de projetos hidroviários.

O tratamento ambiental dos projetos hidroviários é discutido no Capítulo 9. Nesse Capítulo, apresentam-se propostas para o planejamento no setor hidroviário e para o licenciamento ambiental de atividades e empreendimentos hidroviários, além de realizar análises dos principais pontos relacionados ao licenciamento ambiental dessa tipologia.

Por fim, no Capítulo 10 são apresentadas as conclusões e recomendações obtidas a partir do desenvolvimento desta pesquisa. 


\section{OBJETIVOS}

Esta pesquisa tem como objetivo geral a formulação de uma abordagem metodológica que auxilie na definição de um processo de avaliação ambiental de atividades e empreendimentos hidroviários - $\mathrm{AEH}$.

Consideram-se, ainda, os seguintes objetivos específicos:

- Promover uma caracterização do transporte hidroviário interior, apresentando sua contextualização histórica e suas características;

- Identificar, descrever e classificar as intervenções necessárias à garantia da navegabilidade dos corpos d'água, bem como as questões ambientais relacionados às principais intervenções;

- Desenvolver e propor procedimentos aplicáveis à avaliação ambiental de atividades e empreendimentos hidroviários, no contexto brasileiro. 


\section{METODOLOGIA}

\subsection{Pesquisa Científica}

Uma pesquisa pode ser definida como um processo formal e sistemático de desenvolvimento do método científico de forma a se descobrirem respostas para problemas por meio de uso de procedimentos científicos. A pesquisa é um procedimento reflexivo e crítico de busca de respostas para problemas ainda não solucionados.

As pesquisas podem ser classificadas segundo vários critérios, entre eles:

$\checkmark \quad$ Da sua natureza

Segundo este critério a pesquisa pode ser básica ou aplicada. Uma pesquisa básica objetiva gerar conhecimentos novos para avanço da ciência sem aplicação prática prevista. Já uma pesquisa aplicada objetiva gerar conhecimentos, para aplicações práticas, dirigidos à solução de problemas específicos.

$\checkmark \quad$ Da natureza das variáveis pesquisas

Segundo esse critério a pesquisa pode ser quantitativa ou qualitativa. Em um estudo quantitativo o pesquisador busca obter uma medição precisa dos resultados quantificáveis obtidos e traduzir opiniões e números em informações as quais serão classificadas e analisadas. Já no qualitativo o pesquisador procura verificar um fenômeno por meio da observação e estudo do mesmo, ou seja, a pesquisa é descritiva.

\section{$\checkmark \quad$ Dos objetivos}

Sob este ponto de vista a pesquisa pode ser classificada em:

- Exploratória: objetiva proporcionar maior familiaridade com um problema. Tem como características principais a flexibilidade, a criatividade e a informalidade; envolve levantamento bibliográfico, entrevistas com pessoas que tiveram experiências práticas com 0 problema pesquisado e análise de exemplos; assume em geral a forma de pesquisas bibliográficas e estudos de caso.

- Descritiva: objetiva descrever as características de certa população ou fenômeno, ou estabelecer relações entre variáveis. Algumas hipóteses 
podem ser formuladas com base em conhecimentos prévios, procurando-se confirmá-las ou negá-las; envolvem técnicas de coleta de dados padronizadas (questionário, observação); assume em geral a forma de levantamento. Nesse tipo de estudo é extremamente importante a exatidão e precisão dos dados coletados.

- Explicativa: objetiva identificar os fatores que determinam fenômenos, explica o porquê das coisas; assume em geral as formas de pesquisa experimental e pesquisa ex-post-facto.

$\checkmark \quad$ Dos procedimentos técnicos

Em relação aos procedimentos técnicos uma pesquisa pode ser classificada como:

- Pesquisa bibliográfica: elaborada a partir de material já publicado, como livros, artigos, periódicos, Internet, etc;

- Pesquisa documental: elaborada a partir de material que não recebeu tratamento analítico;

- Pesquisa experimental: pesquisa em que se determina um objeto de estudo, selecionam-se variáveis que o influenciam, definem se as formas de controle e de observação dos efeitos que as variáveis produzem no objeto;

- Levantamento: pesquisa que envolve questionamento direto das pessoas cujo comportamento se deseja conhecer;

- Estudo de caso: envolve o estudo profundo e exaustivo de um ou poucos objetos de maneira que se permita o amplo e detalhado conhecimento;

- Pesquisa ex-post-facto: quando o experimento se realiza depois dos fatos;

- Pesquisa ação: pesquisa concebida em associação com uma ação; os pesquisadores e participantes da situação ou problema estão envolvidos de modo cooperativo ou participativo;

- Pesquisa participante: pesquisa desenvolvida pela interação entre pesquisadores e membros das situações investigadas;

Segundo esses critérios, o presente estudo pode ser classificado como uma pesquisa aplicada, qualitativa e exploratória que se utiliza de pesquisa 
bibliográfica, documental e levantamento de informações com especialistas e entidades com experiência no assunto.

Apesar de ser uma pesquisa essencialmente exploratória, buscou-se, para além da elucidação de uma situação complexa no campo da gestão ambiental, contribuir para identificar um curso de ação pertinente para o trato das questões ambientais das atividades e empreendimentos hidroviários no que tange aos procedimentos.

\subsection{Metodologia da Dissertação}

A metodologia desta pesquisa baseou-se inicialmente em pesquisa bibliográfica e documental acerca do tema a ser desenvolvido, abordando desde as informações gerais do transporte hidroviário interior aos problemas relatados quanto aos licenciamentos das intervenções necessárias à garantia da navegabilidade.

Foram utilizadas diversas fontes de pesquisa, a saber: livros de referência, artigos em periódicos, nacionais e internacionais, teses e dissertações relacionadas à questão. Também foram empregadas informações advindas dos órgãos ambientais, de regulação e do setor de transportes, bem como relatórios e notas técnicas disponíveis nas referidas instituições e com especialistas da área.

Dessa forma, foi possível identificar as características gerais do transporte hidroviário interior e os principais fatores que afetam $o$ aproveitamento do potencial desse transporte no País, com foco nos relacionados à questão ambiental, principalmente, ao procedimento de licenciamento.

Identificou-se ainda possíveis sistemas de classificações para as vias navegáveis interiores. Posteriormente, foram identificadas as intervenções necessárias à garantia da navegabilidade, as principais características das intervenções e classes de intervenções e procedeu-se uma análise crítica dos impactos ambientais potenciais envolvidos.

Finalmente, empenhou-se na construção de uma proposta de abordagem metodológica para o procedimento de licenciamento ambiental das intervenções nas vias navegáveis interiores. Considerando a importância do 
planejamento, identificada ao longo do trabalho, foram também realizadas propostas para a consideração da questão ambiental no planejamento do setor.

As abordagens desenvolvidas devem ser, de algum modo, avaliadas e verificadas. No presente trabalho, essa verificação foi realizada pela submissão das abordagens proposta a um painel de especialistas e pelo teste da abordagem em casos hipotéticos de atividades e empreendimentos hidroviários.

A partir de uma versão das propostas desenvolvidas foram realizadas consultas aos especialistas dos setores hidroviário e ambiental, profissionais de entidades públicas e privadas, órgãos ambientais, empreendedores, consultores, especialistas da área de planejamento ambiental e acadêmicos Foi realizado ainda um encontro, na sala de aula do Programa de Pós Graduação em Tecnologia Ambiental e Recursos Hídricos (PTARH) da Universidade de Brasília - UnB, em que foram discutidos alguns pontos das propostas. Além das consultas, foi elaborado um estudo de caso para verificar a aplicabilidade dos procedimentos apresentados.

Na Figura 3.1, é apresentada a representação que detalha, de forma esquemática, a metodologia utilizada. 


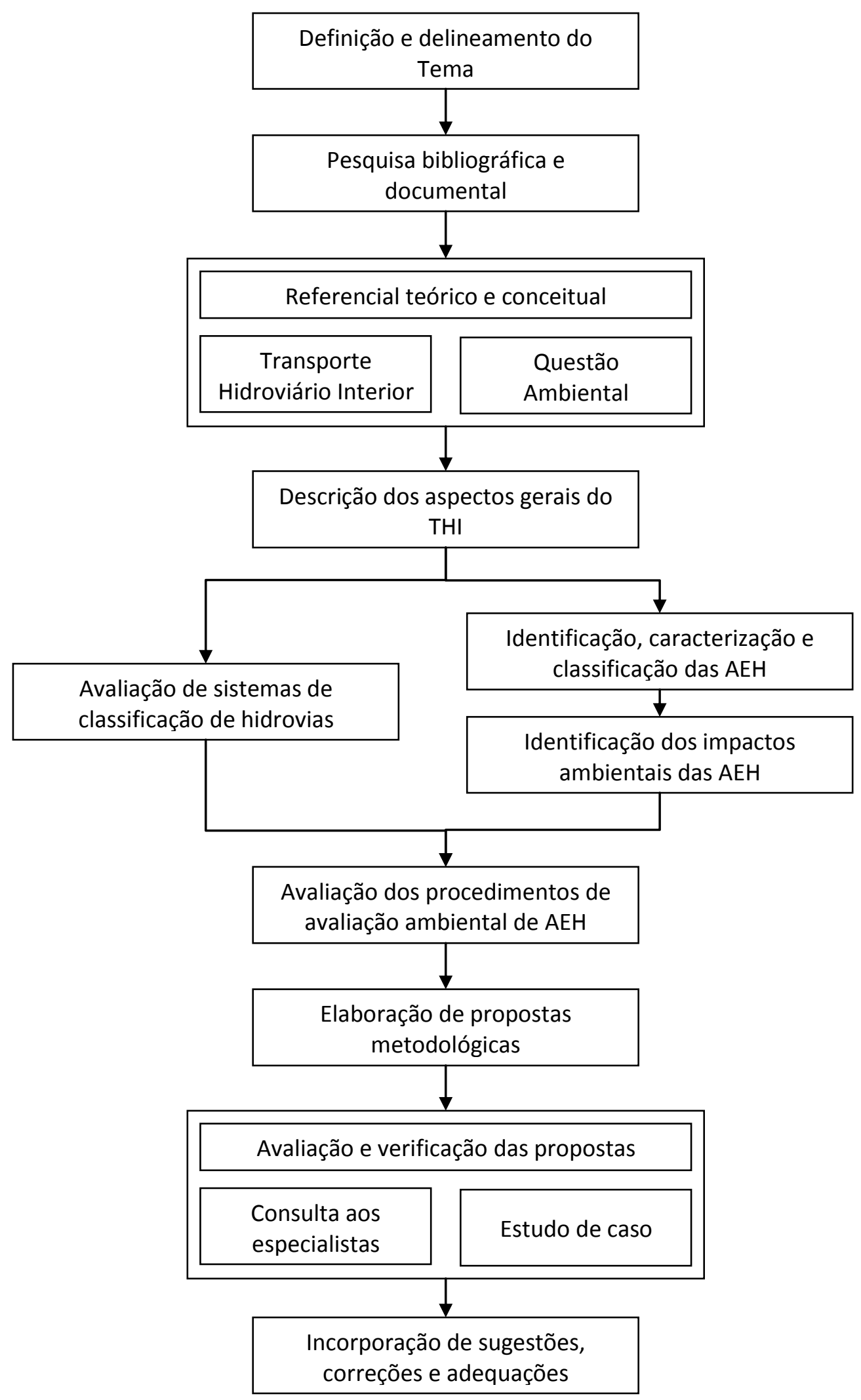

Figura 3.1 - Representação esquemática da metodologia. 


\section{REFERENCIAL TEÓRICO E CONCEITUAL}

\subsection{Transporte Hidroviário Interior}

O Transporte Hidroviário Interior - THI apresenta várias vantagens, tanto econômicas quanto ambientais, em relação aos demais modos de transporte, principalmente para o transporte de grandes volumes de cargas a grandes distâncias. Os benefícios oferecidos pelo transporte hidroviário são amplamente conhecidos e relatados por diversos autores (COSTA, 1998; FILIPPO, 1999; PADOVEZI, 2003; ALMEIDA, 2004; SILVA, 2004; DINIZ, 2007; CARVALHO, 2008; SANTANA, 2008).

O Brasil apresenta um imenso potencial para utilização da navegação fluvial, com 63 mil quilômetros de rios, lagos e lagoas. Desse total, mais de 40 mil quilômetros são potencialmente navegáveis. No entanto, a navegação comercial ocorre em pouco mais de 13 mil quilômetros, com significativa concentração na Amazônia, onde os rios não carecem de maiores investimentos e as populações não dispõem de muitas opções de modos terrestres (BRASIL, 2010a). A importância do THI no Brasil não se restringe às vantagens ambientais ou de custos. Deve-se, também, à falta de vias terrestres que, aliada à abundância de rios, principalmente nas Regiões Norte e CentroOeste, faz desse modo, por vezes, a única opção viável para o escoamento eficiente de cargas e passageiros (DINIZ, 2007).

$\mathrm{Na}$ matriz de transporte brasileira, a participação do modo rodoviário alcança os $52 \%$, o ferroviário $30 \%$, a cabotagem $8 \%$ e o modo dutoviário $5 \%$, enquanto as hidrovias participam apenas com $5 \%$ do total (BRASIL, 2012). Observa-se, uma acentuada diferença entre o Brasil e outros países no aproveitamento das oportunidades e potencialidades desse modo de transporte. Essas diferenças e a apresentação da utilização do THI serão detalhadas adiante.

Visando ao aproveitamento do grande potencial para o transporte hidroviário interior no Brasil, são necessárias intervenções para garantir a navegabilidade e a segurança da navegação. Em muitos casos, as condições naturais precisam ser complementadas por meio de intervenções na 
infraestrutura dos trechos de corpos d'água interiores, de forma a efetivar a navegação.

Diniz (2007) discorre sobre os fatores que influenciam a navegabilidade dos rios, com ênfase para o estudo dos serviços e obras que a propiciam, os impactos ambientais negativos relacionados $e$ as medidas mitigadoras associadas. Esse autor analisou os parâmetros morfológicos, hidráulicos, geométricos, dinâmicos e fixos, que influenciam a navegabilidade dos rios, parâmetros esses essenciais para se determinar as causas de um trecho de rio ser ou não navegável.

Várias restrições existentes em uma hidrovia podem ser eliminadas por intervenções, sejam elas obras, atividades ou serviços. Essas intervenções devem ser objeto de avaliação para verificar suas implicações de ordem econômica e ambiental. Segundo Padovezi (2003), tais intervenções para melhorar as condições de navegabilidade de uma determinada hidrovia dificilmente serão de grande porte. A tendência é que se realizem obras pontuais, localizadas, como dragagens e derrocamentos, que buscarão eliminar certos gargalos, como trechos de baixa profundidade, com afloramentos rochosos ou com excesso de bancos de areia.

A implantação de uma hidrovia ou execução de obras hidroviárias em nosso País sempre foi de responsabilidade do poder público, representado pelos governos federal e estaduais, sendo a operacionalização normalmente realizada por armadores privados. Segundo Azambuja (2005), essas atividades encontram-se associadas a investimentos e custos de manutenção relativamente pequenos, razão pela qual um país que busca seu desenvolvimento não pode abrir mão de uma significativa economia de transporte obtida nesse modo de transporte.

Apesar da necessidade de intervenções nas hidrovias, a fim de desenvolver o transporte hidroviário interior e garantir uma navegação segura, há vários fatores que afetam o desenvolvimento do THI no Brasil, o que provoca morosidade no tratamento das questões relativas às obras hidroviárias.

De acordo com Filippo (1999), diversas são as condicionantes de origem histórica, política, econômica, geográfica, física e gerencial, que fizeram que as hidrovias interiores ficassem relegadas a um segundo plano. Apesar de 
elencadas pelo autor há mais de uma década, esse quadro permanece atual, conforme constatação em outros estudos e manifestações mais recentes.

Diniz (2007) afirmou que o setor de transporte hidroviário interior no Brasil encontra-se estagnado devido, entre outras coisas, à forte concorrência imposta pelo transporte rodoviário e pela falta de investimentos em infraestrutura hidroviária. Segundo o autor, a falta de vontade política e a pouca atenção pública voltada ao modo hidroviário se constatam pelo orçamento reduzido destinado ao setor.

Procurando identificar os entraves ao desenvolvimento do sistema hidroviário, Santana (2008) realizou uma pesquisa exploratória buscando informações técnicas e ambientais, além do arcabouço jurídico dos órgãos intervenientes na gestão do transporte hidroviário. A análise dos organismos intervenientes na gestão ambiental de projetos de hidrovias interiores e legislação aplicável no Brasil também já havia sido realizada por Filippo (1999). Os referidos autores apontaram como principais órgãos intervenientes na gestão do transporte hidroviário, na esfera federal, os seguintes: Ministério dos Transportes; Ministério do Meio Ambiente; Marinha do Brasil (Ministério da Defesa); Ministério das Relações Exteriores; Ministério da Saúde; Ministério do Trabalho e Emprego; Ministério Público Federal; Fundação Nacional do Índio (Ministério da Justiça); Instituto do Patrimônio Histórico e Artístico Nacional (Ministério da Cultura).

Para evitar equívocos, cabe registrar que a expressão, "órgãos intervenientes", utilizada pelos mencionados autores, apresenta conceito diferente da expressão "órgãos intervenientes no processo de licenciamento", cunhada para definir os órgãos que se manifestam no procedimento de licenciamento ambiental, amplamente difundida no meio ambiental. Diferentemente do conceito utilizado pelos autores citados, que se refere aos órgãos com influência na gestão do transporte hidroviário, esse último se refere aos órgãos que têm uma interface formal no processo de licenciamento.

Brasil (2005), mesmo com uma visão restrita apenas aos órgãos vinculados ao Ministério dos Transportes, também alega que a estrutura institucional é complexa, com muitos órgãos e entidades envolvidos (Ministério dos Transportes, DNIT, ANTAQ, Companhias Docas, Administrações Hidroviárias), que já passou por várias reformas, comprometendo, de certa 
forma, a atuação do setor. O relatório conclui que, devido à ausência de sincronização de ações e de uma pauta comum de objetivos, e com tantos órgãos envolvidos, não se consegue promover o real desenvolvimento do setor hidroviário no Brasil.

O Tribunal de Contas da União - TCU realizou, entre fevereiro e junho de 2005, auditoria com o intuito de verificar se as atividades desenvolvidas pelos gestores e executores do Programa Manutenção de Hidrovias teriam sido suficientes para manter as condições de navegabilidade dos principais rios brasileiros. Na verificação de que modo a articulação entre as administrações hidroviárias e os demais órgãos cujas atividades afetam as hidrovias contribui para a efetividade do programa, o relatório concluiu que a falta de planejamento intermodal, a multiplicidade de órgãos envolvidos com o tema e a falta de prioridade do setor hidroviário, em relação ao setor elétrico e ao transporte rodoviário, contribuem para que haja subutilização das hidrovias brasileiras (BRASIL, 2006b).

Ainda, abordando os fatores que afetam o desenvolvimento do setor, até mesmo deficiências no ensino da engenharia já foram citadas. Schappo et al. (2008) assinalaram que a falta de uma adequada abordagem do tema transporte hidroviário nas instituições de ensino superior é algo que tem colocado de lado uma importante ferramenta para o crescimento do País. De acordo com os autores, os futuros profissionais já são induzidos a privilegiar, em seus estudos e projetos, o modo rodoviário em vez de serem encorajados a buscar a alternativa hidroviária ou a ferroviária.

Há, ainda, a falta de gestão integrada dos recursos hídricos, que já era identificada na década de 1990. Filippo (1999) explanou que o Brasil se encontrava em um estágio muito incipiente da gestão integrada dos recursos hídricos e ressaltou que, na concepção dos planos de recursos hídricos, era fundamental levar em consideração os planejamentos setoriais, de todos os setores, inclusive do setor hidroviário.

Cabe destacar, a Lei ำ 9.433, de 08 de janeiro de 1997, instituiu a Política Nacional de Recursos Hídricos, que tem como objetivos: I - assegurar à atual e às futuras gerações a necessária disponibilidade de água, em padrões de qualidade adequados aos respectivos usos; II - a utilização racional e integrada dos recursos hídricos, incluindo o transporte aquaviário, com vistas 
ao desenvolvimento sustentável; III - a prevenção e a defesa contra eventos hidrológicos críticos de origem natural ou decorrentes do uso inadequado dos recursos naturais.

Mais recentemente, o Ministério do Meio Ambiente - MMA também cita a urgência na implementação de uma política integrada de recursos hídricos e a necessidade de se qualificarem e quantificarem critérios e conceitos que traduzam a real importância de uma artéria fluvial, tendo em vista a crescente demanda de desenvolvimento social, econômico e financeiro. Segundo o documento, é inadiável superar uma série de tradições, conceitos e preconceitos que penalizam a utilização das águas de forma múltipla e abrangente (BRASIL, 2006a).

Para a ANA, o instrumento da "manifestação setorial" é um avanço na legislação de recursos hídricos brasileira, pois exige que os diversos usuários integrem suas ações antes da autoridade outorgante emitir sua autorização de uso dos recursos hídricos para uma barragem específica. A Resolução do Conselho Nacional de Recursos Hídricos (CNRH) n 37, de 26 de março de 2004, estabelece diretrizes para outorga de recursos hídricos para a implantação de barragens em corpos de água de domínio dos Estados, do

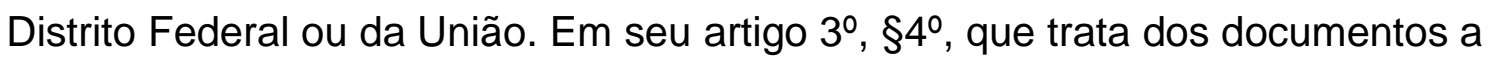
serem apresentados pelo interessado em implantar uma determinada barragem, inclui, quando for o caso, a chamada manifestação setorial. Isso significa que, para as novas barragens, cada setor governamental competente deve emitir um ato administrativo específico acerca daquele novo empreendimento. A Agência registra ainda a necessidade do setor hidroviário estar presente nas discussões dos diversos planos de bacia em que a navegação possui planejamento e apresentar suas propostas (BRASIL, 2005).

Contudo, mesmo após a publicação da Resolução, se observou a execução de vários barramentos, principalmente pelo setor elétrico, sem que tenha sido considerado de forma efetiva o uso múltiplo das águas, mais especificamente no que se refere à navegação. Nesse contexto, o Ministério dos Transportes, elaborou um documento denominado "Diretrizes da Política Nacional de Transporte Hidroviário" em que chama a atenção para a necessidade de equacionar os entraves existentes para a implantação das eclusas prioritárias no País e propõe que sejam tomadas medidas para garantir 
que a operação das hidrelétricas não reduza os níveis de água nos rios a patamares que interrompam a atividade de navegação (BRASIL, 2010a).

Em relação aos barramentos, a Resolução da ANA n 463, de 03 de setembro de 2012, que aprova condicionantes relativas a sistemas de transposição de desnível para a navegação em declarações de reserva de disponibilidade hídrica e outorgas de direito de uso de recursos hídricos de aproveitamentos hidrelétricos em cursos d'água de domínio da União, pode ser considerada um grande avanço normativo. A resolução leva em conta a Lei $n^{\circ}$ 9.433, de 08 de janeiro de 1997, que dispõe no inciso IV do art. $1^{\circ}$ que a gestão dos recursos hídricos deve sempre proporcionar o uso múltiplo das águas, e no art. 13 que toda outorga deverá respeitar a manutenção de condições adequadas ao transporte aquaviário. A resolução determina como condicionantes para as declarações de reserva de disponibilidade hídrica e outorgas de direito de uso de recursos hídricos de aproveitamentos hidrelétricos em cursos d'água de domínio da União navegáveis ou potencialmente navegáveis, a apresentação dos seguintes documentos:

I. Estudo de Concepção e Definição de Alternativas do sistema de transposição de desnível adaptado ao projeto do empreendimento definido no estudo de Viabilidade da UHE, considerando no mínimo uma alternativa no corpo da barragem, e com indicação da alternativa mais adequada sob os aspectos técnico, ambiental e socioeconômico, em conformidade com os requisitos básicos estabelecidos pela ANA;

II. Detalhamento do Sistema de Transposição de Desnível na alternativa definida no inciso anterior.

Conforme se verifica, a Resolução $n^{\circ}$ 463/2012, da ANA, deixou claro que a navegação, atual ou potencial, deve ser considerada no projeto de empreendimentos que utilizam barramentos, devendo para isso ser detalhado o Sistema de Transposição de Desnível, incluindo pelo menos uma alternativa no corpo da barragem, o que, normalmente é mais econômico.

Observa-se, com base no exposto, que fatores de diversas ordens não permitem que o transporte hidroviário brasileiro se desenvolva a contento. Santana (2008) classifica esses fatores em sociais, técnicos, políticos e ambientais. Cabe um destaque a esse último, em que se enquadra o objeto desta pesquisa. 


\subsection{Questão Ambiental}

O tratamento das questões ambientais é um dos grandes desafios a serem observados pelo transporte hidroviário interior no Brasil. Juntamente com o crescimento da demanda por transporte, a preocupação e os cuidados ambientais evoluíram e têm se tornado cada vez mais relevantes.

Diversos estudos já abordaram os aspectos ambientais relacionados aos projetos para transporte hidroviário. As abordagens vão desde a etapa de planejamento do setor hidroviário ao levantamento de impactos ambientais, passando, entre outras, por propostas de metodologias para diferentes áreas dos projetos hidroviários, utilização de Sistemas de Informações Georreferenciadas, proposição de Sistemas de Gestão Ambiental, bem como análises específicas quanto à segurança da navegação.

Conforme Santana (2008) relata, alguns autores abordaram especificamente um ou mais elementos que compõem um sistema hidroviário. Outros abordaram fases específicas do planejamento hidroviário. Também houve aqueles que discorreram sobre fases específicas de planejamento ou gestão ambiental, aplicados a algum elemento específico ou na interação deste com o meio ambiente.

Filippo (1999) levantou os principais aspectos da avaliação de impactos ambientais, com ênfase para projetos de sistemas de transporte hidroviário nos Estados Unidos, na União Europeia e no Brasil, e realizou uma avaliação dos impactos ambientais das fases de implantação e operação de sistemas de transporte hidroviário interior no Brasil. O autor elaborou, ainda, uma original apresentação dos possíveis impactos ambientais decorrentes da implantação e operação de sistemas de transporte hidroviário interior por meio de quadros de análise e matrizes de interação.

No mesmo estudo, o autor abordou a relação entre a hidrovia e a bacia hidrográfica. Ele afirma que a implantação da navegação em bacias hidrográficas que apresentem condições favoráveis para tal, poderia propiciar, inclusive, a preservação ambiental das mesmas, devido, por exemplo, às atividades de controle da erosão do solo e das margens que devem ser 
desenvolvidas, para controle do assoreamento dos canais de navegação dos cursos d'água (FILIPPO, 1999).

Diniz (2007) relacionou entre os diversos tipos de obras e serviços de melhoria da navegabilidade dos rios, os impactos ambientais negativos decorrentes e as medidas mitigadoras associadas a esses impactos. Verificou que os impactos ambientais decorrentes das obras fluviais se manifestam direta e principalmente no meio físico e a partir deles são originados impactos indiretos nos meios biótico e antrópico. $\mathrm{O}$ autor ressaltou que a possibilidade de ocorrência e a magnitude dos impactos associados a essas intervenções dependem das suas características, do modo de execução, dos métodos construtivos e das condições locais.

A caracterização dos elementos de um projeto hidroviário, o levantamento dos aspectos ambientais, identificação das situações de riscos, impactos ambientais e medidas mitigadoras são passos fundamentais para uma embasada proposta de diretrizes para o planejamento e gestão ambiental do transporte comercial de cargas nas hidrovias brasileiras (SANTANA, 2008).

Santana (2008) propôs duas alternativas de implantação de Sistema de Gestão Ambiental, uma que consiste na aplicação de planos e programas ambientais para assuntos e quesitos ambientais de maior relevância, sem se preocupar em certificações ambientais, e outra, que é a aplicação da Norma ISO 14001 para os sistemas hidroviários. Em seu trabalho, o autor sugeriu planos, programas e diretrizes para o planejamento e gestão ambiental de elementos que compõem a infraestrutura do transporte hidroviário interior no Brasil e fez proposições de políticas públicas. Segundo o autor, os processos de planejamento e gestão ambiental das hidrovias brasileiras não existem de maneira global. Assim, ele sugere diretrizes para a elaboração e a criação interministerial de um "Plano Nacional de Gerenciamento Hidroviário" - PNGH.

O trabalho de Santana (2008) foi dividido em elementos, fases, etapas e níveis hierárquicos de gerenciamento para um sistema hidroviário. Os elementos analisados foram vias, veículos, terminais, cargas e controles. $O$ projeto hidroviário foi dividido em etapas de planejamento, implantação, operação, manutenção e desativação/descarte. A partir desses elementos foram identificadas ações, atividades, os aspectos ambientais, os impactos 
ambientais associados a estes, e propostas medidas mitigadoras para minimizar tais impactos ambientais.

Diniz (2007) propôs um Sistema de Gestão Ambiental - SGA para obras fluviais associado a uma ferramenta de informações geográficas. O trabalho incluiu a escolha dos indicadores para cada um dos componentes ambientais presentes na área de influência da obra e padrões a serem estabelecidos. 0 autor desenvolveu um protótipo de Banco de Dados para uma obra fluvial típica de derrocamento num trecho do rio Madeira, sendo para isso utilizado o aplicativo ArcView 3.3.

Silva (2006) utilizou o geoprocessamento, aliado a programas de simulações hidrodinâmicas e modelos digitais do terreno - MDT, como ferramenta para geração, aquisição e análise de parâmetros em infraestrutura hidroviária. Segundo o autor, essas técnicas apesar de apresentarem essências distintas, são complementares. Assim, por meio da conexão de modelos hidrodinâmicos, sistemas de informação geográfica - SIG e modelos digitais de terreno, o autor desenvolveu um procedimento para representar perfis de linha d'água calculados em um ambiente que forneça referenciamento geográfico. Para isso, foram utilizados os programas computacionais HECRAS, ArcView GIS e MDT, bem como algumas extensões e códigos (scripts) para automatizar a transferência dos dados entre os aplicativos.

Santana e Tachibana (2004) apresentam uma caracterização dos elementos de um projeto hidroviário e identificam vantagens, aspectos e impactos ambientais que servem de base para a proposição de metodologias técnicas e ambientais para a elaboração e desenvolvimento de projetos hidroviários, abordando assuntos tais como as vias, as embarcações, as cargas e os terminais. Os autores afirmam que é possível, em termos de desenvolvimento do transporte hidroviário, adotar metodologias de planejamento, de execução e de gestão que sejam tecnicamente viáveis e ecologicamente corretas. O trabalho aponta para a discussão do binômio uso múltiplo das águas versus uso e ocupação do solo e também para a necessidade da incorporação de uma leitura ambiental à postura tecnicista que, tradicionalmente, dominou o setor, em que os terminais multimodais, embarcações fluviais, cargas e vias navegáveis deveriam ser elos táticos entre a logística regional e o desenvolvimento sustentável. 
Goulart e Saito (2012) realizaram uma modelagem qualitativa dos impactos físico-químicos e biológicos da instalação de uma hidrovia na Lagoa Mirim, Rio Grande do Sul. O trabalho procurou mostrar a complexidade do sistema e sua fragilidade frente às intervenções humanas, apontando para a necessidade da discussão sobre a instalação da hidrovia. Segundo os autores, o estudo busca promover uma mediação científica de forma a auxiliar na compreensão da cadeia de causalidade que envolve a instalação da hidrovia.

Carvalho (2008) elaborou uma proposta metodológica para avaliação de projetos de transporte hidroviário interior, com foco no transporte de cargas, considerando os efeitos de um conjunto de diferentes variáveis envolvidas. $\mathrm{O}$ autor propôs uma metodologia geral para avaliação de projetos de transporte hidroviário interior, considerando, simultaneamente, efeitos econômicos, sociais e ambientais. No estudo, a metodologia proposta é aplicada a um projeto de uma hidrovia que se pretende construir na llha de Marajó, no Estado do Pará.

$O$ autor ressalva que os impactos ambientais provocados por atividades e empreendimentos precisam ser mensurados, porém, esses impactos trazem em si grande dificuldade de avaliação monetária. A literatura especializada apresenta uma série de métodos que servem de suporte à valoração monetária de efeitos ambientais, todavia, estes métodos não se mostram adequados a todas as situações em que impactos ambientais se manifestam. Ao se deparar com variáveis não mensuráveis monetariamente ou de mensuração bastante complexa, o autor recorreu a uma técnica complementar que pudesse oferecer um tratamento a essas variáveis. Foi aplicada a técnica de análise multicriterial AHP (Analytic Hierarchy Process) que permite que a importância/preocupação que tomadores de decisão atribuem a cada impacto poderia ser captada (CARVALHO, 2008).

Nos resultados da análise de sensibilidade, Carvalho (2008) identificou que os efeitos ambientais mostraram-se mais sensíveis. Segundo os dados analisados, uma pequena alteração na magnitude da importância conferida a esse conjunto de efeitos poderia alterar a alternativa indicada, referente à construção ou não do empreendimento analisado.

Almeida (2004) fez uma avaliação dos impactos econômicos, sociais e ambientais, quantitativos ou qualitativos, dos projetos de infraestrutura de transporte, segundo a percepção dos usuários. O trabalho buscou captar a 
percepção dos usuários sobre a importância da Hidrovia Tocantins-Araguaia nos principais municípios lindeiros aos rios Araguaia e Tocantins, no Estado do Tocantins, diante dos impactos econômicos, sociais e ambientais que ela possa causar aos municípios onde residem ou atuam.

Silva (2004) busca definir uma estrutura, composta por um sistema e um modelo, que permitiria identificar os impactos ambientais das obras hidroviárias e definir os procedimentos a serem adotados. Segundo o autor, a navegação fluvial é menos impactante ambientalmente, pois a via é de origem natural e não antropogênica, como em alguns outros modos de transporte. Em relação à essa afirmação do referido autor, ressalva-se que essa interação pode, em alguns casos, se transformar em um problema, pois os impactos, principalmente os potenciais, podem apresentar riscos ecológicos maiores.

Tapajós (2002) discute alternativas potenciais de soluções para o delineamento de projetos hidroviários sustentáveis, a partir de uma visão sobre os múltiplos usos e a participação mais direta da sociedade nas tomadas de decisões que envolvem o uso dos recursos hídricos. Esse autor propõe um modelo analítico denominado "Modelo de Indicadores de Sustentabilidade Aplicável a Hidrovias na Amazônia" - MISAHA como gerador de indicadores de sustentabilidade, capazes de auxiliar o delineamento de projetos hidroviários para a Amazônia. O MISAHA é um modelo analítico, baseado no princípio da causalidade que tem como referência conceitual o modelo desenvolvido pela OECD ${ }^{1}$, denominado Pressão-Estado-Resposta (P-E-R).

Chamorro (2009) analisou as transformações do espaço regional na Microrregião Geográfica do Baixo Pantanal, decorrentes do processo de modernização da Hidrovia do Rio Paraguai, promovida pela política pública de transporte em Mato Grosso do Sul, no período de 1999 a 2006. O autor sugeriu, entre outras recomendações, que fossem criadas e aplicadas leis que fiscalizem e regulem a construção das barcaças empregadas pelas empresas que exploram o setor, obrigando-as que utilizem barcaças que se adaptem aos diferentes trechos do rio e não o contrário, fazer com que o rio se adapte às barcaças.

\footnotetext{
${ }^{1}$ OECD - The Organisation for Economic Co-operation and Development
} 
O mesmo entendimento, de adaptação das barcaças aos rios, foi objeto de outro estudo mais aprofundado em relação a essa abordagem. Padovezi (2003) propôs um modelo de procedimentos de projetos de comboios fluviais adaptados às condições existentes das vias navegáveis, a partir de uma visão ampliada da necessidade de obtenção de menores custos de transporte, com níveis adequados de segurança e de respeito ao meio ambiente. A elaboração do modelo foi orientada por uma análise das inter-relações técnicas entre hidrovias e embarcações, assim como dos condicionantes e implicações do conceito de embarcações adaptadas às vias navegáveis.

Segundo Padovezi (2003), à definição de embarcações adaptadas às vias, em busca de uma maior eficiência com maior segurança do transporte de cargas, deve ser agregada a visão de que a adaptação da via também deve significar uma menor agressão ao meio ambiente. Afinal, é indispensável que a embarcação fluvial seja considerada como merecedora de projetos especiais que agreguem os resultados da evolução tecnológica, deixando de ser vista como algo resolvido, estático, que não é variável importante do problema de transporte. Na prática, verifica-se, em vários casos, que não se dá a importância devida à qualidade final da embarcação e, em consequência, durante décadas, transporta-se com penalizações de eficiência.

Garaventta (2008) elaborou uma avaliação dos riscos envolvidos na atividade de transporte hidroviário dos óleos combustível, diesel e leve de reciclo, aplicado à Lagoa dos Patos, de acordo com ferramentas de análise de riscos e simulação dos cenários. O estudo apontou a necessidade de aprofundar a discussão dos aspectos de segurança da navegação, principalmente no tocante ao transporte de cargas perigosas, pois, embora episódios de contaminação ambiental decorrentes do vazamento de produtos petrolíferos não sejam frequentes, a magnitude e severidade das consequências de acidentes à população, à economia e aos recursos naturais fazem deles os mais visíveis e preocupantes para a opinião pública.

Por sua vez, Ferreira (2000) examinou os acidentes registrados na hidrovia Tietê-Paraná, identificando os mais importantes e suas respectivas causas, com a finalidade de propor formas de reduzir a probabilidade de ocorrência de tais acidentes. O trabalho contribui para que se compreendam melhor os aspectos mais relevantes de acidentes ocorridos no transporte 
hidroviário. De acordo com o autor, dever-se-ia unir esforços para se alcançar um embasamento menos especulativo e mais científico-experimental que venha a contribuir, não somente para a resolução dos problemas presentes hoje na hidrovia, mas, sobretudo, para a formação de uma cultura hidroviária mais científica e profissional.

A questão da segurança na navegação também foi abordada por Bastos (2006), que trabalhou a questão dos acidentes no trânsito fluvial com pequenas embarcações, em especial, do escalpelamento provocado pelos eixos de motores de barcos. De acordo com o autor, esse tipo de acidente, embora trágico, é comum na região amazônica e ocorre principalmente com a população ribeirinha, que depende intimamente do transporte hidroviário para exercer praticamente todas as suas atividades cotidianas. $O$ estudo se restringe ao Estado do Pará, mais especificamente à área da região metropolitana de Belém, bem como outros municípios paraenses que possuem relações por via fluvial com a capital, mas suas conclusões podem ser estendidas para outras situações na Região Amazônica.

Conforme já apontado, a Região Amazônica apresenta uma deficiência de infraestrutura viária terrestre que, aliada ao enorme potencial hídrico, faz do modo hidroviário, por vezes, a única opção viável para o escoamento eficiente de cargas e passageiros. $O$ transporte hidroviário nessa região foi objeto de vários estudos.

A região Amazônica é composta em maior parte de seu espaço territorial por rios navegáveis, de grande volume de água. O transporte fluvial é utilizado de maneira intensa pela sua população, para usos comerciais e domésticos. Mesmo diante desta realidade, o transporte fluvial não é priorizado como um dos principais focos de investimentos socioeconômicos (BASTOS, 2006).

De acordo com Tapajós (2002), há um antagonismo que pode ser caracterizado da seguinte forma: i) de um lado, uma hidrovia é considerada a infraestrutura de transporte que causa os menores impactos ao meio ambiente, as condições físicas da Amazônia Brasileira são as mais adequadas ao uso de hidrovias, o transporte fluvial é considerado de incontestável economia, não existem dificuldades técnicas e financeiras para execução das obras hidráulicas e ii) por outro lado, existem restrições sistemáticas à implantação de projetos hidroviários. Para o autor, é necessário entender as motivações desse 
confronto, para uma região reconhecidamente de características fluviais e com um transporte que já faz uso dos rios como malha hidroviária natural. Essas restrições apontadas pelo autor ocorrem, geralmente, pelo posicionamento contrário às hidrovias por alguns grupos de interesse.

O Ministério do Meio Ambienta - MMA ressalta que, entre os modos de movimentação de cargas, o transporte fluvial é o que mais interage com o meio, uma vez que seu suporte operacional é o curso de água que se constitui, também, no vínculo insubstituível para o desenvolvimento. Isso leva a inferir que a hidrovia pode ser considerada naturalmente sinérgica com a natureza. $\mathrm{A}$ utilização adequada das hidrovias pode criar condições propícias para 0 desenvolvimento sustentável, ou seja, um desenvolvimento ciclicamente alimentado pelas suas próprias economias de escala e perfeitamente balanceado com o meio ambiente (BRASIL, 2006a). O documento do MMA considera que a revitalização dos rios brasileiros poderá trazer, em seu bojo, a navegação e o desenvolvimento regional, o que pode ser observado no trecho selecionado a seguir:

Pode parecer paradoxal, mas o vínculo entre navegação fluvial e meio-ambiente pode ser positivo, já que, a navegação fluvial só tem condições de sucesso em rios conservados ou revitalizados ambientalmente, pois depende de vazões e níveis de água, de margens protegidas por matas ciliares, o que implica na diminuição do assoreamento do corpo d'água redução de bancos de areia por efeito de erosões, empecilhos estes que obstam o fortalecimento da navegação e demais usos das águas (BRASIL, 2006a).

Segundo o Caderno Setorial de Recursos Hídricos (BRASIL, 2006a), muitos dos rios brasileiros se encontram em processo progressivo de degradação em virtude da ocupação das margens, do desflorestamento ciliar e de outras intervenções. Ainda de acordo com o estudo, a melhor forma de conter e reverter o progressivo processo de degradação da maioria dos rios brasileiros é o estímulo ao desenvolvimento sustentável em que se inclui a navegação como parceira e controladora.

Azambuja (2005) oferece uma visão estratégica da importância da navegação fluvial praticada em vias interiores, focando na região da Lagoa Mirim, localizada no extremo sul do Brasil. O estudo analisa os aspectos de carga, obras estruturais (terminais e vias) e embarcações necessárias, bem como, a alternativa de uso de contêineres para o transporte de "carga geral" e apresenta um conjunto de soluções, que, de acordo com o autor, se constitui 
em uma proposta integrada cuja aplicação pode fazer diferença significativa para a viabilização hidroviária. De acordo com o autor, a sociedade brasileira deverá encontrar um denominador comum que contemple o convívio dos interesses de transporte com os de preservação do meio ambiente.

Como se pode observar, as questões ambientais dos empreendimentos hidroviários vêm sendo trabalhadas há algum tempo no Brasil. Entretanto, o processo de licenciamento ambiental de intervenções relacionadas ao transporte hidroviário continua sendo uma questão controversa, que tem provocado, inclusive, diversas paralisações devido a processos judiciais.

O licenciamento de atividades efetiva ou potencialmente poluidoras constitui um instrumento para a execução da Política Nacional do Meio Ambiente - PNMA, incorporado à legislação brasileira pela Lei no 6.938, de 31 de agosto de 1981. É o procedimento administrativo pelo qual o órgão ambiental competente licencia a localização, instalação, ampliação e a operação de empreendimentos e atividades utilizadoras de recursos ambientais, consideradas efetiva ou potencialmente poluidoras ou daquelas que, sob qualquer forma, possam causar degradação ambiental, considerando as disposições legais e regulamentares e as normas técnicas aplicáveis ao caso.

As principais diretrizes para a execução do licenciamento ambiental estão expressas na Lei 6.938/81 e nas Resoluções CONAMA no 001/86 e no 237/97. Além dessas, recentemente, foi publicada a Lei Complementar no 140/2011, que discorre sobre a competência estadual e federal para 0 licenciamento, tendo como fundamento a localização do empreendimento.

Problemas no licenciamento ambiental são histórica e rotineiramente apontados com um dos principais fatores que afetam o transporte hidroviário interior. As hidrovias Paraná-Paraguai, Tocantins-Araguaia, Teles PiresTapajós e o tramo Sul da Tietê-Paraná já tiveram processos de licenciamento ambiental interrompidos por ordem judicial (COSTA, 1998).

Carvalho (2008) cita, ainda, problemas no licenciamento do projeto de uma hidrovia que se pretende construir na llha de Marajó, no Estado do Pará. Segundo o autor, em 1998, o Ministério Público Federal impetrou, na Justiça, uma ação civil pública contra a obra, sob a alegação de que adviriam impactos 
ambientais de sua execução. Desde então, não houve avanço no desenvolvimento do projeto.

O TCU realizou uma auditoria, em 2005, no Programa de Manutenção de Hidrovias e, entre outros aspectos, concluiu que há dificuldades para aprovação de licenças ambientais, principalmente pela falta de definição clara do objeto de licenciamento. Também, foi identificada deficiência de acompanhamento dos serviços de monitoramento ambiental solicitados pelo IBAMA às Administrações Hidroviárias. Por fim, verificou-se que não há atividades de educação ambiental para a compreensão dos impactos causados pelas hidrovias. Segundo o relatório do Tribunal, no processo de licenciamento das hidrovias, as principais razões para a demora na aprovação de licenças ambientais são a falta de definição do objeto de licenciamento ambiental e a dificuldade de conciliar os interesses econômicos e administrativos com os interesses ambientais (BRASIL, 2006b).

Filippo (1999) realizou uma análise dos principais entraves no processo de licenciamento ambiental de projetos de hidrovias interiores no Brasil. De acordo com o autor, esses entraves são decorrentes, principalmente, dos motivos a seguir relacionados, dos quais a maioria ainda permanece atual:

- Desconhecimento dos verdadeiros impactos oriundos das atividades de implantação e operação de hidrovias interiores, em virtude do pouco emprego desse modo no País;

- Falta de subsídios aos órgãos de pesquisas no campo da engenharia portuária, costeira e fluvial, para ampliação dos conhecimentos e desenvolvimento de novas tecnologias aplicáveis ao transporte hidroviário interior;

- Estrutura limitada dos órgãos ambientais competentes para análise dos estudos ambientais;

- Apresentação de estudos ambientais deficientes, que não atendem à legislação vigente no País e às exigências dos órgãos ambientais;

- Pouca experiência no campo da gestão integrada dos recursos hídricos, o que dificulta as ações e entendimentos com os demais órgãos envolvidos; 
- Interesses contrários à implantação das hidrovias por parte de entidades ambientalistas, de determinados grupos da sociedade civil organizada e de outros transportadores modais, como rodoviários e ferroviários.

Filippo (1999) mostra, ainda, a preocupação em relação à paralisação dos empreendimentos hidroviários, conforme trecho replicado a seguir.

\begin{abstract}
A paralisação da implantação ou mesmo da operação das atividades de um empreendimento, fato que tem acontecido com grande frequência nos projetos de desenvolvimento de hidrovias interiores no Brasil, compromete a gestão financeira dos mesmos e causa incerteza e desconfiança quanto aos reais benefícios que os mesmos podem trazer para a sociedade e para o País (FILIPPO, 1999).
\end{abstract}

$\mathrm{Na}$ pesquisa realizada por Almeida (2004), vários entrevistados assinalaram que o lento processo de implantação comprometia a inserção da hidrovia em projetos institucionais ou empresariais e causava descrença sobre sua consolidação.

Outro ponto que tem influenciado os processos de licenciamento é que as propostas de projetos hidroviários têm recebido, sistematicamente, fortes restrições por parte de organizações da sociedade civil (TAPAJÓS, 2002; AZAMBUJA, 2005; SANTANA, 2008). Isso se torna ainda mais flagrante quando o processo de tomada de decisão não incorpora a participação dos diversos setores da sociedade. $O$ aperfeiçoamento dos mecanismos de participação da sociedade nas tomadas de decisão de políticas, planos, programas e projetos diminuiria muito esse problema. Observa-se tal análise no trecho a seguir, extraído de Filippo (1999).

\begin{abstract}
Outro aspecto importante corresponde ao grau de participação da sociedade de uma maneira geral na tomada de decisão para implantação de empreendimentos de transportes ou de outros que, de alguma forma, provocam efeitos nos distintos setores da sociedade. Diferentemente do que ocorre em países como Estados Unidos, onde a participação popular ocorre de maneira programada, ampla e efetiva nas várias etapas do planejamento e do licenciamento dos projetos, no Brasil, esta participação é bastante restrita e muitas vezes tardia dentro do processo de planejamento e concepção dos mesmos. Este aspecto propicia o surgimento de conflitos posteriores provocados pelo descontentamento de determinados grupos da sociedade que são afetados, direta ou indiretamente, pela implantação dos empreendimentos. Ao contrário, com a participação prévia dos mesmos, desde a fase de planejamento, poderiam ser levantados todos os possíveis problemas que, no futuro, serão motivos para causar inclusive, a paralisação da implantação de um empreendimento. (FILIPPO, 1999)
\end{abstract}

Goulart e Saito (2012) também consideram fundamental que, nesse tipo de discussão, permita-se a ampla participação de todos os segmentos sociais 
afetados, positivamente e negativamente, pelo empreendimento. Os autores ressalvam que essa participação deve-se realizar com base em um arcabouço teórico-científico que permita que cada segmento compreenda a complexidade dos fatores envolvidos e possa decidir com consciência sobre a instalação da hidrovia.

No Brasil, os processos para a tomada de decisão sobre investimentos e estratégias de ações que integram políticas, planos e programas de Governo, ainda carecem de ações e legislações específicas, sob o ponto de vista de análises ambientais em escalas mais abrangentes e em níveis estratégicos. Essas análises são fundamentais para a identificação dos conflitos ambientais ainda nos estágios iniciais do planejamento para o desenvolvimento de regiões e implantação de eixos estratégicos de transporte, principalmente em se tratando de projetos que influenciem áreas extensas, com características ambientais diversas.

Dessa forma, como resultado da deficiência no planejamento, alguns atores persistem em levar discussões de políticas públicas para o âmbito do processo de licenciamento ambiental, desvirtuando assim, tanto a formulação da política como o próprio processo de licenciamento.

Ainda assim, apesar de se revelar um problema significativo, nenhum estudo recente aborda os detalhes da avaliação ambiental dos empreendimentos hidroviários, em especial o licenciamento ambiental. As análises sobre o licenciamento dessa tipologia encontradas na literatura são, em geral, utilizadas como pano de fundo dos estudos e não são objetos de detalhamentos. Os estudos que abordam 0 licenciamento desses empreendimentos, o fazem de forma mais geral, não entram nas nuances do processo de licenciamento, não abordam claramente o objeto de análise e, poucas vezes, vão além de uma descrição superficial do rito ordinário de licenciamento. 


\section{TRANSPORTE HIDROVIÁRIO INTERIOR}

\subsection{Navegação}

O conceito sobre navegação permite entender o trajeto habitual feito por uma "nave", transportando cargas ou passageiros sobre a água. O termo "navegação" engloba toda a técnica do transporte hidroviário, incluindo o aproveitamento, adaptação e construção das vias navegáveis, bem como a construção e condução das embarcações (SILVA, 2006; SANTANA, 2008). O transporte hidroviário compreende a navegação de longo curso, cabotagem e navegação interior.

Habitualmente chamada de transporte marítimo internacional, a navegação de longo curso é a efetuada por navios mercantes entre portos de diferentes países. As vias de navegação marítima são os mares e os oceanos e só haverá problema para a navegação nas áreas de pequena profundidade, próximo à costa.

Cabe destacar a preponderância do transporte marítimo no comércio internacional. De acordo com o Sistema de Análise das Informações de Comércio Exterior via Internet (ALICEWeb)2 , do Ministério do Desenvolvimento, Indústria e Comércio Exterior - MDIC, passam pelo portos brasileiros cerca de 95\% da quantidade de mercadorias brasileiras exportadas.

Já o transporte de cabotagem é aquele realizado entre portos de um mesmo país, ou seja, as cargas têm como origem e destino o próprio mercado interno, utilizando a via marítima ou vias navegáveis interiores. O termo cabotagem é derivado do nome de família do navegador veneziano do século XVI Sebastião Caboto. Existe ainda o termo "cabotagem internacional", que é utilizado frequentemente para designar a navegação costeira envolvendo dois ou mais países.

O transporte hidroviário interior é o realizado através de rios, lagos, lagoas, baías, angras, enseadas e canais de um país, que correspondem às possíveis vias da navegação fluvial. Além do conjunto de tipos de vias, o

\footnotetext{
${ }^{2}$ ALICE WEB. Sistema de Análise das Informações de Comércio Exterior. Ministério do Desenvolvimento, Indústria e Comércio Exterior - MDIC. Disponível em: <http://aliceweb.desenvolvimento.gov.br/>. Acesso em 15/12/2011.
} 
transporte hidroviário interior compreende: embarcações fluviais, terminais, instalações de construção e reparo naval, suporte tecnológico inerente, recursos humanos empregados no setor e organizações envolvidas (FILIPPO, 1999).

\subsection{Transporte Hidroviário Interior}

$\mathrm{Na}$ história da humanidade, o transporte por água pode ser considerado como o mais antigo. Muito antes da descoberta da roda, o homem já se deslocava sobre a água com o emprego de materiais flutuantes.

Durante milhares de anos, os rios e lagos foram estradas naturais por onde as populações, fixadas junto às suas margens, escoaram sua produção, ou mesmo deslocaram-se para penetrar em novas terras, com o intuito de colonizá-las. Assim, os rios sempre se constituíram como vias de "penetração e transporte" e, dessa forma, as cidades se estabeleciam em suas margens, ao longo das quais se desenvolveram as grandes civilizações (FILIPPO, 1999; SILVA, 2004; SANTANA, 2008).

Os principais usos da água dos rios sempre foram o consumo humano, a dessedentação de animais e a irrigação, mas é também da época das primeiras civilizações que se tem notícia dos primeiros transportes de carga e pessoas, com embarcações movidas a remo ou vela (FILIPPO, 1999; SILVA, 2004; SANTANA, 2008).

Existem aproximadamente 450 mil quilômetros de vias navegáveis interiores no mundo, porém, somente 190 mil quilômetros são efetivamente utilizados para o transporte de carga, com destaque para os Estados Unidos, a região da ex-União Soviética e a Europa Ocidental (FILIPPO, 1999). A Figura 5.1 apresenta a extensão dos maiores sistemas de navegação interior no mundo. 


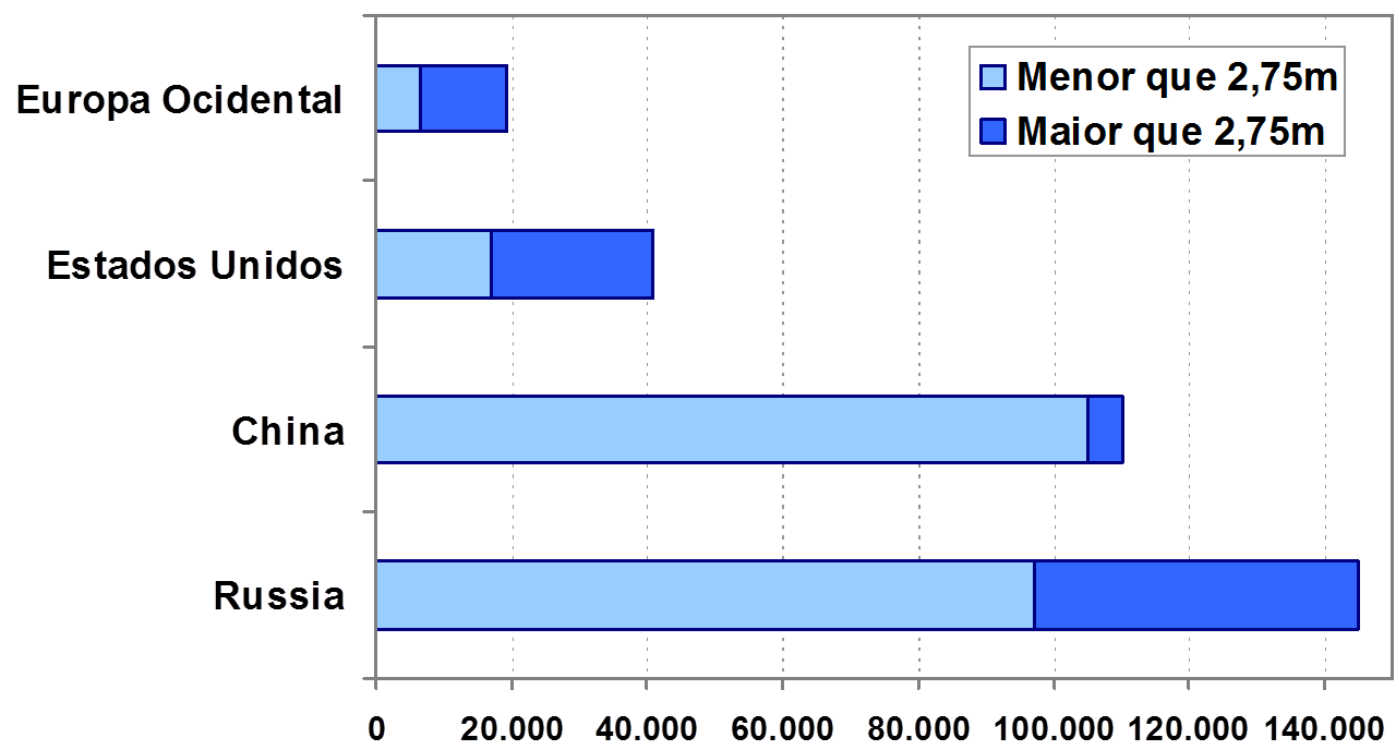

Figura 5.1 - Extensão, em quilômetros $(\mathrm{km})$, dos principais sistemas de navegação (Europa Ocidental, Estados Unidos, China e Rússia), divididos em calados maiores e menores que $2,75 \mathrm{~m}$.

Fonte: World Bank, Ports, Maritime \& Logistics: Inland Water Transportation (IWT) Development (2000) apud RODRIGUE (2013)

Conforme se verifica na Figura 5.1, a Rússia tem o mais extenso sistema fluvial do mundo, mas o inverno rigoroso impede o uso comercial eficaz da maior parte dos cursos de água. Embora o sistema fluvial chinês seja extenso, apenas uma pequena parte dele, 5.000 quilômetros, tem profundidade adequada para acomodar navios fluviais de mais de 500 toneladas com calado superior a 2,75 metros. Os sistemas de navegação fluvial dos Estados Unidos e da Europa Ocidental são de menor escala, mas capazes de suportar maiores navios fluviais na maioria de seus cursos de água. Cerca de $90 \%$ de toda a carga transportada nas vias navegáveis interiores do mundo utiliza o sistema dos Rios Mississipi e Ohio, principalmente por meio de transporte a granel em barcaças. Portanto, não é necessariamente o comprimento do sistema hidroviário que importa, mas as regiões e mercados comerciais que eles atendem ${ }^{3}$.

Na Europa e nos Estados Unidos, o modo hidroviário integra a malha de transportes do continente e do país, respectivamente, operando de forma interligada com os demais modos. Nesses locais, a hidrovia é uma das vertentes do aproveitamento múltiplo das águas. Embora as obras fluviais

\footnotetext{
${ }^{3}$ Tradução do texto "Length of the Major Inland Waterway Systems, 2000" - disponível em <http://people.hofstra.edu/geotrans/eng/ch3en/conc3en/lengthwaterways.html>
} 
tenham como consequência também a navegação, o objetivo principal é o desenvolvimento regional, a ampliação das áreas agriculturáveis, o controle das cheias, a estabilização do leito e a utilização racional e harmoniosa das águas (BRASIL, 2006a).

O documento elaborado pelo Ministério do Meio Ambiente relaciona alguns pontos referentes à navegação fluvial no mundo para reflexão (BRASIL, 2006a). Esses pontos são replicados a seguir.

- Hidrovias estão integradas a uma vasta malha de transportes, cujas modalidades não competem entre si. A intermodalidade é estimulada pelos organismos governamentais;

- Hidrovias encontram-se relacionadas à utilização múltipla dos recursos hídricos cujo aproveitamento tem por objetivo o desenvolvimento regional;

- Hidrovias congregam polos industriais e agrícolas em suas margens e área de influência direta e visam reduzir custos de exportação e do mercado interno;

- O esforço governamental e privado é no sentido de construir ou reformar hidrovias para admitirem comboios de elevada capacidade de carga e segurança/garantia de transporte;

- Terminais hidroviários operam com elevadas cadências de embarque e desembarque transferindo cargas para as unidades de armazenagem e interface de forma a aliviar as operações portuárias marítimas;

- Algumas bacias hidrográficas estratégicas para o desenvolvimento do país são planejadas por agências voltadas ao desenvolvimento regional, nas quais as hidrovias encontram-se vinculadas;

- As hidrovias americanas encontram-se sob responsabilidade do Exército;

- As maiores rendas per capita do interior americano são encontradas nas cidades marginais aos rios navegáveis;

- Os rios em estado natural sofrem intervenções de contenção de margens e estabilização do curso fluvial no sentido de minorar a degradação ambiental e geomorfológica provocada pela ocupação antrópica e carregamento sólido do rio; 
- Os fundamentos ambientais que norteiam as obras hidroviárias encontram-se vinculados ao desenvolvimento social e econômico das populações da bacia.

- Os conceitos ambientais fundamentam-se na revitalização do curso fluvial adaptando-o ao desenvolvimento sustentado;

- Na Europa e Estados Unidos, a navegação fluvial moderniza-se de forma constante e progressiva visando atender a movimentação de cargas em larga escala. São mais de 2,65 bilhões de toneladas anuais;

- Na Europa, os investimentos em hidrovias são amortizados a taxas anuais de retorno da ordem de $3 \%$ visando uma "viabilização social" do empreendimento, como ocorre na Bélgica".

\subsection{Transporte Hidroviário Interior no Brasil}

O transporte hidroviário já ocupou lugar de destaque e prioridade nas atividades econômicas do País, quando os cursos aquáticos eram preponderantes na condução das relações comerciais. Os rios, de forma geral, transformaram-se em eixos econômicos que viabilizaram, em algumas regiões brasileiras, a multiplicação dos núcleos urbanos às suas margens e permitiram que, através de seus cursos naturais, fosse desbravado o interior do Brasil, ampliando suas fronteiras e estabelecendo seus limites (BASTOS, 2006).

Desde a época da conquista e expansão do território brasileiro até a primeira metade do século $X X$ a navegação fluvial brasileira colaborou na consolidação das fronteiras e da integração do País, fixando populações e descobrindo riquezas e oportunidades nos locais mais afastados do interior brasileiro (BRASIL, 2006a). Até aquele momento, os planos de infraestrutura de transportes não continham projetos de desenvolvimento do modo rodoviário, dando prioridade às vias férreas e à navegação fluvial (CHAMORRO, 2009).

A navegação interior somente foi utilizada como política pública de transporte durante o período colonial (1500-1822) e do Império (1822-1889) (BRASIL, 2007a). No final do século XIX, a prioridade foi dada ao transporte ferroviário, justificada à época, pela maior velocidade e capacidade de carga do trem em relação às embarcações (SANTANA, 2008). 
O documento "Breve Histórico sobre a Evolução do Planejamento Nacional de Transportes" ${ }^{4}$, do Departamento Nacional de Infraestrutura de Transportes - DNIT, relata a evolução dos planos nacionais de viação e os principais fatos históricos que interferiram na política de transportes do País. $O$ Quadro 5.1 apresenta uma compilação dos planos elaborados no século XIX e suas principais características.

\footnotetext{
${ }^{4}$ Breve Histórico sobre a Evolução do Planejamento Nacional de Transportes. Departamento Nacional de Infraestrutura de Transportes - DNIT. Disponível em http://www.dnit.gov.br/planejamento-e-pesquisa/historico-do-planejamento-de-transportes.
} 
Quadro 5.1 - Principais planos nacionais de viação no século XIX e suas características.

\begin{tabular}{|c|c|}
\hline Plano & Características \\
\hline Plano Rebelo (1838) & $\begin{array}{l}\text { Idealizava a construção de três estradas reais. } \\
\text { Apesar de irreal para a época foi a primeira contribuição teórica } \\
\text { para a execução de uma política viária de integração nacional. }\end{array}$ \\
\hline Plano Moraes (1869) & $\begin{array}{l}\text { Denominado "Navegação Interior no Brasil“, foi apresentado ao } \\
\text { Governo Imperial, em 1869, e elaborado pelo engenheiro militar } \\
\text { Eduardo José de Moraes e ficou conhecido como "Plano Moraes". } \\
\text { Trazia um esboço de rede geral de vias navegáveis e inferia que } \\
\text { com poucas obras poderia estabelecer uma ampla rede de } \\
\text { comunicação fluvial ligando os portos mais longínquos do País. } \\
\text { Propôs a interligação de todas as bacias hidrográficas do País: a } \\
\text { Amazônica com a Bacia do Prata, essa com a do rio São Francisco } \\
\text { e, finalmente, a ligação com a bacia do rio Paranaíba e seus } \\
\text { afluentes. } \\
\text { Previa a integração do sistema fluvial com as ferrovias e a } \\
\text { navegação de cabotagem, por meio da construção de três grandes } \\
\text { estradas de ferro conectando os portos do Rio de Janeiro, Salvador } \\
\text { e Recife com as bacias dos rios mencionados. }\end{array}$ \\
\hline Plano Queiroz (1874) & $\begin{array}{l}\text { Considerou o aproveitamento do Rio São Francisco, a organização } \\
\text { de redes de comunicações ferroviárias, e no aprimoramento de } \\
\text { 1882, ao estabelecimento de uma artéria central Leste-Oeste. }\end{array}$ \\
\hline Plano Rebouças (1874) & $\begin{array}{l}\text { Considerou o Brasil com a forma triangular, com a base no Rio } \\
\text { Amazonas e tendo com vértices o litoral e a fronteira. } \\
\text { Propunha linhas ferroviárias transversais paralelas à base na } \\
\text { direção Leste-Oeste e linhas auxiliares ligando às principais } \\
\text { transversais. }\end{array}$ \\
\hline Plano Bicalho (1881) & $\begin{array}{l}\text { Projeto denominado Rede de Comunicações, elaborado pelo } \\
\text { engenheiro Honório Bicalho. } \\
\text { Deu ênfase às ferrovias e navegação fluvial. } \\
\text { Consolidava trechos naturalmente navegáveis devidamente } \\
\text { conectados às ferrovias. } \\
\text { Afirmava que "o primeiro meio que mais naturalmente se apresenta } \\
\text { para vencer as grandes distâncias que quase isolam as diversas } \\
\text { províncias do império é utilizar a navegabilidade natural e } \\
\text { aperfeiçoada dos rios" }\end{array}$ \\
\hline $\begin{array}{l}\text { Plano Geral de Viação } \\
(1886)\end{array}$ & $\begin{array}{l}\text { Propunha a construção de novas ferrovias de modo a permitir o } \\
\text { acesso ao interior do País com a interligação dos modos fluvial e } \\
\text { ferroviário. }\end{array}$ \\
\hline $\begin{array}{l}\text { Plano da Comissão de } \\
1890\end{array}$ & $\begin{array}{l}\text { Estabelecia as competências federais e estaduais no transporte } \\
\text { ferroviário e fluvial, prevendo futuras ligações desses modos. } \\
\text { Consolidava trechos naturalmente navegáveis devidamente } \\
\text { conectados às ferrovias }\end{array}$ \\
\hline
\end{tabular}

Fonte: Adaptação de "Breve Histórico sobre a Evolução do Planejamento Nacional de Transportes" (2013a) 
Apesar desses planos, até o início do século $X X$, não foi possível implantar uma rede de transporte nacional eficiente e integrada entre os modos ferroviários e hidroviários. Almeida (2001) cita, dentre outras causas para o não crescimento desses modos, a ausência de demanda no mercado interno e a incapacidade técnica em gerir tais empreendimentos.

Na década de 1920, iniciou-se a campanha em prol das rodovias por meio da criação de diversas associações particulares destinadas ao estudo e divulgação do rodoviarismo. O primeiro grande impulso para o desenvolvimento do rodoviarismo brasileiro ocorreu durante o Governo de Washington Luís (1926-1930). Em meados da década de 1930 e 1940, o Brasil investiu na criação de órgãos e departamentos para o transporte rodoviário. Era o começo de uma nova e duradoura era dessa modalidade de transporte (BASTOS, 2006).

O transporte rodoviário assumiu a prioridade por ser um modo mais rápido, pela sua grande capacidade de suplantar grandes dificuldades em áreas de difícil topografia e também pela vantagem de levar a carga de porta a porta.

Não tendo como enfrentar a forte concorrência praticada pelas ferrovias e rodovias, a navegação interior foi relegada a um segundo plano, perdendo investimentos em sua infraestrutura e ficando limitada a um desempenho muito abaixo de seu potencial.

A Constituição de 1934 ainda priorizava a navegação, mas já preceituava o estabelecimento de um plano nacional ferroviário e de estradas de rodagem além de propor a regulamentação do tráfego rodoviário interestadual.

O Plano Geral Nacional de Viação de 1934, criado no Governo Getúlio Vargas (1930-1937), foi o primeiro projeto nacional para os transportes aprovado oficialmente, apesar de ainda ter uma grande influência dos anteriores. Era de natureza multimodal, mas a prioridade conferida pelo Governo à modalidade rodoviária já começava a se revelar.

Em 1947, tentou-se a criação do Plano Nacional de Viação Fluvial, de autoria do Coronel Jaguaribe de Matos, que declarava que "o progresso real dos sistemas rodoviário e ferroviário depende do progresso do sistema fluvial”. 
A implantação, em 1957, da indústria automobilística no País foi o passo definitivo para a consolidação do rodoviário como modo mais utilizado, que atualmente representa mais de $50 \%$ da matriz de transportes brasileira.

Em 1973, por meio da Lei ํㅜ 5.917, foi concebido e aprovado o atual Plano Nacional de Viação - PNV. Nele estão conceituados os sistemas nacionais rodoviários, ferroviários, aquaviários, portuários e aeroviários.

Em abril de 2007, foi lançado o Plano Nacional de Logística e Transporte - PNLT, fruto da retomada do planejamento de médio e longo prazo para o setor, que serviu de embasamento para a formulação dos Planos Plurianuais para os horizontes de 2008 a 2011 (PPA 2008-2011) e de 2012 a 2015 (PPA 2012-2015).

O PNLT reconhece a necessidade de efetiva mudança, com melhor equilíbrio, na atual matriz de transportes de cargas do País, na medida em que a otimização e a racionalização do sistema de transportes estão associadas ao uso mais intensivo e adequado das modalidades ferroviária e aquaviária, aproveitando de suas eficiências energéticas e produtividades no deslocamento de fluxos de maior densidade e distância de transporte (BRASIL, 2007b).

Assim, foi dada ênfase às ações e projetos de adequação e expansão dos sistemas ferroviário e aquaviário, este último compreendendo a navegação interior, de cabotagem e de longo curso, buscando sua melhor integração multimodal com o sistema rodoviário.

Segundo o PNLT, com a concretização dos projetos e ações de adequação e expansão dos sistemas ferroviário e aquaviário, seria possível alterar, até 2023, a participação do modo ferroviário na matriz de transportes de $25 \%$ para $32 \%$ e do aquaviário de $13 \%$ para $29 \%$. O modo rodoviário, então com $58 \%$, participaria, com $33 \%$ na matriz brasileira de transporte de cargas, integrando-se ao sistema multimodal de transportes (Figura 5.2). Esperava-se, assim, um crescimento da eficiência e produtividade do transporte no Brasil, melhorando o seu desempenho operacional e a sua rentabilidade. 


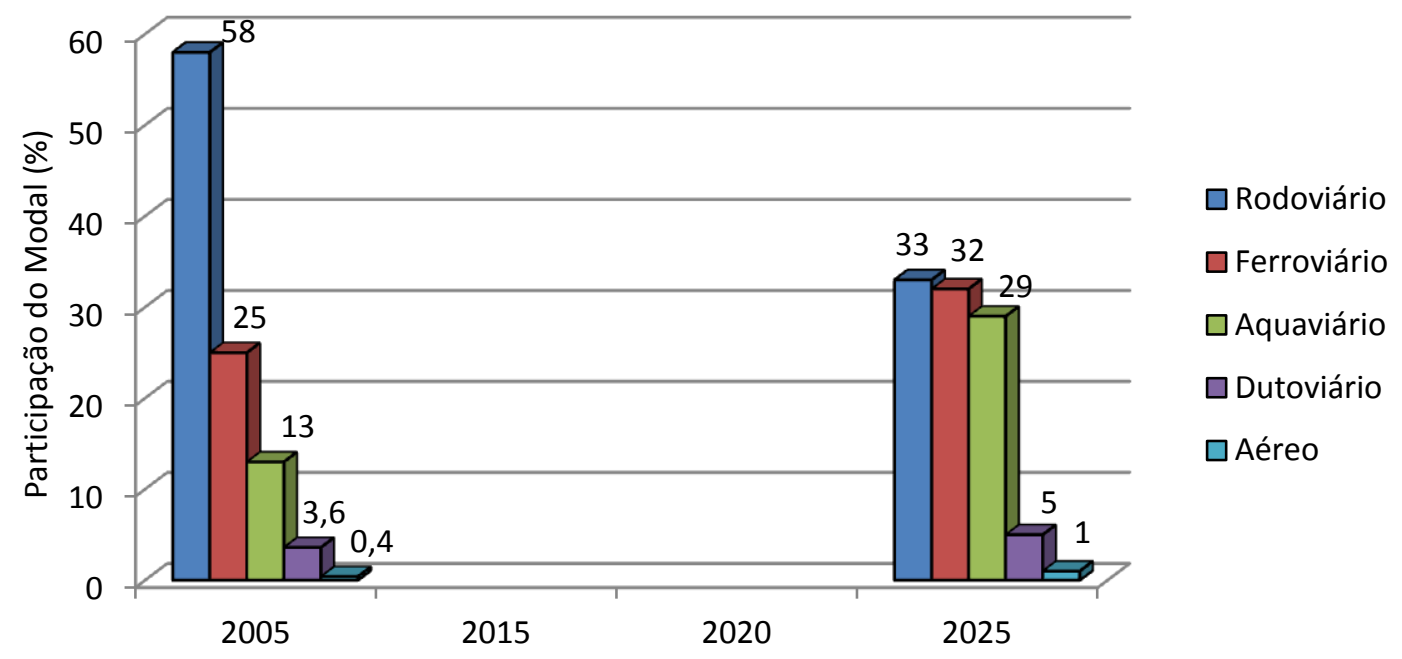

Figura 5.2 - Matriz de transportes brasileira no ano de 2005 e projeção para 2025. Fonte: BRASIL (2007b)

Em 2011, foi realizada a revisão do PNLT, com projeção de transporte até 2031. De acordo com o documento, na distribuição modal esperada para essa data, o transporte rodoviário corresponderia a $38 \%$, o ferroviário $43 \%$, o dutoviário $4 \%$ e o aquaviário $15 \%$ da matriz de transportes brasileira, sendo $6 \%$ transporte hidroviário interior e $9 \%$ cabotagem, conforme dados apresentados no gráfico da Figura 5.3. Observa-se que nesse cenário não há crescimento da participação do transporte hidroviário interior apesar do elevado potencial para esse transporte no País.

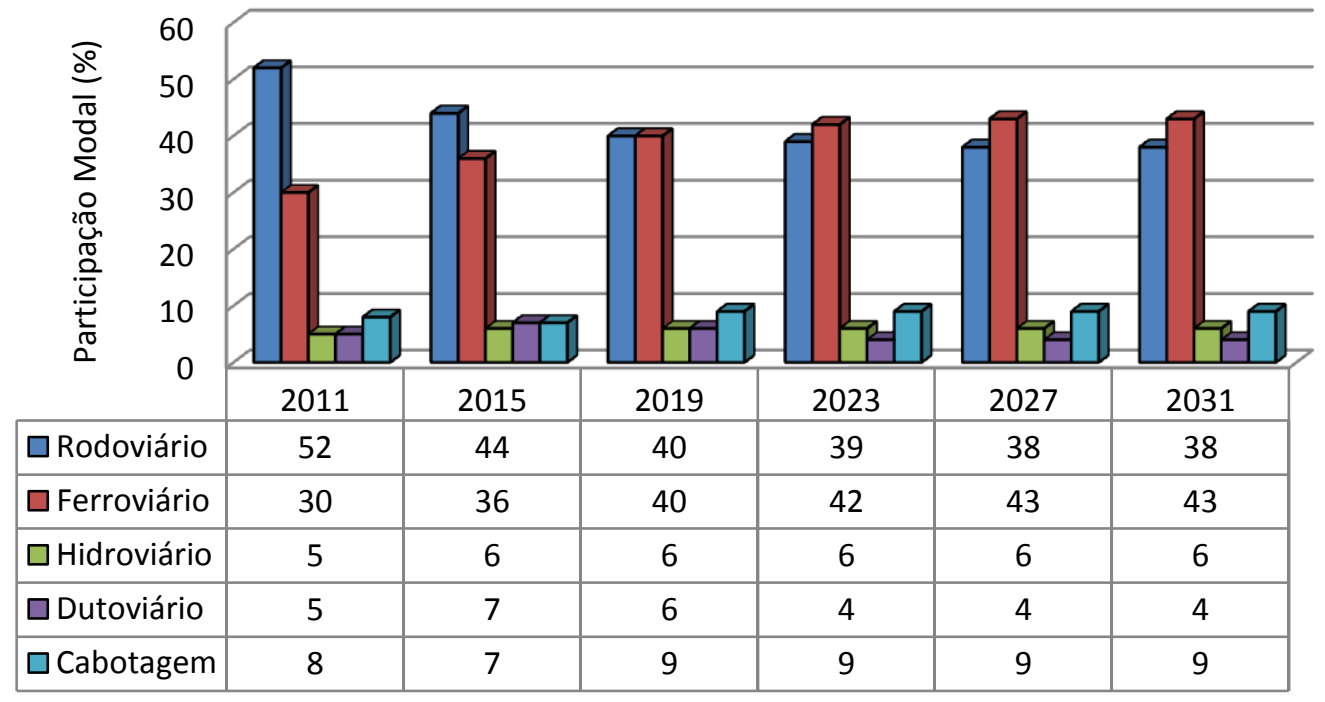

Figura 5.3 - Distribuição modal esperada no Brasil, entre 2011 e 2031. Fonte: BRASIL (2012) 


\subsection{Potencial para o THI no Brasil}

O Brasil tem, em média, aproximadamente $258.000 \mathrm{~m}^{3} / \mathrm{s}$ de água escoando por seus rios, o que representa aproximadamente $18 \%$ do potencial de superfície do planeta. Esse valor corresponde ao dobro das águas superficiais dos Estados Unidos e cerca de $80 \%$ a mais que países com dimensões continentais como o Canadá e a China, isso sem mencionar as variações climáticas que congelam as águas dos continentes do Hemisfério Norte e impedem a navegação dos rios daqueles países em praticamente metade do ano (SILVA, 2004).

De acordo com o documento "Diretrizes da Política Nacional de Transporte Hidroviário", do Ministério dos Transportes, o Brasil conta com 63 mil quilômetros de rios, lagos e lagoas, dos quais mais de 40 mil quilômetros são potencialmente navegáveis. No entanto, a navegação comercial ocorre em pouco mais de 13 mil quilômetros, com significativa concentração na Amazônia, onde os rios não carecem de maiores investimentos e as populações não dispõem de muitas opções de modos de transporte terrestres (BRASIL, 2010a).

A despeito desse elevado potencial para o transporte hidroviário, o Brasil insere-se no grupo de países com pequeno índice de aproveitamento de suas vias potencialmente navegáveis. Conforme já demonstrado anteriormente, o País optou pela utilização do modo rodoviário em detrimento dos demais modos de transporte.

Bastos (2006) afirma que esse fato é lastimável quando observada a grande extensão navegável de nossas bacias e quando existe certeza de que as hidrovias deveriam exercer papel significativo nos grandes eixos de transporte, em uma perspectiva de integração modal com as rodovias e ferrovias.

Azambuja (2005) argumenta que, em um país em desenvolvimento, como o Brasil, não se admite deixarem de serem utilizados os modos de transporte que apresentem menores custos e impactos ambientais, como é o caso do aquaviário. Entende o autor que, uma vez decidido pela sociedade que o transporte hidroviário é importante para o País, deveriam ser tomadas 
medidas eficazes para que sua utilização fosse otimizada, não se descartando a adoção de algum subsídio.

Países que contam com grande extensão tendem a priorizar os modos ferroviários e hidroviários, ao contrário do Brasil, onde a participação do transporte hidroviário na matriz de cargas ainda é muito pequena, devido, entre outros motivos, ao fato dos Governos terem priorizados investimentos na construção de rodovias (CHAMORRO, 2009).

Essa deficiência dos sistemas de transporte extrapola os limites do território brasileiro. A ONG WWF-Brasil, no documento "Retrato da Navegação no Alto Rio Paraguai", destaca que a falta de uma infraestrutura de transportes é um importante obstáculo ao crescimento do intercâmbio comercial entre os países da América Latina e, consequentemente, ao crescimento econômico da região. O relatório ressalta ainda que embora o sistema fluvial venha sendo utilizado como via navegável desde a época pré-colombiana, e que portos e outras instalações tenham sido construídos desde então, a manutenção dos mesmos deixaria muito a desejar (WWF, 2001).

Outros países produtores de grãos, que se destacam no comércio exterior, já possuem a mentalidade hidroviária, a tal ponto que sua aceitação deixou de ser uma questão técnica para ser política. A navegação interior oferece a capacidade de transportar grande quantidade de carga de uma só vez e combinada aos outros modos é a melhor solução econômica quando se trata de longas distâncias (SILVA, 2004).

Nenhum outro modo de transporte apresenta, em geral, custos de investimento, manutenção e operação tão baixos quanto o hidroviário. A produção brasileira compete diretamente com os fretes americanos substancialmente mais reduzidos, uma vez que, naquele país, os grãos são transportados pelo rio Mississipi e a hidrovia é considerada fator de segurança nacional (BRASIL, 2006a).

O Tribunal de Contas da União - TCU afirma que os principais motivos para a diferença entre as relações dos fretes hidroviário, rodoviário e ferroviário no Brasil e nos EUA são: a deficiência nas condições de navegação nas principais hidrovias brasileiras, reduzindo a rotatividade das embarcações; a baixa capacidade dos comboios em função de deficiências nas vias e a não utilização de equipamentos modernos de propulsão e manobra (BRASIL, 
2006c). Segundo o documento, outro fator que leva à majoração do frete nas hidrovias brasileiras é a falta de concorrência em alguns mercados, permitindo que o frete hidroviário seja calculado com base no rodoviário.

Por outro lado, há uma demanda reprimida de transporte hidroviário no País e caso haja garantia de que as hidrovias sejam bem sinalizadas e os canais de navegação sejam mantidos em níveis economicamente viáveis para a navegação comercial, haverá aumento do interesse pelo seu uso, com repercussões positivas para a redução do custo de logística no Brasil (BRASIL, 2006b).

Apesar da potencialidade e vantagens que esse modo de transporte oferece, sua utilização não deve ser considerada de forma isolada. Com poucas exceções, o transporte hidroviário é dependente de integrações intermodais eficientes para sua plena utilização.

Normalmente, a modalidade hidroviária não é competitiva por si só no que tange à captação ou entrega de cargas em determinada região. Ela depende de pontos de interconexão com as demais modalidades de transporte, seja por meio de portos ou de terminais interiores. Portanto, não há de se considerar transporte hidroviário interior sem que se estabeleça uma estrutura de transportes intermodal.

Assim, o transporte hidroviário deve ser parte de uma conjuntura de transporte intermodal, no qual trabalhe em conjunto com os modos ferroviário e rodoviário, e isso envolve a responsabilidade de cada um em garantir que a carga transportada cruze essas fronteiras modais de forma segura, efetiva e dentro de um tempo previamente estipulado.

Segundo a Fundação João Pinheiro (1979), dado o papel que ocupam as hidrovias no contexto mais amplo do sistema de transportes, a complementaridade intermodal deve ser um dos aspectos privilegiados no que se refere ao modo hidroviário.

Também nessa linha, Almeida (2004) faz a seguinte explanação sobre o sistema de transporte e a intermodalidade:

O investimento na formação de infraestrutura pública de transporte está relacionado às características particulares da infraestrutura e do sistema de transporte onde ela se insere. Segundo Caixeta-Filho \& Martins (2001), os investimentos em infraestrutura de transporte devem ser definidos segundo o critério da produtividade, selecionando-se os projetos mais produtivos. Esses autores afirmam 
que a busca pela competitividade nos mercados externos reforça a discussão sobre a estrutura de divisão modal de cargas e de passageiros. Essa realidade exige modais de transporte operacionalmente eficientes e de menores custos de deslocamento de mercadorias entre origens e destinos, premiando a intermodalidade. Sobre esse aspecto, a Administração das Hidrovias do Tocantins e Araguaia (AHITAR) (1999) afirma que nenhum modal de transporte é melhor do que outro. Rodovia, ferrovia e hidrovia não concorrem entre si. Na realidade, a opção por investimento em um determinado modal depende das injunções de logística que articulam a multimodalidade, no sentido de obter eficiência, eficácia e redução de custo no deslocamento de cargas. Em longas distâncias é a combinação de pelo menos dois modais que permite uma adequação econômica que leva à sustentabilidade. Nesse contexto, Laksmanan et al. (2001) realçam que o investimento na consolidação de um efetivo sistema intermodal de transportes reduziria obstáculos físicos dos corredores custo-efetivos potenciais, tais como: ausência de travessias; pontes estreitas e frágeis; iluminação precária; trechos rodoviários sem manutenção; rede ferroviária com diferentes bitolas; sinalização hidroviária inadequada; e, condições precárias para transbordo e armazenamento de carga. (ALMEIDA, 2004)

Filippo (1999) reforça essa ideia enquanto afirma que a eficiência e a integração entre os diversos modos de transportes são fatores fundamentais para o crescimento econômico de uma nação, pois permitem o incremento da produção do transporte de passageiros e de cargas, tornando o País inclusive, mais competitivo no mercado mundial.

\subsection{Características do Transporte Hidroviário}

É possível fazer diversas comparações entre os modos de transportes. De forma geral, o modo hidroviário apresenta vantagens comparativas em relação aos demais, principalmente o rodoviário, especialmente para 0 transporte de cargas de baixo valor agregado em médias e longas distâncias. Diversas são as vantagens, econômicas, sociais e ambientais, que podem ser oferecidas pelo transporte hidroviário interior, dentre as quais, podem ser citadas:

- Redução no custo do transporte de carga, especialmente das cargas pesadas, volumosas e de baixo valor unitário, transportadas a grandes distâncias;

- Com poucas intervenções e investimentos, dezenas de milhares de quilômetros de malha viária ficariam disponíveis para a navegação;

- Mobiliza maior carregamento de uma só vez, pois a capacidade de carga de uma embarcação ou comboio é maior; 
- Apresenta menores custos de implantação e manutenção da via;

- Apresenta menor consumo de combustível e maior eficiência energética;

- Devido ao fato de ser mais eficiente, o transporte fluvial acarreta benefícios ambientais significativos, pois reduz a utilização de combustíveis e consequentemente a diminuição da emissão de gases e outros poluentes;

- Menor dispêndio com mão de obra, pelas reduzidas tripulações utilizadas;

- É mais seguro, apresenta menores índices de acidentes, reduzido congestionamento e causa menor nível de ruído;

- Diminui a exaustão de recursos naturais, pois apresenta menor consumo de combustível e menor peso necessário para transportar uma unidade de carga além do maior tempo de vida útil dos veículos;

- Auxilia e facilita a intermodalidade dos transportes.

É possível encontrar na literatura diversas informações comparativas entre os modos rodoviário, ferroviário e aquaviário. O Quadro 5.2 apresenta uma compilação dos principais parâmetros para os três modos de transporte, na qual é possível observar por meio de dados quantitativos algumas vantagens do modo aquaviário. 
Quadro 5.2 - Parâmetros de transporte para os modos rodoviário, ferroviário e aquaviário.

\begin{tabular}{|c|c|c|c|c|}
\hline \multicolumn{2}{|c|}{ Parâmetros } & Rodoviário & Ferroviário & Aquaviário \\
\hline \multicolumn{2}{|c|}{ Custo Médio de Construção USS/Km ${ }^{(1)(2)(3)(4)}$} & 440.000 & 1.400 .000 & 34.000 \\
\hline \multicolumn{2}{|c|}{ Custo de Manutenção ${ }^{(1)(4)}$} & alto & alto & baixo \\
\hline \multicolumn{2}{|c|}{ Custo de manutenção da via ${ }^{(2)(3)}$} & alto & baixo & baixo \\
\hline \multicolumn{2}{|c|}{$\underset{(1)(2)(3)(4)}{\text { Consumo de combustível Litros/ton/1000km }}$} & 96 & 10 & 5 \\
\hline \multicolumn{2}{|c|}{ Custo de frete USS/ton/1000km ${ }^{(1)(4)}$} & 34 & 21 & 12 \\
\hline \multicolumn{2}{|c|}{$\begin{array}{l}\text { Custos de fretes, para cada ton transportada } \\
(\mathrm{R} \$ / \mathrm{Km})^{(5)}\end{array}$} & 0,016 & 0,056 & 0,009 \\
\hline \multicolumn{2}{|c|}{ Custo Médio de Operação USS/Km ${ }^{(2)(3)}$} & 34 & 21 & 12 \\
\hline \multicolumn{2}{|c|}{ Custos Sociais $\left(^{*}\right)\left(\mathrm{USS} / 100\right.$ ton/km) ${ }^{(2)(3)}$} & 3,2 & 0,74 & 0,23 \\
\hline \multirow{3}{*}{$\begin{array}{l}\text { Emissão de } \\
\text { Poluentes } \\
\text { (kg/ton/1000km) }\end{array}$} & Hidróxido de carbono & 0,178 & 0,129 & 0,025 \\
\hline & Monóxido de carbono & 0,536 & 0,180 & 0,056 \\
\hline & Oxido de carbono & 2,866 & 0,516 & 0,149 \\
\hline \multicolumn{2}{|c|}{ Vida útil da infraestrutura ${ }^{(2)(3)}$} & Baixa & Alta & Alta \\
\hline \multicolumn{2}{|l|}{ Vida útil (anos) ${ }^{(8)}$} & 10 & 30 & 50 \\
\hline \multicolumn{2}{|c|}{ Distância de transporte com US\$1 em $1979(\mathrm{~km})^{(3)}$} & 24 & 107 & 537 \\
\hline \multicolumn{2}{|c|}{ Massa transportada por $1 \mathrm{HP}$ de potência $(\mathrm{kg})^{(3)(8)}$} & 150 & 500 & 4000 \\
\hline \multicolumn{2}{|c|}{ Peso morto por tonelada de carga $(\mathrm{kg})^{(8)}$} & 700 & 800 & 350 \\
\hline \multicolumn{2}{|c|}{$\begin{array}{l}\text { Distância percorrida com 1 galão de combustível } \\
\text { para transportar } 1 \text { ton de carga }(\mathrm{km})^{(7)}\end{array}$} & 109 & 374 & 952 \\
\hline
\end{tabular}

Fonte: Compilação realizada pelo autor. (1) Secretaria de Estado dos Transportes (2002) apud SINAY, TEIXEIRA e AMORIM (2005); (2) AHSFRA (2007) apud DINIZ, SINAY e FERRO (2007); (3) SCHAPPO et al. (2008); (4) Secretaria de Transporte de São Paulo (2007) apud Diniz (2007); (5) Superintendência de Portos e Hidrovias (2007) apud Garaventta (2008); (6) www.centrodelogistica.org apud Chamorro (2009); (7) Eastman (1980); (8) Nazaré (1993); (9) Beuthe et al. (2002); ( ${ }^{*}$ Inclui acidentes, poluição atmosférica e sonora, consumo de espaço e água.

Nazaré (1993) faz a comparação dos equipamentos necessários para transportar 1.000 toneladas pelos três modos. De acordo com esse autor, para transportar essa quantidade de carga no modo rodoviário seriam necessários 50 cavalos mecânicos e 50 reboques, no ferroviário uma locomotiva e 50 vagões e, no aquaviário, apenas um empurrador e uma balsa.

Com essas informações, já é possível inferir que o frete hidroviário deve ser menor que o dos demais. Tal assertiva pode ser confirmada no Quadro 5.3, que apresenta uma compilação de valores de fretes, apresentados em diversos documentos, realizada por Rossetto Jr. (2005). 
Quadro 5.3 - Comparação de Fretes por modo de transporte (US\$ / t . 1000 km).

\begin{tabular}{|l|c|c|c|}
\hline \multicolumn{1}{|c|}{ Fontes } & Rodoviário & Ferroviário & Hidroviário \\
\hline $\begin{array}{l}\text { Relatório Hidrovia Tietê-Paraná } \\
\text { IPT - 1994 }\end{array}$ & 40 & 28 & 12 \\
\hline $\begin{array}{l}\text { Relatório a Onda do Progresso } \\
\text { R. Pavan - 1995 }\end{array}$ & 35 & 20 & 14 \\
\hline $\begin{array}{l}\text { JICA - Japa International } \\
\text { Cooperation Agency - 1995 }\end{array}$ & 61 & 20 & 18 \\
\hline $\begin{array}{l}\text { Relatório Rios de Negócios } \\
\text { CESP - 1997 }\end{array}$ & 35 & 17 & 13 \\
\hline $\begin{array}{l}\text { Consultoria } \\
\text { J. C. T. Riva - 2004 }\end{array}$ & 32 & 20 & 12 \\
\hline $\begin{array}{l}\text { SIFRECA } \\
\text { ESALQ - 2005 }\end{array}$ & 30 & 22 & 13 \\
\hline Média & 39 & 21 & 14 \\
\hline
\end{tabular}

Fonte: ROSSETTO JR. (2005)

Além dos custos, os critérios para a escolha dos modos de transporte levam em consideração as características operacionais de cada serviço. Chamorro (2009) apresenta cinco dimensões, que considera mais importantes, referentes às características operacionais dos serviços oferecidos por cada um dos modos de transporte, sendo elas: velocidade, confiabilidade, capacidade, disponibilidade e frequência. No Quadro 5.4, pode-se observar como essas características se apresentam em cada modo, seguindo uma pontuação crescente de 1 a 5 .

Quadro 5.4 - As cinco dimensões (velocidade, confiabilidade, capacitação, disponibilidade e frequência) referentes às características operacionais dos serviços oferecidos por cada um dos modos de transporte.

\begin{tabular}{|c|c|c|c|c|c|}
\hline & Rodoviário & Ferroviário & Aquaviário & Aéreo & Dutoviário \\
\hline Velocidade & 2 & 3 & 4 & 1 & 5 \\
\hline Disponibilidade & 1 & 2 & 4 & 3 & 5 \\
\hline Confiabilidade & 2 & 3 & 4 & 5 & 1 \\
\hline Capacidade & 3 & 2 & 1 & 4 & 5 \\
\hline Frequência & 2 & 4 & 5 & 3 & 1 \\
\hline Resultado & 10 & 14 & 18 & 16 & 17 \\
\hline
\end{tabular}

Fonte: www.centrodelogistica.org apud Chamorro (2009)

Além das vantagens já elencadas, o modo hidroviário, comparativamente aos demais modos de transporte, é, segundo estudos realizados, o que acarreta menos impactos negativos ao meio ambiente. Várias 
razões justificam essa afirmação, entre eles, a eficiência e o fato de a via ser constituída por rios, lagoas, lagos, baías e enseadas, o que faz com que ela se integre naturalmente com o meio ambiente, mesmo sofrendo intervenções para permitir o transporte de grandes volumes de carga de maneira segura e econômica (FILIPPO, 1999).

Beuthe et al. (2002) apresentam um estudo dos custos externos (ou sociais), abordando os parâmetros: congestionamentos, poluição, acidentes, ruído e desgastes. O Quadro 5.5 mostra o resultado de uma simulação feita para o transporte de cargas, por três modos, de longo curso na Bélgica em um ano.

Quadro 5.5 - Custos externos (ou sociais) levantados por simulação para o transporte de cargas de longo curso na Bélgica em um ano, para caminhões, trens e barcos.

\begin{tabular}{|l|c|c|c|}
\hline $\begin{array}{c}\text { Custos externos } \\
\text { (milhões de euros) }\end{array}$ & Caminhão & Trem & Barco \\
\hline Congestionamentos & 412,8 & & 88,2 \\
\hline Poluição & 419,7 & 51,9 & - \\
\hline Acidentes & 298,6 & 25,1 & - \\
\hline Ruído & 153,3 & 32 & - \\
\hline Desgastes das vias & 46,4 & - & 88,2 \\
\hline Total & $1.330,8$ & 109 & \\
\hline
\end{tabular}

Fonte: Beuthe et al. (2002)

Santana (2008) cita estudo realizado em 12 países da Comunidade Europeia sobre impactos dos transportes sobre o meio ambiente comparando diferentes modos, que mostrou que o transporte fluvial teve menores índices de impactos ambientais, conforme pode ser visto no Quadro 5.6.

Quadro 5.6 - Custos sociais em relação às modalidades de transporte (\%).

\begin{tabular}{|l|c|c|c|c|}
\hline \multicolumn{1}{|c|}{ Custos Sociais } & Rodoviário & Ferroviário & Fluvial & Aéreo \\
\hline Poluição Atmosférica & 91 & 4 & 3 & 2 \\
\hline Poluição Sonora & 64 & 10 & 0 & 26 \\
\hline Uso da terra & 91 & 7 & 1 & 1 \\
\hline Construção/Manutenção & 56 & 37 & 5 & 2 \\
\hline Acidentes & 98 & 1 & 0 & 1 \\
\hline
\end{tabular}

Fonte: Frauenhofer Institute Karlsruhe (1994) apud Santana (2008) 
Observa-se, portanto, que o transporte hidroviário pode contribuir para o desenvolvimento social e econômico, oferecendo benefícios nacionais e regionais como a redução no preço final do produto transportado, em função de eventual redução do frete, o que poderia estimular a produção agrícola, a geração de empregos para a população, não só em face das obras e serviços necessários à operação da hidrovia, mas também em função das atividades econômicas que venham a se desenvolver no seu entorno e o impulso ao turismo na região cortada pela via (CARVALHO, 2008). 


\section{REDE HIDROVIÁRIA BRASILEIRA}

\subsection{Plano Nacional de Viação}

A Lei ํㅜ 5.917, de 10 de setembro de 1973, apresenta relação descritiva das vias navegáveis interiores e das interligações de bacias do Plano Nacional de Viação. Na referida lei, a extensão hidroviária no Brasil foi avaliada em 39.904 quilômetros, considerando o total das vias navegáveis que estão relacionadas no Quadro 6.1. Foram propostas ainda nove interligações, previstas para efeito de continuidade da navegação, que são apresentadas no Quadro 6.2.

Quadro 6.1 - Relação Descritiva das Hidrovias do Plano Nacional de Viação.

\begin{tabular}{|c|c|c|}
\hline Rio & Pontos extremos & $\begin{array}{l}\text { Extensão Aproximada } \\
\qquad(\mathrm{km})\end{array}$ \\
\hline \multicolumn{3}{|c|}{ BACIA AMAZÔNICA } \\
\hline Amazonas & Foz/Benjamin Constant & 3.108 \\
\hline Negro & Manaus/Cucuí & 1.210 \\
\hline Branco & Foz/Confluência Urariguera/Tacutu & 577 \\
\hline Juruá & Foz/Cruzeiro do Sul & 3.489 \\
\hline Tarauacá & Foz/Tarauacá & 660 \\
\hline Embira & Foz/Feijó & 194 \\
\hline Javari & Foz/Boca do Javari-Mirim & 510 \\
\hline Japurá & Foz/Vila Bittencourt & 721 \\
\hline Içá & Foz/lpiranga & 368 \\
\hline Purus & Foz/Sena Madureira(norio laco) & 2.846 \\
\hline Acre & Foz/Brasiléia & 796 \\
\hline Madeira & Foz/Confluência Mamoré/Beni & 1.546 \\
\hline Guaporé & Foz/Cidade de Mato Grosso & 1.180 \\
\hline Tapajós & Santarém/Itaituba & 359 \\
\hline Xingu & Porto Moz/Altamira (Belo Monte) & 298 \\
\hline Tocantins & Belém/Peixe & 1.731 \\
\hline Araguaia & Foz/Balisa & 1.800 \\
\hline \multirow[t]{2}{*}{ Mamoré } & Foz/Confluência com Guaporé & 225 \\
\hline & TOTAL & 21.618 \\
\hline \multicolumn{3}{|c|}{ BACIA DO NORDESTE } \\
\hline Mearim & Foz/Barra do Corda & 470 \\
\hline Grajaú & Foz/Grajaú & 500 \\
\hline Pindaré & Foz/Pindaré-Mirim & 110 \\
\hline Itapicuru & Foz/Colinas & 565 \\
\hline
\end{tabular}




\begin{tabular}{|c|c|c|}
\hline Rio & Pontos extremos & $\begin{array}{l}\text { Extensão Aproximada } \\
\qquad(\mathrm{km})\end{array}$ \\
\hline Parnaíba & Foz/Santa Filomena & 1.176 \\
\hline \multirow[t]{2}{*}{ Balsas } & Foz/Balsas & 225 \\
\hline & TOTAL & 3.046 \\
\hline \multicolumn{3}{|c|}{ BACIA DO SÃO FRANCISCO } \\
\hline \multirow[t]{2}{*}{ São Francisco } & Foz/Piranhas & 208 \\
\hline & Cachoeira Itaparica/Pto Real (Iguatama) & 2.207 \\
\hline Paracatu & Foz/Buriti & 284 \\
\hline Velhas & Foz/Sabará & 659 \\
\hline Paraopeba & Foz/Florestal & 240 \\
\hline Grande & Foz/Barreiras & 358 \\
\hline Preto & Foz/lbipetuba & 125 \\
\hline \multirow[t]{2}{*}{ Corrente } & Foz/Santa Maria da Vitória & 95 \\
\hline & TOTAL & 4.176 \\
\hline \multicolumn{3}{|c|}{ BACIA DO LESTE } \\
\hline Doce & Foz/lpatinga & 410 \\
\hline \multirow[t]{2}{*}{ Paraíba do Sul } & Foz/Jacareí & 670 \\
\hline & TOTAL & 1.080 \\
\hline \multicolumn{3}{|c|}{ BACIA DO SUDESTE } \\
\hline Ribeira do Iguape & Foz/Registro & 70 \\
\hline Jacuí & Foz/Dona Francisca & 370 \\
\hline Taquari & Foz/Mussum & 205 \\
\hline Caí & Foz/São Sebastião do Caí & 93 \\
\hline Sinos & Foz/Paciência & 47 \\
\hline Gravataí & Foz/Gravataí & 12 \\
\hline Jaguarão & Foz/Jaguarão & 32 \\
\hline Camaquã & Foz/São José do Patrocínio & 120 \\
\hline Lagoa Mirim & Pelotas/Santa Vitória do Palmar & 180 \\
\hline \multirow[t]{2}{*}{ Lagoa dos Patos } & Porto Alegre/Rio Grande & 230 \\
\hline & TOTAL & 1.359 \\
\hline \multicolumn{3}{|c|}{ BACIA DO PARAGUAI } \\
\hline Paraguai & Foz do Apa/Cáceres & 1.323 \\
\hline Cuiabá-São Lourenço & Foz/Rosário do Oeste & 785 \\
\hline Taquari & Foz/Coxim & 430 \\
\hline \multirow[t]{2}{*}{ Miranda } & Foz/Miranda & 255 \\
\hline & TOTAL & 2.793 \\
\hline \multicolumn{3}{|c|}{ BACIA DO PARANÁ } \\
\hline Piracicaba* & Foz/Paulínea* & \\
\hline Paraná & Foz/lguaçu/Confluência/Paraíba/Grande & 808 \\
\hline Paranapanema & Foz/Salto Grande & 421 \\
\hline Tietê & Foz/Mogi das Cruzes & 1.010 \\
\hline Pardo & Foz/Ponto da Barra & 170 \\
\hline Ivinheima & Foz/Confluência Brilhante & 270 \\
\hline Brilhante & Foz/Pto. Brilhante & 67 \\
\hline
\end{tabular}




\begin{tabular}{|l|l|c|}
\hline \multicolumn{1}{|c|}{ Rio } & \multicolumn{1}{|c|}{ Pontos extremos } & $\begin{array}{c}\text { Extensão Aproximada } \\
(\mathrm{km})\end{array}$ \\
\hline Inhanduí & Foz/Pto. Tupi & 79 \\
\hline Paranaíba & Foz/Escada Grande & 787 \\
\hline Iguaçu & Foz/Curitiba & 1.020 \\
\hline & TOTAL & 4.632 \\
\hline & \multicolumn{1}{|c|}{ BACIA DO URUGUAI } \\
\hline Uruguai & Barra do Quaraí/lraí & 840 \\
\hline Ibicuí & Foz/Confluência do Santa Maria & 360 \\
\hline & TOTAL & 1.200 \\
\hline & TOTAL GERAL & 39.904 \\
\hline
\end{tabular}

* - Trecho incluído pela Lei ํㅜ 6.630, de 1979.

Fonte: Lei no 5.917 , de 1973

Quadro 6.2 - Interligação de Bacias do Plano Nacional de Viação.

\begin{tabular}{|c|c|}
\hline Interligação & Trecho a ser tornado navegável \\
\hline Paraguai-Guaporé & Foz do Jaurú-Cidade de Mato Grosso \\
\hline Paraná-Paraguai & Rio Paraná-Coxim \\
\hline Paranaíba-São Francisco & Escada grande-Buriti (Rio Paracatu) \\
\hline Tietê-Paraíba do Sul & Mogi das Cruzes-Jacareí \\
\hline Taquari-Araguaia & Coxim-Balisa \\
\hline Ibicuí-Jacuí & Vacacaí-Ibicuí \\
\hline Canal do Varadouro & Baía de Paranaguá-Baía de Cananéia \\
\hline Canal Santa Maria & Rio Sergipe-Rio Vaza Barris \\
\hline Canal Tartaruga-Jenipapocu e Arari & Na Ilha de Marajó \\
\hline
\end{tabular}

Fonte: Lei no 5.917/73.

De acordo com a Lei ํㅗ 5.917/73, o Sistema Hidroviário Nacional é constituído pelas vias navegáveis (rios, lagos e canais), incluindo suas instalações e acessórios complementares, e pelo conjunto das atividades e meios estatais diretos de operação da navegação hidroviária, que possibilitam o uso adequado das citadas vias para fins de transporte. As vias navegáveis consideradas no Plano Nacional de Viação se referem às principais, quanto à extensão ou ao tráfego.

Posteriormente, foram sendo acrescidas novas medições, conforme previa a referida lei, segundo a qual deveria ser feita uma atualização a cada 
cinco anos. Porém, somente em 1979, por meio da Lei $\mathrm{n}^{\circ}$ 6.630, as informações foram atualizadas.

Em 2005, as extensões aproximadas da Rede Hidroviária Brasileira podiam ser demonstradas e detalhadas conforme exposto no Quadro 6.3, onde se verifica que o total da extensão da malha hidroviária brasileira seria maior do que 40.000 quilômetros.

Quadro 6.3 - Rede Hidroviária Brasileira em 2005.

\begin{tabular}{|c|c|c|c|c|}
\hline \multirow{2}{*}{ Bacia } & \multicolumn{2}{|c|}{ Extensão aproximada (km) } & \multirow{2}{*}{ Rios } \\
\cline { 2 - 4 } Amazônica & Navegáveis & Potenciais & Total & $\begin{array}{c}\text { Amazonas, Solimões, } \\
\text { Negro, Branco, } \\
\text { Madeira, Purus, } \\
\text { Juruá, Tapajós, Teles } \\
\text { Pires, Guaporé. }\end{array}$ \\
\hline Nordeste & 18.300 & 723,5 & $19.023,5$ & $\begin{array}{c}\text { Mearim, Pindaré, } \\
\text { Itapecuru, Parnaíba, } \\
\text { Balsas. }\end{array}$ \\
\hline Tocantins/Araguaia & 2.200 & 1.300 & 3.500 & $\begin{array}{c}\text { Tocantins, Araguaia, } \\
\text { das Mortes. }\end{array}$ \\
\hline São Francisco & 1.400 & 2.700 & 4.100 & $\begin{array}{c}\text { São Francisco, } \\
\text { Grande, Corrente. }\end{array}$ \\
\hline Leste & - & 1.094 & 1.094 & $\begin{array}{c}\text { Doce, Paraíba do Sul, } \\
\text { Jequetinhonha. }\end{array}$ \\
\hline Paraná & 1.900 & 2.900 & 4.800 & $\begin{array}{c}\text { Paraná, Tietê, } \\
\text { Paranaíba, Grande, } \\
\text { Ivaí, Ivinhema. }\end{array}$ \\
\hline Paraguai & 1.280 & 1.815 & 3.095 & $\begin{array}{c}\text { Paraguai, Cuiabá, } \\
\text { Miranda, São } \\
\text { Lourenço, } \\
\text { Taquariejauro. }\end{array}$ \\
\hline Sudeste & 600 & 700 & 1.300 & $\begin{array}{c}\text { Jacuí, Taquari, Lagoa } \\
\text { dos Patos, Lagoa } \\
\text { Mirim. }\end{array}$ \\
\hline Uruguai & - & 1.200 & 1.200 & Uruguai, Ibicuí. \\
\hline Total & 27.420 & $15.407,5$ & $42.827,5$ & \\
\hline
\end{tabular}

Fonte: Ministério dos Transportes (2005) apud SANTANA (2008)

Em janeiro de 2011, foi aprovada a Lei Ordinária nº 12.379, que dispõe sobre o Sistema Nacional de Viação e em seus anexos, que foram vetados, apresenta a relação descritiva das vias navegáveis existentes e planejadas integrantes do Subsistema Aquaviário Federal, segundo a bacia ou o rio em que se situam, totalizando 56.594 quilômetros.

De acordo com Santana (2008), pode haver desencontros de informações sobre a extensão hidroviária brasileira entre vários órgãos 
governamentais, que ocorrem por considerações diversas sobre períodos de navegação, sazonalidade das águas e estirões navegáveis.

\subsection{Divisão das Hidrovias}

O Conselho Nacional de Recursos Hídricos - CNRH instituiu por meio da Resolução no 32, de 25 de junho de 2003, a Divisão Hidrográfica Nacional, que divide 0 território em regiões hidrográficas. A região hidrográfica é 0 espaço territorial brasileiro compreendido por uma bacia, grupo de bacias ou sub-bacias hidrográficas contíguas com características naturais, sociais e econômicas homogêneas ou similares, com vistas a orientar o planejamento e o gerenciamento dos recursos hídricos. As regiões hidrográficas do Brasil podem ser visualizadas na Figura 6.1.

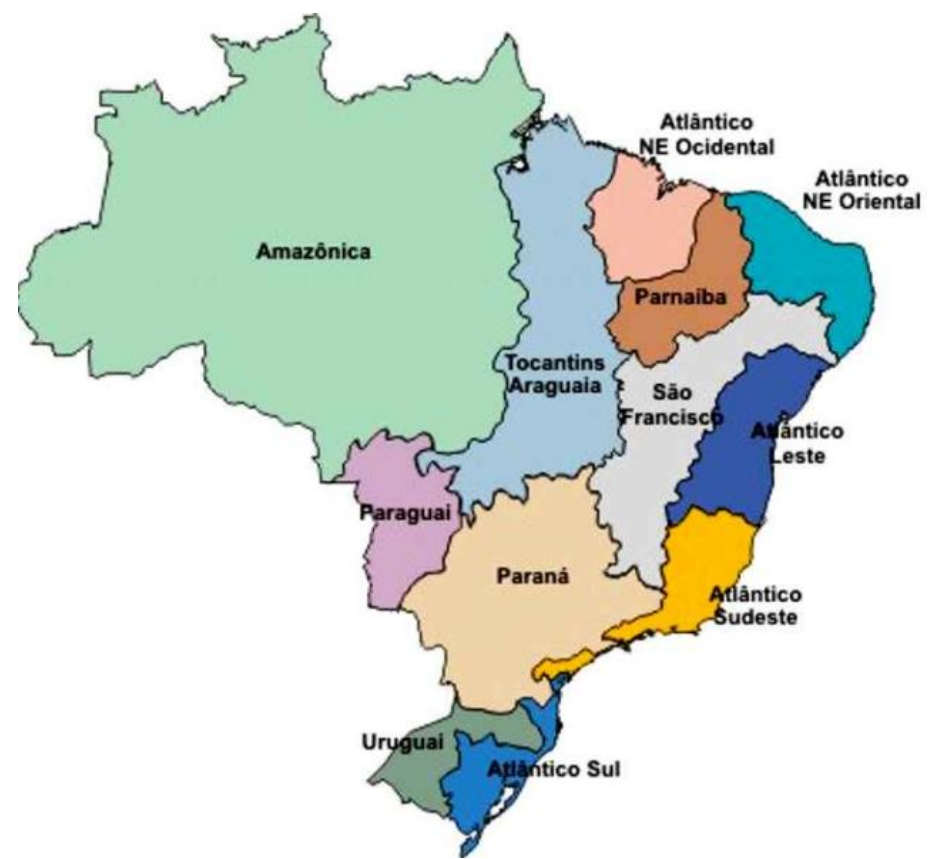

Figura 6.1 - Regiões Hidrográficas do Brasil de acordo com a Resolução CNRH nํㅜ 32, de 15 de outubro de 2003.

No entanto, Brasil (2012a) divide, de forma geral, o território brasileiro em vetores logísticos. Especificamente para o transporte hidroviário a divisão utilizada são as Bacias Hidroviárias. A Figura 6.2 apresenta os vetores logísticos e a Figura 6.3 a Rede Hidroviária Brasileira. 


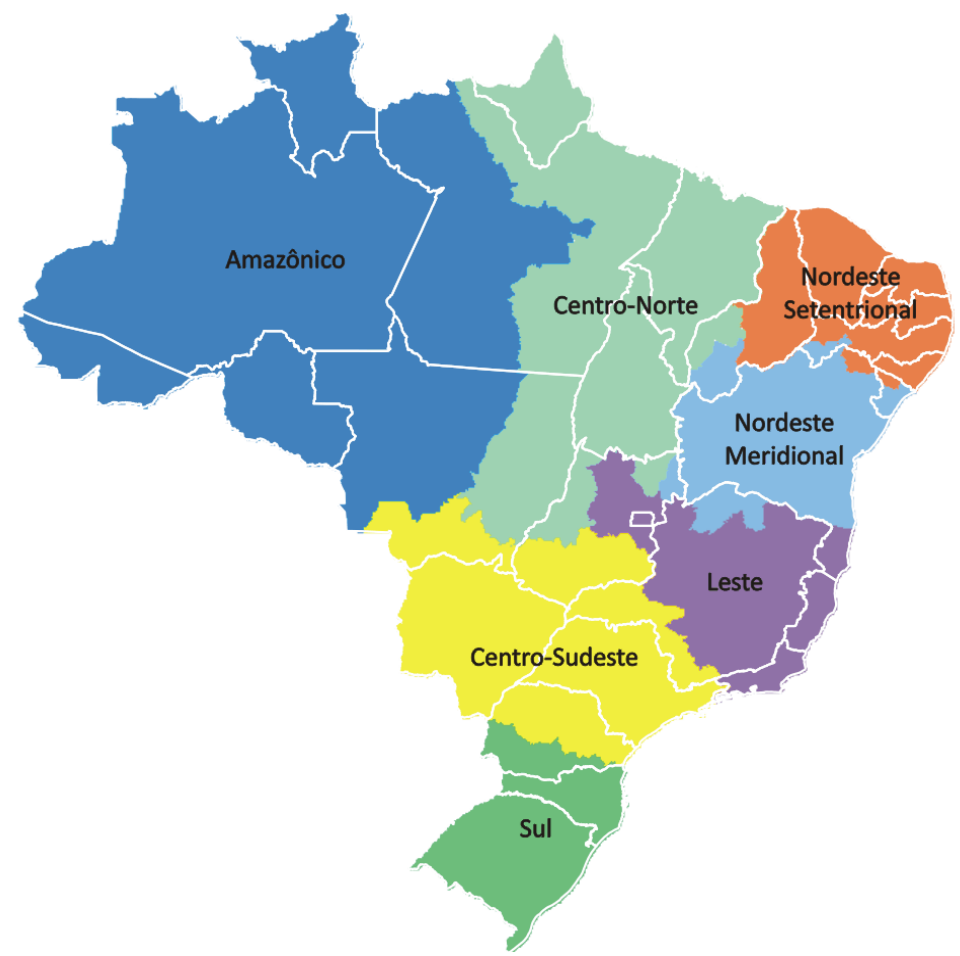

Figura 6.2 - Vetores Logísticos.

Fonte: BRASIL (2012a)

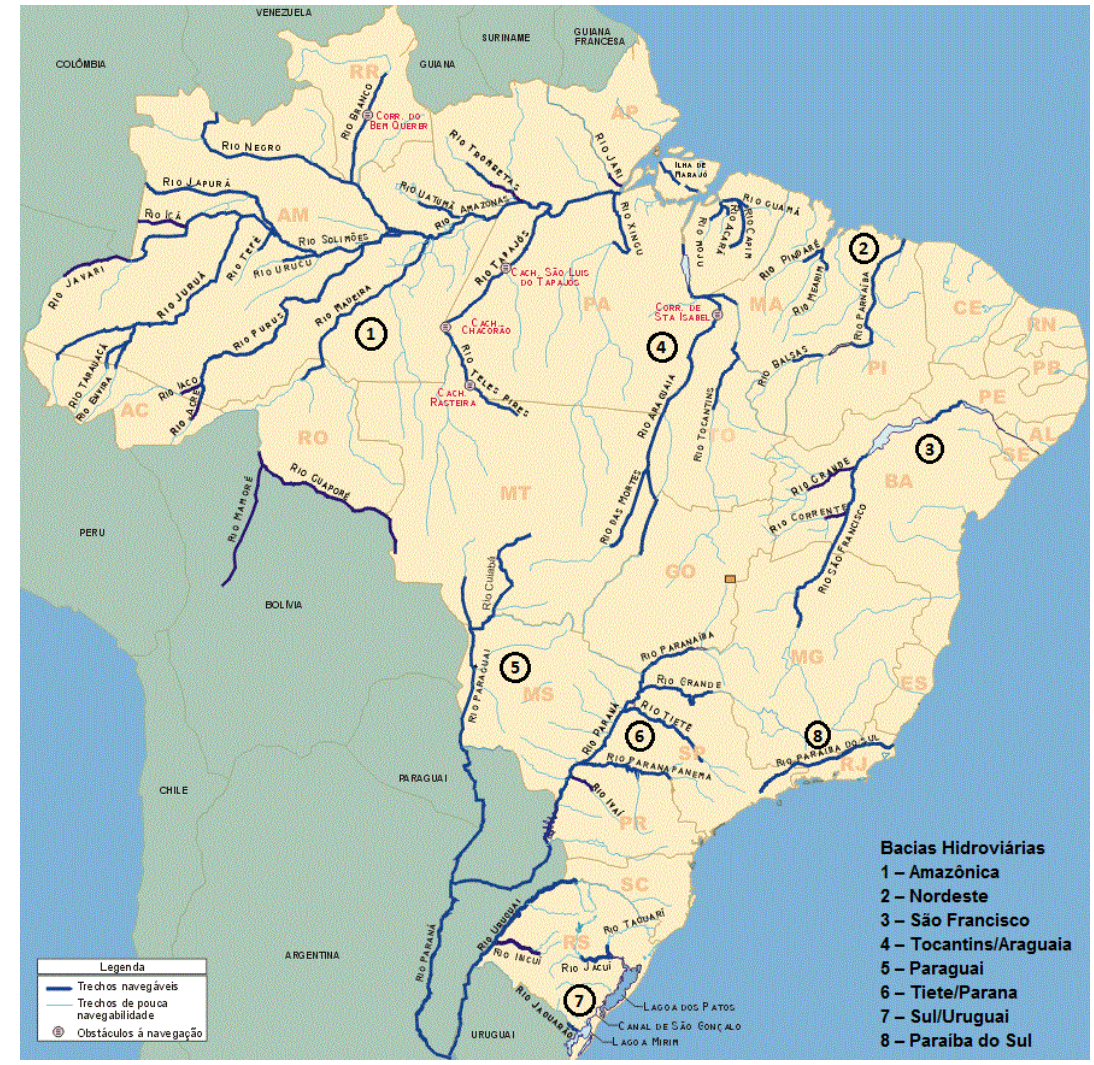

Figura 6.3 - Rede Hidroviária Brasileira.

Fonte: Guia Geográfico - Brasil Turismo (adaptado). Disponível em: http://www.brasilturismo.com/mapas/mapa/hidrovias-brasil.gif 
As atividades em cada uma dessas bacias hidroviárias são desempenhadas por Administrações Hidroviárias, dividas conforme o Quadro 6.4. Os dados das principais bacias hidroviárias são apresentados no Apêndice A.

Quadro 6.4 - Bacias Hidroviárias segundo o Ministério dos Transportes e respectivas Administrações Hidroviárias.

\begin{tabular}{|l|l|}
\hline \multicolumn{1}{|c|}{ Bacias Hidroviárias } & \multicolumn{1}{c|}{ Administrações Hidroviárias } \\
\hline Bacia Amazônica Ocidental & $\begin{array}{l}\text { Administração da hidrovia da Amazônia Ocidental - } \\
\text { AHIMOC }\end{array}$ \\
\hline Bacia Amazônica Oriental & Administração da hidrovia da Amazônia Oriental - AHIMOR \\
\hline Bacia do Tocantins e Araguaia & Administração da hidrovia do Tocantins/Araguaia - AHITAR \\
\hline Bacia do Nordeste & Administração da hidrovia do Nordeste - AHINOR \\
\hline Bacia do São Francisco & Administração da hidrovia do São Francisco - AHSFRA \\
\hline Bacia do Paraguai & Administração da hidrovia do Paraguai - AHIPAR \\
\hline Bacia do Tietê-Paraná & Administração da hidrovia do Paraná - AHRANA \\
\hline Bacia do Sul & Administração da hidrovia do Sul - AHSUL \\
\hline
\end{tabular}




\section{ATIVIDADES E EMPREENDIMENTOS HIDROVIÁRIOS}

Existem diversos obstáculos que dificultam a navegação e impedem o desenvolvimento do transporte hidroviário interior no Brasil, aumentando o custo logístico e consequentemente diminuindo a competitividade da produção nacional face à concorrência externa. Dentre esses, se destacam a necessidade de melhoria da frota e da gestão administrativa; de decisão política na aplicação e priorização de recursos, técnicos e financeiro; e, em especial, de obras de infraestrutura. Não é possível fazer uma separação clara entre esses fatores, de forma que em qualquer análise que se deseje fazer é necessário contemplar um pouco dos demais. Considerando isso, este trabalho buscará passar por todos os aspectos envolvidos, mas sempre com o foco na infraestrutura da via navegável.

\subsection{Fases de Implantação de Sistemas de Transporte}

A implantação ou melhoramento de um sistema de transporte hidroviário pode ser dividido em fases distintas. A quantidade e denominação dessas fases são apresentadas com pequenas diferenças na literatura, conforme veremos a seguir.

Filippo (1999) distingue quatro fases na implantação de um sistema de transporte: planejamento, projeto, construção e operação (inclusive manutenção). Em seu trabalho, o autor analisa apenas as atividades e serviços das fases de implantação (ou construção) e operação, por apresentarem, em sua visão, maiores riscos de danos ambientais.

Já Santana (2008) relaciona cinco fases do projeto hidroviário: planejamento, implantação, operação, manutenção e desativação/descarte do projeto. Esse autor aborda as etapas do planejamento ambiental amarradas a cada uma dessas fases, conforme apresentado no Quadro 7.1, que sintetiza o desenvolvimento desse trabalho. 
Quadro 7.1 - Proposta Sintética para o desenvolvimento da tese de Santana (2008).

\begin{tabular}{|c|c|c|}
\hline $\begin{array}{c}\text { Nível de Administração } \\
\text { Hidroviária }\end{array}$ & $\begin{array}{c}\text { Fase de Projeto } \\
\text { Hidroviário }\end{array}$ & $\begin{array}{c}\text { Planejamento/Gestão } \\
\text { Ambiental }\end{array}$ \\
\hline Estratégico & Planejamento & Planejamento Ambiental \\
\hline Tático & Implantação & $\begin{array}{c}\text { Planejamento \& Gestão } \\
\text { Ambiental }\end{array}$ \\
\hline Operacional & $\begin{array}{c}\text { Operação } \\
\text { Manutenção } \\
\text { Desativação/Descarte* }^{*}\end{array}$ & $\begin{array}{c}\text { Planejamento \& Gestão } \\
\text { Ambiental }\end{array}$ \\
\hline
\end{tabular}

* O descarte é considerado devido aos projetos das embarcações, que são produtos e podem ser descartados.

Fonte: Santana (2008)

Tapajós (2002), no trabalho em que analisa projetos de hidrovias propostos para a Amazônia, observa que na prática existem seis etapas bem definidas para o delineamento. As etapas identificadas pelo autor são:

- 1a etapa - a justificativa: os projetos começam descrevendo o potencial econômico da região para a escolha de um modelo de projeto hidroviário;

- $2^{a}$ etapa - o modelo: o modelo escolhido dá ênfase à determinação das características físicas das infraestruturas e embarcações;

- 3a etapa - a otimização: é realizado um processo de otimização de embarcações e obras hidráulicas, em função da minimização do custo do transporte;

- 4를 - etapa - o orçamento: as estimativas das despesas para a implantação do projeto têm se limitado aos custos com as obras hidráulicas;

- $5^{\text {a }}$ etapa - a viabilidade: trata do aspecto econômico do projeto, que visa demonstrar o baixo custo da tonelada transportada de uma determinada produção potencial;

- 6a etapa - o ambiente: os impactos sobre os recursos naturais e o meio social são deixados para serem tratados por uma equipe externa ao projeto.

O autor supracitado abordou da seguinte forma a concepção de um projeto.

Um projeto inicia-se com uma ideia geral, mal definida, mesmo vaga, do que poderia ser uma solução adequada para uma necessidade sentida. Com o tempo essa ideia original, ou "concepção", é refinada e progressivamente detalhada até que contenha informação suficiente para ser transformada no produto, serviço ou processo real. A evolução da concepção à especificação detalhada pode ser dividida em etapas, com duas consequências importantes (SLACK, 1997). 
1 a consequência - redução de opções: quando é tomada uma decisão sobre o projeto, essa decisão reduz o número de opções que continuarão disponíveis na atividade de projeto. Isso contribui para a diminuição da incerteza, devido à diminuição do número de projetos alternativos das outras opções que foram descartadas. Portanto, a atividade de projeto pode ser considerada uma atividade que reduz progressivamente a incerteza;

$2^{\mathrm{a}}$ consequência - custos de mudanças: nas etapas preliminares de projeto, antes que demasiadas decisões fundamentais tenham sido tomadas, os custos de mudanças são relativamente baixos. À medida que se avança para etapas posteriores, as decisões interrelacionadas e cumulativas que são tomadas tornam-se cada vez mais dispendiosas. (TAPAJÓS, 2002)

Tapajós (2002) conclui que as seis etapas identificadas no delineamento dos atuais projetos não produziram as duas consequências desejáveis na evolução do projeto, pois terminaram sendo levados à discussão judicial como forma de determinar suas viabilidades, tendo como principais consequências as restrições sociais mais fortes e maiores custos para a implementação de mudanças. De acordo com o mesmo estudo, existem dois motivos para o custo final de um projeto ser sempre maior que o previsto. O primeiro é que o projeto é tratado de forma setorial, sendo que o processo de projeto inicia na subrotina que se pode denominar de "elaboração de detalhes", uma fase adiantada de projeto. O segundo motivo reside no fato de que na fase em que o projeto se torna público, fase de licenciamento, ele é analisado de forma sistêmica, havendo necessidade de voltar várias vezes às fases anteriores para complementar as informações exigidas.

Ainda segundo Tapajós (2002), um empreendimento hidroviário tem três fases críticas bem definidas: (1) fase de projeto (até o projeto básico), de domínio apenas do empreendedor; (2) fase de licenciamento, fase em que a sociedade toma conhecimento das intenções de uso dos recursos financeiros e ambientais; e (3) implantação/operação/manutenção, novamente de domínio do empreendedor. Das três fases descritas anteriormente, a de maior dificuldade é a relativa ao licenciamento, pois envolve o ponto de vista técnico/político de vários atores.

Atualmente, isso continua ocorrendo de forma sistemática. Acredita-se que planejamento e projeto mais bem desenvolvidos, considerando desde essas fases os aspectos ambientais, e participação ampla e antecipada dos diversos atores diminuiriam significativamente os problemas na fase de licenciamento. Outro ponto que deve ser observado refere-se às políticas 
públicas, que não devem ser resolvidas no licenciamento. Esse instrumento, da forma como está posto no regramento brasileiro, deve se limitar aos empreendimentos e atividades.

É de se destacar que o controle de vários dos impactos está relacionado ao planejamento territorial e às políticas públicas. O que deve ser observado no licenciamento é a inserção do empreendimento nesse contexto e não a solução de todos os problemas não resolvidos pelas esferas competentes, ou seja, a substituição das funções do Estado por um empreendedor.

Portanto, pode-se observar as seguintes fases: planejamento, projeto, execução das intervenções, operação e manutenção. Nesta pesquisa, a ênfase maior será dada nas intervenções e manutenção, por estarem mais relacionadas ao licenciamento ambiental, além do planejamento que é uma etapa anterior e de extrema importância. Cabe destacar que um bom planejamento ajudaria a evitar muitos dos problemas observados e, nesse sentido, uma proposta de planejamento para o setor hidroviário será apresentada neste trabalho.

No tocante à operação convém diferenciar os terminais, pontuais, das vias navegáveis, lineares. Nestas, diferenciam-se ainda os aspectos relacionados aos veículos e aqueles relacionados à infraestrutura. Essa separação se justifica tecnicamente, principalmente para o presente trabalho, pois esses elementos se encontram em esferas diferentes de governabilidade. Além disso, as ferramentas de gestão ambiental não devem se confundir com o procedimento de licenciamento ambiental. Em um paralelo com as rodovias, não considerar essas diferenças, seria como incorporar na construção do empreendimento, entre outras coisas, a discussão sobre as atividades lindeiras, tais como postos de combustíveis e comércio geral, além os aspectos da fabricação dos veículos que irão ali transitar.

\subsection{Atributos do $\mathrm{THI}$}

O transporte hidroviário interior é formado por um conjunto de atributos, que recebem diversas designações. Esses atributos, chamados de subsistemas operacionais básicos (FILIPPO, 1999), elementos (SANTANA, 2008) ou requisitos básicos (AZAMBUJA, 2005), bem como a forma como 
foram analisados pelos respectivos autores, serão abordados a seguir. 0 Quadro 7.2 permite uma melhor visualização das conceituações utilizadas por esses autores.

Quadro 7.2 - Atributos do transporte hidroviário interior.

\begin{tabular}{|c|c|c|c|c|c|c|}
\hline Autor & Denominação & \multicolumn{5}{|c|}{ Atributos } \\
\hline $\begin{array}{l}\text { Filippo } \\
\text { (1999) }\end{array}$ & $\begin{array}{c}\text { subsistemas } \\
\text { operacionais } \\
\text { básicos }\end{array}$ & vias & veículos & terminais & - & controles \\
\hline $\begin{array}{c}\text { Azambuja } \\
(2005)\end{array}$ & $\begin{array}{l}\text { requisitos } \\
\text { básicos }\end{array}$ & via & embarcações & terminais & $\begin{array}{l}\text { produto a ser } \\
\text { transportado }\end{array}$ & - \\
\hline $\begin{array}{l}\text { Santana, } \\
(2008)\end{array}$ & elementos & vias & embarcações & terminais & cargas & controles \\
\hline
\end{tabular}

Quadro compilado pelo autor

Filippo (1999) afirma que um sistema de transporte, de uma maneira geral, é composto por quatro subsistemas operacionais básicos (as vias, os veículos, os terminais e os controles) que interagem fortemente, exigindo uma visão sistêmica para sua otimização por meio de ações integradas sobre um conjunto de subsistemas.

Para Azambuja (2005), o desenvolvimento do transporte fluvial através das hidrovias relaciona-se intimamente com a existência de quatro requisitos básicos, quais sejam: a via propriamente dita, as embarcações, os terminais de carga e descarga e o produto a ser transportado. Além da via navegável, a viabilização do transporte fluvial requer a existência de cargas a serem movimentadas, de terminais e equipamentos destinados à carga e descarga de mercadorias, envolvendo aspectos operacionais e institucionais específicos da navegação fluvial, assim como a disponibilidade de embarcações de navegação interior.

Por sua vez, Santana (2008) faz uma relação dos elementos hidroviários (vias, embarcações, terminais, cargas e controles) com as fases do projeto e os possíveis efeitos ambientais nos meios físico, biótico e antrópico. A análise do autor é sintetizada no Quadro 7.3. 
Quadro 7.3 - Visão sistêmica dos elementos, fases do projeto e efeitos ambientais.

\begin{tabular}{|c|c|c|c|}
\hline Elementos & Implantação & Operação/Manutenção & Efeitos Ambientais \\
\hline Vias & $\begin{array}{l}\text { Obras e serviços } \\
\text { para melhoramento } \\
\text { ou criação de } \\
\text { condições de } \\
\text { navegabilidade }\end{array}$ & $\begin{array}{c}\text { Trafego de } \\
\text { embarcações } \\
\\
\text { Serviços de } \\
\text { manutenção e } \\
\text { conservação da via }\end{array}$ & $\begin{array}{l}\text { Efeitos diretos e } \\
\text { Indiretos nos meios } \\
\text { físico e biótico. }\end{array}$ \\
\hline Embarcações & $\begin{array}{l}\text { Serviços e atividades } \\
\text { para a construção de } \\
\text { embarcações } \\
\text { (atividades dos } \\
\text { estaleiros) }\end{array}$ & $\begin{array}{c}\text { Operações de carga e } \\
\text { descarga } \\
\text { Trânsito na via } \\
\text { Acidentes com derrame } \\
\text { de cargas } \\
\text { Geração de resíduos } \\
\text { Manutenção e } \\
\text { reparação }\end{array}$ & \\
\hline Terminais & $\begin{array}{l}\text { Obras e atividades } \\
\text { para a construção de } \\
\text { terminais e acessos }\end{array}$ & $\begin{array}{c}\text { Operações de carga e } \\
\text { descarga } \\
\text { Armazenagem de } \\
\text { cargas } \\
\text { Movimentação de } \\
\text { equipamentos e } \\
\text { veículos } \\
\text { Geração de resíduos } \\
\text { Manutenção de áreas } \\
\text { de acessos } \\
\text { Manutenção de } \\
\text { instalações } \\
\text { Manutenção de } \\
\text { embarcações }\end{array}$ & $\begin{array}{c}\text { Efeitos diretos e } \\
\text { indiretos na área de } \\
\text { influência com } \\
\text { incremento da } \\
\text { ocupação } \\
\text { demográfica e } \\
\text { econômica e às } \\
\text { mudanças } \\
\text { estruturais e } \\
\text { culturais das } \\
\text { populações. }\end{array}$ \\
\hline Cargas & $\begin{array}{l}\text { Sem efeito nesta } \\
\text { fase }\end{array}$ & $\begin{array}{c}\text { Transporte de cargas } \\
\text { perigosas e a } \\
\text { possibilidade de } \\
\text { acidentes com derrame }\end{array}$ & $\begin{array}{l}\text { Efeitos no meio } \\
\text { biótico. }\end{array}$ \\
\hline Controles & $\begin{array}{c}\text { Instalação de } \\
\text { dispositivos de } \\
\text { segurança, controle } \\
\text { e informação } \\
\text { Estabelecimento de } \\
\text { normas e } \\
\text { procedimentos para } \\
\text { operação e tráfego }\end{array}$ & $\begin{array}{c}\text { Manutenção dos } \\
\text { sistemas de informação } \\
\text { e controle } \\
\text { Ações de fiscalização } \\
\text { na via, embarcações e } \\
\text { terminais. }\end{array}$ & $\begin{array}{l}\text { Efeitos no meio } \\
\text { antrópico } \\
\text { (Segurança e } \\
\text { Informações) }\end{array}$ \\
\hline
\end{tabular}

Fonte: Santana (2008)

Cabe destacar que relacionados aos atributos do THI encontram-se os conceitos de navegação e navegabilidade. O primeiro se relaciona às embarcações, enquanto o ultimo à via, ou seja, à infraestrutura. 


\subsection{Vias Navegáveis Interiores}

No tópico anterior discorreu-se sobre o conjunto de atributos que compõem o sistema de transporte hidroviário interior, que são: vias, embarcações, terminais, cargas e controle.

É importante destacar que o planejamento deve levar em conta o conjunto de informações a fim de melhor compreender os processos e promover o planejamento mais realista possível, considerando, sempre que possível, todos os atributos do sistema, bem como, as dimensões técnica, econômica e socioambiental. No entanto, sem desconsiderar os demais, esta pesquisa se focará nas vias navegáveis interiores e, em especial, as intervenções necessárias para garantir a navegabilidade. Dessa forma, é necessário primeiramente conhecer melhor as características das vias e das intervenções inerentes à mesma.

\subsubsection{Denominações para Vias Navegáveis}

Alguns autores utilizam, como sinônimas, várias denominações para as vias navegáveis interiores, enquanto outros apresentam diferenças conceituais entre as diversas designações, em que se destacam duas, via navegável interior e hidrovia.

Cockrane (1992) apud Costa (1998) aponta uma diferença, do ponto de vista jurídico, entre hidrovia e via navegável. Segundo esse autor, enquanto a primeira é definida pelo critério de sua navegabilidade por embarcações de qualquer natureza, a via navegável é caracterizada não por sua aptidão intrínseca em permitir a navegação, mas por um ato declaratório do Poder Público.

Em termos comerciais o que caracteriza uma hidrovia é a sua capacidade de transporte de cargas. Uma hidrovia é mais ampla do que uma via navegável, é um eixo de transporte e requer a existência de infraestrutura e demanda obras de modo a retificar e aprofundar o canal navegável e permitir 0 fluxo do transporte seguro de cargas pelo seu leito (COSTA, 1998).

Segundo Almeida e Brighetti (1980), o conceito de "rio navegável" só tem sentido exato quando definido o tipo e dimensões da embarcação que 
deve trafegar. Santana (2008), por seu turno, adota um conceito de navegabilidade intimamente ligado ao aspecto econômico do transporte para definir dois conceitos básicos:

- Rio navegável - é aquele que permite o tráfego de embarcações;

- Rio comercialmente navegável - é aquele que permite o tráfego de embarcações com economicidade.

Por sua vez, Silva (2004) faz diferenciação entre três conceitos, rio naturalmente navegável, via navegável interior e hidrovia interior. O autor adota as seguintes definições:

- Rio naturalmente navegável - rio em estado natural que permite a navegação comercial;

- Via navegável interior - rio com alguma interferência de engenharia (sinalização, balizamento, etc.), propiciando melhores condições para a navegação comercial.

- Hidrovia interior - rio com maior ou menor grau de intervenção da engenharia, propiciando segurança à navegação a qualquer tempo para os veículos fluviais adequados aos padrões da via (sinalização, balizamento, carta eletrônica de navegação, navegação com GPS via satélite, estação de rádio controle, etc.), que atende a padrões específicos.

Por outro lado, Costa (1998) não faz distinção entre hidrovia ou via navegável e ainda insere uma nova denominação, a aquavia. Segundo esse autor, qualquer fluxo de água cujo trajeto ou percurso dê acesso à navegação é denominado de hidrovia, aquavia ou via navegável. O autor ressalta que, dependendo de suas características, o fluxo de água interior pode permitir a navegação livremente ou exigir melhoramentos, como retificações, sinalizações, derrocamentos, dragagens, barragens ou eclusas.

Almeida (2004) também não faz diferenciação entre hidrovia e via navegável. Para esse autor, hidrovia pode ser entendida como uma via navegável por onde circulam barcos, utilizando rios para estabelecer as rotas. Essa via navegável é uma faixa imaginária sobre o rio, que não existe fisicamente, mas que consta das cartas e mapas náuticos que as embarcações, conseguem obedecer com precisão, orientadas pelas boias e placas de sinalização. 
Este mesmo entendimento apresenta o Ministério dos Transportes - MT, para o qual, "hidrovia, aquavia, via navegável, caminho marítimo ou caminho fluvial são designações sinonímicas e hidrovia interior ou via navegável interior são denominações para os rios, lagos ou lagoas navegáveis", de acordo com as informações disponibilizadas em seu sitio eletrônico ${ }^{5}$. No entanto, o MT apresenta também um entendimento usual em relação ao termo hidrovia, conforme se pode observar no trecho a seguir.

Devido à falta de expressões como hidrovias interiores artificiais, para denominar aquelas que não eram navegáveis e que adquiriram essa condição em função de obras de engenharia, e hidrovias interiores melhoradas, para caracterizar as que tiveram suas condições de navegação ampliadas, usa-se genericamente a expressão hidrovias interiores para designar as vias navegáveis interiores que foram balizadas e sinalizadas para uma determinada embarcação tipo, isto é, àquelas que oferecem boas condições de segurança às embarcações, suas cargas e passageiros ou tripulantes e que dispõem de cartas de navegação. ${ }^{6}$

Entende-se que a diferenciação entre os termos rio naturalmente navegável, via navegável interior e hidrovia interior, conforme explanado por Silva (2004), é a mais adequada, pois expressa claramente relação com a infraestrutura da via. No entanto, para fins didáticos, neste trabalho, hidrovia interior ou via navegável interior serão consideradas sinônimas. Essa simplificação não traz nenhum prejuízo ao desenvolvimento desta pesquisa. Quando necessário apresentar diferenciações, essas serão explicitadas.

\subsubsection{Tipos de Rios}

No transporte hidroviário interior, a via navegável pode estar localizada em um rio, lago, lagoa ou outros cursos d'água interiores. Como as principais vias se encontram em rios, cabe fazer uma breve análise desses.

Em seu estado natural, os rios apresentam diversas características geográficas, tais como: i) os que correm em região plana e baixa velocidade da água e, no seu curso, apresentam uma série de meandros, e; ii) os que correm

\footnotetext{
5 Site do Ministério dos Transportes - Infraestrutura Hidroviária. Disponível em: <http://www.transportes.gov.br/>. Acesso em 05/04/2013.

6 idem
} 
em regiões com declive e que têm maior velocidade de escoamento seguem traçados mais regulares, embora tenham trechos mais acidentados.

Segundo Costa (1998), do ponto de vista morfológico é possível distinguir três tipos de rios que apresentam condições distintas para a realização da navegação:

- Rios de planície: são os caracterizados por uma declividade suave e regular e, por isso, os mais favoráveis para a navegação, como o Paraguai, o Amazonas e seus afluentes mais a montante, o Purus, o Madeira, o Iça e o Japurá.

- Rios de planalto: são os que apresentam uma sucessão de extensos estirões, com pouca declividade, interrompido por quedas que formam corredeiras e cachoeiras. No Brasil tem-se como exemplo, o Paraná e seus afluentes, o São Francisco e os efluentes do Amazonas mais a jusante, o Tapajós, Xingu e Trombetas;

- Rios costeiros: são os que possuem bacias vertentes reduzidas e leitos escavados em terrenos geralmente cristalinos. Os seus perfis longitudinais não são regulares e apresentam uma sucessão de estirões e travessões, que não oferecem, portanto, em sua maioria, qualquer condição natural que favoreça a navegação. São rios de pequena extensão, e descem diretamente do Planalto Central Brasileiro para o Oceano atlântico, estando junto à costa, desde o nordeste até o sul do País.

Ainda de acordo com Costa (1998), os rios podem ser divididos em três tipos para os parâmetros da navegação:

- Rios de corrente livre: são os que permitem a navegação naturalmente pelas suas próprias características, não havendo obras em seu curso. No entanto, as suas condições de navegabilidade podem ser melhoradas por regularização do leito - que modifica o traçado natural do rio, regularização de descarga - que implica na construção de barragens à montante do trecho navegável, ou dragagem - que mantém ou aprofunda o canal navegável; 
- Rios canalizados: são os que receberam barragens ou eclusas no seu percurso corrigindo as limitações de vazão e declividade, e reduzindo, com isso, a velocidade das águas nos sucessivos lagos formados;

- Canais: são vias artificiais e podem ser canais laterais - junto ao trecho de um rio cujo melhoramento é muito difícil, oneroso ou prejudicará terras de muitas benfeitorias, ou canais de interligação entre hidrovias.

\subsubsection{Caracterização das Vias}

Padovezi (2003) elencou as características físicas da via navegável de interesse para o transporte hidroviário e os fatores de interferência da passagem de embarcações com a via. Segundo o autor, do ponto de vista do sistema de transporte hidroviário, a via navegável apresenta as seguintes características físicas de interesse:

- profundidades do canal de navegação;

- velocidades de correntes;

- raios de curvaturas presentes no traçado do canal navegável;

- presença de pontos críticos ou com restrições (eclusas, pontes, canais estreitos, etc.);

- grau de exposição a ventos e possibilidade de formação de ondas por ação de ventos;

- suscetibilidade a alterações ambientais (possibilidade de desestabilização de margens, de interferência na fauna e flora submersas, etc.) provocadas pela passagem de embarcações;

- alterações das condições de navegabilidade ao longo do ano, em função do regime de águas;

- grau de manutenção das condições de navegabilidade ao longo do tempo (problemas de assoreamento, preservação de margens, etc.).

$O$ autor elencou ainda os fatores de interferência da embarcação com a via. De acordo com o referido trabalho, a passagem de embarcações em determinado trecho de rio, apresenta os seguintes fatores de interferência com a via: 
- formas, dimensões e velocidades das embarcações, gerando ondas, que podem afetar a estabilidade das margens e provocando efeito de sucção no fundo do rio, inclusive pela ação de propulsores, que provocam suspensão temporária de material sólido na água;

- potências instaladas e manobrabilidades das embarcações, que têm ligação direta com o nível de riscos de ocorrência de acidentes em trechos mais críticos da via;

- densidade do tráfego, podendo intensificar os efeitos das passagens de embarcações e aumentando riscos de ocorrência de acidentes;

- possibilidade de poluição da água por óleo ou por rejeitos sólidos, por erros operacionais ou por acidente.

\subsubsection{Classificação das Vias Navegáveis}

As vias navegáveis podem ser classificadas de diversas formas. O principal objetivo de um sistema de classificação deve ser 0 de assegurar 0 controle ordenado e eficiente, bem como, a manutenção de canais. Um sistema de classificação adequado pode basear-se em ambas as características, do canal e da embarcação, de acordo com características de um comboio-tipo. Cada classe de navegação interior tem sua embarcação (tipo, comprimento, raio de tração, carga e altura mínima sob pontes) ou comboio (formação e número de barcaças) padronizados, correspondente às condições de navegação. A classificação das vias navegáveis é variável nas diversas partes do mundo.

\subsubsection{Classificações Adotadas em Outros Países}

Como exemplo internacional de classificação de hidrovias pode-se citar a iniciativa da Associação Mundial de Infraestrutura de Transporte Aquaviário (PIANC). Em 1990, o Grupo de Trabalho formado pela PIANC (PIANC PTC-I) concluiu estudo sobre a padronização das dimensões das vias navegáveis interiores. Como resultado, foi proposta uma classificação atualizada de vias navegáveis interiores europeias. Nessa proposta, como nos sistemas de classificação anteriores, a classificação da via navegável está diretamente 
baseada na maior classe de navios que estão autorizados a navegar na hidrovia.

A classificação das vias navegáveis interiores europeias são um conjunto de padrões de operacionalidade de vias navegáveis (Quadro 7.4). O sistema de classificação atual foi padronizado pela Conferência Europeia dos Ministros dos Transportes (European Conference of Ministers of Transport ECMT), em 1992, por meio da Resolução ECMT nº 92/2. Essa classificação utiliza uma gama de dimensões que são denominadas como CEMT Classe IVII.

O tamanho para cada classe é limitado pelas dimensões das estruturas incluindo os pontos críticos no percurso, tais como eclusas e pontes. A Classe I corresponde ao histórico gabarito Freycinet, decretado na França em 1879. Os tamanhos maiores de classificação estão focados no transporte intermodal de containers em comboios de barcaças movidos por um empurrador. Em 2004, as normas foram ampliadas com quatro tamanhos menores (RA-RD) cobrindo embarcações de passeio, que tinham sido originalmente desenvolvidos e propostos através do PIANC. 
Quadro 7.4 - Classificação das Hidrovias Interiores na Europa.

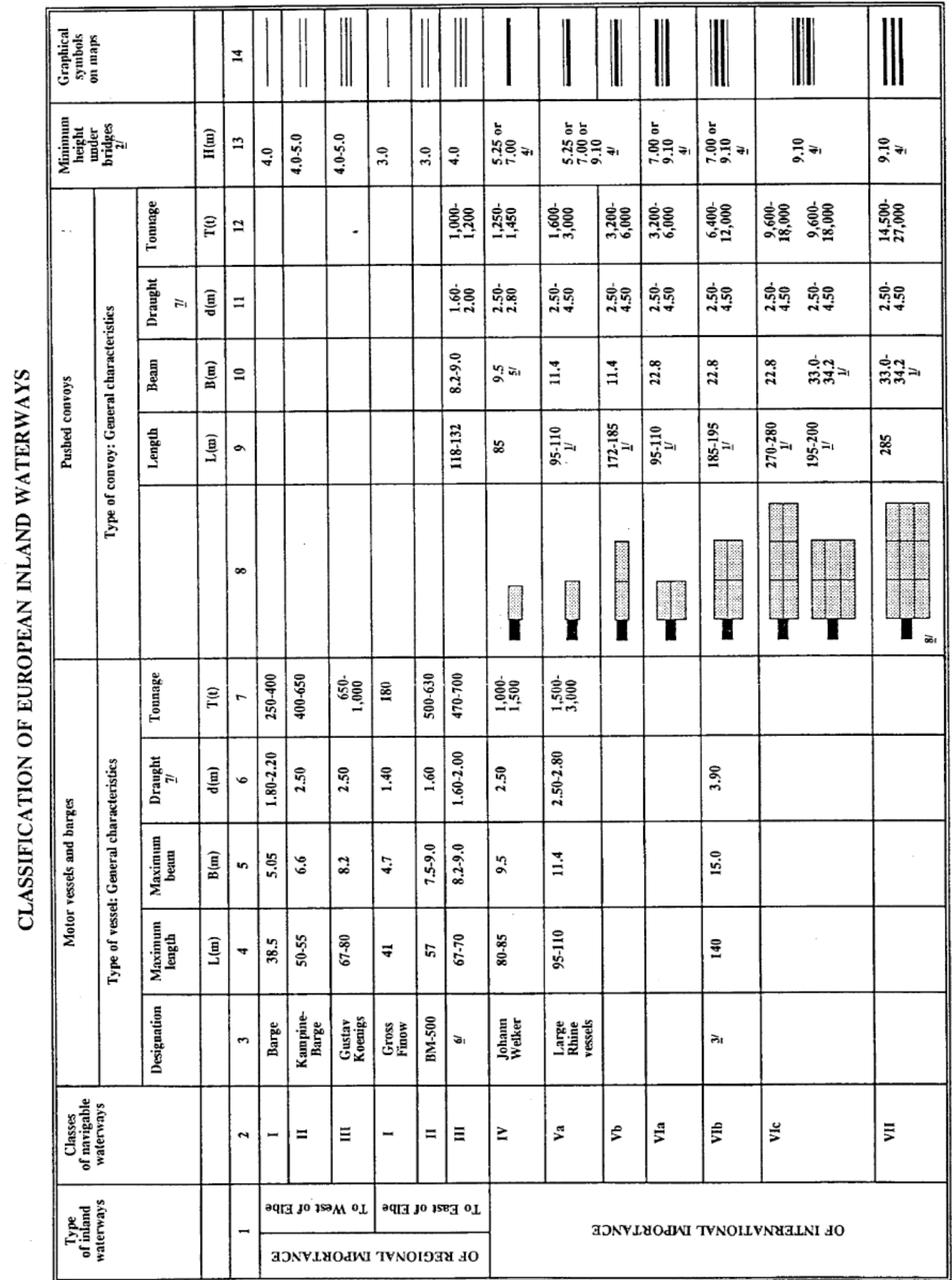

Fonte: Resolução ECMT 92/2

Nos Estados Unidos, a classificação é de responsabilidade da U.S. Army Corps of Engineers e segue as recomendações do PIANC, conforme Quadro 7.5 (SANTANA, 2008). 
Quadro 7.5 - Classificação das hidrovias segundo PIANC.

\begin{tabular}{|c|c|c|c|c|c|c|}
\hline \multirow[t]{2}{*}{ Classe } & \multicolumn{5}{|c|}{ Características Gerais dos Comboios } & \multirow{2}{*}{$\begin{array}{l}\text { Tirante de ar } \\
\mathrm{H}(\mathrm{m})\end{array}$} \\
\hline & $\begin{array}{l}\text { Arranjo } \\
\text { Chatas }\end{array}$ & $\mathrm{L}(\mathrm{m})$ & $\mathrm{B}(\mathrm{m})$ & $\mathrm{d}(\mathrm{m})$ & $\mathrm{T}(\mathrm{t})$ & \\
\hline $\mathrm{I}$ & - & - & - & - & - & 4,0 \\
\hline II & - & - & - & - & - & 4,5 \\
\hline III & - & - & - & - & - & 5,0 \\
\hline IV & $1 \times 1$ & 85 & 9,50 & 2,50 & 1.240 & 5,25 \\
\hline $\mathrm{V}$ a & $1 \times 1$ & $95-105$ & 11,40 & 2,80 & 1.850 & \multirow{2}{*}{7,0} \\
\hline $\mathrm{Vb}$ & $2 \times 1$ & $172-185$ & 11.40 & 2,80 & 3.700 & \\
\hline VI a & $2 \times 2$ & $185-195$ & 22,80 & 4,50 & $8.000-12.000$ & \multirow{3}{*}{9,10} \\
\hline \multirow[t]{2}{*}{ VI b } & $3 \times 2$ & 270 & 22,80 & 4,50 & $12.000-18000$ & \\
\hline & $2 \times 3$ & 195 & 34,20 & 4,50 & $12.000-18.000$ & \\
\hline
\end{tabular}

$\mathrm{L}=$ largura, $\mathrm{B}=$ Boca, $\mathrm{d}=$ calado, $\mathrm{T}=$ capacidade de carga, $\mathrm{H}=$ tirante de ar $=$ altura mínima debaixo das pontes

Fonte: Santana (2008)

\subsubsection{Classificação no Brasil}

No Brasil, não há uma diretriz única e clara sobre classificação das hidrovias. Azambuja (2005) faz referência às classes de hidrovias brasileiras, mas não há maiores detalhes de qual sistema de classificação é utilizado como referência. Segundo o autor, o País conta com cerca de 17.000 quilômetros de vias navegáveis consideradas como hidrovia de Classe A - via navegável interior disciplinada pelo poder público, desenvolvida, preparada e mantida para realizar o tráfego de uma "embarcação-tipo", em boas condições de navegabilidade durante todo o ano, com calados mínimos variados, de acordo com a bacia. O Quadro 7.6 apresenta a extensão da rede hidroviária total brasileira por bacia hidrográfica. 
Quadro 7.6 - Extensão da Rede Hidroviária Brasileira por Bacia Hidrográfica.

\begin{tabular}{|c|c|c|}
\hline Bacia Hidrográfica & Extensão $(\mathrm{Km})$ & Classe A $(\mathrm{Km})$ \\
\hline Amazônica & 18.300 & 9.760 \\
\hline Nordeste & 3.000 & 690 \\
\hline São Francisco & 4.100 & 1.370 \\
\hline Tocantins/Araguaia & 3.500 & 650 \\
\hline Paraguai & 2.800 & 1.320 \\
\hline Tietê/Paraná & 4.800 & 1.750 \\
\hline Sul/Sudeste & 1.300 & 1.000 \\
\hline
\end{tabular}

Fonte: Lima (1990) apud Azambuja (2005)

Em 1989, a PORTOBRAS (Empresa de Portos do Brasil S. A.) contratou a elaboração do Plano Nacional de Vias Navegáveis Interiores - PNVNI. O objetivo era dotar o setor de um planejamento da infraestrutura que regulamentasse e atualizasse a Lei do Plano Nacional de Viação - PNV. O planejamento foi abandonado em meio à extinção da Empresa, que ocorreu pelo Decreto ํㅜ 99.226, de 27 de abril de 1990.

Santana (2008) relata que a extinta PORTOBRÁS, com o trabalho Rede Hidroviária Brasileira, em 1988, estudou e classificou as principais vias navegáveis de todas as bacias hidrográficas brasileiras, que deu base para 0 PNVNI. Esse trabalho não traz a palavra "classes", mas sim o termo "gabaritos" das hidrovias e tem uma classificação inversa à classificação europeia, ou seja, quanto maior é o número do gabarito, menor é a capacidade da via. Nesse sistema, o parâmetro utilizado para classificação é a profundidade mínima garantida com $75 \%$ de permanência no tempo em um determinado trecho do rio, como pode ser observado no Quadro 7.7. 
Quadro 7.7 - Classificação das vias navegáveis segundo PNVNI (1989).

\begin{tabular}{|c|c|c|c|}
\hline \multirow{2}{*}{ Gabarito } & Características & \multicolumn{2}{|c|}{ Profundidade } \\
\cline { 3 - 4 } I & $\begin{array}{c}\text { "Especial" } \\
\text { Para rios onde a navegação } \\
\text { marítima tenha acesso }\end{array}$ & - & - \\
\hline II & $\begin{array}{c}\text { Para rios de grande potencial de } \\
\text { navegação }\end{array}$ & $>2,50$ & $2,00-1,50$ \\
\hline III & Para do rios de potencial médio de & & $1,50-1,20$ \\
\hline transporte & Para rios de menor potencial & $>2,00$ & $1,20-0,80$ \\
\hline V & $\begin{array}{c}\text { Para rios interrompidos ou onde a } \\
\text { navegação tenha possibilidade } \\
\text { remota }\end{array}$ & - & - \\
\hline
\end{tabular}

Fonte: Plano Nacional de Vias Navegáveis Interiores (1989) apud Brasil (2005)

Desde então, não houve grandes evoluções no sistema de classificação de hidrovias no Brasil, apesar de toda a importância dessas definições para o planejamento do próprio setor hidroviário e para outros setores. Essa definição de classes está incluída no objetivo 0283 do PPA 2012-2015. Esse item do PPA tem como objetivo estruturar o planejamento, a gestão, a operação e o controle do transporte hidroviário, dando continuidade à regulação do setor e garantindo a movimentação de pessoas e bens, em cumprimento a padrões de eficiência, segurança, conforto, regularidade, pontualidade e modicidade nos fretes e tarifas. Para esse objetivo foram estipuladas as seguintes metas:

- Definir classes de hidrovias;

- Definir comboios tipo para os corredores hidroviários;

- Elaborar 07 Planos para consolidar e estruturar o planejamento, a gestão, a operação e o controle do transporte hidroviário.

\subsection{Infraestrutura Hidroviária}

Frequentemente os rios oferecem restrições à navegação franca, sendo que, mesmo nos grandes rios pode haver dificuldades de tráfego em certos trechos. Portanto, são necessárias intervenções para garantir a navegabilidade e a segurança da navegação. 
De acordo com Silva (2004), poucos são os cursos d'água que em condições naturais apresentam trechos satisfatoriamente longos com características que possibilitem o tráfego contínuo e seguro de embarcações de porte capazes de realizar transporte de cargas com caráter comercial. Por outro lado, alguns rios, como o Amazonas, Madeira, São Francisco, Paraná, Paraguai e outros, apresentam-se naturalmente navegáveis, isto é, são rios em estado natural que permitem a navegação comercial por extensões de centenas ou mesmo de mais de um milhar de quilometro. Assim, podem-se observar três tipos de vias navegáveis. Os três tipos de vias são:

- Vias navegáveis naturais - são aquelas que naturalmente podem garantir profundidades adequadas à navegação mesmo durante a estiagem, necessitando apenas de atividades rotineiras e de manutenção, como dragagem, limpeza do leito (retirada de galhos e troncos e balseiros), sinalização e balizamento.

- Vias navegáveis naturais com melhoramentos - são aquelas que para alcançar a situação de navegabilidade, requerem obras de melhoramentos. Essas podem ser melhoramentos gerais, regularização do leito, obras de estabilização e proteção das margens, dragagens e canalização.

- Vias navegáveis artificiais - são os canais construídos onde não havia cursos d'água, inteiramente artificiais.

Para aproveitar o imenso potencial hídrico ainda não devidamente explorado, são necessárias intervenções a fim de proporcionar navegabilidade e garantir a segurança da navegação. A seguir, são apresentadas as diferentes intervenções nas hidrovias para a solução ou mitigação dos distintos fatores que afetam negativamente sua navegabilidade. 


\subsubsection{Intervenções Hidroviárias}

Segundo Santana (2008), os rios de corrente livre podem ter suas condições de navegabilidade sensivelmente melhoradas por meio de técnicas ou processos que podem ser usados isolada ou conjuntamente. Por outro lado, os rios canalizados são aqueles formados, principalmente, pelos lagos dos reservatórios das usinas hidrelétricas e obras de transposição de desnível, geralmente de uso múltiplo das águas, com a hidrogeração de energia elétrica, pesca, abastecimento, irrigação, turismo, lazer e navegação. Existem também os canais artificiais, cuja construção pode se dar de duas maneiras:

- Canais Laterais - para contorno de obstáculos naturais como rochas no leito do rio, baixo calado, pouca curvatura, etc.

- Canais de "Ponto de Partilha" - para a ligação de bacias hidroviárias ou hidrográficas.

O referido autor apresenta um resumo dos tipos de vias navegáveis, principais técnicas utilizadas para melhorar a navegabilidade e as obras e métodos utilizados para cada técnica, conforme Quadro 7.8. 
Quadro 7.8 - Tipos de vias navegáveis e as técnicas para melhorar a navegabilidade.

\begin{tabular}{|c|c|c|c|}
\hline $\begin{array}{l}\text { Tipos de } \\
\text { vias } \\
\text { navegáveis } \\
\text { interiores }\end{array}$ & $\begin{array}{l}\text { Melhoramentos } \\
\text { das vias } \\
\text { navegáveis }\end{array}$ & Técnicas ou Processos & Obras ou Métodos \\
\hline \multirow{7}{*}{$\begin{array}{l}\text { Rios de } \\
\text { correntes } \\
\text { livres }\end{array}$} & \multirow{7}{*}{$\begin{array}{l}\text { Trabalhos de } \\
\text { Regularização }\end{array}$} & $\begin{array}{l}\text { Limpeza do Leito } \\
\text { (retirada de troncos e } \\
\text { árvores caídas no leito) }\end{array}$ & $\begin{array}{l}\text { Limpeza com instrumentos } \\
\text { e/ou veículos }\end{array}$ \\
\hline & & $\begin{array}{c}\text { Fechamento de Braços } \\
\text { Secundários } \\
\text { (concentração das águas em } \\
\text { um único leito) }\end{array}$ & $\begin{array}{l}\text { Construção de diques, } \\
\text { barragens }\end{array}$ \\
\hline & & $\begin{array}{c}\text { Obras de Retificação do } \\
\text { Leito } \\
\text { (para reduzir sinuosidades e } \\
\text { distâncias) }\end{array}$ & Diques e Espigões \\
\hline & & $\begin{array}{l}\text { Contração Lateral do Leito } \\
\text { (para o aumento da } \\
\text { profundidade) }\end{array}$ & $\begin{array}{c}\text { Construção de diques } \\
\text { (disposição longitudinal) e/ou } \\
\text { construção de espigões } \\
\text { (disposição transversal) }\end{array}$ \\
\hline & & $\begin{array}{c}\text { Modelagem do Leito - } \\
\text { Método de Girardon } \\
\text { (aplicação das leis de } \\
\text { Fargue) }\end{array}$ & $\begin{array}{l}\text { Construção de espigões, } \\
\text { diques e soleiras de fundo }\end{array}$ \\
\hline & & $\begin{array}{c}\text { Obras de Dragagem } \\
\text { (remoção de solo aluvionar) }\end{array}$ & $\begin{array}{c}\text { Métodos em função dos tipos } \\
\text { das dragas }\end{array}$ \\
\hline & & $\begin{array}{l}\text { Obras de Derrocamentos - } \\
\text { (remoção de leito rochoso) }\end{array}$ & Métodos não explosivos \\
\hline $\begin{array}{c}\text { Rios } \\
\text { Canalizados }\end{array}$ & $\begin{array}{l}\text { Trabalhos de } \\
\text { canalização }\end{array}$ & $\begin{array}{c}\text { (remoção de leito rochoso) } \\
\text { Construção de barragens } \\
\text { fixas ou móveis } \\
\text { (com obras de transposição } \\
\text { de desnível) }\end{array}$ & Barragens e eclusas \\
\hline \multirow{2}{*}{ Canais } & \multirow{2}{*}{$\begin{array}{l}\text { Construção de } \\
\text { canais } \\
\text { artificiais }\end{array}$} & Canais Laterais & \multirow{2}{*}{ Canais longitudinais } \\
\hline & & $\begin{array}{c}\text { Canais de "Ponto de } \\
\text { Partilha" }\end{array}$ & \\
\hline
\end{tabular}

Fonte: Santana (2008)

Classificação para as técnicas e processos para melhoramento das vias navegáveis, semelhante à apresentada por Santana (2008), é realizada por Fillipo (1999). Segundo esse autor, para servirem como uma via de transporte, os cursos d'água necessitam quase sempre de melhoramentos que podem ser em menores ou maiores proporções, além daqueles destinados ao melhoramento das condições de segurança do tráfego, como os serviços de balizamento e de sinalização da via navegável.

Os melhoramentos de menores proporções são aqueles que têm por objetivo facilitar e manter as condições de circulação das embarcações que já trafegam em um determinado trecho de um curso d'água sem, contudo, permitir a adoção de novos tipos de embarcações ou de comboios (FILIPPO, 1999). Fazem parte deste tipo de melhoramento, por exemplo: retirada de obstáculos 
visíveis ou invisíveis, como troncos ou pedras isoladas; aprofundamento por dragagem de uma soleira (baixio) formada numa cheia, um curso d'água não canalizado, e; melhoria das condições de acesso dos barcos nas entradas de eclusas e de terminais.

Por outro lado, o autor aponta que os melhoramentos de maiores proporções no curso d'água são aqueles que estabelecem condições de navegação que antes não existiam ou que aumentam a capacidade e o porte das embarcações que circulam em uma via, como: canalização de um curso d'água para aumentar a profundidade disponível; obras de grandes derrocamentos; execução de canais laterais artificiais dotados de eclusas, para permitir, por exemplo, a travessia de uma zona de corredeiras; e, retificação de canais de navegação.

Filippo (1999) lembra que no Brasil são bastante utilizados os serviços e obras de dragagem e derrocamento, existindo também exemplos de canalização nos principais rios das bacias do Sudeste (rios Jacuí e Taquari) e do Paraná (rios Paraná e Tietê). Ainda de acordo com o autor, em relação à execução de canais artificiais, existem estudos antigos no País para interligação de algumas bacias principais, porém, devido aos altos investimentos demandados, tais ideias ficaram somente no papel.

Diniz (2007) classifica essas obras e serviços como gerais ou de normalização, retificação de meandros, regularização de leitos, derrocamento, dragagem, construção de canais artificiais, barragens e sinalização/balizamento. A classificação proposta pelo autor é apresenta na Figura 7.1. 


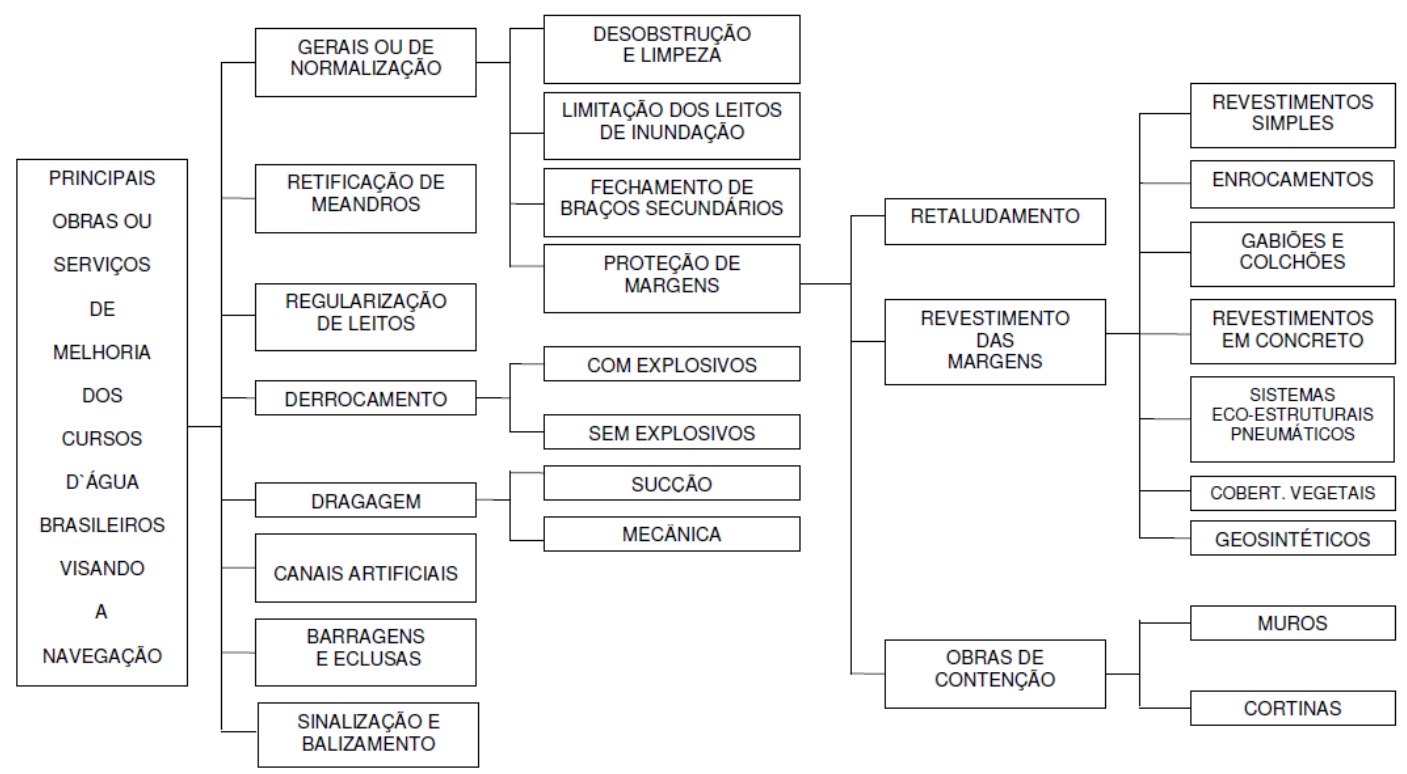

Figura 7.1 - Diagrama das obras e serviços para melhoramento em cursos d'água brasileiros.

Fonte: DINIZ (2007)

Diniz (2007) cita ainda as seguintes obras e atividades necessárias para promover a navegabilidade dos rios brasileiros:

- Desobstrução e retirada de vegetação flutuante, travessões rochosos e pedrais, principalmente na época de vazante, constantemente realizado praticamente em todos os rios;

- Proteção de pilares e ampliação dos vãos de pontes rodo e ferroviárias que limitam a passagem de comboios fluviais, como realizado na Hidrovia Tietê-Paraná;

- Construção de sistemas de eclusas para transposição de desníveis nos trechos de rios como as de Santo Antônio, Jirau, Tucuruí e Lajeado, nos rios Amazonas, Tocantins, Araguaia e Jupiá em projeto no rio Paraná;

- Dragagens de manutenção e derrocamentos de forma a permitir uma profundidade mínima do trecho navegável, principalmente na época de águas baixas, como as constantemente realizadas no rio Paraguai, na bacia do Sul e no rio São Francisco;

- Realização de levantamentos topo-batimétricos, sinalização e adoção de um sistema de navegação em tempo real, como o realizado no rio Paraguai, para garantia de segurança à navegação.

(DINIZ, 2007) 
No estudo de Carvalho (2008), quando elencadas as obras e os serviços a serem executados, fica explícita a divisão em dois tipos de intervenções: construção de um novo canal e melhoria das condições de navegação do rio, conforme se verifica nos trechos reproduzidos a seguir:

Quanto à construção do canal de ligação dos rios Anajá e Atuá: desmatamento e limpeza do terreno; escavação a seco, com construção simultânea de diques de contenção; mobilização e desmobilização de equipamentos de construção e de instalações; proteção dos diques e taludes do canal com vegetação; dragagem; execução de bueiros.

Quanto à melhoria das condições de navegação dos dois rios: dragagem; mobilização e desmobilização de equipamentos. (CARVALHO, 2008)

Silva (2004) entende por obras hidroviárias, a intervenção de engenharia, direta e indireta no rio, de modo a resultar em obras civis, que permitam a implantação e operação de uma hidrovia.

Com base na classificação de Van Raalten (1981), Silva (2004) faz uma proposta de classificação para os tipos de obras hidroviárias, adequando aquela à realidade brasileira. A classificação proposta pelo autor divide a obras em três grupos: gerais ou de normalização; canais artificiais e obras de canalização dos cursos d'água. As gerais ou de normalização são obras locais visando problemas específicos, do tipo: trecho raso ou curva muito brusca ou margem instável; de modo geral visam o melhoramento dos cursos d'água e não influem no regime hidráulico ou morfológico do rio. Dificilmente são usadas sozinhas, sendo comum a sua utilização em conjunto com os outros tipos de obras. Segundo o autor, as principais obras de normalização são: desobstrução e limpeza; limitação dos leitos de inundação; fechamento de braços secundários; proteção das margens; retificação de rios meandrantes; regularização dos leitos; derrocamento e dragagem.

As atividades e empreendimentos hidroviários utilizados e as tipologias propostas na literatura para classificá-los são apresentadas de forma compilada no Quadro 7.9. Como se pode observar, todas as classificações apresentadas se baseiam estritamente na obra de engenharia. 
A tipificação das atividades e empreendimentos com base em suas características gerais, não apenas na obra de engenharia, é importante para o desenvolvimento do presente trabalho. A abordagem em tipologias é necessária por cada um merecer controles e procedimentos diferenciados. Nesse sentido, propomos neste trabalho a divisão das atividades hidroviárias em quatro grupos. Esses grupos são: implantação de canais, intervenções de implantação, intervenções de melhoramento e intervenções de manutenção. Além desses quatro grupos têm-se ainda: obras de canalização, os serviços de sinalização de balizamento e os serviços de limpeza. Esses grupos serão detalhados no Capitulo 9. 
Quadro 7.9 - Compilação das atividades e empreendimentos hidroviários.

\begin{tabular}{|c|c|c|c|c|c|c|c|c|c|c|c|c|c|c|c|c|c|c|c|}
\hline Autor & Tipos & 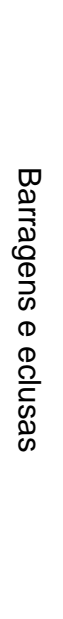 & 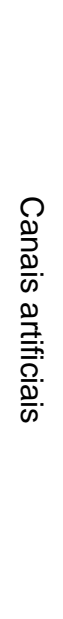 & 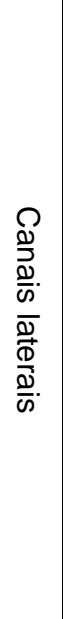 & 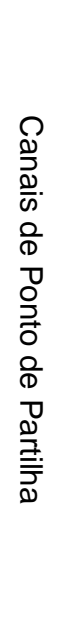 & 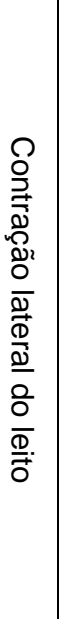 & 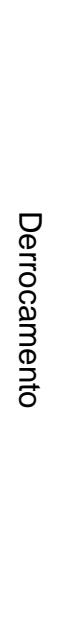 & 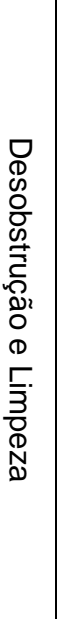 & 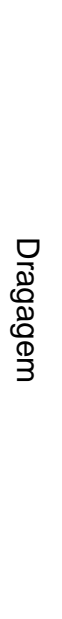 & 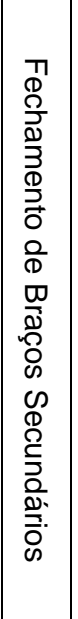 & 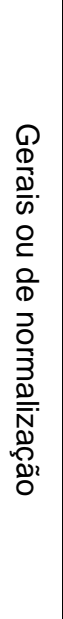 & 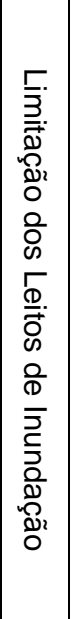 & $\begin{array}{l}\bar{\Gamma} \\
\overline{3} \\
\bar{D} \\
\mathbb{N} \\
\mathbb{N} \\
\frac{0}{0} \\
\frac{\bar{D}}{\bar{\sigma}}\end{array}$ & 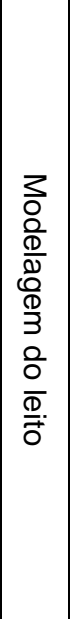 & 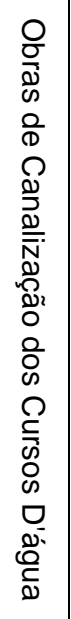 & 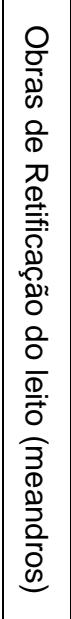 & 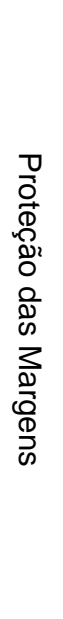 & 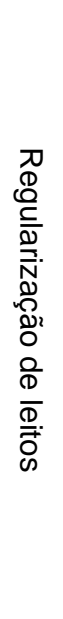 & 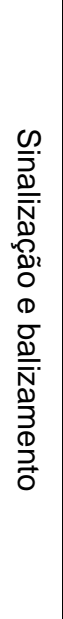 \\
\hline \multirow{5}{*}{$\begin{array}{c}\text { VAN } \\
\text { RAALTEN } \\
\text { (1981) apud } \\
\text { SILVA } \\
(2004)\end{array}$} & Obras simples & & & & & & $\mathrm{x}$ & & $\mathrm{x}$ & & & & & & & & & & \\
\hline & $\begin{array}{l}\text { Obras de fixação do leito e proteção de estruturas que com a } \\
\text { aplicação de métodos construtivos tradicionais }\end{array}$ & & & & & & & & & & & & & & & & $\mathrm{x}$ & & \\
\hline & Obras de regularização de vazão & $\mathrm{x}$ & & & & & & & & & & & & & & & & & \\
\hline & Obras de canalização como regularização do leito de rio & & $\mathrm{x}$ & $\mathrm{x}$ & $\mathrm{x}$ & & & & & & & & & & & & & & \\
\hline & Serviços de sinalização e balizamento & & & & & & & & & & & & & & & & & & $\mathrm{x}$ \\
\hline \multirow{8}{*}{$\begin{array}{c}\text { FILIPPO } \\
\text { (1999) }\end{array}$} & \multirow{6}{*}{ Trabalhos de regularização } & & & & & & & & & $x$ & & & & & & & & & \\
\hline & & & & & & & & & $\mathrm{x}$ & & & & & & & & & & \\
\hline & & & & & & $\mathrm{x}$ & & & & & & & & & & & & & \\
\hline & & & & & & & & & & & & & & $x$ & & & & & \\
\hline & & & & & & & & & $\mathrm{x}$ & & & & & & & & & & \\
\hline & & & & & & & $\mathrm{x}$ & & & & & & & & & & & & \\
\hline & Trabalhos de canalização & $\mathrm{x}$ & & & & & & & & & & & & & & & & & \\
\hline & Construção de canais artificiais & & & $\mathrm{x}$ & & & & & & & & & & & & & & & \\
\hline
\end{tabular}




\begin{tabular}{|c|c|c|c|c|c|c|c|c|c|c|c|c|c|c|c|c|c|c|c|}
\hline \multirow[t]{3}{*}{ Autor } & \multirow[t]{2}{*}{ Tipos } & \multirow[t]{2}{*}{ 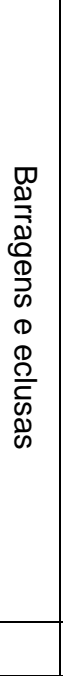 } & \multirow[t]{2}{*}{ 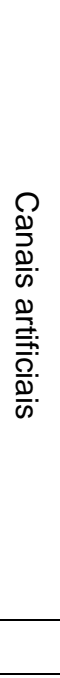 } & \multirow[t]{2}{*}{ 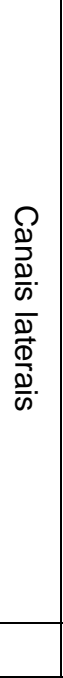 } & \multirow[t]{2}{*}{ 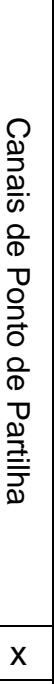 } & \multirow[t]{2}{*}{ 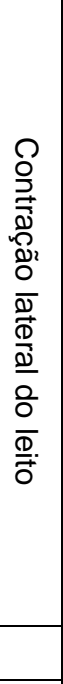 } & \multirow[t]{2}{*}{ 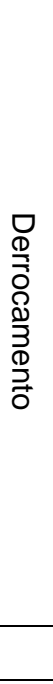 } & \multirow[t]{2}{*}{ 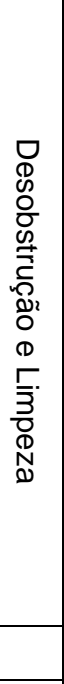 } & \multirow[t]{2}{*}{ 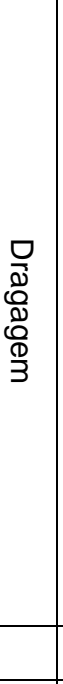 } & 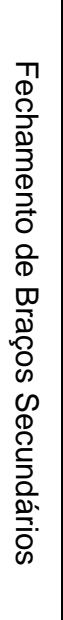 & \multirow[t]{2}{*}{ 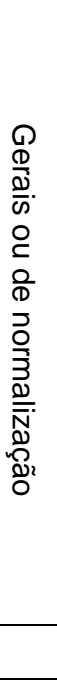 } & 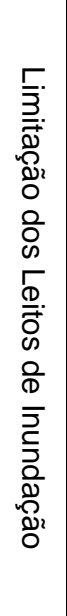 & \multirow[t]{2}{*}{ 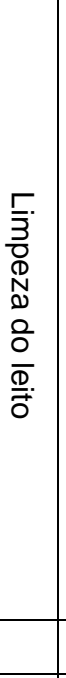 } & \multirow[t]{2}{*}{$\begin{array}{l}3 \\
\frac{2}{0} \\
\frac{0}{D} \\
\frac{D}{0} \\
\mathbb{D} \\
3 \\
\frac{0}{0} \\
\bar{D} \\
\overline{0}\end{array}$} & 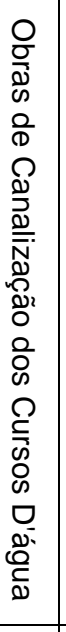 & 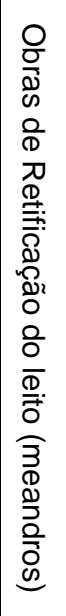 & 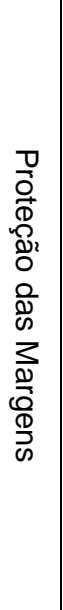 & 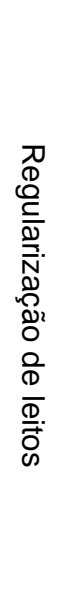 & 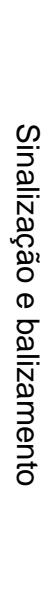 \\
\hline & & & & & & & & & & & & & & & & & & & \\
\hline & Serviços de sinalização e balizamento & & & & & & & & & & & & & & & & & & $x$ \\
\hline \multirow{10}{*}{$\begin{array}{l}\text { SILVA } \\
(2004)\end{array}$} & \multirow{4}{*}{ Gerais ou de Normalização } & & & & & & & $\mathrm{x}$ & & & & & & & & & & & \\
\hline & & & & & & & & & & & & $x$ & & & & & & & \\
\hline & & & & & & & & & & $x$ & & & & & & & & & \\
\hline & & & & & & & & & & & & & & & & & $\mathrm{x}$ & & \\
\hline & Retificação de rios meandrantes & & & & & & & & & & & & & & & $\mathrm{x}$ & & & \\
\hline & Regularização dos Leitos & & & & & & & & & & & & & & & & & $x$ & \\
\hline & Derrocamento & & & & & & $\mathrm{x}$ & & & & & & & & & & & & \\
\hline & Dragagem & & & & & & & & $x$ & & & & & & & & & & \\
\hline & Canais Artificiais & & $\mathrm{x}$ & & & & & & & & & & & & & & & & \\
\hline & Obras de Canalização dos Cursos D'água & & & & & & & & & & & & & & $\mathrm{x}$ & & & & \\
\hline \multirow{3}{*}{$\begin{array}{l}\text { DINIZ } \\
(2007)\end{array}$} & \multirow{3}{*}{ Obras ou serviços de melhoria } & & & & & & & & & & $x$ & & & & & & & & \\
\hline & & & & & & & & & & & & & & & & $\mathrm{x}$ & & & \\
\hline & & & & & & & & & & & & & & & & & & $x$ & \\
\hline
\end{tabular}




\begin{tabular}{|c|c|c|c|c|c|c|c|c|c|c|c|c|c|c|c|c|c|c|c|}
\hline Autor & Tipos & 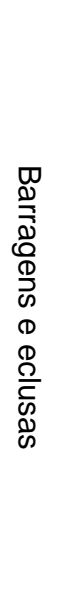 & 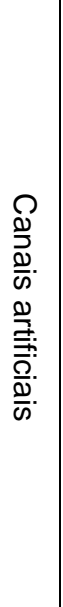 & 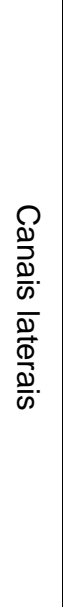 & 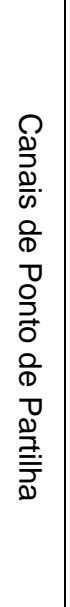 & 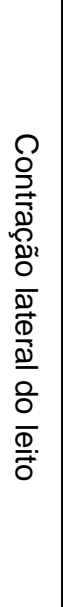 & 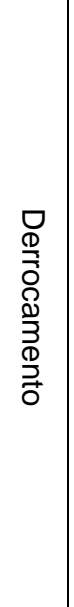 & 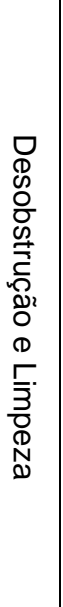 & 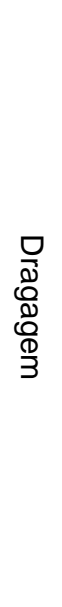 & 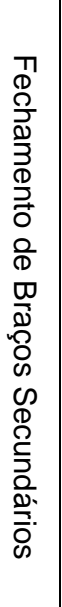 & 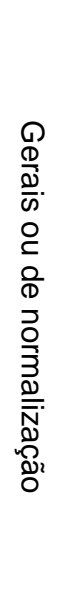 & 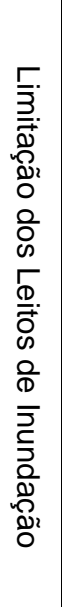 & 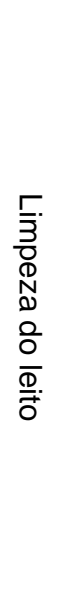 & 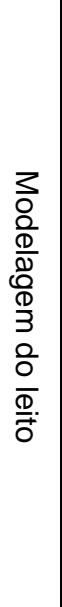 & 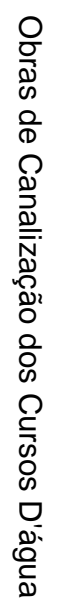 & 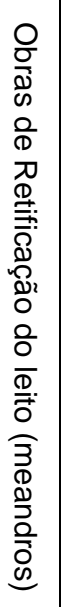 & 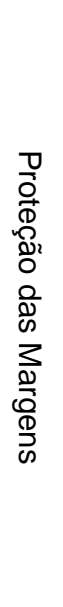 & 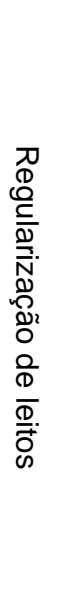 & 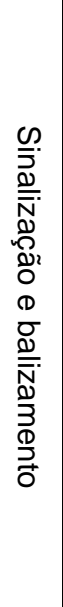 \\
\hline & & & & & & & $\mathrm{x}$ & & & & & & & & & & & & \\
\hline & & & & & & & & & $\mathrm{x}$ & & & & & & & & & & \\
\hline & & & $\mathrm{x}$ & & & & & & & & & & & & & & & & \\
\hline & & $\mathrm{x}$ & & & & & & & & & & & & & & & & & \\
\hline & & & & & & & & & & & & & & & & & & & $\mathrm{x}$ \\
\hline \multirow{10}{*}{$\begin{array}{c}\text { SANTANA } \\
(2008)\end{array}$} & \multirow{7}{*}{ Trabalhos de regularização } & & & & & & & & & & & & $\mathrm{x}$ & & & & & & \\
\hline & & & & & & & & & & $\mathrm{x}$ & & & & & & & & & \\
\hline & & & & & & & & & & & & & & & & $\mathrm{x}$ & & & \\
\hline & & & & & & $\mathrm{x}$ & & & & & & & & & & & & & \\
\hline & & & & & & & & & & & & & & $\mathrm{x}$ & & & & & \\
\hline & & & & & & & & & $\mathrm{x}$ & & & & & & & & & & \\
\hline & & & & & & & $\mathrm{x}$ & & & & & & & & & & & & \\
\hline & Trabalhos de canalização & $\mathrm{x}$ & & & & & & & & & & & & & & & & & \\
\hline & \multirow{2}{*}{ Construção de canais artificiais } & & & $\mathrm{x}$ & & & & & & & & & & & & & & & \\
\hline & & & & & $x$ & & & & & & & & & & & & & & \\
\hline
\end{tabular}




\begin{tabular}{|c|c|c|c|c|c|c|c|c|c|c|c|c|c|c|c|c|c|c|c|}
\hline Autor & Tipos & 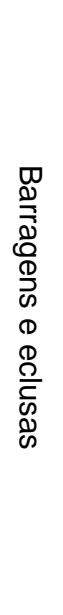 & 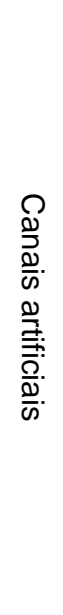 & 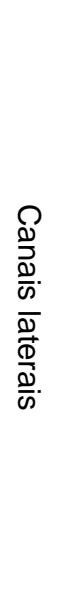 & 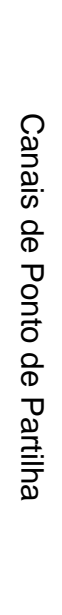 & 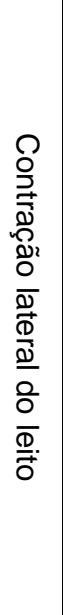 & 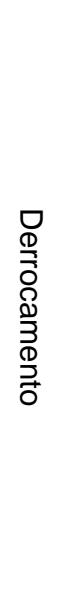 & 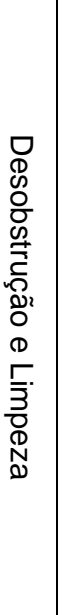 & $\begin{array}{l}\text { D } \\
\mathbb{N} \\
\mathbb{0} \\
\mathscr{0} \\
\mathbb{0} \\
3\end{array}$ & 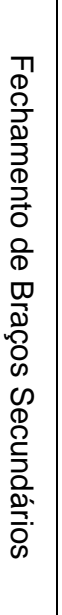 & 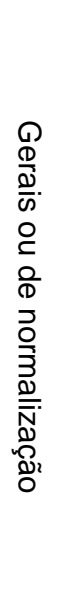 & 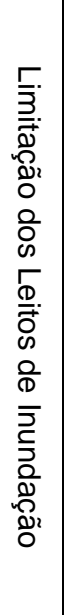 & 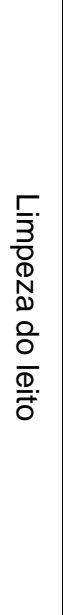 & 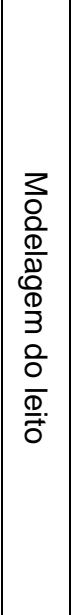 & 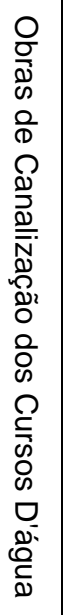 & 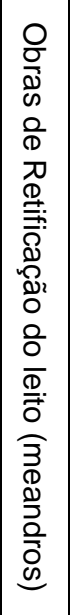 & 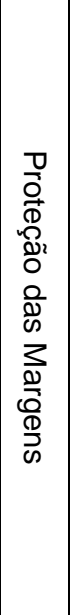 & 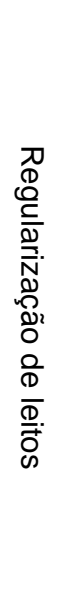 & 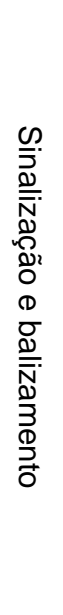 \\
\hline \multirow{2}{*}{$\begin{array}{c}\text { CARVALHO } \\
(2008)\end{array}$} & Construção do canal & & $x$ & & & & & & & & & & & & & & & & \\
\hline & Melhoria das condições de navegação & & & & & & & & $\mathrm{x}$ & & & & & & & & & & \\
\hline
\end{tabular}




\subsection{Descrição das Intervenções Hidroviárias ${ }^{7}$}

Esta seção apresenta descrição relativa às principais intervenções hidroviárias: fechamento de braços secundários, obras de retificação do leito, contração lateral do leito e limitação do leito de inundação, regularização dos leitos, dragagem, derrocamento, canalização, construções de canais artificiais, serviços de sinalização e balizamento, desobstrução e limpeza do leito e manutenção. Cabe esclarecer que, muitas vezes, diferentes intervenções são realizadas conjuntamente para atingir a condição de navegabilidade desejada.

\subsubsection{Fechamento de Braços Secundários}

Esta técnica consiste em concentrar a água de estiagem em um único braço por meio do fechamento dos demais braços, considerados como secundários, empregando-se para isso diques ou barragens transversais ao leito. Pode ser empregada uma única barragem para suportar o desnivelamento total existente no curso d'água entre as duas pontas da "ilha" formada, ou a construção de uma série de barragens escalonadas, atendendo cada uma a um determinado desnível. A concentração das águas em um único leito permite aumentar a profundidade, principalmente no período de vazões mínimas, quando a navegação se torna crítica.

Segundo Silva (2004), o fechamento é efetuado por meio de obras permeáveis ou não, geralmente com altura até a cota mínima de navegação, ficando submersos para vazões maiores. Essas obras são soleiras de fundo ou pequenas barragens que podem ser transpostas e, portanto, devem ter a superfície protegida para evitar a sua destruição. Podem ser construídas em enrocamento de pedras ou terra, com proteção na superfície ou ainda em estaqueamento simples ou duplo. Essas obras alteram o regime do rio na estiagem, pois ocorre a concentração das vazões em um único canal, podendo acarretar erosões no mesmo e a deposição de materiais transportados no(s) trecho(s) de jusante. Em geral, as alterações ambientais são locais e devem ser mitigadas com a execução de obras

\footnotetext{
${ }^{7}$ Grande parte do conteúdo desta seção foi baseada na obra de Filippo (1999). Outros autores, que fizeram o detalhamento, também se basearam nesta mesma obra. Assim, não serão feitas as referencias ao autor quando estas se referirem a este. Em relação aos demais autores as referências serão feitas normalmente.
} 
complementares. O regime de escoamento do rio, praticamente não sofre alteração no período das cheias.

Segundo Brighetti (2001) apud Santana (2008), essa técnica diminui a erosão causada pela lâmina d'água mínima e velocidade alta das águas (regime crítico), ao aumentar a profundidade e diminuir a largura, e pode evitar ou minimizar derrocamentos.

A escolha de qual braço ser fechado é orientada pelas circunstâncias locais como a topografia, a localização de comunidades e pontes, o valor do terreno ou a existência de pequenos terminais e demais acessos terrestres.

\subsubsection{Obras de Retificação do Leito}

Sob o enfoque estrito da navegação, os rios meandrantes representam um alongamento das vias navegáveis, aumento da sinuosidade do traçado ou uma caprichosa distribuição dos bancos de material particulado, dificultando e encarecendo o transporte. A intervenção direta ou indireta nesses rios exige o entendimento do meandro, de modo que a intervenção venha a provocar alterações benéficas no curso do rio (SILVA, 2004).

As obras de retificação do leito visam melhorar as condições de navegabilidade de um rio através do aumento do raio de curvatura e da redução da extensão navegável, diminuindo o caminho entre dois pontos. É uma técnica empregada em trechos sinuosos de rios que possuem raios de curvatura pequenos e oferecem riscos à navegação. Este tipo de obra regulariza o perfil transversal de um rio, em muitos casos, criando canais com seção uniforme. Algumas vezes são realizados somente serviços para aumento da largura das margens, ou seja, 0 alargamento das mesmas para facilitar a passagem das embarcações, principalmente nas curvas.

A retificação do leito tende a aumentar a declividade da linha d'água e a velocidade do escoamento, gerando um aumento da concentração e do transporte de sedimentos pelo curso d'água, bem como da erosão das margens deste.

Segundo Silva (2004), a retificação de meandros, só terá êxito a partir dos conhecimentos específicos dos meandros fluviais, tais como: origem, mecanismos de formação, localização e caracterização dos meandros. 
7.5.3. Contração Lateral do Leito e Limitação dos Leitos de Inundação

As obras de contração lateral do leito visam aumentar o nível d'água e consequentemente a profundidade do trecho navegável, através da construção de novas margens que reduzem a largura original do leito.

Para aplicação do método da contração do leito podem ser realizadas obras longitudinais ou transversais. As longitudinais são constituídas por diques dispostos paralelamente às margens, enquanto que as transversais são constituídas por espigões perpendiculares ou inclinados em relação às margens.

Silva (2004) refere-se à limitação dos leitos de inundação, que tem o objetivo de concentrar o escoamento num leito bem definido ou de proteger os terrenos ribeirinhos. Segundo o autor, nesse caso as obras são diques longitudinais, que podem ser construídos a seco, aproveitando o período de estiagem, localizados no leito menor. Em relação a esta técnica, o autor alerta para cuidados que devem ser tomados para a drenagem de área protegida, quando a mesma for utilizada para fins agrícolas, e para o aumento da capacidade erosiva das correntes provocado pela concentração das vazões, o que pode acarretar à erosão dos leitos.

\subsubsection{Regularização dos Leitos}

A regularização de um rio é obtida por obras construídas no leito para concentrar ou dirigir as correntes, especialmente nas estiagens, visando a obtenção de um leito estável, segundo um certo traçado, e um perfil transversal determinado, a fim de corrigir e regularizar as imperfeições naturais, obtendo-se as profundidades desejadas (SILVA, 2004).

Estas obras visam utilizar a energia das águas para fixar o traçado do leito, melhorar o escoamento e as condições de navegabilidade do rio, modificando para tanto: a largura, as curvaturas, a profundidade e a direção dos filetes de água utilizando-se diques, espigões e soleiras ou diques de fundo. As modificações de traçado obedecem à fórmula de Chézy e às Leis de Fargue e visam uma variação contínua das curvaturas e a formação de rampas e contra rampas no fundo, de maneira contínua. Outro princípio é o de "Girardon", que consiste em conservar os bancos, dando uma "boa passagem" entre eles (Del Grande, 1989 apud SILVA, 2004). 
O Método de Girardon, também conhecido como "Modelagem do Leito", procura empregar os princípios das Leis de Fargue, que são utilizados para realizar obras de melhoramento das condições de navegação de um rio, sem contrariar as leis naturais de formação deste.

A grande regra de Fargue era consultar a natureza, observando o modo pelo qual os fatos se sucediam, procurando reproduzir as condições favoráveis aos bons trechos navegáveis. As leis de Fargue possuem como princípio básico o fato de que o formato planialtimétrico de um curso d'água (traçado de suas margens em planta) influência nas profundidades do mesmo. Neste caso os métodos baseados nessas leis pretendem obter boas profundidades através de obras que impõem um bom traçado planialtimétrico do rio.

O método de Girardon, além de dar uma grande importância à continuidade do formato planialtimétrico, também trata de assegurar a continuidade nos perfis transversais e longitudinais do rio, trabalhando com os três planos simultaneamente, por isso também sendo conhecido como processo de "modelagem" do leito.

Este método consiste basicamente na transformação das chamadas "más passagens" em "boas passagens", por meio de obras fixas, como diques laterais, espigões mergulhantes e lages ou soleiras de fundo, que ao invés de evitarem a formação dos baixios, provocam seu aparecimento em pontos previamente determinados que não prejudicam a navegação.

As maiores profundidades em um leito sinuoso situam-se sempre ao longo das margens externas. A linha de talvegue cruza o rio próximo ao ponto de inflexão. Se este cruzamento é brusco, tem-se uma má passagem, se suave uma "boa passagem" (SILVA, 2004).

\subsubsection{Dragagem}

Entende-se por dragagem a retirada, transporte e disposição final de sedimentos do canal de navegação ou do leito dos rios. A dragagem é um método relativamente simples e direto para se melhorar um curso d'água para fins navegação e consiste na retirada de material sólido que é transportado por arraste, mais precisamente na retirada dos bancos ou baixios formados no leito do canal navegável. 
Utiliza-se a dragagem tanto na implantação como na manutenção de canais navegáveis. Esses conceitos de dragagem de implantação e dragagem de manutenção são utilizados principalmente para dragagem portuária. A dragagem de implantação, ou dragagem inicial, é aquela por meio da qual é formado o canal artificial com a retirada de material virgem. Já a dragagem de manutenção, consiste na retirada de material sedimentar depositado recentemente, com a finalidade de manter a profundidade do canal.

Torres (2000) apud Santana (2008) ainda apresenta um terceiro tipo de dragagem, que é a dragagem ambiental, em que sítios contaminados por outras atividades, tais como sedimentos orgânicos e inorgânicos oriundos de atividades diversas, como mineração, agricultura e industriais, são dragados e dispostos adequadamente.

A dragagem apresenta como uma de suas maiores desvantagens o fato de mudar a configuração do fundo do rio sem, ao mesmo tempo, mudar as forças que produziram tal configuração, que dependem da disposição geral do fluxo d'água e do transporte de matéria sólida. Isso significa dizer que a dragagem por si só, não elimina as más condições de navegabilidade de um curso d'água, pois não atua sobre as causas e sim sobre os efeitos (PRADO E COSTA, 1998).

$O$ perfil batimétrico de um rio de fundo móvel toma o aspecto de uma sucessão de longos trechos com boas profundidades, separados por curtos trechos de baixa profundidade, denominados de baixios, que limitam o calado das embarcações. Esses baixios podem se recompor em cada enchente, de modo que a dragagem pode ter que ser feita após cada ciclo de enchente.

Uma das soluções para este problema pode ser o estreitamento simultâneo do leito, o que irá aumentar a capacidade de erosão do curso d'água impedindo, dessa forma, novas formações dos baixios e provocando uma autodragagem. Neste caso os materiais trazidos pela correnteza estarão propensos a se depositar a jusante, numa região que não foi estreitada, e ali formar novos baixios.

$\mathrm{Na}$ dragagem deve-se sempre que possível buscar a consonância entre o alinhamento do canal dragado e a corrente, pois em caso contrário, as forças de sedimentação só tenderão a aumentar (PRADO E COSTA, 1998).

Os níveis de referência dos projetos de dragagem nos mares, em sua maioria, podem ser deterministicamente definidos, pois são fenômenos astronômicos, enquanto que nos rios, a formação das superfícies líquidas apresenta 
caráter probabilístico, em virtude de dependerem de fenômenos de natureza meteorológica. Assim devidos a estas incertezas e à aleatoriedade pluviométrica, as quantidades a serem dragadas variam de ano a ano nos rios, em função dos níveis d'água esperados (PRADO E COSTA, 1998).

O período de realização das dragagens para retirada dos baixios deve iniciarse após a passagem da enchente, ou seja, no início da descarga decrescente após o período de enchente. No Brasil, normalmente as dragagens fluviais ocorrem, quando necessárias, num período relativamente curto, de cerca de três meses, conforme exemplo da Figura 7.2.

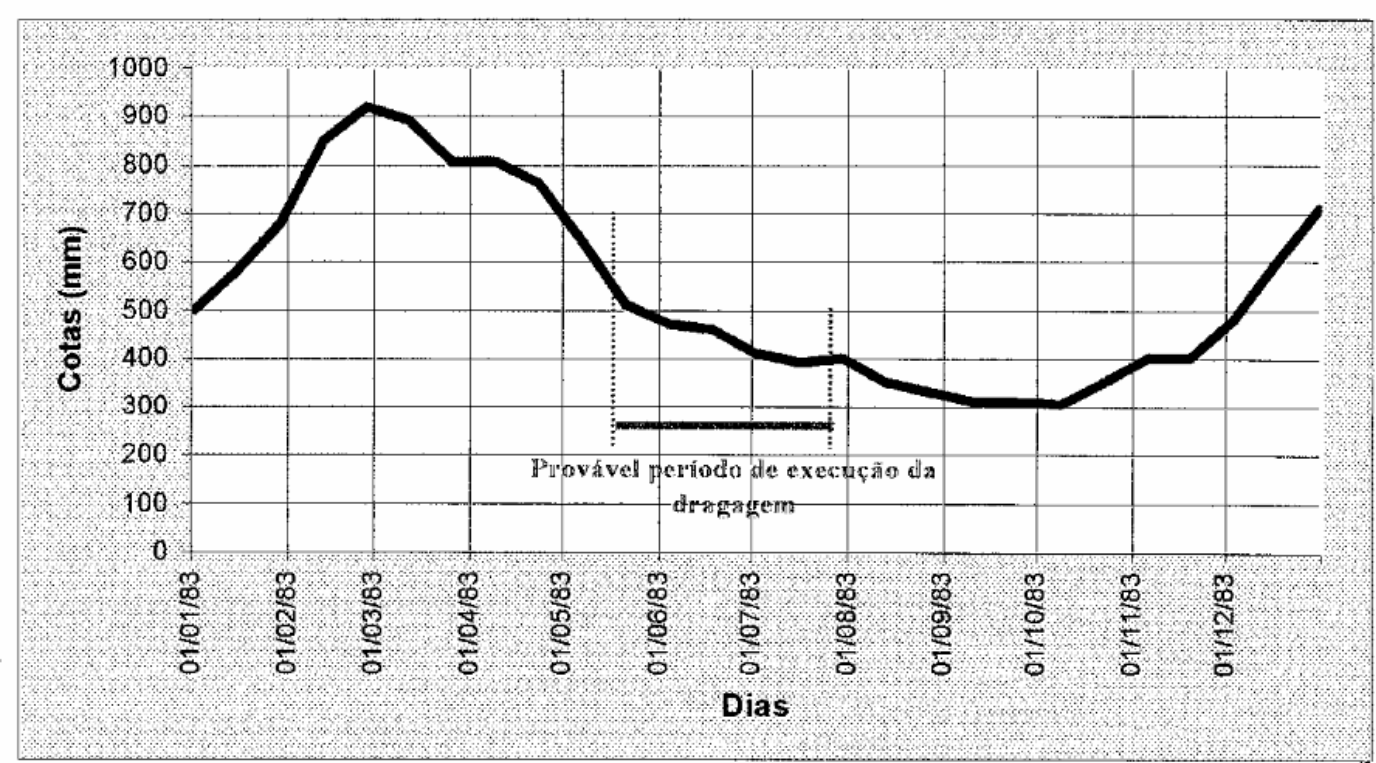

Figura 7.2 - Fluviograma do posto limnimétrico de São Félix do Araguaia, no Rio Araguaia, ano de 1983, apresentando o provável período de execução da dragagem.

Fonte: Prado e Costa (1998)

De acordo com Santana (2008), a operação de dragagem tem três instantes distintos, a saber, a retirada do material, o manejo (transporte) do material dragado e por fim o despejo (a disposição final) do material dragado.

O despejo do material dragado é um dos pontos principais a ser considerado, pois em função do local de deposição deste, podem ocorrer complicações futuras que tornarão a dragagem bastante cara, ineficiente e prejudicial ao meio ambiente.

Com relação aos métodos de dragagem, existem basicamente dois tipos principais: o de sucção hidráulica e o mecânico. 
Os tipos mais usuais de dragas são as de sucção e recalque. Esse tipo de draga hidráulica trabalha de uma forma geral recolhendo material do fundo através de tubulações de sucção, sendo a mistura descarregada através de bombeamento, em um batelão ou por uma tubulação até a área de despejo desejada. Essas dragas removem o substrato do fundo retirando inclusive os organismos bentônicos, invertebrados e peixes, porém são menos impactantes do que as dragas mecânicas, pois não provocam grandes alterações das propriedades físicas e químicas das águas. Algumas dragas de sucção podem possuir também desagregadores de material de fundo ("cutter suction dredge").

Existem também as dragas autotransportadoras de arrasto ("hopper dredge"), que são empregadas normalmente nos casos de não existirem áreas disponíveis para despejo. Essas dragas são geralmente de grande porte devido à existência de cisternas em seu interior para receber o material dragado que é lançado em alguma região possível de despejo. As dragas autotransportadoras são empregadas principalmente para trabalhos em regiões estuarinas e litorâneas.

Outro tipo de dragagem existente é a mecânica, que retira o material do fundo através de dispositivos mecânicos. As dragas mecânicas podem ser classificadas, de acordo com os tipos em: dragas de caçamba de mandíbulas ("clamshell'), escavadeira frontal ("dipper"), retroescavadeira ("hoe"), de pá-dearrasto ("drag-line") e de alcatruzes ("endless chain buckef") (OTTONI, 1986). A dragagem mecânica transfere uma grande quantidade de sedimentos para outra área, receptora, que poderá ser afetada e provocar alterações nas propriedades físicas e químicas de toda a coluna d'água e interferindo na ictiofauna e nas comunidades bentônicas. Normalmente provocam mais alterações ambientais que as de sucção. O Quadro 7.10 apresenta os principais tipos de dragas.

Quadro 7.10 - Principais tipos de dragas.

\begin{tabular}{|c|c|}
\hline Categoria & Tipo \\
\hline \multirow{3}{*}{ Mecânica } & Dragas de alcatruzes (bucket dredge) \\
\cline { 2 - 2 } & Dragas de caçambas (grab dredge) \\
\cline { 2 - 2 } & Dragas escavadeiras (dipper dredge) \\
\hline \multirow{3}{*}{ Hidráulica } & Dragas de sucção (suction dredge) \\
\cline { 2 - 2 } & Dragas de sucção com desagregadores (cutter suction dredge) \\
\cline { 2 - 2 } & Dragas autotransportadoras (trailing hopper dredge) \\
\hline
\end{tabular}

Fonte: ALAD/CBD (1972) apud Santana (2008) 
Para se determinar o tipo de draga a ser utilizado, devem ser analisados alguns aspectos como: profundidade da dragagem, quantidade e característica do material a ser removido, grau de poluição a ser gerado no ecossistema aquático, volume de trafego de embarcações na via e distância entre o local de despejo de material (OTTONI, 1986).

\subsubsection{Derrocamento}

Derrocamento é a retirada de rochas do canal, que podem dificultar a navegação e provocar acidentes. Assim, as obras de derrocamento são empregadas nos trechos de cursos d'água cujo leito é rochoso. Os métodos para derrocamento podem ser divididos em explosivos e não explosivos.

Os métodos não explosivos podem ser mecânicos, hidráulicos e eletromagnéticos e são aplicados para rochas com menor dureza e para remoção de camadas mais finas destas. Nesses métodos o desmonte da rocha pode ser realizado por percussão (marreta, soquete, aríete) ou por perfuração e percussão (martelete) (SILVA, 2004).

Os métodos explosivos consistem na detonação de rochas subaquáticas que geralmente apresentam alto custo (AHITAR, 1996). O sistema de perfuração e detonação geralmente é composto de uma perfuratriz que usa percussão e rotação para realizar os furos, para posterior carregamento das minas de acordo com um plano de fogo previamente estabelecido.

Os fragmentos de rocha derrocados são retirados normalmente por uma draga e transportados em chatas que descarregam o material pelo fundo, para locais a serem aterrados, ou em chatas de fundo fixo, de onde o mesmo é retirado para colocação em terra.

Segundo Silva (2004), o derrocamento geralmente tem como consequências o aumento da velocidade das águas e o rebaixamento do nível d'água a montante, resultando no desequilíbrio do rio, o que dá origem aos impactos ambientais, que deverão ser minimizados com a escolha adequada da técnica de execução, bem como da escolha correta do equipamento, além da necessidade da execução de obras complementares. 


\subsubsection{Canalização}

A canalização consiste na construção de represamentos e, consequentemente, em obras de transposição de desnível, como, por exemplo, as eclusas. Este método se baseia na construção de uma ou mais barragens transversais em diversos pontos de um rio de modo a aumentar a profundidade em cada trecho e permitir a navegação livre das embarcações nos estirões navegáveis formados pelo represamento das águas.

Esse tipo de obra provoca modificações significativas no perfil longitudinal original do rio, sendo que na estiagem, o novo perfil fica constituído por uma série de degraus, análogos aos de uma "escada", cuja transposição dos desníveis formados é realizada através de eclusas, no caso mais geral. Existem alguns outros métodos não convencionais para transposição de desníveis que são menos empregados como: eclusas de grandes quedas, elevadores, planos inclinados longitudinais e transversais, ascensores e rampas hidráulicas.

As barragens transversais utilizadas para "canalizar" um curso d'água, podem ser fixas ou moveis, sendo que as moveis não influenciam o nível do rio nas épocas de cheia, além de permitirem a passagem do material solido de uma forma eficiente (AHITAR, 1996).

\subsubsection{Construções de Canais Artificiais}

Entende-se por canais artificiais o ato de dirigir ou encaminhar o escoamento das águas, através de canos, valas ou canais fora do leito natural. Os canais artificiais podem ser criados para diversas finalidades. Os principais e mais executados são os canais laterais e os canais de ligação de bacias, também conhecidos como canais de "ponto de partilha".

Os canais laterais artificiais, também conhecidos como derivações laterais, são normalmente construídos para a transposição de trechos difíceis como corredeiras, regiões de grande declividade ou com raios de curvatura muito pequenos. O canal pode ser ou não eclusado dependendo da declividade média do braço artificial criado. Caso o comprimento a ele dado for suficiente para fazer com que a declividade média não seja muito forte, não haverá necessidade de eclusas. Porém, nas regiões rochosas, esta solução de uma derivação artificial bastante 
longa, a fim de não necessitar de eclusas, levaria as obras a uma despesa inviável. A derivação navegável para transposição de uma corredeira pode necessitar então, de uma ou mais eclusas.

Os "canais de partilha" ou "canais de ponto de partilha" são interligações de dois rios, que podem ser ou não de uma mesma bacia hidrográfica. Este tipo de canal é bastante empregado em muitos rios da Europa.

De uma maneira geral, alguns cuidados devem ser tomados na execução dos canais artificiais, como a proteção das margens dos mesmos, principalmente devido ao embate das ondas provocadas pela passagem das embarcações.

Outro cuidado fundamental que se deve ter na interligação de bacias distintas, é a existência de comunidades aquáticas diferentes e antagônicas, que pode conduzir a graves problemas como desequilíbrios e desaparecimentos de espécies originais da fauna e flora aquáticas.

\subsubsection{Serviços de Sinalização e Balizamento}

Assim como uma estrada rodoviária, o rio também precisa de sinalização, que para hidrovias se divide em sinalização e balizamento. Os serviços de sinalização e de balizamento são fundamentais para a segurança do trafego das embarcações na hidrovia.

De acordo com a Norma da Autoridade Marítima para Auxílio à Navegação, da Diretoria de Hidrografia e Navegação da Marinha do Brasil - NORMAM-17/DHN, a sinalização náutica é o conjunto de sinais náuticos visuais, fixos ou flutuantes, externos à embarcação, especificamente estabelecidos com o propósito de garantir uma navegação segura e econômica nas vias navegáveis.

O conceito de auxílio à navegação, mais abrangente, engloba os sinais náuticos. Os termos "sinal náutico" e "sinalização náutica" são de uso consagrado no Brasil para indicar os auxílios visuais à navegação externos à embarcação, providos por uma autoridade responsável pela sinalização náutica de uma determinada região, área ou porto.

Por sua vez, o balizamento é o conjunto de balizas, boias, barcas-farois, objetos naturais ou artificiais, padronizados ou não, e de farois e faroletes que concorrem para a garantia da segurança da navegação em uma região ou área 
perfeitamente definida, como canais de acesso e bacias de evolução de portos e terminais, marinas e hidrovias.

\subsubsection{Desobstrução e Limpeza do leito}

Consistem na retirada de obstáculos estranhos ao leito como vegetais ou embarcações encalhadas que dificultam o escoamento ou desviam os filetes líquidos.

Este serviço, segundo a Marinha do Brasil (2006) apud Santana (2008), é um trabalho preliminar de grande utilidade, pois estes obstáculos constituem sérios perigos para as embarcações. Salienta ainda o autor, que em algumas hidrovias, é necessário realizar periodicamente a remoção de balseiros, camalotes, aguapés e outras plantas aquáticas que descem os rios, concentrando-se em determinados locais e formando grandes ilhas flutuantes, que chegam a obstruir completamente a via navegável.

\subsubsection{Manutenção}

A manutenção tem por objetivo manter as características físicas e operacionais das vias navegáveis interiores. Atualmente, a execução das atividades de manutenção está a cargo das oito administrações hidroviárias.

As principais atividades de manutenção de hidrovias são: batimetria, medição do nível das águas, confecção e atualização de cartas, destocamento, dragagem, sinalização, monitoramento ambiental e manutenção de equipamentos e de eclusas. Para a realização das atividades de manutenção, devem ser identificados os pontos críticos da hidrovia, para que sejam sinalizados por meio de placas ou boias, bem como dragados antes dos períodos de seca, a fim de não haver o impedimento ou subutilização da via navegável (BRASIL, 2006b).

O Tribunal de Contas da União aponta como consequência dos serviços insuficientes de manutenção o aumento do risco da navegação, diminuição da navegação ou interrupção de trechos e necessidade de navegação com calado menor do que o pretendido pelas empresas de navegação, por falta ou atraso das dragagens e desassoreamentos (BRASIL, 2006b). 
Brasil (2007a) elencou as principais atividades de manutenção de hidrovias, que são replicadas a seguir:

"batimetria: medição ordenada e sistematizada das profundidades de determinada área, visando à definição do perfil do fundo, ao detalhamento do leito do canal navegável e à identificação e localização de perigos à navegação, tais como pedrais ou bancos de areia;

medição do nível das águas: as medições são feitas em estações hidrométricas, que têm por elemento principal as linhas de réguas limnimétricas ou medidores eletrônicos da altura da água. As informações coletadas e registradas nas estações hidrométricas contribuem decisivamente para a segurança da navegação;

confecção e atualização de cartas: serviço especializado de cartografia e hidrografia que permite a geração da carta náutica e de outras cartas auxiliares e navegação;

confecção e atualização de cartas eletrônicas: possibilita o posicionamento instantâneo da embarcação, eliminando ou reduzindo significativamente os erros de observação e plotagem dos navegadores;

derrocamento: retirada de pedras ou lajes que oferecem perigo à navegação, normalmente, por explosão;

desobstrução do canal: retirada de objetos que impedem ou tornam perigoso o tráfego de embarcações no canal navegável da hidrovia;

destocamento: remoção de tocos ou cepos de árvores do leito do rio;

dragagem: retirada de material do fundo do leito das águas, de forma a garantir profundidades mínimas para o tráfego de embarcações de maior calado;

sinalização de margem: colocação de sinais nas margens da hidrovia para indicar rumos, perigos, caminhos ao navegante;

sinalização flutuante: conjunto de sinais flutuantes que compõem a sinalização da hidrovia, junto com a sinalização de margem. O conjunto de elementos de sinalização (de margem ou flutuante) é chamado balizamento;

monitoramento ambiental: as administrações hidroviárias devem realizar atividades de monitoramento ambiental para atender às exigências contidas nas licenças ambientais (condicionantes);

manutenção de equipamentos: algumas administrações hidroviárias dispõem de equipamentos específicos para o desempenho de suas atividades, tais como: dragas, embarcações destocadoras, rebocadores, embarcações para pesquisa e embarcações de transporte de equipes de fiscalização;

manutenção de eclusas: algumas administrações hidroviárias têm como uma de suas atribuições operar e manter em funcionamento as eclusas nos rios sob sua administração." (BRASIL, 2007a)

No entanto, com base nos conceitos apresentados nessa dissertação, o derrocamento e as dragagens, quando utilizadas para ampliação de capacidade, são consideradas atividades de melhoramento, apesar de elencado por Brasil (2007a) como atividade de manutenção. 


\section{QUESTÃO AMBIENTAL}

A construção, ampliação e manutenção de sistemas de transportes são indispensáveis para o desenvolvimento de importantes atividades, como o transporte de pessoas, matérias primas e produtos, além de possibilitar o desenvolvimento econômico e social de uma região.

Vital para o desenvolvimento econômico e social, o transporte também gera consequências indesejáveis em escala local, regional e global. De acordo com Schäfer (2012), impactos locais incluem acidentes e congestionamentos, ambos causando graves prejuízos econômicos; um impacto chave de escala regional é a poluição do ar urbana, e; o impacto global dos transportes mais discutido atualmente é afeto às mudanças climáticas.

A relação entre transportes e meio ambiente é múltipla e envolve: a infraestrutura de transportes, os veículos e os fatores associados à acessibilidade e mobilidade; os usuários do sistema de transportes e as populações afetadas, positiva e negativamente, pela implantação e operação da infraestrutura e dos serviços de transportes, e; as características e condições do meio ambiente sob influência direta e indireta dos transportes (BRASIL, 2003a).

Brasil (2003a) ressalta que as discussões de paradigmas de desenvolvimento, de integração regional e de ocupação e uso do solo devem ser realizadas previamente às decisões sobre investimentos setoriais, com a participação de todos os agentes envolvidos. Nesse contexto, os transportes constituem meio de viabilização da ocupação do território, do deslocamento de bens e pessoas e têm, portanto, objetivos diretamente ligados às políticas de desenvolvimento.

A Política Europeia de Transportes foca atualmente no conceito de mobilidade sustentável (PORTUGAL, 2009). A mobilidade das pessoas e mercadorias é encarada como uma componente essencial da competitividade das indústrias e serviços, sendo também um direito essencial dos cidadãos. Ela é a espinha dorsal da economia, estabelecendo os elos entre as várias etapas das cadeias de produção e possibilitando que os prestadores de serviços sirvam os seus clientes, além de ser também uma importante fonte de emprego (COM, 2008).

Mas a mobilidade também tem custos sociais. As emissões dos meios de transporte são prejudiciais para a saúde, afetam negativamente a qualidade do meio 
ambiente local e contribuem de forma significativa e crescente para as alterações climáticas. Ademais, o ruído e os engarrafamentos são um transtorno diário para muitos cidadãos e os acidentes matam milhares todos os anos.

Para muitos, os impactos de maior preocupação dos sistemas de transporte são os efeitos adversos das emissões atmosféricas associadas ao consumo de combustível, incluindo as emissões de gases de efeito estufa. A eficiência energética é uma consideração importante na busca da combinação mais benéfica de modos de transporte, incluindo os impactos atmosféricos (USACE, 2012).

Cabe ainda citar outros impactos da implantação de sistemas de transportes. Em relação à fauna e à flora, talvez mais prejudicial do que os impactos diretos são os impactos gerados pela fragmentação do habitat, que ocorre mais especificamente em transportes terrestres, com impactos mais evidentes no transporte rodoviário.

Os impactos ambientais potenciais e as necessidades de mitigação são aspectos importantes do planejamento, conforme ressaltado em estudo realizado para modernização de hidrovias e portos americanos (USACE, 2012). Entretanto, o referido estudo reconhece que apesar dos custos de mitigação poderem ser substanciais, receberam menos atenção do que deveriam. No Porto de Savannah, no Estado de Geórgia - Estados Unidos, por exemplo, os custos de mitigação são de cerca de $45 \%$ do custo total estimado de expansão do porto, segundo o documento.

De acordo com o relatório, normas ambientais e exigências de licenciamento tornaram-se mais rigorosas, assim como seus benefícios tornaram-se mais claros. USACE (2012) alerta ainda que a ênfase na efetiva mitigação de impacto ambiental deverá continuar, ou aumentar, e deve ser uma consideração essencial na determinação dos custos e os benefícios líquidos de um projeto.

Nesse contexto, surgem diversas metodologias e propostas para avaliar e melhorar a qualidade ambiental dos projetos de transportes. A European Commission (2005) ilustra a aplicação da metodologia DPSIR para o setor de transportes. O DPSIR é uma estrutura causal para descrever as interações entre a sociedade e o meio ambiente, que tem sido adotado pela Agência Europeia do Ambiente. É uma extensão do modelo pressão-estado-resposta desenvolvida pela OCDE, cujos componentes são: Driving forces (Forças motrizes), Pressures (Pressões), States (Estados), Impacts (Impactos) e Responses (Respostas). 
No Reino Unido foi desenvolvida uma abordagem para melhorar a consistência e transparência na tomada de decisões de transportes denominada New Aproach to Appraisal - NATA (UNITED KINGDOM, 2004). No âmbito do NATA, os impactos de projetos de transporte são classificados em termos de cinco critérios de alto nível (economia, segurança, meio ambiente, acessibilidade e integração), o que reflete os objetivos do Governo para o transporte. Cada um desses critérios é dividido em um número de subcritérios. É contra cada um desses subcritérios que os impactos de uma proposta são avaliados. A metodologia leva em conta os seguintes subcritérios para o critério meio ambiente: poluição sonora, qualidade do ar local, gases de efeito estufa, paisagem, paisagem urbana, patrimônio histórico, biodiversidade, ambiente aquático, aptidão física, ambiente da viagem.

Os impactos ambientais associados aos sistemas de transportes e à sua utilização traduzem-se em importantes custos para a sociedade, como por exemplo: congestionamento, danos na saúde associados ao ruído e à poluição atmosférica ou custos associados às alterações climáticas. No entanto, esses custos não são, de um modo geral, suportados diretamente pelos utilizadores dos sistemas de transportes, constituindo, portanto, externalidades. Nesse contexto, a Comissão Europeia tem chamado a atenção para a necessidade de refletir todos os custos sociais nos sistemas de tarifação dos transportes (internalização) como forma de influenciar as escolhas dos agentes econômicos e dos cidadãos no sentido de privilegiarem meios de transporte mais "ecológicos" (PORTUGAL, 2009).

\subsection{Impactos Ambientais dos Sistemas de Transportes}

A Resolução CONAMA nº 01, de 23 de janeiro de 1986, é a primeira norma brasileira a definir impacto ambiental. De acordo com 0 artigo $1^{\circ}$ da referida resolução, impacto ambiental é qualquer alteração das propriedades físicas, químicas e biológicas do meio ambiente, causada por qualquer forma de matéria ou energia, resultantes das atividades humanas que, direta ou indiretamente afetam: a saúde, a segurança e o bem estar da população; as atividades sociais e econômicas; a biota; as condições estéticas e sanitárias do meio ambiente; a qualidade dos recursos ambientais.

O transporte, além de gerar aumento da competitividade, desenvolvimento da economia nacional e assegurar a mobilidade e acessibilidade a pessoas e bens 
pode causar diversos outros efeitos positivos e negativos no meio em que se insere. Por isso, os seus impactos devem ser bem avaliados. Os principais impactos dos sistemas de transportes estão relacionados à biodiversidade, qualidade do ar e ruídos, acidentes, dinâmica territorial e qualidade dos recursos hídricos.

Com relação à biodiversidade pode ocorrer a fragmentação de habitats, 0 efeito barreira, as interferências em áreas ambiental e socialmente sensíveis e a invasão de espécies exóticas pelos meios de transportes. Quanto à qualidade do ar, verificam-se os impactos locais e globais das emissões atmosféricas relacionados ao consumo de combustíveis não renováveis. Observa-se ainda a exposição da população a níveis de ruídos elevados, congestionamentos e acidentes. Os transportes podem apresentar ainda efeitos sobre a qualidade e disponibilidade hídricas que são afetados pelos projetos de drenagem, acidentes e processos erosivos ao longo das vias. Por fim, o sistema de transportes se relaciona intrinsecamente com a dinâmica urbana e territorial. Nessa questão, se pode identificar efeitos na ocupação urbana, especulação imobiliária, assimetrias fundiárias, criação de postos de trabalho, aumento do potencial econômico e aumento de fluxo de pessoas.

Em relação aos impactos relacionados aos sistemas de transportes, Schäfer (2012) elenca como tópicos principais: consumo energético, emissões atmosféricas, uso da terra, impactos no meio ambiente e desenvolvimento regional. $O$ autor elenca ainda questões globais (mudanças climáticas e poluição do ar), recursos naturais (paisagem, biodiversidade e recursos hídricos) e assuntos comunitários (poluição sonora e qualidade do ar).

De acordo com Carvalho (2008), as alternativas estudadas para a satisfação das necessidades de transporte podem ocasionar efeitos ambientais de magnitudes variáveis, que não podem ser desconsiderados. Poluição do ar, ruídos, alterações sobre o solo e subsolo, alterações sobre as águas superficiais, impactos sobre o meio biótico, segregação de comunidades e alterações climáticas são alguns dos possíveis efeitos advindos do desenvolvimento de projetos de transporte elencados pelo autor. De forma semelhante, Santana (2008) apresenta a seguinte avaliação sobre os impactos:

Há, classicamente, alguns principais impactos decorrentes dos aspectos ambientais da implantação e operação dos sistemas de transportes, em geral, tais aspectos são: poluição do ar; poluição do solo; poluição sonora e 
vibrações; poluição das águas superficiais e subterrâneas e alterações no uso do solo.

Veículos automotores assumem a responsabilidade de parte expressiva da poluição do ar. Os impactos provenientes de ruídos e vibrações são mais sentidos em áreas urbanas com grande tráfego de veículos e com existência de terminais próximos à população. As alterações ocorridas nas águas superficiais e subterrâneas podem acontecer de várias formas por ocasião da implantação e operação de sistemas de transportes, tais como o desvio temporário ou permanente dos cursos d'água, a impermeabilização de superfícies, os movimentos de terra, arraste de partículas poluentes e os acidentes com cargas tóxicas. Todas as atividades que alterem as características originais do ar, das águas e do solo, afetam diretamente a fauna e a flora, por isso causam impactos ambientais. A implantação de novas vias ou terminais de transporte causam alterações na paisagem, desapropriações, deslocamentos de atividades, mudanças socioculturais na população local e segregação de comunidades vizinhas. A atratividade exercida pela implantação de sistemas de transportes sobre o meio socioeconômico induz alterações no uso do solo devido à geração de movimentos migratórios e ao aumento do adensamento populacional. (SANTANA, 2008)

\subsection{Impactos Ambientais dos Projetos Hidroviários}

Os impactos do transporte hidroviário interior podem ser divididos em impactos da execução de obras e atividades, impactos gerados pelas embarcações e impactos resultantes do desenvolvimento regional provocado pela melhoria do transporte de cargas e ou de passageiros (PADOVEZI, 2003; SANTANA e TACHIBANA, 2004; SANTANA, 2008).

A Conferência Europeia dos Ministros dos Transportes (European Conference of Ministers of Transport - ECMT) elaborou relatório (ECMT, 2006) que aborda os procedimentos de avaliação ambiental para transporte hidroviário interior na Europa, considerando "EIA Directive", "EU Birds and Habitats Directives", "Water framework Directive", "UNECE Conventions" e outros instrumentos normativos europeus. Além disso, apresenta práticas e experiências em países selecionados, como França, Alemanha, Áustria, Romênia e Ucrânia, concluindo com as lições aprendidas.

Também sobre o transporte hidroviário interior, a Associação Mundial para a Infraestrutura de Transporte Aquaviário - PIANC elaborou relatório (PIANC, 2003) que descreve importantes funções do rio e fornece orientações sobre aspectos práticos da administração fluvial com ênfase na gestão sustentável da infraestrutura da navegação, contemplando tópicos como: navegação, descrição do rio, definição de termos, funções do rio, usos primário, secundário e adicional, hidrologia, 
morfologia do rio, ecologia do rio, infraestrutura do rio, planejamento de uso da terra, recreação, pesca, paisagem, conservação da natureza, restauração e dinâmica temporal e espacial. O relatório faz uma relação entre os usos e funções fluviais, apresenta tabela de impactos e faz propostas de planejamento para projetos hidroviários.

Alguns autores classificam os impactos em sociais, ou socioeconômicos, e ambientais, ou sobre o meio físico e biótico. Esse é o caso apresentado na estrutura hierárquica utilizada por Carvalho (2008) para avaliação de projetos de transporte hidroviário interior em que os "Efeitos Ambientais" são divididos em "Impactos Sociais" e "Impactos sobre a Natureza". Entre impactos sociais o autor cita: conflitos com comunidades indígenas, danos ao patrimônio histórico e arqueológico, demanda descontrolada por serviços, choque cultural entre população local e emigrada e incremento de atividades marginalizadas. Como impactos sobre a natureza são elencados: poluição do ar, efeitos sobre a fauna e a flora, qualidade dos recursos hídricos e modificação da paisagem.

Segundo Santana e Tachibana (2004), a área de influência direta da implantação das obras necessárias é o próprio leito do rio, que é o local onde se efetuam as principais intervenções necessárias e, de forma pontual, uma pequena faixa da margem é utilizada. Entre as obras e atividades para o transporte hidroviário interior, incluem-se todas necessárias à implantação de canais e às intervenções, sejam de implantação, melhoramento e manutenção, sendo as principais o derrocamento e as dragagens.

Outros impactos relacionados ao transporte hidroviário são gerados pela operação das embarcações. Dentre esses cabe citar: risco de acidentes, em especial quando envolvidas cargas perigosas; emissões geradas pela queima de combustíveis; derramamentos, ocorridos no transporte e principalmente no processo de carga e descarga; despejos gerais gerados na embarcação; efeitos da propulsão e deslocamento das naves, como ondas e revolvimento de fundo; colisões com outras embarcações ou elementos da via como pontes, eclusas e margens; bem como a introdução involuntária de espécies exóticas nos cursos d'água e as ameaças de embarcações abandonadas ou fora de uso. Os impactos relacionados às embarcações são profundamente estudados por Padovezi (2003).

Os impactos potenciais relacionados ao transporte hidroviário interior de cargas, como acidentes, merecem grande atenção, pois o mesmo utiliza 
diretamente os cursos d'água. Se por um lado é benéfico em termos ambientais, por outro, é exatamente pelo fato da via ser um meio natural que as consequências dos acidentes geram mais preocupações. Dessa forma, acidentes na navegação é um tema que carece de muito cuidado.

As alterações no território e o desenvolvimento regional, catalisados pela utilização da via, são constantemente citados como alguns dos principais questionamentos relacionados aos empreendimentos de transportes. Esses impactos, positivos e negativos, em geral, se manifestam no longo prazo pela melhoria de acesso que pode induzir mudanças na ocupação do território. Observase, rotineiramente, uma confusão na interpretação entre os impactos causados pelas intervenções nas vias fluviais, com outros, relacionados ao transporte ou associados à operação de portos e incrementos na economia.

Uma hidrovia implica uma série de impactos positivos e negativos sobre o meio ambiente da sua área de influência. A despeito de estarem associados ao processo de crescimento e desenvolvimento econômicos, os impactos positivos representam benefícios e os negativos custos que deveriam ser considerados na análise de viabilidade econômica da implantação e operação hidroviária (ALMEIDA, 2004).

Conforme já apresentado anteriormente, os impactos devido ao transporte de cargas e os efeitos na ocupação do território são inerentes a todos os modos de transportes. Nessa conjuntura, o hidroviário apresenta impactos referentes à ocupação territorial menores do que outros modos.

Em relação ao desenvolvimento e ocupação do território, deve-se considerar que o sistema de transportes é parte de uma política de desenvolvimento maior, não um fim em si. Portanto, o sistema de transportes tem como objetivo atender ao desenvolvimento já iniciado ou proporcionar o desenvolvimento planejado. Não seria adequado, dessa forma, que o desenvolvimento de uma região fosse analisado em um projeto de um empreendimento de transportes. Entende-se que o correto seria que o empreendimento atendesse às necessidades e planejamento já estabelecidos para o território.

Por outro lado, cabe citar também alguns impactos de outras atividades sobre as vias navegáveis. Um dos mais importantes degradadores dos cursos d'água é o inadequado uso e ocupação do solo na bacia hidrográfica. Atividades terrestres funcionam como fonte primária de sedimento que é transportado para dentro do 
corpo d'água pelo escoamento superficial. Atividades industriais e urbanas são geradoras de poluentes contaminados que também alcançam os cursos de água, ocasionando problemas ambientais, bem como dificuldades para as intervenções na hidrovia, como as dragagens de sedimentos contaminados, que necessitam de procedimentos técnicos muito mais custosos.

Para a manutenção da hidrovia com o menor número de intervenções é importante a conservação da bacia hidrográfica. Padovezi (2003) afirma que a “preservação ambiental interessa diretamente à navegação". Segundo o autor, há uma necessidade de uma visão sistêmica de todo o entorno de um determinado rio, já que, por exemplo, a navegação é prejudicada por assoreamentos resultantes de má utilização do solo ribeirinho.

De acordo com CEBRAC (1994), em uma análise focada no rio Paraguai, a erosão do solo utilizado na produção de soja e milho está assoreando os rios do Pantanal brasileiro, conforme já pode ser observado no rio Taquari - MS, provocando a necessidade de medidas mitigadoras para os efeitos danosos, inclusive, já se podendo prever um grande volume de dragagem. Essa relação uso do solo, assoreamento de cursos d'água e dragagem pode ser aplicada a outros casos. Esse processo é apresentado por Lima e Oliveira (2007), da seguinte forma:

\footnotetext{
Com a remoção da vegetação, a impermeabilização e a construção de infraestrutura hídrica, o solo fica desprotegido e suas características físicas, principalmente a estrutura, vão-se degradando e tornando mais difícil a infiltração isso tudo provoca acréscimo no escoamento superficial. A erosão aumenta no período chuvoso, aumentando também a produção de sedimentos. Espera-se então que na estiagem a lâmina d'água seja menor, assim como a capacidade do rio de abrir canais nos sedimentos depositados levando ao consequente aumento do volume de dragagem para se manter a profundidade mínima da hidrovia, o que de fato ocorreu no período estudado. (LIMA E OLIVEIRA, 2007)
}

\subsection{Impactos da Execução de AEH}

Diversos impactos ambientais e socioeconômicos podem ser causados pela realização de obras e atividades nas hidrovias, que podem ser, entre outras, dragagens, derrocamentos, sinalização, balizamentos, cortes de meandros, implantação de canais laterais e espigões ou ainda a construção de barragens. Vários autores listaram os impactos dos projetos hidroviários (FILLIPO, 1999; SILVA, 2004; DINIZ, 2007 e SANTANA, 2008). 
As obras e serviços executados nos cursos d'água, por um lado, concorrem para o aumento da segurança do tráfego hidroviário, promovendo a navegabilidade, o que constitui um impacto ambiental positivo, por outro, podem desestabilizar o equilíbrio natural do mesmo e provocar alguns impactos ambientais negativos (DINIZ, 2007). Conforme destacado por Padovezi (2003), na conjuntura atual, em que a questão ambiental está sempre presente, as hidrovias cada vez menos terão obras de grande porte para eliminação das restrições à navegação que possam existir.

Segundo Filippo (1999), grande parte dos impactos negativos ocorre nos meios físico e biótico, principalmente nos componentes ambientais água, solo, vegetação, fauna e flora aquática, enquanto o meio socioeconômico, como comunidades ribeirinhas, sofre impactos indiretos e muitas vezes diretos, decorrentes dos impactos nos meios físico e biótico, como, por exemplo, devidos à deterioração da qualidade das águas para consumo.

Para Diniz (2007), os impactos ambientais decorrentes de obras fluviais se manifestam direta e principalmente no meio físico, isto é, solo, água e ar e a partir deles são originados impactos indiretos nos meios biótico e antrópico. A probabilidade de ocorrência e a magnitude dos impactos associados às obras dependem das suas características, modo de execução, métodos construtivos e condições locais.

De acordo com USACE (1981), os principais impactos associados às hidrovias são efeitos relacionados à construção de barragens e fenômenos relacionados ao represamento, tais como alocação do fluxo e alteração do ambiente aquático, dragagem de manutenção, descarte de material dragado além de impactos gerais da navegação, como os derramamentos.

É necessário diferenciar os impactos da infraestrutura de transportes em rios de fluxo livre e em rios com barramentos. No Brasil, não é muito comum a utilização de barramentos para fins de navegação, ao contrário do que ocorre frequentemente na Europa e nos Estados Unidos. Nesse sentido, Santana (2008) apresenta a seguinte análise.

Implantação de uma hidrovia envolve diferentes tipos de impactos ambientais, a começar pelo tipo da via (rio) em que o sistema é implantado. Em uma hidrovia de fluxo livre é diferente de outra, onde o fluxo é confinado. CAMARGO JÚNIOR (2000) diz que onde o fluxo é livre, as obras hidroviárias contribuem para desequilíbrio fluvial, traduzido no aumento das taxas de assoreamento em trechos significativos do rio, como 
exemplos, as hidrovias Paraguai-Paraná, Tocantins-Araguaia e Madeira. Nestes casos, o aporte de sedimentos é proveniente da erosão gerada pela remoção da cobertura vegetal e pela movimentação de terra aleatória nas suas margens em que se pretende implantar as obras. Em hidrovias de fluxo confinado, como a Hidrovia Tietê-Paraná, a construção de barragens e eclusas promove alterações na dinâmica das vertentes marginais do lago formado, recuando-as e causando a incisão dos rios, com a inexorável intensificação de processos erosivos até que a dinâmica superficial reencontre seu ponto de equilíbrio. Haverá sempre controvérsias em ambos os casos, haverá sempre correntes contrárias em debates sobre 0 assoreamento dos rios, mas não se pode afirmar que é a introdução do transporte comercial que venha contribuir, diretamente, para isso, quando há na bacia hidrográfica, outros fatores contribuintes como a mineração, agricultura e outras atividades. Tudo isso, na verdade é a disputa e a partilha das correntes pelo difícil consenso no uso múltiplos das águas. (SANTANA, 2008)

Ressalta-se, conforme citado pelo autor, que há vários fatores que contribuem para o assoreamento e contaminação dos corpos d'água, como atividades industriais e outros relacionados ao uso e à ocupação do solo, abordados na seção anterior. Reforça-se, assim, o princípio da necessidade de controle das fontes de poluição, pontuais e difusas, que traria consequências benéficas para 0 meio ambiente e para a navegação.

\subsubsection{Implantação de Canais de Navegação}

A implantação de canais de navegação tem o objetivo criar canais onde não há curso d'água preexistente ou os cursos d'água existentes não possibilitam nenhum tipo de navegação, com os impactos de uma implantação se assemelhando ao primeiro caso. A implantação de canais gera impactos, principalmente, na execução das obras de implantação e os resultantes do desenvolvimento regional provocado pelo desenvolvimento provocado pela melhoria no acesso de cargas e de passageiros.

Os impactos relacionados à execução das obras de implantação, em geral, se assemelham com impactos da implantação dos demais empreendimentos de transportes, como rodovias e ferrovias. Destacam-se os impactos sobre os meios físicos e bióticos originados pelas atividades de movimentação de terra, obras de terraplenagem, desmatamento, movimentação de máquinas e os originados pelas atividades inerentes a construção, como o canteiro de obras, bem como os impactos no meio socioeconômico gerados pela migração temporária para as obras e a influência dessas sobre as atividades locais. Cabe mencionar, além desses, os 
possíveis impactos nos recursos hídricos e na biodiversidade ocasionados pela transposição de bacias e a interligação de rios.

\subsubsection{Intervenções}

As intervenções são obras ou serviços de engenharia necessários a incrementar ou auferir condições de navegabilidade em um curso d'água. As intervenções, dependendo do objetivo e da situação local, podem ser de implantação, melhoramento e manutenção. As principais intervenções realizadas no País, e que serão apresentas nos itens seguintes, são as dragagens, derrocamentos e construção de barragens. Além disso, serviços rotineiros são os de sinalização e balizamento, que geram impacto positivo no ordenamento e na segurança da navegação e que trazem pequenos impactos ao meio ambiente.

\subsubsection{Dragagem}

As principais intervenções realizadas no Brasil, tanto para tornar um trecho navegável como para manter a navegabilidade com segurança são as dragagens e os derrocamentos.

A dragagem consiste na retirada de material sólido do canal de navegação. $\mathrm{O}$ procedimento inclui ainda o transporte e a disposição do material dragado. No transporte hidroviário interior, a dragagem pode ser realizada com diversos objetivos, como implantação, melhoramento e manutenção, mas é nesse último que se destaca, pois é a principal atividade de manutenção do canal de navegação.

As dragagens de manutenção, realizadas periodicamente, são na realidade uma atividade similar à própria dinâmica fluvial dos rios, ou seja, o transporte natural das areias do fundo, variável com as direções das correntes, sólidos em suspensão e os níveis de água, é antecipado pelas dragagens, configurando, na maioria dos casos, obras de pequeno porte, concentradas ou limitadas em trechos de pequena extensão das calhas fluviais, conhecidos como trechos críticos, ou passagens difíceis (BRASIL, 2005). Os serviços de dragagem fluvial para fins de manutenção podem ocorrer quase todos os anos e devem ser executados em períodos relativamente curtos de tempo, pois são dependentes do ciclo hidrológico. 
Em uma simples explicação, os rios erodem as fossas e sedimentam os baixios nas cheias, e erodem estes e sedimentam aquelas nas vazantes, no seu contínuo processo de transporte de sólidos por arraste a jusante. Depreende-se que os sedimentos são inexoravelmente transportados pelos rios. Quando disposto o material dragado no próprio leito, a dragagem atua como um acelerador do processo de transporte de sedimentos.

O impacto da dragagem e disposição do material dragado na qualidade da água é geralmente de curta duração. As principais questões ambientais levantadas para as atividades incluem os aumentos temporários de sedimentos em suspensão, o aumento da turbidez, diminuição do oxigênio dissolvido e impactos localizados no habitat bentônico (USACE, 1981).

Em rios com problemas de poluição, as dragagens podem representar problemas maiores, pois pode aumentar a carga contaminante das águas do rio, além do problema do destino final do material dragado (BRASIL, 2005). Nesses casos, especialmente a disposição desse material requer que sejam tomados cuidados especiais.

Os impactos sobre o habitat aquático envolvem principalmente rompimento de substrato de fundo, destruindo, assim, certos organismos bentônicos; os efeitos negativos do aumento da turbidez e sedimentos em suspensão nos peixes; a redução geral na disponibilidade de oxigênio dissolvido e o enterro de organismos sésseis ou lentos por operações de descarte. Pode-se notar, no entanto, que, em muitos casos, estes efeitos são temporários e localizados e a área de disposição ou de dragagem é capaz de recuperar e restabelecer-se dentro de um período razoável de tempo. Contudo, se ocorrer uma grande ou recorrente ruptura, a reversão das condições originais do substrato pode ser impossibilitada (USACE, 1981).

Em geral, a dragagem reduz temporariamente a abundância de organismos, exceto em ambientes altamente alterados (USACE, 2012). Essa atividade pode ocasionar a substituição de unidades de maior diversidade por outras de menor diversidade além da destruição de habitats da fauna bentônica (SILVA, 2004).

Segundo Huszar et al. (1999), pode-se esperar impactos na fauna localizada nas proximidades das obras de dragagem, especialmente se os distúrbios acontecerem anualmente no período de reprodução ou a área for potencial para reprodução, já que os habitat de reprodução são essenciais para a maioria das espécies. O citado relatório, que discute a Hidrovia Paraguai-Paraná, aponta ainda 
que os organismos aquáticos seriam afetados devido: à remoção, à eliminação e ao transporte dos sedimentos decorrentes das dragagens; ao aumento da turvação das águas resultante das obras de dragagem e da intensificação da navegação; às mudanças hidrológicas; ao perigo de descargas acidentais de poluentes; à possibilidade crescente de introdução de espécies exóticas; ao desmantelamento do intercâmbio da fauna entre o rio e as planícies aluviais, provocado pelas mudanças hidrológicas e/ou a eliminação de sedimentos de dragagens nas margens dos rios ou em afluentes secundários.

De acordo com o relatório "Retrato da Navegação no Alto Rio Paraguai" (WWF, 2001), a dragagem do leito do rio modifica as variáveis dependentes dos processos morfológicos, provocando alterações temporárias no equilíbrio sedimentológico e o escoamento tende, em seguida, a restaurar os valores dessas variáveis, o que torna a operação de dragagem repetitiva e sem fim, não se podendo conceber a hidrovia no rio Paraguai sem dragagens periódicas e/ou contínuas. Ainda conforme o referido trabalho, as consequências se tornam novas causas conforme pode ser observado na Figura 8.1 que apresenta a matriz de causas e consequências da dragagem do leito do rio. 


\begin{tabular}{|c|c|c|c|c|c|c|c|c|c|c|c|c|c|}
\hline $\begin{array}{l}\text { Causas } \longrightarrow \\
\text { Consequências }\end{array}$ & 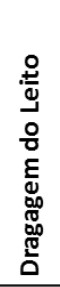 & 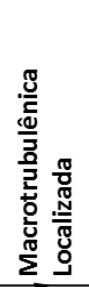 & 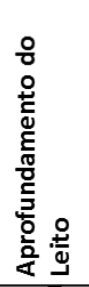 & 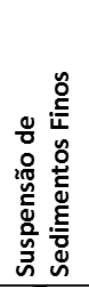 & 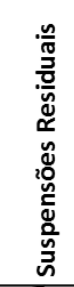 & 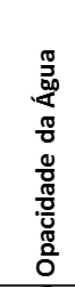 & 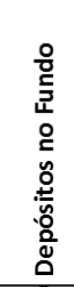 & 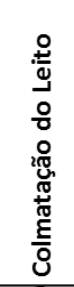 & 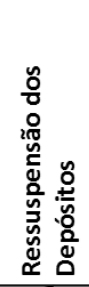 & 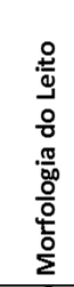 & 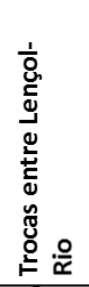 & 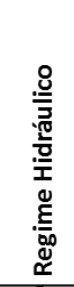 & 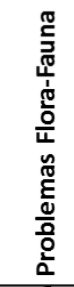 \\
\hline $\begin{array}{l}\text { Macrotrubulênica } \\
\text { Localizada }\end{array}$ & & & & & & & & & & & & & \\
\hline $\begin{array}{l}\text { Aprofundamento } \\
\text { do Leito }\end{array}$ & & & & & & & & & & & & & \\
\hline $\begin{array}{l}\text { Suspensão de } \\
\text { Sedimentos Finos }\end{array}$ & & & & & & & & & & & & & \\
\hline $\begin{array}{l}\text { Suspensões } \\
\text { Residuais }\end{array}$ & & & & & & & & & & $\bullet$ & & • & $\bullet$ \\
\hline Opacidade da Água & & & & & & & & & & & & & \\
\hline $\begin{array}{l}\text { Depósitos no } \\
\text { Fundo }\end{array}$ & & & & & & & & & • & • & & $\bullet$ & $\bullet$ \\
\hline $\begin{array}{l}\text { Colmatação do } \\
\text { Leito }\end{array}$ & & & & & & & & & & $\bullet$ & & & \\
\hline $\begin{array}{l}\text { Ressuspensão dos } \\
\text { Depósitos }\end{array}$ & & & & & & & & • & & & & $\bullet$ & \\
\hline Morfologia do Leito & & & & & & & - & & • & & & $\bullet$ & \\
\hline $\begin{array}{l}\text { Trocas entre } \\
\text { Lençol-Rio }\end{array}$ & & & t. & & & & & $\bullet$ & & • & & & \\
\hline Regime Hidráulico & & & • & & & & $\bullet$ & - & & - & $\bullet$ & & \\
\hline $\begin{array}{l}\text { Problemas Flora- } \\
\text { Fauna }\end{array}$ & & & $\bullet$ & & • & • & $\bullet$ & & $\bullet$ & $\bullet$ & & $\bullet$ & \\
\hline
\end{tabular}

Figura 8.1 - Matriz de causas e consequências da dragagem do leito do rio.

O símbolo - indica a primeira relação entre causas e consequências e as setas partem destas ultimas, agora como causas, para novas consequências provocadas.

Fonte: Wilson-Jr (1996) apud (WWF, 2001)

Com base na Figura 8.1 pode-se observar que a dragagem do leito do rio tem três consequências imediatas: criação de uma macroturbulência localizada; aprofundamento do leito do rio; entrada em suspensão de sedimentos finos. Tais consequências se tornam rapidamente causas de novas situações, onde se destacam os seguintes impactos: surgimento de suspensões residuais; opacidade da água; depósitos sobre o fundo e margens; colmatagem do leito; ressuspensão dos depósitos; modificações morfológicas do trecho do rio; modificações nas trocas 
lençol freático-rio; modificações do regime hidráulico; problemas relacionados com a flora e a fauna (WWF, 2001).

Por sua vez, a disposição do material dragado provoca o aumento do material em suspensão e a perda de habitats. No entanto, existe possibilidade de que ocorram diferentes impactos dependendo do material dragado ser descartado na água, nas margens próximas ou transportado para outra localidade.

Para a disposição em água de material dragado, sem presença significativa de poluentes, um dos argumentos utilizados é que se trata de sedimentos não consolidados, que seriam naturalmente transportados. Neste caso, a dragagem atua apenas como um acelerador, antecipando um fenômeno natural de transporte de sedimentos. Verifica-se na maioria dos casos, que o material dragado é o mesmo que seria transportado naturalmente.

De acordo com USACE (1981), os impactos associados com a disposição do material dragado em terra normalmente envolvem danos menores à flora do que na inundação provocada pelo represamento. Normalmente, áreas de disposição são relativamente pequenas e, assim, tendem a causar menor perda de espécies selvagens. O estudo destaca que a disposição é talvez mais prejudicial quando o local escolhido é uma zona úmida, devido à sensibilidade inerente do ecossistema das zonas úmidas e a presença frequente de espécies ameaçadas de extinção, principalmente aviárias e aquáticas.

Existem, no entanto, medidas de mitigação que podem ser utilizadas para compensar esses impactos. Um bom planejamento pode permitir a seleção de áreas que não são ecologicamente críticas ou o uso do material de uma maneira que pode ser mais benéfica para o ambiente existente ou que possam criar novos habitats. Deve-se notar, contudo, que a seleção de locais alternativos para disposição, por exemplo, locais que podem não ser ecologicamente críticos, muitas vezes envolve algum tipo de trade-off (USACE, 1981).

Estudo realizado pela USACE (2012) para a modernização dos portos e hidrovias nos Estados Unidos verificou que a disposição no passado de material em terra criou novos habitats que poderiam ser mais ou menos desejáveis do que o habitat original, dependendo do local e da sua gestão. Após instituição de leis e ordens executivas mais fortes, a política da USACE nas últimas décadas tem

${ }^{8}$ Trade-off ou tradeoff é uma expressão em inglês que significa o ato de escolher uma coisa em detrimento de outra e muitas vezes é traduzida como "perde-e-ganha". 
enfatizado a proteção das zonas úmidas saudáveis e de contenção e tratamento de sedimentos contaminados. Em 1992, a USACE foi autorizada a usar beneficamente material dragado visando a melhoria do meio ambiente. Atualmente, cerca de 20 a 30 por cento do material dragado está sendo usado beneficamente (USACE, 2012).

Marcela e Claudio (2011), que analisam o caso da Via Navegável Troncal, Seções Santa Fé - Oceano e Santa Fé - Confluência, na Argentina, consideram que o descarte do material dragado no próprio rio é uma contribuição importante por não afetar muito o comportamento fluvial, no sentido de que os sedimentos dragados são componentes do próprio rio e integram o sistema fluvial cujo regime hidrodinâmico, por sua vez, define a composição e características do material. De acordo com os autores, esse tipo de disposição é realizado desde o início da concessão da rota e a qualidade do material coletado nas campanhas de monitoramento nunca alertaram para a necessidade de uma mudança de método de disposição.

\subsubsection{Derrocamento}

O derrocamento é o processo de retirada de pedrais que estão no curso d'água dificultando ou impossibilitando a passagem de embarcações. Uma maneira comum para a retirada do material rochoso consiste na detonação com a utilização de explosivos.

Os derrocamentos, normalmente subaquáticos e realizados a fogo, consistem na detonação de explosivos introduzidos em perfurações realizadas nos pedrais ou lajes do leito do rio e posterior retirada do material detonado. Esse método apresenta os inconvenientes dos gases tóxicos liberados nas explosões, além da possibilidade da ocorrência de danos a estruturas próximas, problemas com vibração e lançamento de fragmentos. Uma alternativa a esse método é a utilização de marteletes hidráulicos para realizar a fragmentação da rocha a ser retirada (BRASIL, 2005). Atualmente já existem várias técnicas para controlar ou mitigar esses impactos, tais como: cortinas de bolhas de ar, técnicas para afugentamento da ictiofauna, entre outros.

De acordo Silva (2004), o derrocamento, dependendo do local e de como é realizado, tem o potencial de provocar aumento na velocidade do fluxo das águas. Alguns afloramentos rochosos podem funcionar como controles naturais da vazão 
do rio. Nesses casos, a retirada do material rochoso pode gerar alterações hidrológicas significativas que devem ser analisadas.

\subsubsection{Barragens}

A construção de barragens é uma das formas de intervenção para aproveitamento dos rios pela navegação. As barragens aumentam a lâmina d'água, controlam a variação do regime hidrológico e possibilitam superar obstáculos à navegação, como quedas e corredeiras. No Brasil, os barramentos apresentam impactos já amplamente estudados pelo setor elétrico. Contudo, barragens para fins de navegação são em geral, de menor porte do que as utilizadas para geração de energia hidroelétrica.

Segundo Brasil (2005), essas barragens para fins de navegação são quase sempre de baixa queda que, quando comparadas com as normalmente construídas pelo setor elétrico acarretam menores impactos ambientais e socioeconômicos, pois, pelo fato do reservatório criado pela construção de tais barragens ser relativamente pequeno, em geral, são menores os problemas como a necessidade de reassentamento de populações e perda de sítios arqueológicos ou histórico e, além disso, essas barragens pouco alteram o transporte de sedimentos e permitem a passagem de peixes migratórios.

Cabe destacar que os principais impactos estão relacionados à construção e ao represamento, como a área alagada, a mudança no regime hidrológico e suas eventuais consequências. As atividades relacionadas à construção de barragens envolvem limpar grandes áreas, abertura de estradas e grandes canteiros de obras.

De acordo com USACE (1981), as atividades de construção da barragem muitas vezes rendem grandes quantidades de sedimentos e consequente turbidez à jusante, o que se configura geralmente um impacto de curto prazo e, uma vez construído, estruturas como barragens e reservatórios servem para reter sedimentos e evitar o seu transporte e deposição a jusante. Além disso, o documento afirma que o maior impacto de barragens é o que se relaciona com a sua operação, pela qual grande área a montante é inundada. Os impactos da inundação para a biota existente estão bem estabelecidos na literatura e, normalmente, resultam na perda de espécies vegetais e de deslocamento/migração e perda de habitat para espécies terrestres. 
O represamento e controle de fluxo podem geralmente diminuir a variação sazonal no regime de escoamento, causando desse modo alterações significativas na qualidade da água e da comunidade biótica aquática. Os impactos não resultam simplesmente do volume de fluxo liberado, mas incluem a taxa de mudança, tempo e duração dos períodos de cheias e secas, qualidade da água, diferenças de temperatura e as velocidades de baixa liberação de barragens. A alteração da região a montante de um ambiente lótico para lêntico, com um subsequentemente aumento significativo em profundidade constitui um grande impacto no habitat aquático (USACE, 1981).

Os efeitos de represamento e bloqueio do curso d'água são permanentes. Os efeitos do represamento na hidráulica do rio, por reservatórios, na sobrevivência das espécies estão bem estabelecidos e são frequentemente citados como um dos principais fatores que contribuem para o declínio das espécies fluviais (USACE, 2012).

Os impactos relacionados à construção de barragens estão entre as principais preocupações na pauta ambiental do transporte hidroviário interior no mundo. No Brasil, não tem sido frequente o uso de barragens para fins de navegação. As barragens são muito utilizadas pelo setor elétrico e as questões ambientais desses projetos são amplamente estudadas. Para o transporte hidroviário, as principais barragens e projetos se encontram na hidrovia do TietêParaná.

\subsection{Normas Ambientais para Dragagem}

Os principais impactos da dragagem apontados na literatura são relacionados ao material dragado, objeto da única norma vigente do Conselho Nacional de Meio Ambiente - CONAMA relacionada direta e especificamente ao licenciamento em hidrovias, a Resolução № 454, de 01 de novembro de 2012, que estabelece as diretrizes gerais e os procedimentos referenciais para o gerenciamento do material a ser dragado em águas sob jurisdição nacional.

A maior parte do material dragado em todo o mundo é, por natureza, semelhante aos sedimentos não perturbados nas águas costeiras e interiores e, portanto ausentes de contaminantes. No entanto, uma proporção menor de material dragado, é contaminada pela atividade antrópica em tal grau que devem se 
considerar restrições ambientais à eliminação ou uso desses sedimentos (IMO, 1996). Para esses casos, em consonância com o princípio da precaução, é justificada a adoção de medidas adequadas para proteger o meio ambiente, na proporção dos riscos decorrentes de um determinado projeto (PIANC, 2008a).

Segundo PIANC (2008a), a experiência demonstrou que a obtenção de um equilíbrio entre as precauções razoáveis e desenvolvimento sustentável pode ser muito difícil. De acordo com o documento, assumir uma atitude de "precaução excessiva" pode majorar os custos dos projetos de dragagem desnecessariamente, levar a longos atrasos e não promover, de forma eficiente, benefício ambiental. Essa noção se reflete na avaliação do impacto de um projeto e, em especial, na avaliação de risco que tenta encontrar um equilíbrio entre impactos ambientais e benefícios sociais. Conclui-se, portanto, que, aliado ao princípio da precaução, é recomendável aplicar os demais princípios do direito, tais como eficiência, razoabilidade e proporcionalidade.

A dragagem e disposição do material dragado podem gerar impactos sobre meio ambiente, pois envolvem, inerentemente, perturbação de substratos existentes. Para evitar ou mitigar esses impactos, algumas normas nacionais e internacionais foram desenvolvidas. Isso resultou em procedimentos definidos em instrumentos normativos, tais como: a Convenção sobre Prevenção da Poluição Marinha por Alijamento de Resíduos e Outras Matérias (Convenção de Londres, 1972), promulgada pelo Decreto 87.566/1982, e a Convenção das Nações Unidas sobre o Direito do Mar (1982), ratificada em 1988 e em vigor no Brasil pelo Decreto $1.530 / 1995$.

Observa-se que normas internacionais tratam, na sua maioria, dos aspectos relacionados às questões marítimas. Isso se deve ao fato de os problemas ocorridos com sedimentos contaminados em dragagens portuárias serem mais frequentes $\mathrm{e}$ conhecidos. Pelos mesmos motivos, estudos científicos também abordam preponderantemente os dados de dragagens marítimas e do alijamento no mar.

Motivados pelos tratados e convenções internacionais e pela Política Nacional do Meio Ambiente, iniciou-se no início da década passada, a elaboração de uma resolução nacional no Conselho Nacional de Meio Ambiente - CONAMA. As resoluções que resultaram dessa iniciativa e informações sobre o processo de elaboração são apresentados a seguir. 


\subsubsection{Elaboração e Revisão das Resoluções}

Em 2002, o Conselho Nacional de Meio Ambiente - CONAMA - iniciou um trabalho para a elaboração de uma Resolução que tinha por objetivo dispor sobre as Normas para Licenciamento Ambiental de Obras de Dragagem e Gestão do Material Dragado em Águas Jurisdicionais Brasileiras. A primeira minuta tinha a seguinte ementa: "Minuta de Resolução que "Dispõe sobre as Normas para Licenciamento Ambiental de Obras de Dragagem e Gestão do Material Dragado em Águas Jurisdicionais Brasileiras"”.

Durante as atividades o foco foi alterado e em 28 de agosto de 2003 foi aprovada pela Câmara Técnica de Controle e Qualidade Ambiental do CONAMA uma minuta de resolução que dispunha sobre diretrizes gerais para a avaliação do material a ser dragado em águas jurisdicionais brasileiras, visando o gerenciamento de sua disposição.

Em 2004, foi aprovada e publicada a Resolução nํ34, de 25 de março de 2004, que estabelecia as diretrizes gerais e os procedimentos mínimos para a avaliação do material a ser dragado em águas jurisdicionais brasileiras.

Essa resolução previa sua revisão em cinco anos, objetivando 0 estabelecimento de valores orientadores nacionais para a classificação do material a ser dragado, pois até então não havia séries históricas nacionais sobre contaminação em sedimentos dragados. Por esse motivo foram adotados, inicialmente, níveis de classificação dos sedimentos baseados na experiência dos Estados Unidos e do Canadá. Determinava ainda que o Instituto Brasileiro do Meio Ambiente e dos Recursos Naturais Renováveis - IBAMA deveria normatizar a forma de apresentação dos dados gerados para classificação do material dragado, monitoramento das áreas de dragagem e de disposição, de modo que os dados gerados pelos órgãos ambientais competentes fossem comparados, quando da revisão desta Resolução.

O Banco de Dados previsto não foi criado e, para suprir essa lacuna, visando dar subsídio ao processo de revisão da resolução a Secretaria Especial de Portos da Presidência da República contratou a elaboração do Estudo Técnico-Científico de Caracterização de Sedimentos e Fontes de Contaminação das Regiões Portuárias Brasileiras. O estudo consistiu na análise dos dados ambientais existentes e estruturação de um Banco de Dados Ambientais de Sedimentos de 
Dragagens em Portos Marítimos Brasileiros. Inicialmente, foram incluídas no banco de dados informações de características dos sedimentos de oito dos principais portos.

Em 2008 foi criado Grupo de Trabalho no âmbito da Câmara Técnica de Controle e Qualidade Ambiental para revisão da Resolução CONAMA no 344/04, conforme previsto. Apesar dos grandes avanços, o grupo não concluiu os trabalhos no tempo previsto, o que gerou a aprovação da Resolução no 421, de 03 de fevereiro de 2010, dilatando o prazo para revisão e atualização em mais 24 meses e prorrogando a validade os valores orientadores nacionais para a classificação do material a ser dragado, estabelecidos na Resolução no 344, de 25 de março de 2004, até que fosse efetuada a sua revisão parcial ou total.

Em abril de 2011 foi criado novo grupo de trabalho para revisão e atualização da Resolução CONAMA no 344 com o objetivo de cumprir o estabelecido na Resolução CONAMA no 421 a partir da integração dos diversos segmentos (área ambiental, transportes, portos, sociedade civil organizada, academia, atividade privada) e à luz de discussões a respeito das demandas dos diferentes setores, dos ganhos e das dificuldades encontradas na aplicação da Resolução CONAMA no 344.

Como resultado do último Grupo de Trabalho, foi aprovada e publicada a Resolução CONAMA № 454, de 01 de novembro de 2012, que estabelece as diretrizes gerais e os procedimentos referenciais para o gerenciamento do material a ser dragado em águas sob jurisdição nacional.

\subsubsection{Resolução CONAMA ํo 344/2004}

Considerando a necessidade de subsidiar e harmonizar a atuação dos órgãos ambientais competentes no que se refere ao processo de licenciamento ambiental das atividades de dragagem, a Resolução CONAMA no 344, de 25 de março de 2004, estabeleceu as diretrizes gerais e procedimentos mínimos para a avaliação do material a ser dragado visando ao gerenciamento de sua disposição em águas jurisdicionais brasileiras.

Para orientar o gerenciamento da disposição do material dragado durante o processo de licenciamento ambiental foi definida na Resolução, e aplicada como principal instrumento, a classificação do material ser dragado, empregando critérios 
de qualidade a partir de dois níveis de concentração de elementos e compostos contaminantes. Os critérios de qualidade fundamentam-se na comparação dos resultados da caracterização do material a ser dragado, com os valores orientadores para os níveis 1 e 2 previstos na Tabela III do Anexo da Resolução.

O Nível 1 é o limiar abaixo do qual prevê-se baixa probabilidade de efeitos adversos à biota e o Nível 2 limiar acima do qual prevê-se um provável efeito adverso à biota. Os valores orientadores em que se baseiam a resolução e a definição dos níveis são oriundos de três estudos: CANADA (2002), LONG et al. (1995) e FDEP (2004).

Long et al. (1995) determinaram três faixas de concentrações para 28 substâncias ou grupos químicos com base em uma avaliação de dados existentes. Os intervalos foram definidos por dois valores de referência, menores que o $10^{\circ}$ percentil (Effects Range-Low - ERL) e menores que o 50 percentil (Effects RangeMedian - ERM) da distribuição dos dados de efeitos.

As concentrações abaixo do valor de ERL representam um intervalo de "efeitos mínimos", uma faixa destinada a estimar as condições em que os efeitos seriam raramente observados. Concentrações iguais e acima do ERL e abaixo da ERM representam uma faixa de "efeitos possíveis" dentro da qual teria efeitos ocorrem ocasionalmente. Finalmente, concentrações equivalentes e acima do valor de ERM representam uma faixa de "efeitos prováveis" dentro da qual efeitos ocorreriam com frequência (LONG et al., 1995).

A incidência de efeitos biológicos foi quantificada para cada um desses intervalos como uma estimativa da precisão das referências. O estudo constatou que a incidência de efeitos geralmente foi abaixo de $25 \%$ em concentrações inferiores aos valores ERL. Para a maioria das substâncias químicas, a incidência de efeitos aumentou significativamente com o aumento das concentrações, muitas vezes superiores a $75 \%$ (ocasionalmente 100\%) em concentrações que excederam os valores ERM. No entanto, para algumas substâncias químicas (especialmente mercúrio, níquel, PCBs total, DDT total, e p, p'-DDE) as relações entre as suas concentrações e a incidência de efeitos foram relativamente fracas (LONG et al., 1995).

Long et al. (1995) ressaltam que as referências numéricas devem ser utilizadas como ferramentas de triagem informal nas avaliações ambientais. Elas não se destinam a impedir o uso de testes de toxicidade ou outras medidas de 
efeitos biológicos. As orientações devem ser acompanhadas das informações sobre a incidência de efeitos. Os dados de incidência percentuais podem ser úteis para estimar a probabilidade de observar efeitos adversos semelhantes dentro das faixas de concentração definidas de contaminantes particular (LONG et al., 1995).

Por sua vez, o Canadian Council of Ministers of the Environment - CCME derivou dois valores de referência para cerca de 30 substâncias em sedimentos de água doce e marinhos: um nível de efeito limiar (Threshold Effect Level - TEL) e um nível de efeito provável (Probable Effect Level - PEL). Estes dois valores foram adotados para a avaliação da qualidade do sedimento em Quebec, e três outros níveis foram derivados para definir todos os níveis de intervenção necessária para a gestão de sedimentos sob uma diversidade de contextos. Os três novos critérios de qualidade de sedimento foram definidos usando o banco de dados do CCME e um método de cálculo semelhante ao usado para determinar o TEL e o PEL. Eles são: (1) o nível de efeito raros (Rare Effect Level - REL), (2) o nível de efeito ocasionais (Occasional Effect Level - OEL), e (3) o nível de efeito frequentes (Frequent Effect Level - FEL). Este conjunto de critérios constitui uma ferramenta de triagem para avaliar o grau de contaminação do sedimento (CCME, 2007).

O CCME destaca que empregados em conjunto com os níveis de background natural, esses critérios de qualidade podem evitar a contaminação dos locais que são sensíveis às entradas de contaminantes antropogênicos. Os critérios podem também ser combinados com outras ferramentas de avaliação, como testes de toxicidade e estudos de campo biológicos para determinar o método de gestão mais adequado para o material dragado com base em seu grau de contaminação. Os critérios de qualidade de sedimentos também podem servir como indicadores das medidas corretivas necessárias em locais contaminados e ajudar a definir os objetivos da recuperação (CCME, 2007).

\subsubsection{Resolução CONAMA ํo $454 / 2012$}

A Resolução no 454, de 01 de novembro de 2012, amplia o escopo regulamentado em relação à Resolução 344 , dando foco no gerenciamento do material dragado, mas assim como a revogada Resolução e ao contrário do previsto na primeira proposta, também não regulamenta todo o licenciamento da dragagem. 
O objeto de regulação foi ampliado. Diferentemente da Resolução № 344 que estabelecia os procedimentos mínimos para a avaliação do material a ser dragado visando ao gerenciamento de sua disposição em águas jurisdicionais brasileiras, a nova Resolução estabelece as diretrizes gerais e os procedimentos referenciais para o gerenciamento do material a ser dragado em águas sob jurisdição nacional, bem como a forma de sua disposição final.

A nova resolução define o conteúdo do plano conceitual de dragagem, com informações para caracterizar as intervenções e os processos. Além disso, reconhece alguns dos casos em que a caracterização ambiental deve ser dispensada. Nesses casos a caracterização não se faz necessária, em suma, devido à emergência da situação ou porque o material já é conhecido ou a área apresenta pequenos riscos de material contaminado. Dessa forma, a norma retira dos casos previstos a exigência de caracterização, em situações em que essa é impossibilitada ou agrega pouco valor à tomada de decisão.

A Resolução adota uma sequência lógica para a tomada de decisão que contempla as dispensas, caracterizações, classificação e formas disposição do material dragado. Define mais claramente os casos em que não há necessidade da caracterização ou de algum tipo de caracterização para a tomada de decisão. Para a classificação a norma deixa explícito que os níveis de classificação dos sedimentos são valores referenciais, devendo ser tomados como mais uma linha de evidência para a definição da disposição do material dragado. No tocante à disposição, a norma passa a incorporar a disposição em terra e privilegia a utilização do material dragado para algum tipo de uso benéfico. Além disso, foram alterados alguns valores de referência para águas marítimas, com base nos valores internacionais e na experiência nacional.

\subsubsection{Considerações}

Nenhuma das duas Resoluções do CONAMA que dispõem sobre dragagem considera completamente outros fatores e impactos associados à dragagem além da qualidade dos sedimentos. Cabe destacar que a caracterização e classificação dos sedimentos são apenas parte do gerenciamento do material dragado que, por sua vez, é parte do licenciamento, um dos fatores de um processo mais amplo. 
Outra questão importante não abordada nas Resoluções é o controle das fontes de poluição. Grande parte dos poluentes encontrados no material dragado é proveniente de outras atividades, prejudicando o meio ambiente e onerando a dragagem.

\subsection{Navegação}

É importante destacar que a navegação requer cuidados, principalmente por utilizar o curso d'água como suporte. Dois são os principais grupos de impactos diretos da navegação ao meio ambiente. O primeiro compreende os impactos da embarcação, que abrange os impactos causados pela poluição gerada nas embarcações e os impactos gerados pelo movimento das embarcações no curso d'água, principalmente sobre a biota aquática e às margens. Em relação a esses impactos, deve-se melhorar a educação ambiental e buscar desenvolver embarcações que considerem as características ambientais e, consequentemente, provoquem menos impactos. As embarcações devem ser adaptadas às vias, e não ao contrário. Em relação a esse tema, Padovezi (2003) fez um abrangente trabalho. O segundo grupo de impactos consiste nos impactos potenciais, gerados pelo risco de acidentes. Esse também já foi tema de diversas pesquisas, conforme apresentado ao longo deste trabalho.

No Brasil e no exterior existem várias normas que tratam da segurança da Navegação. No Brasil, a lei no 9.537, de 11 de dezembro de 1997, dispõe sobre a segurança do tráfego aquaviário em águas sob jurisdição nacional. A referida lei é regulamentada pelo Decreto ํㅡㄴ.596, de 18 de maio de 1998.

A lei 9.537/97 estabelece o seguinte em seu artigo 3‥

"Art. $3^{\circ}$ Cabe à autoridade marítima promover a implementação e execução
desta Lei, com o propósito de assegurar a salvaguarda da vida humana e a
segurança da navegação, no mar aberto e hidrovias interiores, e a
prevenção da poluição ambiental por parte de embarcações, plataformas
ou suas instalações de apoio".

Além dessas e de outras normas mais específicas, existem as Normas da Autoridade Marítima - NORMAM, emitidas pela Diretoria de Hidrografia e Navegação da Marinha do Brasil, que abordam temas diversos relacionados à navegação, inclusive quanto à segurança, conforme se pode observar no Quadro 8.1 . 
Quadro 8.1 - Normas da Autoridade Marítima - NORMAM.

\begin{tabular}{|c|c|}
\hline NORMAM & Normas para \\
\hline NORMAM-01 & Embarcações Empregadas na Navegação em Mar Aberto \\
\hline NORMAM-02 & Embarcações Empregadas na Navegação Interior \\
\hline NORMAM-03 & $\begin{array}{l}\text { Amadores, Embarcações de Esporte e/ou Recreio e para Cadastramento e } \\
\text { Funcionamento das Marinas, Clubes e Entidades Desportivas Náuticas }\end{array}$ \\
\hline NORMAM-04 & Operação de Embarcações Estrangeiras em Águas Jurisdicionais Brasileiras \\
\hline NORMAM-05 & Homologação de Material (Coletes, Bóias, Balsas Salva-Vidas, etc.) \\
\hline NORMAM-06 & $\begin{array}{l}\text { Reconhecimento de Sociedades Classificadoras para Atuarem em Nome do Governo } \\
\text { Brasileiro }\end{array}$ \\
\hline NORMAM-07 & Atividades de Inspeção Naval (Auto de Infração) \\
\hline NORMAM-08 & $\begin{array}{l}\text { Tráfego e Permanência de Embarcações em Águas Jurisdicionais Brasileiras } \\
\text { (Despacho de Embarcações) }\end{array}$ \\
\hline NORMAM-09 & Inquéritos Administrativos (Inquérito) \\
\hline NORMAM-10 & $\begin{array}{l}\text { Pesquisa, Exploração, Remoção e Demolição de Coisas e Bens Afundados, } \\
\text { Submersos, Encalhados e Perdidos }\end{array}$ \\
\hline NORMAM-11 & $\begin{array}{l}\text { Obras, Dragagem, Pesquisa e Lavra de Minerais Sob, Sobre e às Margens das } \\
\text { Águas sob Jurisdição Brasileira }\end{array}$ \\
\hline NORMAM-12 & Serviço de Praticagem \\
\hline NORMAM-13 & Aquaviários \\
\hline NORMAM-14 & Cadastramento de Empresas de Navegação, Peritos e Sociedades Classificadoras \\
\hline NORMAM-15 & Atividades Subaquáticas \\
\hline NORMAM-16 & $\begin{array}{l}\text { Estabelecer Condições e Requisitos para Concessão e Delegação das Atividades de } \\
\text { Assistência e Salvamento de Embarcação, Coisa ou Bem em Perigo no Mar, nos } \\
\text { Portos e Vias Navegáveis Interiores }\end{array}$ \\
\hline NORMAM-17 & Auxílios à Navegação \\
\hline NORMAM-19 & Atividades de Meteorologia Marítima \\
\hline NORMAM-20 & Gerenciamento da Água de Lastro de Navios \\
\hline NORMAM-21 & Uso de Uniformes da Marinha Mercante Nacional \\
\hline NORMAM-22 & Normas para o Cerimonial da Marinha Mercante Nacional \\
\hline NORMAM-23 & Controle de Sistemas Antiincrustantes Danosos em Embarcações \\
\hline NORMAM-24 & $\begin{array}{l}\text { Credenciamento de Instituições para Ministrar Cursos para Profissionais Não- } \\
\text { Tripulantes e Tripulantes Não-Aquaviários }\end{array}$ \\
\hline NORMAM-25 & Levantamentos Hidrográficos \\
\hline NORMAM-26 & Serviço de Tráfego de Embarcações \\
\hline NORMAM-27 & Homologação de Helipontos Instalados em Embarcações e em Plataformas \\
\hline NORMAM-28 & Navegação e Cartas Náuticas \\
\hline NORMAM-29 & Transporte de Cargas Perigosas \\
\hline NORMAM-30 & Ensino Profissional Marítimo \\
\hline
\end{tabular}




\section{AVALIAÇÃO AMBIENTAL DE PROJETOS HIDROVIÁRIOS}

Conforme exposto ao longo deste trabalho, o transporte hidroviário apresenta vários benefícios ambientais, mas as intervenções necessárias para garantir ou promover a navegabilidade podem causar também impactos negativos. Dessa forma, é recomendável melhorar o planejamento para a utilização desse modo e aplicar uma gestão ambiental mais eficaz. Adicionalmente, mais do que apenas cumprir normas legais vigentes, é desejável que a realização de licenciamento ambiental seja efetiva no controle ambiental.

Convém ressaltar que planejamento e gestão ambiental adequados devem estar presentes em todas as situações, inclusive naquelas para as quais não há necessidade de licenciamento ambiental. Este capítulo abordará os dois temas, o planejamento e o licenciamento ambiental de projetos hidroviários.

\subsection{Planejamento}

Tão importante e talvez ainda mais efetivo do que definir critérios e procedimentos para o licenciamento ambiental é promover uma evolução no processo de planejamento do setor hidroviário, desde a definição das políticas à execução dos projetos. Alguns estudos já abordaram a necessidade de realizar o planejamento integrado dos projetos e destacaram as vantagens dessa abordagem em relação ao método tradicional de desenvolvimento de projetos, dentre os quais, podemos destacar os seguintes: ECMT (2006), PIANC (2008b), ICPDR (2010) e European Commission (2012).

A Conferência Europeia dos Ministros de Transportes (European Conference of Ministers of Transport - ECMT) elaborou o documento "Inland Waterways \& Environmental Protection" (ECMT, 2006) que reúne práticas e experiências adotadas em alguns países selecionados, entre outros itens, sobre as questões ambientais relacionadas ao transporte hidroviário interior. O documento ressalta que o planejamento estratégico para o desenvolvimento de bacias hidrográficas que integre os aspectos econômicos, sociais e ambientais poderia facilitar a construção de consensos sobre projetos desenvolvidos individualmente.

Já a Associação Mundial para a Infraestrutura de Transporte Aquaviário PIANC emitiu um documento intitulado "Working with Nature" (PIANC, 2008b), que 
propõe uma importante mudança na abordagem para o desenvolvimento da navegação buscando maximizar as oportunidade e reduzir as frustrações por meio do planejamento integrado do projeto.

Também a fim de proporcionar mais orientações sobre como aplicar os princípios de planejamento integrado, foi elaborado, no âmbito do projeto PLATINA ${ }^{9}$, o "Manual on Good Practices in Sustainable Waterway Planning" (ICPDR, 2010). Publicado em 2010, o manual fornece um guia prático para os planejadores da navegação fluvial em toda a Europa sobre a forma de organizar e implementar um processo de planejamento equilibrado e integrado para as atividades da navegação fluvial.

Por sua vez, o "Guidance document on inland waterway transport and Natura 2000" (EUROPEAN COMMISSION, 2012) tem foco na relação dos projetos com o Natura $2000^{10}$, mas aborda de forma ampla o planejamento dos projetos para infraestrutura hidroviária. O documento enfatiza as vantagens do planejamento integrado no desenvolvimento desses projetos.

Essas abordagens focam principalmente no planejamento e desenvolvimento do projeto. Cabe destacar ainda que esses estudos foram desenvolvidos na Europa, onde o transporte hidroviário interior já vem sendo desenvolvido há muito tempo e as políticas e diretrizes para o THI já estão consolidadas.

No atual cenário brasileiro, observa-se a necessidade de desenvolver, além do planejamento integrado dos projetos, um planejamento estratégico que considere todas as dimensões (social, econômica, técnica e ambiental) antes da própria definição de cada projeto. Nesse sentido, sugere-se uma proposta mais adaptada à realidade brasileira para auxiliar o planejamento do setor hidroviário.

Trata-se de uma proposta inicial, adaptada ao atual contexto brasileiro, com o objetivo de contribuir para a melhora do planejamento do setor hidroviário no País,

\footnotetext{
${ }^{9} \mathrm{O}$ consórcio PLATINA é uma plataforma para a implementação do programa de ação NAIADES UE financiado no âmbito do Programa FP7. O projeto visa promover e fortalecer um transporte interior ambientalmente amigável na Europa em 5 áreas: mercado, frota, empregos e qualificações, imagem e infra-estrutura.

O plano de ação NAIADES é uma iniciativa para aumentar o uso da navegação interior como parte de soluções intermodais de carga, a fim de criar uma rede de transportes competitiva sustentável e ambientalmente amigável no países Europeus.

O consórcio núcleo é formado por via Donau (Áustria) como coordenador, Voies navigables de France (França), Bundesverband der Deutschen Binnenschiffahrt (Alemanha), Promotie Binnenvaart Vlaanderen (Bélgica) e do Rijkswaterstaat Centre for Transport and Navigation (Holanda).

${ }^{10}$ A Natura 2000 é uma rede de áreas protegidas no território dos Estados-Membros da União Europeia.
} 
incorporando questões ambientais, que não exclui a possibilidade de uso das boas práticas internacionais, como as supracitadas. A abordagem proposta para ser utilizada no planejamento do setor hidroviário é ilustrada na Figura 9.1.

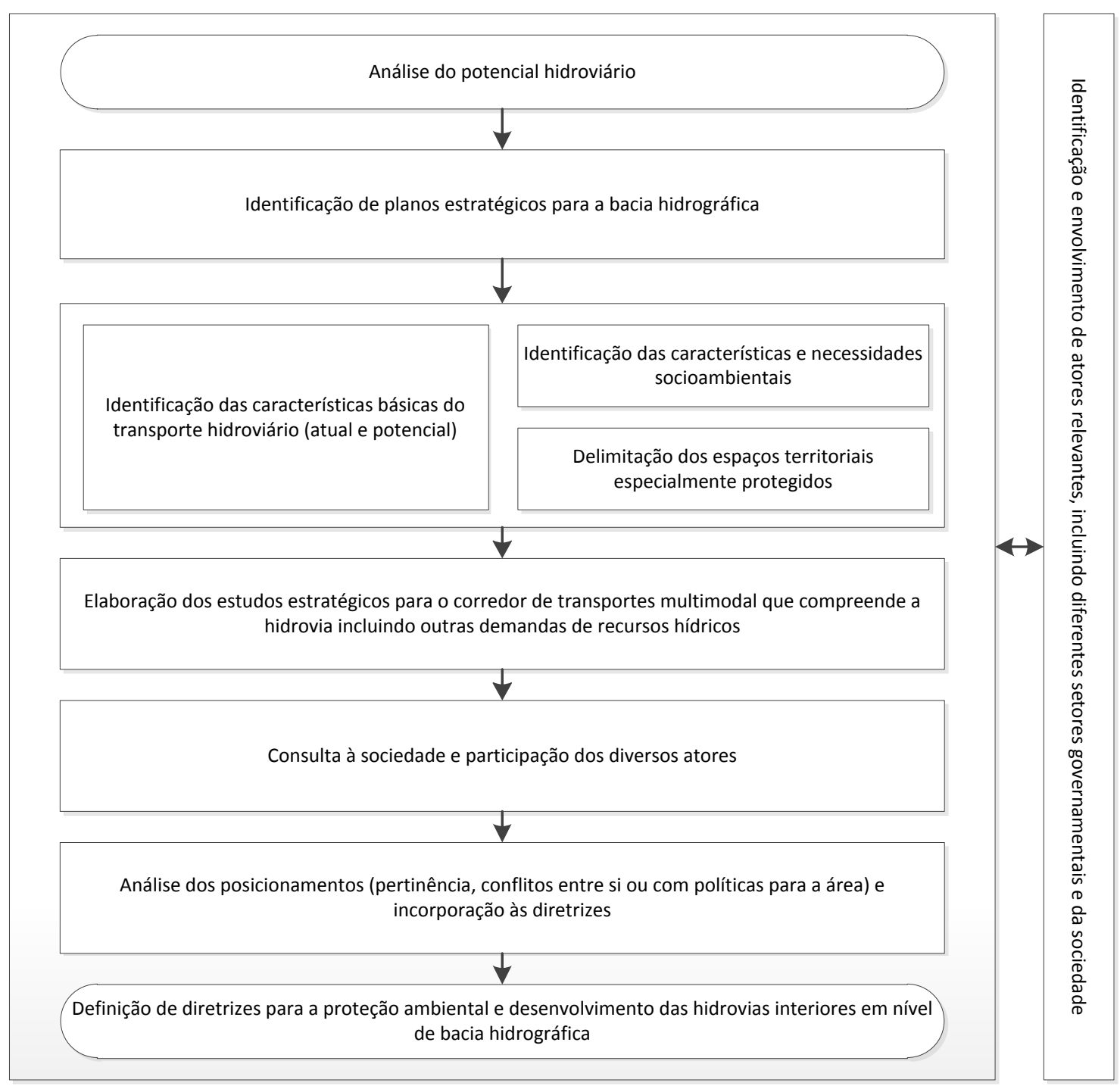

Figura 9.1 - Abordagem para o planejamento no setor de transporte hidroviário interior. 
Não se deve deixar iludir pela simplicidade da proposta, pois sua aplicação conta com variáveis complexas, como a participação social em vários momentos, a necessidade de informações e equipes intersetoriais, além da solução de conflitos de diversas ordens. A complexidade nesses casos deve diminuir com o tempo e com a aplicação, pois sua origem reside na falta de cultura de aplicação dessas práticas no Brasil. No entanto, com o uso e o desenvolvimento de novas técnicas, esses pontos poderão se incorporar à rotina e consequentemente, tornarem-se naturalmente aplicáveis.

A proposta apresentada se inicia com a análise do potencial hidroviário, pois só há sentido em evocar transporte hidroviário em locais onde há potencial para a utilização desse modo. Após a identificação de potencial para o transporte hidroviário, sugere-se identificar outros planos estratégicos para a bacia, tais como do setor elétrico, ambiental, agropecuário, entre outros. Esses podem influenciar ou serem influenciados, positiva ou negativamente, pelos projetos hidroviários.

Anteriormente ao projeto hidroviário e em paralelo ao levantamento das necessidades da infraestrutura de transportes, é muito importante identificar, em um nível estratégico, necessidades e características ambientais relevantes, especialmente áreas mais vulneráveis ou merecedoras de cuidados especiais. A partir desses dados, já seria possível elaborar estudos estratégicos para o corredor de transporte multimodal.

Uma etapa importante em processos de planejamento inclui a consulta participativa aos diversos setores da sociedade. Cabe ressaltar que o envolvimento de atores relevantes, incluindo diferentes setores governamentais e da sociedade, deve ser constante durante todo o processo, de acordo com a fase em que se encontra.

$O$ desenvolvimento do procedimento de planejamento deve envolver a participação efetiva dos principais setores do Governo e da sociedade. Essa participação, bem como uma análise que integre o econômico, ambiental e social poderia facilitar a construção de consensos no desenvolvimento de projetos individuais. Em especial, é importante que os setores ambiental e hidroviário trabalhem juntos para produzir em nível de bacia hidrográfica, estratégias para a proteção ambiental e desenvolvimento das hidrovias interiores. Além desses dois setores, devem estar presentes os atores de outros setores usuários dos recursos 
hídricos. Cabe ressaltar novamente, que a navegação pode ser utilizada como uma estratégia de desenvolvimento e proteção ambiental da bacia.

Dessa forma, entende-se que é possível obter, satisfatoriamente, diretrizes, em nível de bacia hidrográfica, tanto para a proteção ambiental como para o desenvolvimento do transporte hidroviário interior.

\subsection{Licenciamento Ambiental}

O licenciamento é o procedimento administrativo pelo qual o órgão ambiental competente autoriza a localização, instalação, ampliação e operação de empreendimentos e atividades utilizadoras de recursos ambientais, consideradas efetiva ou potencialmente poluidoras ou daquelas que, sob qualquer forma, possam causar degradação ambiental.

O licenciamento ambiental é um importante instrumento da Política Nacional do Meio Ambiente - PNMA e foi um grande avanço na proteção ambiental. Deve se apoiar em outros instrumentos de política, planejamento e gestão ambiental, mas não deve, de forma alguma, substituí-los. Também deve ser um espaço em que haja diálogo e participação popular, mas não o único e nem mesmo o primeiro momento dessa participação, a qual deve ocorrer em vários momentos, iniciando na concepção das políticas públicas.

Cabe ressaltar que o licenciamento ambiental não é o único instrumento de gestão ambiental ou da Política Nacional do Meio Ambiente. Outro importante instrumento da PNMA é a avaliação de impactos ambientais que pode e deve ser aplicada em outros momentos e procedimentos, que não o licenciamento. Um exemplo é a aplicação de técnicas de avaliação de impactos ambientais em etapas de planejamento, deixando esse instrumento de ser aplicado em um procedimento configurado como uma decisão submetida e passando a ser aplicado como uma decisão compartilhada, onde se busque obter uma análise ampla dos aspectos técnicos, ambientais, econômicos, sociais e políticos dos empreendimentos e suas inter-relações. Desse modo, poderia se esperar que as decisões fossem focadas na efetividade das ações em termos técnico-ambientais e menos na elaboração e análise de documentos para simples aprovação. 


\subsubsection{Objeto do Licenciamento Ambiental}

O processo de licenciamento ambiental é apontado, em alguns momentos, como um dos principais fatores que afetam o desenvolvimento das hidrovias interiores. Esse procedimento tem sido foco de diversas controvérsias. Um dos principais pontos de indefinição em relação ao processo de licenciamento está na definição do objeto a ser licenciado. Assim, essa definição é fundamental.

Por um lado, existem argumentos que consideram o objeto do licenciamento a própria hidrovia. Por outro, existem aqueles que argumentam que são as obras hidroviárias os objetos dos licenciamentos ambientais. Independente do objeto, ainda há divergências de como o processo de licenciamento deve ocorrer.

O IBAMA já apresentou diferentes posicionamentos em relação à questão. Em 2006, foi emitido despacho ${ }^{11}$ com a finalidade de orientar os procedimentos a serem adotados no licenciamento ambiental de Hidrovias. De acordo com o referido despacho, entre outras, são as seguintes as orientações:

- Não há licenciamento ambiental de hidrovias, aqui entendidos os rios, lagos, canais, lagoas, baías e angras onde se exerce a navegação como decorrência do aproveitamento das condições naturais oferecidas pelas águas.

- Deverão ser licenciadas todas as atividades relacionadas ao uso de hidrovias que apresentem potencial poluidor ou degradador do meio ambiente, tais como dragagens, derrocamentos, barragens, eclusas, portos, oficinas e estaleiros.

- Em cumprimento à Resolução Conama 01/86 dependerão obrigatoriamente da elaboração de EIA e respectivo RIMA o licenciamento de portos, terminais de minério, petróleo e produtos químicos, abertura de canais para a navegação, retificação de curso d'água, abertura de barras e embocaduras, diques.

- Dragagens e derrocamentos, quando considerados de significativo impacto ambiental também dependerão da elaboração de EIA e respectivo RIMA.

\footnotetext{
${ }^{11}$ Despacho emitido em 25/07/2006, pelo Diretor de Licenciamento Ambiental do IBAMA, Luiz Felipe Kunz Júnior, com base na Informação Técnica 003/2005/COAIR/CGLIC e o entendimento estabelecido pela Procuradoria Geral Federal, de lavra do Procurador Federal Valdeir Salviano da Costa, datado de 15/12/2004.
} 
- Os Estudos de Impacto Ambiental dos empreendimentos citados nos dois itens anteriores (ou seja, quando há necessidade de EIA/RIMA) deverão seguir as diretrizes gerais estabelecidas pelo artigo $5^{\circ}$ da Resolução Conama 01/86, considerando em todos os casos a Bacia Hidrográfica na qual se localiza.

- Hidrovias artificiais dependerão de licenciamento prévio, de instalação e de operação, sendo considerados em todos os casos empreendimentos de significativo impacto ambiental, sujeitos à elaboração de EIA e RIMA.

- A navegação não se trata de atividade sujeita à licenciamento ambiental, por não estar descrita no anexo I da Resolução Conama 237/97. A Lei 9.074, no seu artigo $2^{\circ} \S 2^{\circ}$, tem a seguinte redação: "Independe de concessão, permissão ou autorização o transporte de cargas pelos meios rodoviário e aquaviário."

- De acordo com a resolução Conama 237/97, em seu artigo 12 §2º, poderá ser adotado licenciamento único para um conjunto de atividades similares, desde que requerido pelo empreendedor (Exemplo: dragagem em vários pontos do mesmo rio, ou dragagens e derrocamentos).

Por outro lado, a Coordenação de Licenciamento de Transportes do IBAMA se posicionou por meio de Nota Técnica ${ }^{12}$ no sentido do licenciamento ambiental da hidrovia. Segundo o posicionamento exposto, os licenciamentos de empreendimentos isolados não permitem que se obtenha uma visão do conjunto, sendo incapazes de avaliar impactos sinérgicos provocados pelos empreendimentos e impactos relacionados ao incremento no tráfego de embarcações. Assim, defendem que as hidrovias devem ser submetidas ao procedimento de licenciamento ambiental, com regularização das hidrovias já existentes e avaliação de viabilidade no caso de implantação de novas hidrovias.

No mesmo documento, sugerem que as hidrovias existentes devem passar por um processo de regularização ambiental. Para isso, discorrem sobre como acreditam que deve ser a regularização das hidrovias, conforme reproduzido no trecho a seguir:

A regularização das hidrovias existentes deve estar condicionada a elaboração de um estudo ambiental, não necessariamente EIA/RIMA, que apresente uma caracterização da hidrovia e seus usos (tipos de embarcações que trafegam por ela, tipos de cargas, pontos críticos a

${ }^{12}$ Nota Técnica no 103/2009 - COTRA/CGTMO/DILIC/IBAMA, emitida em 10 de setembro de 2009. 
navegação e obras de engenharia necessárias, localização dos terminais portuários, estimativas de tráfego, etc), bem como, diagnóstico do meio ambiente na qual ela se insere, estimativa da capacidade de suporte do meio a navegação: identificação de passivos ambientais e impactos gerados pela navegação comercial, proposição de medidas mitigadoras e programas de monitoramento de forma a minimizar e acompanhar esses impactos. (BRASIL, 2009)

Ainda de acordo com esse documento, a partir da regularização e obtenção de licença de operação para a hidrovia, intervenções rotineiras necessárias à segurança da navegação (dragagens de manutenção, serviços de manutenção da sinalização, etc.) deverão estar incluídas na LO. Dessa forma, não há necessidade de serem conduzidas através de licenciamentos separados.

$\mathrm{Na}$ sequência, argumenta que empreendimentos de significativo impacto ambiental que não se enquadrem em serviços de manutenção da hidrovia existente devem ser submetidos a processo de licenciamento independente, com a realização de estudo ambiental voltado à identificação dos impactos específicos desses empreendimentos. Entre outros, enquadram-se nessa condição a instalação de novos terminais portuários, construção de eclusas e derrocamentos. Por fim, posiciona-se no sentido de que a implantação de novas hidrovias em locais onde atualmente não existe navegação comercial regular deve ser condicionada à apresentação de EIA/RIMA que considere toda a área de abrangência da hidrovia e as intervenções necessárias à sua implantação (BRASIL, 2009).

Observa-se, assim, dois posicionamentos essencialmente divergentes, em relação ao objeto de licenciamento de empreendimentos hidroviários. No primeiro, a hidrovia, considerada o local onde ocorre a navegação, não é licenciável, sendo passíveis de licenciamento todas as atividades relacionadas ao uso de hidrovias que apresentem potencial poluidor ou degradador do meio ambiente. No segundo posicionamento, a hidrovia deve ser licenciada e deve ser realizada avaliação de viabilidade para a implantação de novas hidrovias e as hidrovias existentes devem passar por um processo de regularização, com emissão de Licença de Operação LO, condicionada a elaboração de um estudo ambiental, não necessariamente EIA/RIMA. Nessa LO deverão estar incluídas as intervenções rotineiras necessárias à segurança da navegação (dragagens de manutenção, serviços de manutenção da sinalização, etc.), não necessitando serem conduzidos através de licenciamentos separados. 
Em relação ao assunto, Brandt (2003) emitiu parecer em que apresenta argumentos que se aproximam mais do primeiro posicionamento do órgão ambiental supracitado. Ao iniciar a abordagem do tema o autor apresenta a seguinte afirmação.

\begin{abstract}
O uso dos rios para a navegação é livre. São públicas e de uso comum as águas navegáveis (Art. 2º, Decreto 24.643 de 10/07/34), são bens públicos de uso comum os rios (Art. 99 - Lei 10.406 de 10/01/02) e independe de concessão, permissão, ou autorização o transporte de cargas e de concessão ou permissão o transporte de pessoas pelos meios rodoviário e aquaviário (Art. 2 - Lei 9.074, de 07/07/95) (BRANDT, 2003).
\end{abstract}

Quando na análise específica do licenciamento de hidrovias ou licenciamento de obras hidroviárias, o autor ressalta que são sujeitas ao Estudo Prévio de Impacto Ambiental as obras ou atividades potencialmente causadoras de significativa degradação do meio ambiente (art. 225 da CF) ou ainda, os estabelecimentos e atividades utilizadoras de recursos ambientais, consideradas efetiva ou potencialmente poluidoras ou capazes de causar degradação ambiental, as quais estão sujeitas ao licenciamento ambiental (art. 10 da lei 6.938, de 31/08/81 e art. 2 da resolução CONAMA 237, de 19/12/97) (BRANDT, 2003).

Dessa forma, Brandt (2003) afirma que "a hidrovia em si, que é um rio navegável, não causa poluição, degradação ou impacto ambiental, por ser um recurso ambiental (conforme define a lei 7.804/89), sendo o ambiente no qual a navegação se faz, mas não a atividade de navegação". O autor ainda faz uma analogia, explicando que "a hidrovia está para a navegação da mesma forma que a mata está para a atividade madeireira, o solo para a agricultura ou a jazida para a mineração. Neste caso, não há o que licenciar, pois o rio não é uma obra, nem um estabelecimento, nem uma atividade".

No mesmo sentido se posiciona Milaré (2004). O autor afirma que "a hidrovia sujeita ao licenciamento só pode ser aquela decorrente de obra civil". Ainda segundo o autor, todos os elementos estruturais complementares a ela, como portos, terminais, rodovias e ferrovias submetem-se a licenciamento próprio, sem prejuízo da avaliação ambiental da hidrovia, enquanto via de navegação de integração regional ou transnacional.

Sobre obras de melhoria das condições do canal de navegação, Brandt (2003) afirma que as obras de melhoria das condições de navegação, por atuarem diretamente no leito dos rios, têm potencial poluidor ou degradador, portanto submetem-se ao licenciamento ambiental. Dentre estas obras, cita o autor: 
derrocamentos, dragagens de leitos já consolidados (o que é diferente da dragagem para desassoreamento de canal, onde o material não é consolidado), abertura de canais artificiais. Em consonância com esta análise, ele apresenta as obras sujeitas ao licenciamento ambiental listadas no anexo I da Resolução CONAMA 237/97, tais como: retificação de curso de água; abertura de barras, embocaduras e canais, e; dragagem e derrocamentos em corpos d'água.

Segundo o autor a indicação de hidrovia dentre as obras civis a serem licenciadas é uma falha, na medida em que a hidrovia é um recurso ambiental e as obras relacionadas às hidrovias já estão devidamente listadas no anexo I da Resolução CONAMA 237/97 (BRANDT, 2003).

Milaré (2004) não vê essa falha. Para este autor, a previsão de licenciamento ambiental de hidrovias na Resolução CONAMA $237 / 97$ só pode ser entendida em relação a obras de engenharia, que the aumentem ou aperfeiçoem a utilidade ou propiciem a navegação em trecho de corrente antes não navegável em si mesmo ou à melhoria das condições já existentes.

Essa análise é mais coerente considerando que a expressão hidrovia no anexo da resolução está incluída no item "obras civis". As hidrovias, ou intervenções hidroviárias, consideradas obras civis devem ser submetidas ao processo de licenciamento. Quando não configurada como obras civis, ou seja, o próprio curso d'água utilizado pela navegação, não há o que se falar em licenciamento.

É preciso considerar também a situação institucional no Brasil, pois não convém fazer uma análise descolada da realidade das instituições brasileiras. Cabe reconhecer a complexidade institucional, em que o gerenciamento das atividades na bacia hidrográfica conta com diversos atores. No cenário atual, vários órgãos têm papéis diferenciados na bacia, tais como: órgãos responsáveis pela infraestrutura hidroviária; órgãos responsáveis pela regulação; órgãos responsáveis pela segurança da navegação; operadores de navegação; terminais públicos ou privados; empreendedores privados que fazem dragagem nos rios para finalidades distintas, como extração de areia para uso na construção civil e dragagens sanitárias; comitês de bacia; órgãos ambientais e órgãos responsáveis pela gestão de recursos hídricos. Em resumo, trata-se de um arranjo institucional complexo.

Nessa conjuntura, considerando o arcabouço legal e institucional brasileiros, não seria adequado considerar todos os atributos do transporte hidroviário interior, trechos navegáveis, intervenções necessárias e a navegação como apenas um 
empreendimento para fins de licenciamento, que por suas características deve ter um empreendedor definido.

Para qualquer ação governamental deve haver uma análise integrada em todos os aspectos, econômico, social e ambiental. A análise conjunta e de suas inter-relações deve fomentar o próprio planejamento. Isso não pode ser confundido com o processo de licenciamento e sim fazer parte do planejamento, da tomada de decisão e da execução de toda política, plano ou projeto. Especificamente em termos de licenciamento, não deve existir confusão entre analisar as inter-relações entre empreendimentos e seus impactos e considerar todas as variáveis como um único objeto de licenciamento. Isso se torna ainda mais claro, e pode criar um conflito ainda maior, quando as responsabilidades dos órgãos ou entidades governamentais são definidas por lei. Nesse caso, não cabe ao órgão licenciador redefinir as competências dos órgãos e entidades governamentais que atuam como empreendedores.

Identifica-se neste ponto um problema, mas também uma possível solução. Um trabalho conjunto entre os atores envolvidos poderia trazer resultados satisfatórios. Além disso, pode-se buscar um rearranjo institucional. Uma medida seria a definição clara de responsabilidades, ou em termos mais extremos, criar um gestor da hidrovia com capacidade de execução, regulação e poderes definidos sobre todos os usos que podem afetar o curso d'água e consequentemente a navegabilidade.

Outra medida, já detalhada anteriormente, é melhorar o processo de planejamento e buscar com que haja participação mais efetiva dos atores. Além dessas ações e da atribuição adequada das responsabilidades é necessário que haja um claro delineamento do procedimento de licenciamento ambiental, que se inicia pela definição do objeto.

Verifica-se, portanto, que não há um posicionamento unânime sobre o objeto de licenciamento. No entanto, com base no exposto, entende-se que:

- As hidrovias são licenciáveis quando configuradas como obras civis;

- As obras ou intervenções para o transporte hidroviário interior devem ser licenciadas;

- Para a definição do procedimento de licenciamento devem-se considerar os impactos da intervenção e as condições ambientais do local; 
- É adequado, mas não obrigatório, que para o processo de licenciamento seja considerado o conjunto de intervenções.

\subsubsection{Procedimento de Licenciamento Ambiental}

Definido o objeto do licenciamento, é necessário avaliar como as obras e atividades hidroviárias devem ser tratadas no âmbito do processo de licenciamento. Esta seção tem como objetivo analisar os principais pontos de questionamentos do processo de licenciamento ambiental e sugerir uma abordagem para esse procedimento.

O processo de licenciamento deve ser compatível com as etapas de planejamento e implantação das atividades modificadoras do meio ambiente, tendo por base a natureza, o porte e as peculiaridades de cada atividade. Ou seja, a definição do processo de licenciamento deve considerar e ponderar os riscos que 0 projeto oferece ao meio ambiente. Nesse sentido, o artigo 4ํ da Resolução Conama 01/86 apresenta a seguinte redação.

Art. 4 - Os órgãos ambientais competentes e os órgãos setoriais do SISNAMA deverão compatibilizar os processos de licenciamento com as etapas de planejamento e implantação das atividades modificadoras do meio Ambiente, respeitados os critérios e diretrizes estabelecidos por esta Resolução e tendo por base a natureza o porte e as peculiaridades de cada atividade.

De forma análoga a Resolução Conama 237/97 dispõe sobre os procedimentos específicos para as licenças ambientais.

Art. 12 - O órgão ambiental competente definirá, se necessário, procedimentos específicos para as licenças ambientais, observadas a natureza, características e peculiaridades da atividade ou empreendimento e, ainda, a compatibilização do processo de licenciamento com as etapas de planejamento, implantação e operação.

$\S 1$ - Poderão ser estabelecidos procedimentos simplificados para as atividades e empreendimentos de pequeno potencial de impacto ambiental, que deverão ser aprovados pelos respectivos Conselhos de Meio Ambiente.

$\S 2^{\circ}$ - Poderá ser admitido um único processo de licenciamento ambiental para pequenos empreendimentos e atividades similares e vizinhos ou para aqueles integrantes de planos de desenvolvimento aprovados, previamente, pelo órgão governamental competente, desde que definida a responsabilidade legal pelo conjunto de empreendimentos ou atividades.

É nesse sentido, e com base no contexto apresentado ao logo deste trabalho, que esta pesquisa busca, além de clarificar algumas questões ambientais, 
apresentar propostas metodológicas para o processo de licenciamento ambiental de atividades e empreendimentos hidroviários.

Uma questão sempre debatida é a relação entre as fases do projeto e aquelas do licenciamento. Em alguns momentos, se observa a tentativa de correlacionar as fases das atividades e empreendimentos hidroviários com as fases descritas no processo de licenciamento ordinário. No entanto, o processo de licenciamento não deve ser um procedimento rígido e precisa considerar as peculiaridades de cada projeto.

O licenciamento ambiental no País iniciou-se há aproximadamente três décadas com um delineamento baseado em atividades industriais, que apresentam explicitamente uma fase prévia, outra de instalação e a de operação. Com o tempo verificou-se que este processo não é o mais adequado para todas as tipologias, entre as quais se encontram os projetos hidroviários. Nessa linha, os procedimentos de licenciamento ambiental específicos de vários tipos de empreendimentos vêm sendo detalhados por meio de Resoluções do CONAMA, Portarias Interministeriais ou do Ministério do Meio Ambiente, em busca de adequar o processo de licenciamento às fases e características da tipologia. No entanto, não há nenhuma norma que trata do processo de licenciamento de atividades e empreendimentos hidroviários.

Não se entrará na questão jurídica, se o processo normativo utilizado é o mais adequado ou quais devem ser os instrumentos legais para fazer a adequação do licenciamento ambiental de projetos hidroviários. O que se busca é analisar formas alternativas de como podem ser os procedimentos, consideradas as particularidades dessa tipologia.

Além da fase prévia, em que se avalia a concepção do projeto, a legislação ambiental em geral reconhece mais duas etapas, a implantação e a operação. A tentativa de enquadrar todos os projetos hidroviários nessa estrutura tem causado algumas confusões. Muitas vezes tenta-se, de forma equivocada, correlacionar a etapa de implantação com a execução da intervenção e a etapa de operação com a navegação. Essa relação, execução da intervenção/navegação com implantação/operação da hidrovia, não faz sentido na maioria das atividades ou empreendimentos hidroviários.

Como exemplo, pode-se citar as atividades de dragagem. Não há pertinência em falar de implantação e operação de uma dragagem. A dragagem se constitui 
somente como uma atividade, com suas diversas etapas de execução, antes, durante e após a dragagem. Na prática, já prevalece esse entendimento de que o licenciamento ambiental de dragagens deve, no mínimo, prescindir das licenças prévia e de instalação.

Deve ficar claro que na maioria das vezes não é possível fazer a correlação da execução da intervenção com implantação da hidrovia e da navegação com operação. As intervenções devem ser realizadas de acordo com a necessidade do local e momento, buscando-se avaliar os impactos da intervenção e as alternativas existentes para se alcançar o mesmo objetivo.

Por seu turno, a navegação é muitas vezes confundida com a operação da hidrovia. Cabe ressaltar que de forma geral o transporte hidroviário não é licenciável. Conforme previsto no anexo da Resolução Conama 237/97, deve ser licenciado o transporte de cargas perigosas. Convém ainda citar que, conforme legislação brasileira atual, independe de concessão, permissão, ou autorização o transporte de cargas e de concessão ou permissão o transporte de pessoas pelos meios rodoviário e aquaviário.

De acordo com o artigo 10 da Lei n 6.938, de 31 de agosto de 1981, a construção, instalação, ampliação e funcionamento de estabelecimentos e atividades utilizadores de recursos ambientais, efetiva ou potencialmente poluidores ou capazes, sob qualquer forma, de causar degradação ambiental dependerão de prévio licenciamento ambiental. Portanto, fica claro que o objeto de licenciamento é um projeto, empreendimento ou atividade. Isso não impede, mas também não torna obrigatório, que o empreendedor opte por realizar o licenciamento conjunto de um grupo de empreendimentos ou atividades sob sua responsabilidade. $\mathrm{O}$ tratamento conjunto de projetos de empreendedores diferentes se mostra ainda mais complexo.

Em termos ambientais, muitas vezes a análise conjunta pode ser mais efetiva. Pelo lado do empreendedor, isso se mostra vantajoso em alguns casos. A opção de tratar os empreendimentos conjuntamente está prevista também no artigo 12 da Resolução Conama no 237/97, conforme se observa nos trecho a seguir.

Art. 12 - O órgão ambiental competente definirá, se necessário, procedimentos específicos para as licenças ambientais, observadas a natureza, características e peculiaridades da atividade ou empreendimento e, ainda, a compatibilização do processo de licenciamento com as etapas de planejamento, implantação e operação.

$(\ldots)$ 
$\S 2^{0}$ - Poderá ser admitido um único processo de licenciamento ambiental para pequenos empreendimentos e atividades similares e vizinhos ou para aqueles integrantes de planos de desenvolvimento aprovados, previamente, pelo órgão governamental competente, desde que definida a responsabilidade legal pelo conjunto de empreendimentos ou atividades.

Além dos casos em que a análise conjunta é adequada, mas facultativa ao empreendedor, tem-se também que as situações em que a análise conjunta poderia ser obrigatória. Este é o caso de projetos de melhoramentos na via navegável com a intenção de mudança de classe e, que para cumprir esse propósito, sejam necessárias outras intervenções. Nessa situação o licenciamento ambiental do conjunto de intervenções não é somente desejável, como deveria ser obrigatório, já que cada intervenção de forma isolada não cumpre seu objetivo e consequentemente outras serão necessárias.

\subsubsection{Proposta para o Licenciamento Ambiental de AEH}

Destaca-se que esta pesquisa tem como ponto focal a infraestrutura hidroviária. Na infraestrutura hidroviária, a ênfase se dará na via navegável, pois os procedimentos para os terminais e as estruturas associadas aos mesmos são conhecidos.

Nesta pesquisa, as intervenções relacionadas à infraestrutura hidroviária serão divididas em três tipos, além da "implantação de canais". Os três tipos de intervenções são: "intervenções de implantação", "intervenções de melhoramento" e "intervenções de manutenção". Empregado aqui por representar melhor os projetos em questão, o termo intervenção não é aplicado na legislação ambiental, que utiliza apenas as expressões empreendimentos ou atividades. Não há uma relação clara entre essas expressões e aquele termo.

Para esta proposta, serão abordados as atividades e empreendimentos relacionados à infraestrutura hidroviária, considerados: "implantação de canais", "intervenções de implantação", "intervenções de melhoramento" e "intervenções de manutenção".

A "implantação de canais" tem o objetivo criar canais de navegação onde não há curso d'água preexistente ou os cursos d'água existentes não possibilitam nenhum tipo de navegação, com os impactos de uma implantação se assemelhando ao primeiro caso. Os canais artificiais podem ser construídos com o início e fim na 
mesma bacia ou para transposição de bacias, sendo o último mais utilizado. Esse tipo de empreendimento apresenta grande complexidade ambiental.

As "intervenções" são obras ou serviços de engenharia necessários a incrementar ou auferir condições de navegabilidade em um curso d'água.

As "intervenções de implantação" são aquelas realizadas pela primeira vez no corpo hídrico em que não há navegação. Em seu turno, as "intervenções de melhoramento" e "manutenção" ocorrem somente em corpos d'água em que existe navegação.

As "intervenções de melhoramento" são aquelas que buscam melhorar a condição de navegabilidade em um curso d'água. Este grupo de intervenções é o mais amplo, pois incluem todas as intervenções não enquadradas nos demais grupos. Essas intervenções podem ter como objetivo a mudança de classe da hidrovia ou não. Diferem-se das "intervenções de manutenção", principalmente, por não se configurarem como atividades rotineiras. Por outro lado, diferenciam-se das "intervenções de implantação" por estarem em cursos d'água em que existe navegação.

As "intervenções de manutenção", mais corretamente denominadas atividades rotineiras de manutenção, são aquelas destinadas a manter as condições estabelecidas nas intervenções de implantação e de melhoria ou das condições naturais do corpo hídrico.

Com base nessa classificação, é possível realizar uma proposta preliminar para a classificação das atividades e empreendimentos hidroviários e para 0 licenciamento ambiental desses projetos, que é representada no fluxograma apresentado na Figura 9.2.

Buscou-se, no fluxograma, fazer propostas de possíveis procedimentos de licenciamento para cada uma das situações. No entanto, cabe ressalvar que essas são propostas genéricas e casos específicos podem merecer tratamentos diferenciados, de acordo com as condições locais. Convém ressaltar, também, conforme já apresentado, que o que deve ser licenciado são as obras civis, ou seja, as intervenções ou a implantação do canal.

Para a definição dos estudos, deve se levar em conta o porte da intervenção e as condições ambientais. Nesse sentido, sugere-se que sejam desenvolvidas pesquisas para definição mais aprofundada de procedimentos e estudos no licenciamento ambiental, com base no porte e nas características ambientais. 


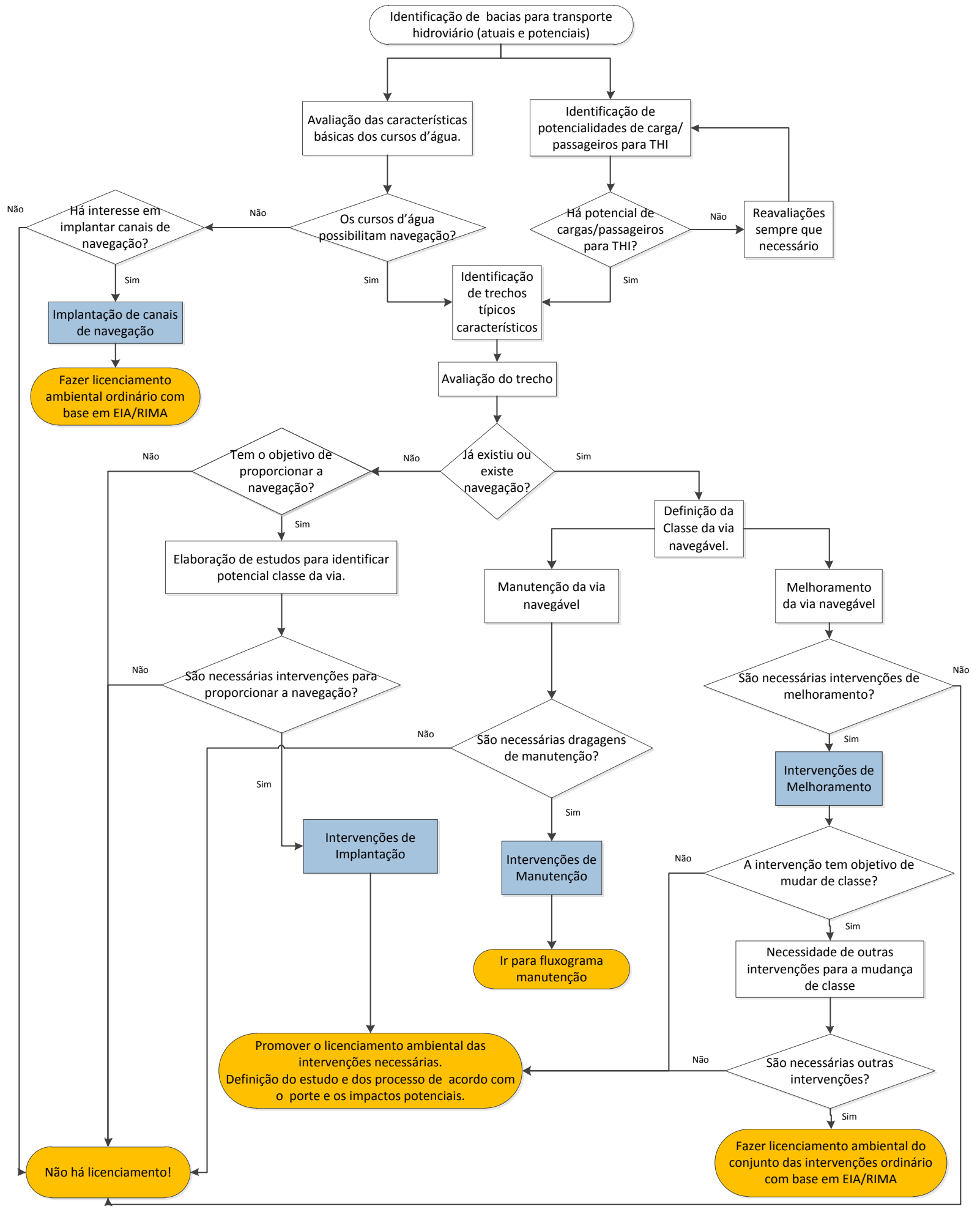

Figura 9.2 - Fluxograma representativo da proposta metodológica para a definição do procedimento de licenciamento ambiental de projetos hidroviários. 
Inicialmente, é necessário identificar a tipologia de atividade ou empreendimento hidroviário de que se está tratando. Para tanto, a partir da avaliação das características do curso d'água, identifica-se a possibilidade de navegação ou não. Caso não exista curso d'água ou não haja possibilidade de navegação, em havendo 0 interesse em se promover 0 transporte hidroviário interior, a única alternativa é a implantação de canal de navegação.

Caso exista um curso d'água e este ofereça potencial para navegação e por outro lado exista potencialidade de carga ou passageiro que justifique 0 desenvolvimento do THI, passa-se à identificação de trechos típicos característicos. O que é denominado de trechos típicos característicos são trechos que apresentam condições do curso d'água e de navegação semelhantes. Trechos com condições para a navegação diferenciadas não deveriam ser considerados conjuntamente, a menos em alguns casos que assim se mostre mais adequado. Cada trecho pode apresentar necessidades de intervenções diferenciadas.

Após a identificação do trecho de interesse, avalia-se se nele existe ou já existiu navegação. Caso a resposta seja negativa, mas há o objetivo de proporcionar a navegação e, além disso, são necessárias intervenções para propiciar a navegação, essas serão Intervenções de Implantação.

Por outro lado, caso no trecho de interesse, existe ou existiu navegação, pode-se promover Intervenções de Manutenção ou Intervenções de Melhoramento, de acordo com o objetivo que se deseje alcançar, quais sejam: apenas manter as condições de navegabilidade da via ou realizar melhorias, sendo que essas podem gerar mudanças de classes ou não.

As Intervenções de Manutenção que necessitam de licenciamento ambiental são, basicamente, as dragagens de manutenção. Para essas atividades, utilizou-se como proposta inicial uma representação do tratamento ambiental com base nos procedimentos já utilizados pelo órgão ambiental federal, que faz uso de emissão de uma Licença de Operação - LO, e na norma de gerenciamento do material a ser dragado (Resolução CONAMA oㅜ 454/2012). Esse procedimento é representado no fluxograma da Figura 9.3. 


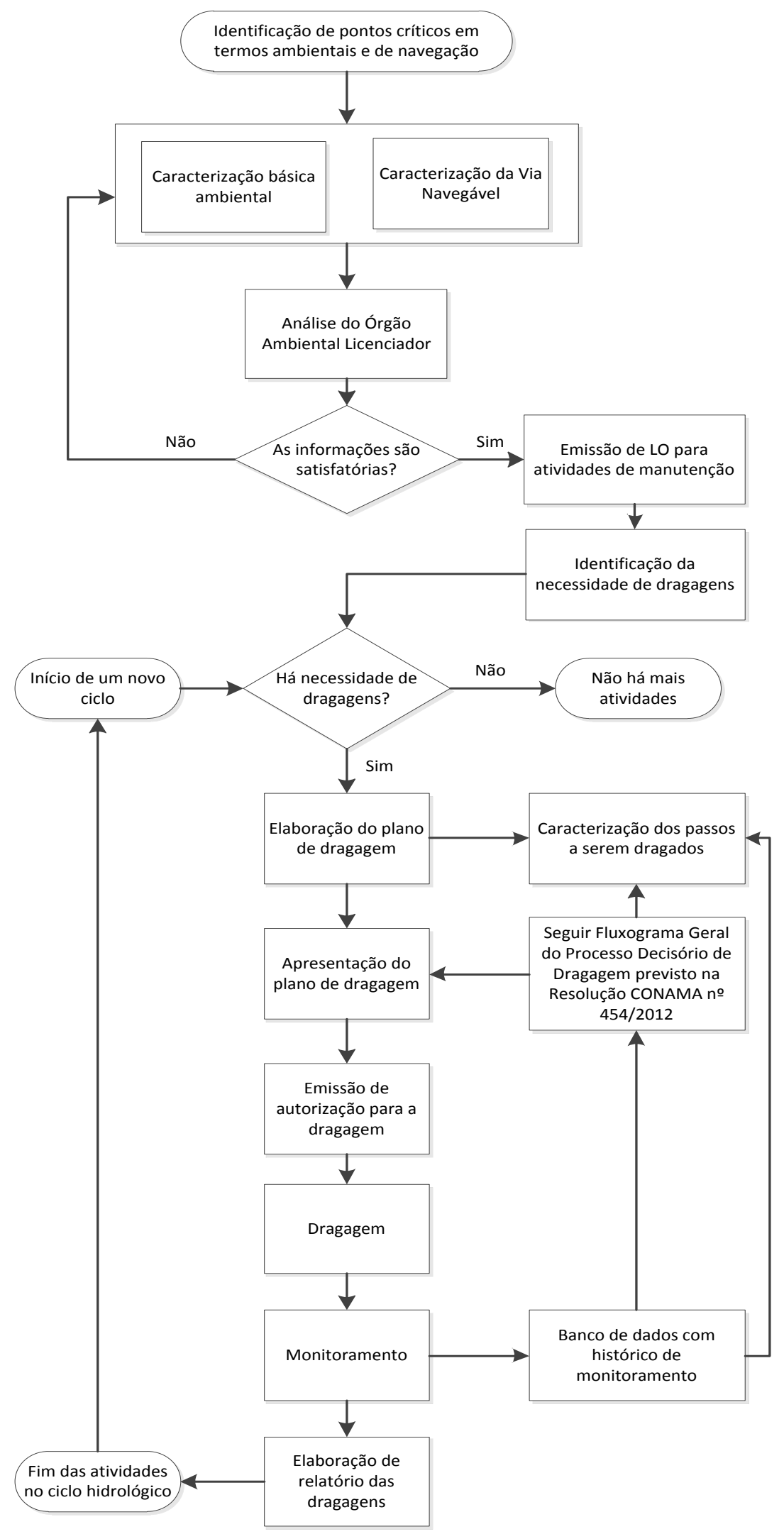

Figura 9.3 - Fluxograma representativo da proposta inicial de tratamento ambiental para atividades de manutenção. 
Pode-se observar que o procedimento apresentado é complexo e moroso, não sendo coerente com as Intervenções de Manutenção que são atividades simples. As dragagens de manutenção são atividades realizadas em sedimentos que naturalmente seriam transportados pela própria dinâmica fluvial dos rios. Ressalta-se que essas atividades objetivam apenas manter as condições estabelecidas ou naturais do curso d'água, ou seja, manter a navegabilidade com segurança.

Além disso, em sendo os cursos d'água sistemas dinâmicos, pode haver certa imprevisibilidade em relação às dragagens de manutenção. Ademais, é curto o período entre a identificação da necessidade de dragagem e o prazo final em que a dragagem deve ser feita. Portanto, um procedimento para avaliação dessa atividades deve apresentar celeridade, o que não se observa no procedimento representado na Figura 9.3. Dessa forma, verifica-se a necessidade de simplificação.

Pode-se identificar que uma das principais dificuldades geradas pelo procedimento supracitado reside na necessidade de dois momentos de "autorização" do órgão ambiental: emissão de LO e autorização após o plano de dragagem. Nesse sentido, como uma forma de simplificar, propõe-se que as intervenções sigam um procedimento que necessite apenas da emissão de licença de operação ou de autorização.

A primeira alternativa consiste na obtenção de uma licença de operação para as atividades de manutenção para um trecho típico característico. Após a emissão da licença de operação ficariam autorizadas todas as Intervenções de Manutenção nesse trecho. Nesse caso, não haveria necessidade de autorização específica para essas atividades. $O$ empreendedor deveria apenas comunicar o órgão ambiental previamente às dragagens, apresentando o plano de dragagem. Após o final das atividades, o empreendedor apresentaria o relatório de monitoramento. Esse procedimento está representado na Figura 9.4.

Outra alternativa consiste na obtenção de uma autorização específica para uma determinada atividade de manutenção. Neste caso, seria necessário encaminhar ao órgão ambiental o plano de dragagem e a caracterização para análise e emissão de autorização, conforme representado na Figura 9.5. Esse tipo de procedimento poderia ser adotado nos trechos para os quais não há licença de operação para manutenção. 


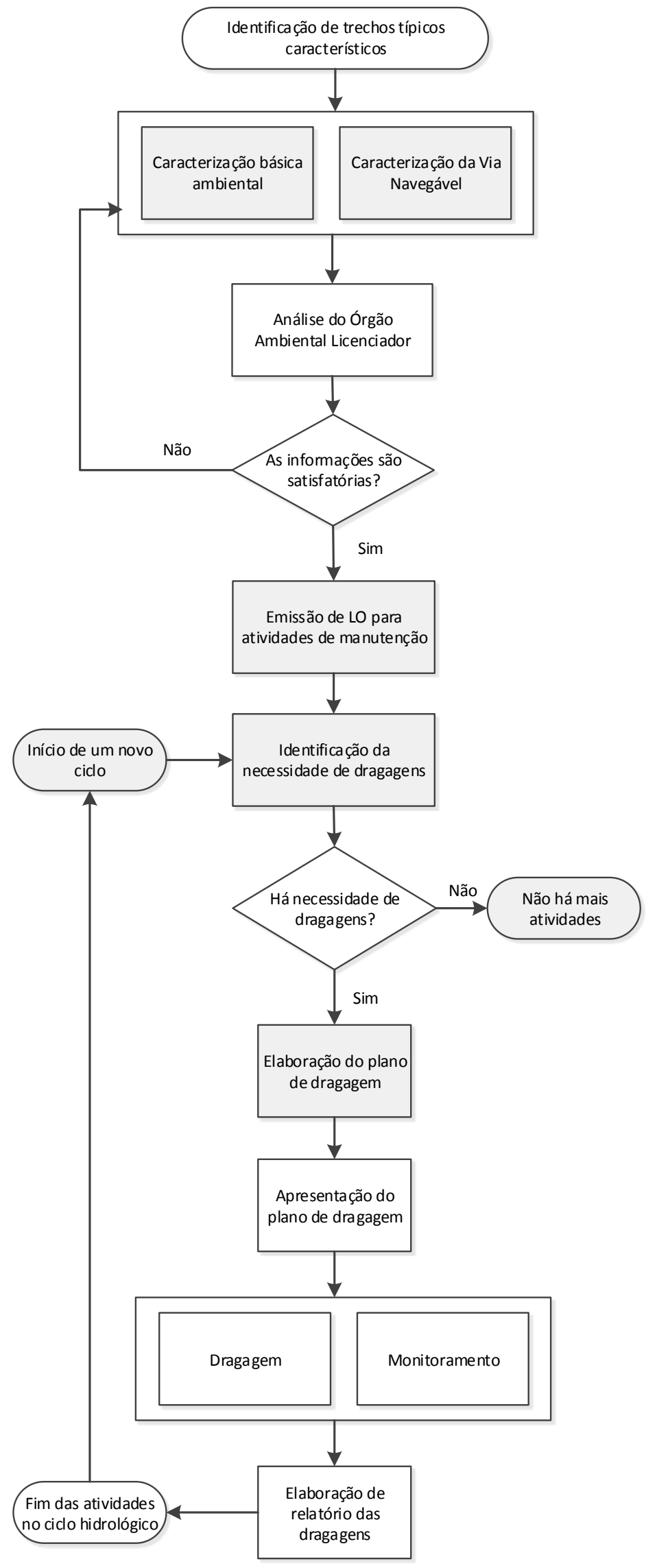

Figura 9.4 - Fluxograma representativo da proposta de tratamento ambiental para atividades de manutenção, considerando a emissão de licença de operação. 


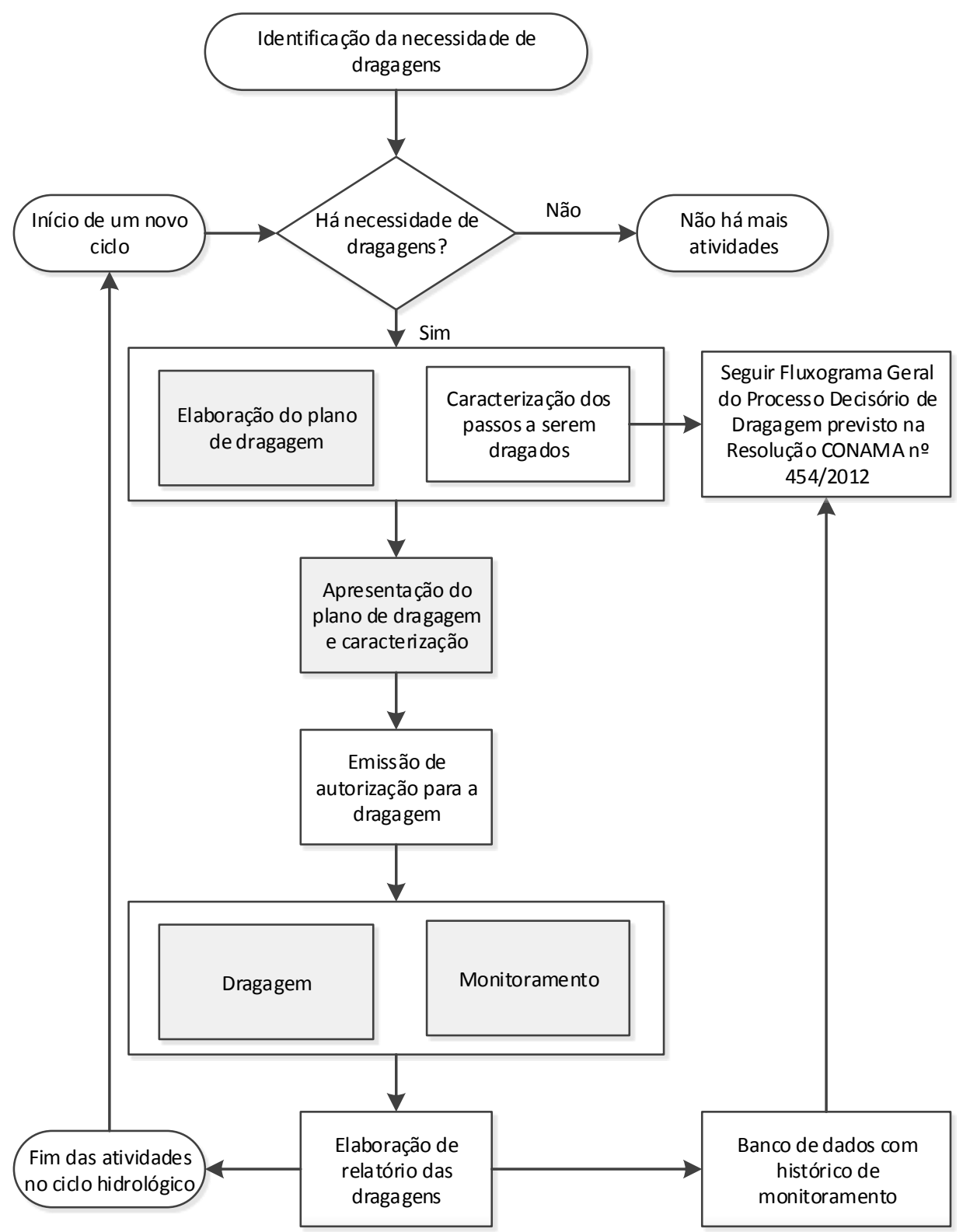

Figura 9.5 - Fluxograma representativo da proposta de tratamento ambiental para atividades de manutenção, considerando a emissão de autorização.

\subsubsection{Consulta aos Especialistas}

Por se tratar de pesquisa cuja essência é a formulação de uma abordagem metodológica para auxiliar no tratamento ambiental de projetos da tipologia hidroviária, a formulação e a verificação das possíveis abordagens englobam não só a análise da experiência encontradas em literatura, outras referências, documentos técnicos e casos de estudo, mas também a discussão com especialistas e gestores de meio ambiente e do setor hidroviário para permitir a construção de uma representação conceitual sobre a questão. 
Dessa forma, as proposições desenvolvidas devem ser, de algum modo, avaliadas e verificadas. No presente trabalho, essa verificação foi realizada pela submissão das abordagens propostas a um painel de especialistas e pelo teste da abordagem em casos hipotéticos de atividades e empreendimentos hidroviários.

Para a consulta aos especialistas foi elaborado o documento de consulta, apresentado no Apêndice $B$, contendo as propostas até então desenvolvidas para 0 planejamento do setor hidroviário e para o licenciamento ambiental de intervenções hidroviárias.

O documento de consulta foi enviado por correspondência eletrônica a um painel de 16 especialistas. Os especialistas consultados são profissionais de entidades públicas e privadas, órgãos ambientais, empreendedores, consultores, especialistas da área de planejamento ambiental e acadêmicos.

Os comentários e sugestões foram enviados pelos especialistas também por correspondência eletrônica. Foi realizado ainda um encontro, em que foram discutidos alguns pontos das propostas, na sala de aula do Programa de Pós Graduação em Tecnologia Ambiental e Recursos Hídricos da Universidade de Brasília - PTARH/UnB.

Após o recebimento das contribuições e do evento, as sugestões gerais pertinentes foram incorporadas a presente dissertação e as sugestões quanto aos procedimentos, que eram o principal foco da consulta, suscitaram modificações nos fluxogramas.

No fluxograma de planejamento de planejamento, foi sugerido que a identificação de planos estratégicos regionais e setoriais fosse realizada em paralelo com a identificação das características do transporte hidroviário, a delimitação dos espaços protegidos e a identificação das características e necessidades socioambientais. No fluxograma de licenciamento foi proposta a mudança do procedimento de licenciamento do conjunto de intervenções em situações de melhorias com mudança de classe. As representações dos procedimentos propostos com as modificações após as consultas são apresentados na Figura 9.6 e na Figura 9.7. 


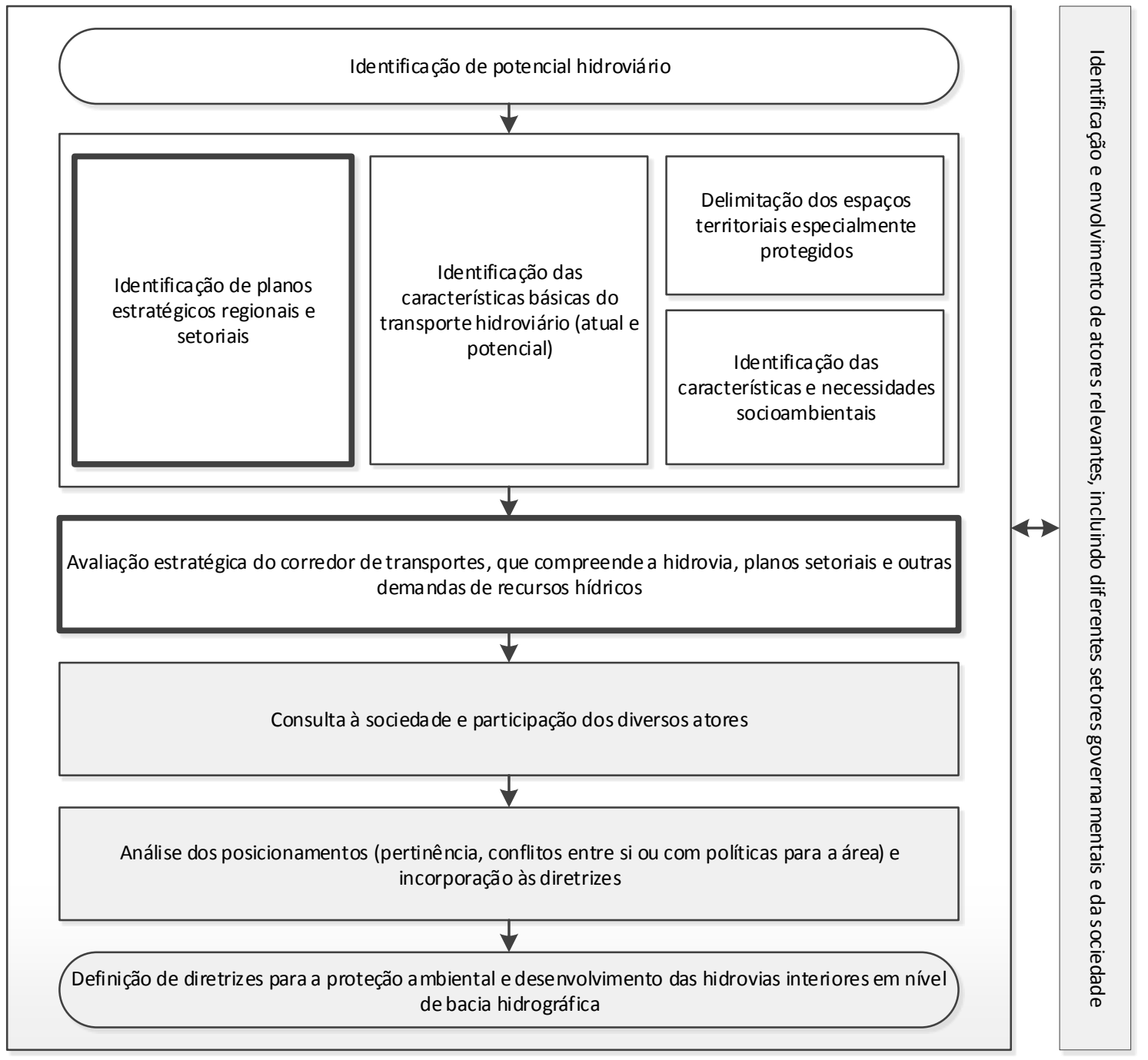

Figura 9.6 - Abordagem para o planejamento no setor de transporte hidroviário interior após consulta aos especialistas. 


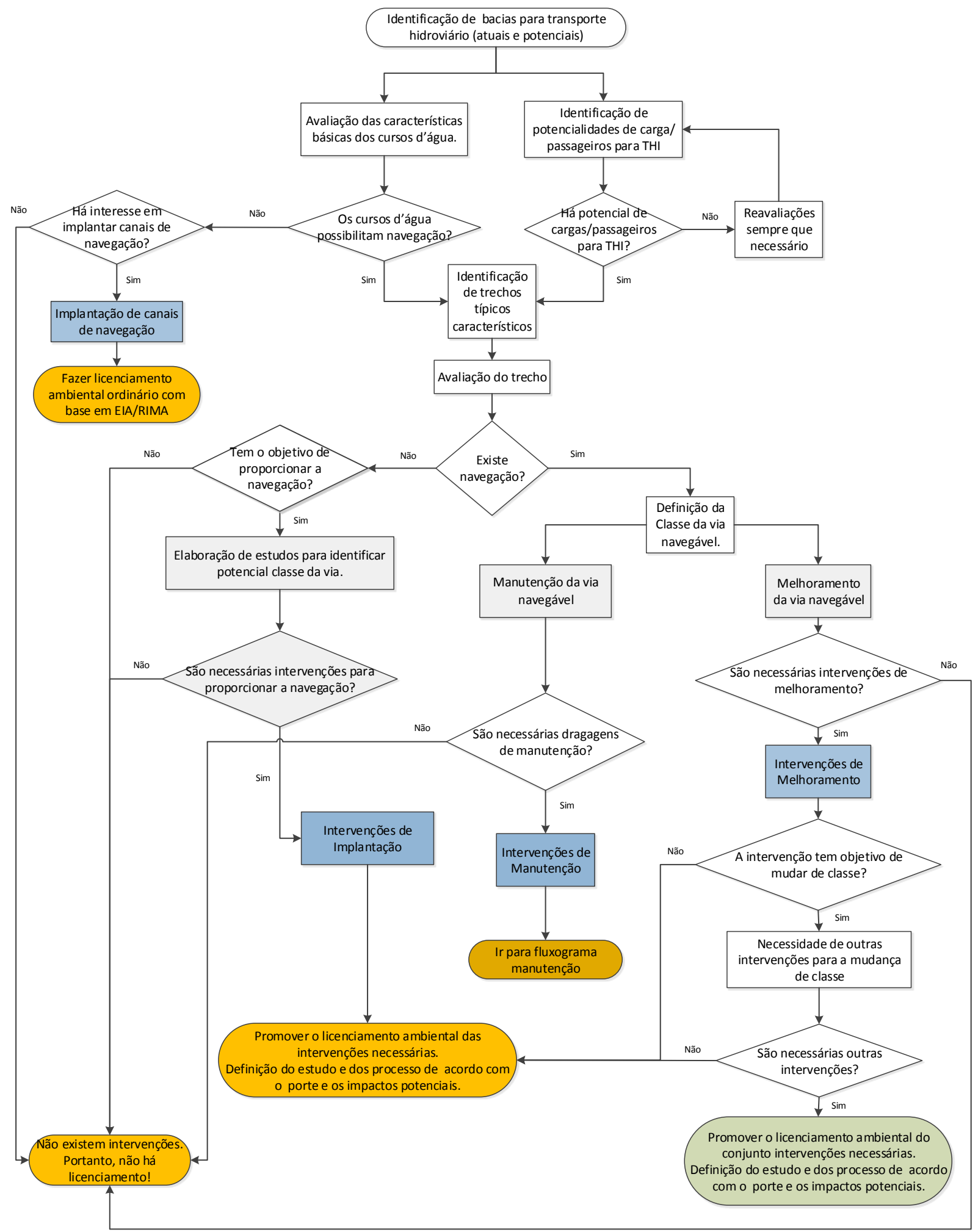

Figura 9.7 - Fluxograma representativo da proposta metodológica para a definição do procedimento de licenciamento ambiental de projetos hidroviários após consulta aos especialistas. 


\subsubsection{Aplicação da metodologia}

Para tornar mais claro e facilitar o entendimento da proposta deste trabalho, optou-se realizar a aplicação da metodologia para exemplificar a tipificação de empreendimentos e intervenções em um caso concreto. Para tanto, parte-se da seguinte situação hipotética ${ }^{13}$.

O objeto de análise deste exemplo são trechos de dois rios de um sistema fluvial, o Rio Anchieta e o Rio Pitangui. O Rio Pitangui é navegável em todo o trecho analisado. Por sua vez, o Rio Anchieta é navegável apenas entre os pontos $A$ e $C$, trecho A-C. Esse rio não é navegável a montante do Ponto $A$ e a jusante do Ponto C.

Considerar-se-á que existem apenas duas classes de hidrovias, Classe $1 \mathrm{e}$ Classe 2. As características de cada classe não são relevantes para aplicação neste exercício. É importante saber apenas que a Classe 1 é superior à Classe 2.

Com as classes hidroviárias definidas, enquadram-se os trechos navegáveis nas devidas classes, considerando as características de cada trecho. As vias navegáveis em estudo foram classificadas da forma apresentada no Quadro $9.1 \mathrm{e}$ ilustrada na Figura 9.8. Todo o trecho navegável do Rio Pitangui tem características homogêneas, classificado como Classe $2 \mathrm{em}$ toda a sua extensão. $O$ trecho navegável do Rio Anchieta (Trecho $A-C$ ) apresenta dois trechos com características homogêneas, que serão denominados de trecho $A-B$ e trecho $B-C$. O trecho $A-B$ foi classificado como Classe 2 e o trecho B-C foi classificado como Classe 1.

Quadro 9.1 - Situação da navegação e classificação dos trechos analisados nos rios Pitangui e Anchieta.

\begin{tabular}{|c|c|c|c|}
\hline Rio & Trecho & $\begin{array}{c}\text { Situação da } \\
\text { navegação }\end{array}$ & Classe \\
\hline Rio Pitangui & Trecho único & Navegável & Classe 2 \\
\hline \multirow{3}{*}{ Rio Anchieta } & Montante de A & Não navegável & Não aplicável \\
\cline { 2 - 4 } & A-B & Navegável & Classe 2 \\
\cline { 2 - 4 } & B-C & Navegável & Classe 1 \\
\cline { 2 - 4 } & Jusante de C & Não navegável & Não aplicável \\
\hline
\end{tabular}

\footnotetext{
${ }^{13}$ Os dados hipotéticos são utilizados com o objetivo didático de conseguir expressar de forma clara a aplicação de diferentes situações da proposta. Além de não haver um caso real que contemple todas as situações descritas no presente trabalho, uma situação real mereceria maiores detalhamentos devido a questões já discutidas durante os projetos, ou seria necessário fazer várias simplificações. Essas simplificações levariam a uma situação semelhante a aqui apresentada sem, contudo, abrangência que se consegue com a liberdade dada por uma situação hipotética.
} 


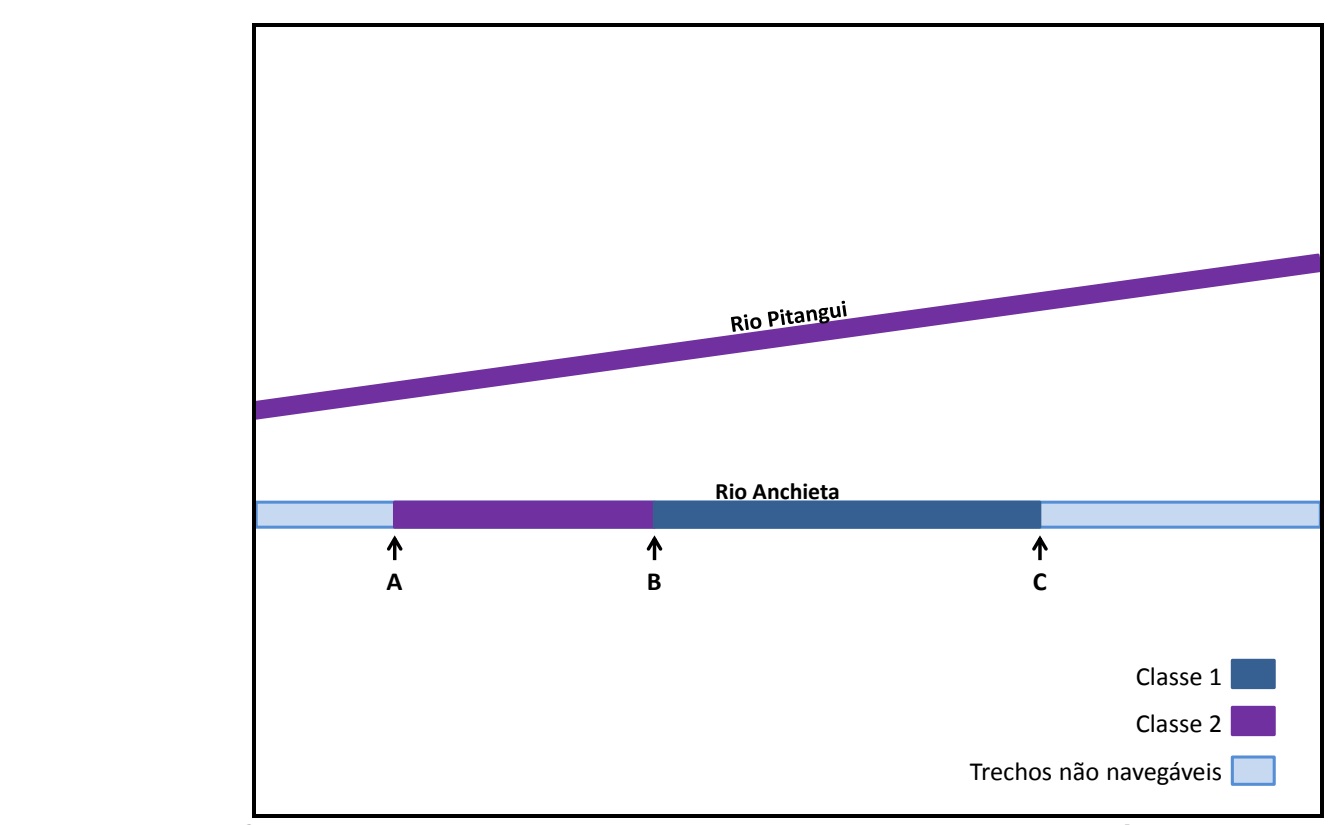

Figura 9.8 - Caracterização e classificação dos trechos navegáveis dos rios Anchieta e Pitangui.

Após a caracterização dos trechos, passa-se à análise de algumas possíveis atividades e empreendimentos.

Inicialmente, far-se-á a análise das atividades que podem ser aplicadas em todos os trechos navegáveis. Em qualquer um dos trechos navegáveis pode haver problemas ocasionados com baixios formados por consequência da variação de vazão devida ao ciclo hidrológico. Nesses casos seria necessário promover dragagens para remoção dos pontos críticos. Essas dragagens, como tem objetivo manter as condições existentes de navegação, são classificadas como intervenções de manutenção. Pode-se ainda entender que em um determinado ponto, poder-seia identificar a necessidade de retificação, dragagens ou derrocamentos a fim de melhorar a segurança da navegação em determinado local sem, no entanto, aumentar a capacidade de transporte da via. Esses procedimentos se enquadrariam como intervenções de melhoramento sem mudança de classe.

Por outro lado, poder-se-ia buscar a transformação do Trecho A-B em Classe 1 (Figura 9.9). Para tanto, seria necessário identificar as atividades necessárias para esse fim. Nesse caso, estaríamos diante de Intervenções de Melhoramento com mudança de Classe. 


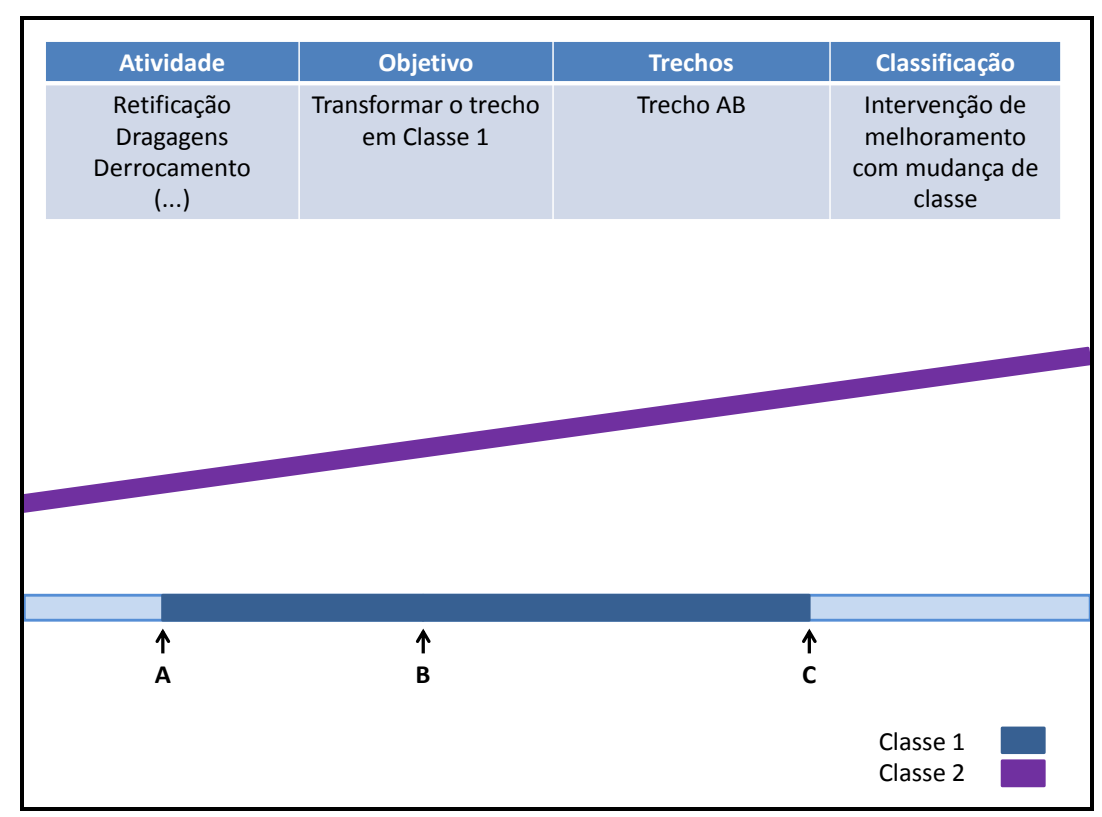

Figura 9.9 - Alteração de classe do Trecho A-B.

Outras atividades poderiam ser realizadas, buscando tornar o trecho navegável no Rio Anchieta se estender até o ponto D, ou seja, tornando o trecho CD navegável. Essa situação está apresentada na Figura 9.10 e estaríamos diante de uma intervenção de implantação.

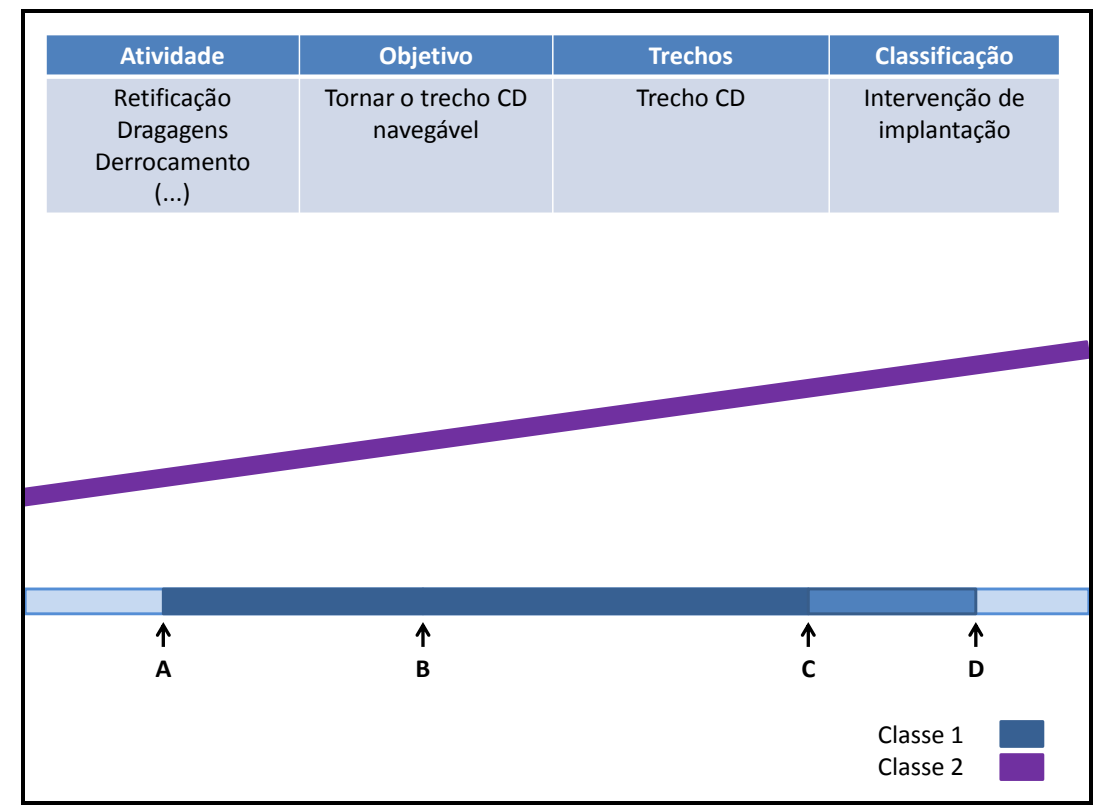

Figura 9.10 - Atividades que buscam transformar o Trecho C-D, em que não há ou teve navegação, em navegável. 
Por fim, caso se buscasse fazer a interligação hidroviária entre os rios Anchieta e Pitangui, a mesma seria feita pela construção de um canal. Nesse caso haveria uma Implantação de Canal. Essa interligação é apresenta na Figura 9.11.

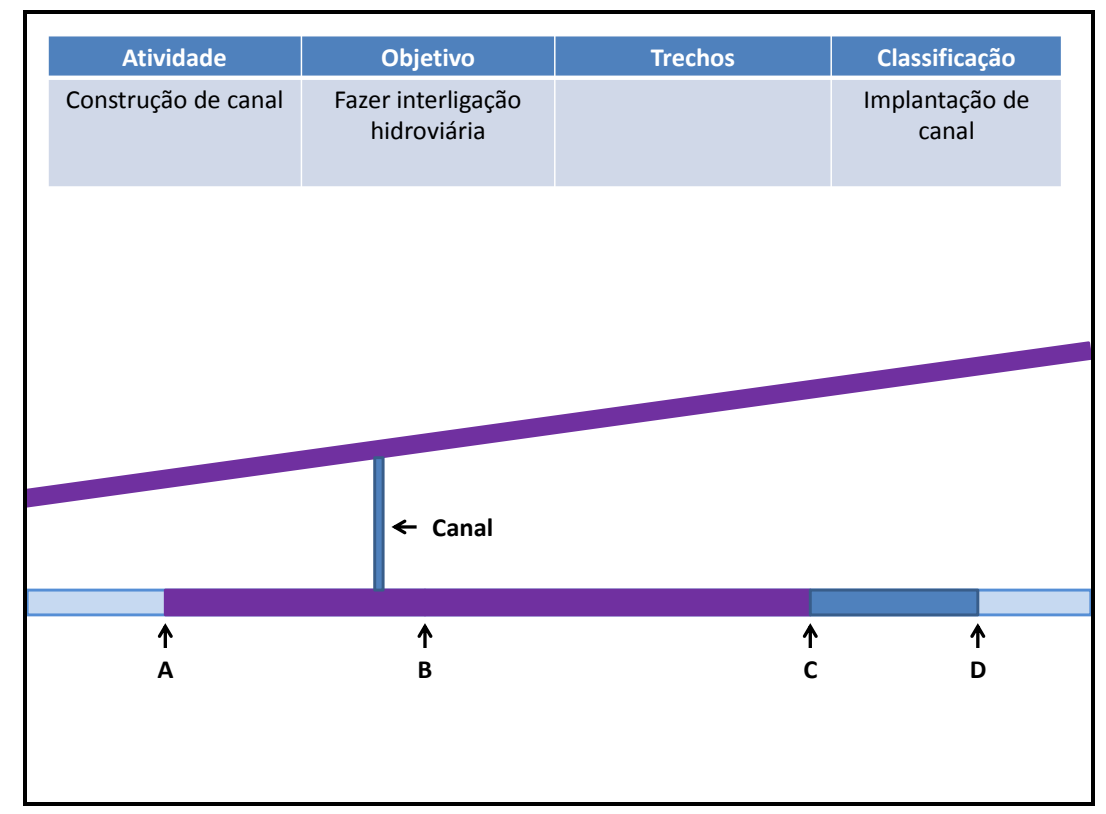

Figura 9.11 - Construção de um canal fazendo a interligação hidroviária entre os rios Anchieta e Pitangui. 
As situações apresentadas neste exemplo são apresentadas de forma sintética no Quadro 9.2.

Quadro 9.2 - Compilação de informações das situações apresentadas na aplicação da metodologia.

\begin{tabular}{|c|c|c|c|c|}
\hline Atividades & Objetivo & Trechos & Classificação & $\begin{array}{l}\text { Procedimento } \\
\text { Licenciamento }\end{array}$ \\
\hline Dragagens & $\begin{array}{lr}\text { Manter } & \text { as } \\
\text { condições } & \\
\text { existentes } & \text { de } \\
\text { navegação } & \text { com } \\
\text { seguranca } & \end{array}$ & $\begin{array}{l}\text { Aplicável } a \\
\text { qualquer trecho } \\
\text { navegável }\end{array}$ & $\begin{array}{l}\text { Intervenção de } \\
\text { Manutenção }\end{array}$ & $\begin{array}{lr}\text { De acordo } & \text { com o } \\
\text { fluxograma } & \text { de } \\
\text { manutenção } & \text { (Figura } \\
9.4 \text { ou } 9.5) & \end{array}$ \\
\hline $\begin{array}{l}\text { Retificação, } \\
\text { Dragagens, } \\
\text { Derrocamentos, } \\
\text { etc. }\end{array}$ & $\begin{array}{ll}\text { Melhorar } & \text { a } \\
\text { segurança } & \text { da } \\
\text { navegação } \\
\text { existente em } \\
\text { determinado } \\
\text { local }\end{array}$ & $\begin{array}{l}\text { Aplicável } a \\
\text { qualquer trecho } \\
\text { navegável }\end{array}$ & $\begin{array}{l}\text { Intervenções de } \\
\text { Melhoramento } \\
\text { sem mudança } \\
\text { de classe }\end{array}$ & \multirow[t]{2}{*}{$\begin{array}{l}\text { Definição do estudo e } \\
\text { do processo de } \\
\text { acordo com o porte e } \\
\text { os } \quad \text { impactos } \\
\text { potenciais. }\end{array}$} \\
\hline $\begin{array}{l}\text { Retificação, } \\
\text { Dragagens, } \\
\text { Derrocamentos, } \\
\text { etc. }\end{array}$ & $\begin{array}{l}\text { Tornar o trecho } \\
\text { navegável }\end{array}$ & Trecho C-D & $\begin{array}{l}\text { Intervenções de } \\
\text { Implantação }\end{array}$ & \\
\hline $\begin{array}{l}\text { Retificação, } \\
\text { Dragagens, } \\
\text { Derrocamentos, } \\
\text { etc. }\end{array}$ & $\begin{array}{lr}\text { Transformar } & 0 \\
\text { trecho } & \text { em } \\
\text { Classe 1 } & \end{array}$ & Trecho A-B & $\begin{array}{l}\text { Intervenções de } \\
\text { Melhoramento } \\
\text { com mudança } \\
\text { de classe }\end{array}$ & $\begin{array}{l}\text { Licenciamento } \\
\text { ambiental do conjunto } \\
\text { das intervenções } \\
\text { necessárias. Definição } \\
\text { do estudo e do } \\
\text { processo de acordo } \\
\text { com o porte e os } \\
\text { impactos potenciais. }\end{array}$ \\
\hline $\begin{array}{l}\text { Construção de } \\
\text { canal }\end{array}$ & $\begin{array}{l}\text { Fazer } \\
\text { interligação } \\
\text { hidroviária entre } \\
\text { os rios Anchieta } \\
\text { e Pitangui } \\
\end{array}$ & Não aplicável & $\begin{array}{l}\text { Implantação de } \\
\text { Canal }\end{array}$ & $\begin{array}{l}\text { Licenciamento } \\
\text { ambiental ordinário } \\
\text { com base em } \\
\text { EIA/RIMA }\end{array}$ \\
\hline
\end{tabular}




\section{CONCLUSÕES E RECOMENDAÇÕES}

Esta dissertação de mestrado assumiu como objetivo contribuir para a formulação de uma abordagem metodológica que auxilie a definição de procedimentos de avaliação ambiental de atividades e empreendimentos hidroviários, em especial o planejamento e o licenciamento ambiental. Partiu-se de uma constatação de que os procedimentos de avaliação ambiental dos projetos hidroviários no Brasil não estão bem definidos e apresentam grandes controvérsias em sua adoção.

Para tal propósito, apoiou-se em uma metodologia aplicada, qualitativa e exploratória e se utilizou de pesquisas bibliográficas e documentais, assim como em levantamento de informações com especialistas e entidades com experiência no assunto.

O marco teórico e conceitual forneceu uma base relevante ao desenvolvimento da pesquisa, como a melhor compreensão sobre o transporte hidroviário interior e a questão ambiental relacionada a esse modo de transporte.

A partir dessa referência, foi possível discorrer de forma mais apropriada sobre os principais aspectos relacionados ao transporte hidroviário. Com o intuito de compreender melhor o transporte hidroviário, foram abordadas as definições existentes, o histórico, as características mais relevantes e o potencial do transporte hidroviário no Brasil e no mundo. A fim de alcançar os objetivos desta pesquisa foram discutidas ainda as principais atividades hidroviárias, com foco na infraestrutura das vias navegáveis. Essa etapa cumpriu um dos objetivos específicos do trabalho. Outra questão importante tratada neste trabalho foi a classificação das vias navegáveis. A classificação das vias em grupos de características de navegabilidade semelhantes é um passo fundamental para a gestão no setor hidroviário. A esse respeito, foram apresentados sistemas de classificação utilizados no mundo e iniciativas de classificação no Brasil.

Posteriormente, foram estudadas e descritas as principais intervenções hidroviárias, que são obras ou serviços de engenharia necessários a incrementar ou auferir condições de navegabilidade em um curso d'água. As principais intervenções realizadas ou debatidas no País são as dragagens, derrocamentos e construção de barragens. Além das intervenções, existem os serviços rotineiros como a sinalização e o balizamento. 
As intervenções foram classificadas com base em suas características gerais, pois cada tipologia merece controles e procedimentos diferenciados. Nesse sentido, foi proposta, no contexto desta pesquisa, a divisão das atividades hidroviárias em quatro grupos principais. Esses grupos foram: implantação de canais, intervenções de implantação, intervenções de melhoramento e intervenções de manutenção.

Tendo como referência experiências nacionais e internacionais, foram analisadas as questões ambientais, partindo-se dos impactos ambientais dos sistemas de transportes, passando pelos impactos dos projetos hidroviários e, finalmente, cada uma das principais intervenções. Foi realizado, ainda, um exame das normas ambientais nacionais para dragagens. Atendeu-se, assim, a um dos objetivos específicos desta pesquisa.

Tratadas e discutidas as questões afetas ao transporte hidroviário interior e as questões ambientais relacionadas, partiu-se para a avaliação e a elaboração de propostas para a incorporação da questão ambiental no planejamento do setor e para o licenciamento ambiental das atividades e empreendimentos hidroviários.

Tendo em vista o caráter exploratório do trabalho, a consulta aos especialistas para verificação das propostas desenvolvidas foi uma etapa de importância prevista na metodologia desta pesquisa. Por meio dessa atividade chegou-se a avaliações e observações que respaldaram os conceitos gerais e auxiliaram no aperfeiçoamento da abordagem metodológica proposta.

A proposta de abordagem para definição do procedimento de licenciamento ambiental foi aplicada a um estudo de caso. Mesmo recorrendo-se a situações hipotéticas pôde-se concluir pela pertinência da abordagem, o que satisfaz a um dos objetivos específicos do presente trabalho.

Para o objetivo proposto, a metodologia de pesquisa aplicada foi satisfatória e realmente se mostrou adequada. Entende-se que poderão ser realizados mais trabalhos utilizando outras estratégias metodológicas. Considera-se, nesse sentido, a realização de pesquisas aplicadas à questão, utilizando, entre outras, abordagens quantitativas, experimentais e estudos de caso.

Quanto ao objeto da pesquisa, trata-se de uma proposta de abordagem metodológica de procedimentos de avaliação ambiental de projetos hidroviários. Nesse sentido, cabe lembrar que se restringiu o objeto da pesquisa aos projetos relacionados à navegabilidade, ou seja, à infraestrutura da via navegável. Essa delimitação se fez muito importante, pois além de características diferenciadas, os 
elementos e os atributos da navegação se encontram em um arranjo institucional complexo e em esferas diferentes de governabilidade no contexto nacional atual. Mesmo com essa limitação, permanecia o desafio de desenvolver um método que se mostrasse adequado à avaliação ambiental de projetos hidroviários, tendo em vista a já citada complexa realidade técnica e institucional.

Em relação ao THI, pôde-se confirmar que esse apresenta enorme potencial no Brasil, além de muitas vantagens sociais, econômicas e ambientais quando comparado ao transporte rodoviário e ferroviário. Apesar disso, reiterou-se que sua utilização não deve ser considerada de forma isolada, pois esse modo é dependente de integrações intermodais para sua plena utilização. Nesse sentido, reforçou-se o entendimento de que o transporte hidroviário deve ser parte de uma rede de transporte intermodal, no qual trabalhe em conjunto com os outros modos.

Quanto à questão ambiental, ressalta-se que o modo hidroviário apresenta, quando comparado a outros modais, menores impactos referentes à ocupação e uso do território. Nesse contexto, infere-se que o controle de vários dos impactos dos modos de transporte está relacionado ao planejamento territorial e às políticas públicas. Deduz-se dessa constatação a prioridade em aprimorar os processos de planejamento tanto territorial quanto setorial. O que deve ser observado nos empreendimentos de transporte é sua inserção no contexto e não a busca por solução de problemas não resolvidos pelas instituições competentes.

Em relação ao desenvolvimento territorial, o sistema de transportes deve ser considerado como parte de uma política de desenvolvimento mais amplo, e não como um fim em si. Desse modo, o sistema de transportes teria como premissa atender a um processo de desenvolvimento iniciado ou contribuir para um desenvolvimento planejado. Não seria adequado, dessa forma, que o desenvolvimento de uma dada região fosse analisado sob a ótica de um projeto de um empreendimento de transportes. Entende-se que o ideal seria que os empreendimentos atendessem às necessidades dos planejamentos territoriais estabelecidos.

Adicionalmente, cabe ressaltar que o transporte hidroviário depende de um ambiente preservado e é impactado por várias atividades existentes na bacia hidrográfica. Entre os principais degradadores dos cursos d'água estão os inadequados uso e ocupação do solo na bacia hidrográfica. Nessa circunstância, há necessidade de um controle ambiental sobre a geração de sedimentos e outras 
fontes de poluição, difusas e pontuais. Há, sob essa dimensão, convergência de interesses entre as áreas ambiental e de transportes, uma vez que, para a manutenção das hidrovias com o menor número de intervenções, é importante a conservação da bacia hidrográfica de contribuição do trecho navegável. Confirmase, nesse sentido, a apropriada declaração de Padovezi (2003) que escreve que a "preservação ambiental interessa diretamente à navegação".

Em relação à avaliação ambiental dos projetos de $\mathrm{AEH}$ no Brasil, ficou patente a pertinência da evolução no processo de planejamento do setor, desde a definição das políticas à execução. Cabe citar que o setor hidroviário desenvolveu, nos últimos anos, vários estudos, sendo o mais recente o Plano Hidroviário Estratégico - PHE, elaborado pelo Ministério dos Transportes. O PHE foi publicado no final de 2013, momento em que esta pesquisa já se encontrava em estágio avançado. Por esse motivo, o referido estudo não foi analisado e incorporado no presente trabalho.

As propostas desenvolvidas nesta pesquisa não almejam definir soluções definitivas para os problemas na avaliação ambiental de atividades $e$ empreendimentos hidroviários identificados e apresentados ao longo desta pesquisa, mas, certamente constitui um passo inicial na busca de dirimir indefinições que podem gerar cada vez mais problemas.

Consideradas suas limitações, mas também a adequabilidade apresentada, pode-se considerar que uma das principais contribuições desta pesquisa foi propor uma sistemática, com bases técnicas e analíticas, de trabalhar uma questão pouco estudada no País, e que acarreta vários efeitos negativos reais.

Trata-se em realidade, de uma pesquisa exploratória sobre esse tema específico, o que enseja reflexões sobre novas modalidades de estudos sobre essa questão. Nesse sentido, pode-se recomendar que se promovam mais pesquisas em relação ao tema. Futuras investigações que poderiam ser realizadas são: estudos de casos aplicados às situações concretas encontradas em bacias hidroviárias brasileiras; estudos sobre metodologias de avaliação de impactos ambientais aplicadas ao setor hidroviário; estudos de impactos específicos das AEH e medidas de mitigação; detalhamentos maiores dos procedimentos discutidos neste trabalho $\mathrm{e}$ da elaboração de estudos ambientais com base no porte e características ambientais. 
Considerando a carência de dados ambientais sistematizados relativos ao setor hidroviário brasileiro, surge como uma recomendação prática, a criação de um banco de dados padronizado, que poderia proporcionar mais uniformidade e transparência às informações, que hoje ficam restritas às unidades locais, o que possibilitaria dispor de elementos comparativos para avaliação, gestão e tomada de decisão. Outra recomendação prática seria a formulação de quadro normativo sobre o tema.

Por fim, ressalta-se que este estudo constitui apenas uma contribuição para o conhecimento do tema, desenvolvendo umas das possíveis abordagens metodológicas para a avaliação ambiental de projetos hidroviários. Dada a importância do tema e a ausência de reflexões mais aprofundadas, considera-se que há muito ainda a percorrer no campo da pesquisa e do estudo nesta área. 


\section{BIBLIOGRAFIA}

ALMEIDA, E. S. A questão da eficiência dos modos de transportes. Informações FIPE, n.27, p. 23 -24. São Paulo, 2001.

ALMEIDA, A. Hidrovia Tocantins-Araguaia: importância e impactos econômicos, sócias e ambientais segundo a percepção dos agentes econômicos locais. 155 p. Tese (Doutorado) - Escola Superior de Agricultura Luiz de Queiroz. Piracicaba, 2004.

ALMEIDA, C. E.; BRIGHETTI, G. Navegação Interior e Portos Marítimos. 147 p. Notas de Aula PHD 523 - EPUSP. São Paulo, 1980.

AZAMBUJA, J. L. F. Hidrovia da Lagoa Mirim: um marco de desenvolvimento nos caminhos do MERCOSUL. 181 p. Mestrado profissionalizante. Universidade Federal do Rio Grande do Sul - Escola de Engenharia. Porto Alegre, 2005.

BASTOS, M. M. R. D. Geografia dos Transportes: Trajetos e Conflitos nos Percursos Fluviais da Amazônia Paraense: Um Estudo Sobre Acidentes em Embarcações. 115 p. Dissertação (Mestrado) - Programa de Pós-Graduação em Geografia da Universidade Federal de Uberlândia. Uberlandia, 2006.

BEUTHE, M.; DEGRANDSART, F.; GEERTS, J. F.; JOURQUIN, B. External costs of the Belgian interurban freight traffic: a Network Analysis of their Internalization. Journal: Transportation Research Part D-transport and Environment, vol. 7, no. 4, pp. 285-301, 2002. Disponível em: <http://academic.research.microsoft.com/Author/23601278/michel-beuthe>. Acesso em: 08/03/2013.

BRANDT, W. Licenciamento ambiental em hidrovias. Parecer Técnico. Belo Horizonte, 2003.

BRASIL. Lei no 5.917, de 10 de setembro de 1973. Aprova o Plano Nacional de Viação e dá outras providências. Disponível em: <http://www.planalto.gov.br>.

BRASIL. Lei $n^{\circ}$ 6.630, de 16 de abril de 1979. Altera disposições da Lei $n^{\circ}$ 5.917, de 10 de setembro de 1973, que "aprova o Plano Nacional de Viação e dá outras providências”. Disponível em: <http://www.planalto.gov.br>.

BRASIL. Lei no 6.938, de 31 de agosto de 1981. Dispõe sobre a Política Nacional do Meio Ambiente, seus fins e mecanismos de formulação e aplicação e dá outras providências. Disponível em: <http://www.planalto.gov.br>.

BRASIL. Decreto no 87.566, de 16 de setembro de 1982. Promulga o Texto da Convenção sobre Prevenção da Poluição Marinha por Alijamento de Resíduos e outras Matérias, concluída em Londres, a 29 de dezembro de 1972.

BRASIL. Ministério do Meio Ambiente, Conselho Nacional de Meio Ambiente, CONAMA. Resolução CONAMA n 001, de 23 de janeiro de 1986. Disponível em: $<$ http://www.mma.gov.br>. 
BRASIL. Decreto no 1.530, de 22 de junho de 1995a. Declara a entrada em vigor da Convenção das Nações Unidas sobre o Direito do Mar, concluída em Montego Bay, Jamaica, em 10 de dezembro de 1982.

BRASIL. Lei no 9.074, de 07 de julho de 1995b. Estabelece normas para outorga e prorrogações das concessões e permissões de serviços públicos e dá outras providências. Disponível em: <http://www.planalto.gov.br>.

BRASIL. Lei no 9.433, de 8 de janeiro de 1997a. Institui a Política Nacional de Recursos Hídricos, cria o Sistema Nacional de Gerenciamento de Recursos Hídricos, regulamenta o inciso XIX do art. 21 da Constituição Federal, e altera o art. $1^{\circ}$ da Lei oㅡ 8.001, de 13 de março de 1990, que modificou a Lei no 7.990 , de 28 de dezembro de 1989. Disponível em: <http://www.planalto.gov.br>.

BRASIL. Lei no 9.537, de 11 de dezembro de 1997b. Dispõe sobre a segurança do tráfego aquaviário em águas sob jurisdição nacional e dá outras providências. Disponível em: <http://www.planalto.gov.br>.

BRASIL. Ministério do Meio Ambiente, Conselho Nacional de Meio Ambiente, CONAMA. Resolução CONAMA no 237, de 19 de dezembro de 1997c. Disponível em: <http://www.mma.gov.br>.

BRASIL. Ministério dos Transportes. Política Ambiental do Ministério dos Transportes. Brasília, 2003a.

BRASIL. Ministério do Meio Ambiente, Conselho Nacional de Recursos Hídricos CNRH. Resolução no 32, de 15 de outubro de 2003b. Disponível em: $<$ http://www.mma.gov.br>.

BRASIL. Ministério do Meio Ambiente, Conselho Nacional de Meio Ambiente, CONAMA. Resolução CONAMA no 344, de 25 de março de 2004a. Disponível em: $<$ http://www.mma.gov.br>.

BRASIL. Ministério do Meio Ambiente, Conselho Nacional de Recursos Hídricos CNRH. Resolução no 37, de 26 de março de 2004b. Disponível em: $<$ http://www.mma.gov.br>.

BRASIL. Agência Nacional de Águas - ANA. A navegação interior e sua interface com o setor de recursos hídricos. 49p. Superintendência de Usos Múltiplos Agência Nacional de Águas - Ministério do Meio Ambiente (Cadernos de Recursos Hídricos). Brasília, 2005.

BRASIL. Ministério do Meio Ambiente. Caderno setorial de recursos hídricos: transporte hidroviário. 120 p. Ministério do Meio Ambiente (MMA) - Secretaria de Recursos Hídricos. Brasília, 2006a.

BRASIL. Tribunal de Contas da União. Avaliação do Programa Manutenção de Hidrovias. 36p. Acórdão n. 351/2006. Relator Ministro Augusto Nardes. TCU, Secretaria de Fiscalização e Avaliação de Programas de Governo. (Sumários Executivos. Nova Série; 6). Brasília, 2006b. 
BRASIL. Tribunal de Contas da União. Relatório de avaliação de programa: Programa Manutenção de Hidrovias / Tribunal de Contas da União; Relator Ministro Augusto Nardes. - TCU, Secretaria de Fiscalização e Avaliação de Programas de Governo. 112p. Brasília, 2006c.

BRASIL. Agência Nacional de Águas - ANA. A Navegação Interior e sua Interface com o Setor de Recursos Hídricos no Brasil e Aproveitamento do Potencial Hidráulico para Geração de Energia no Brasil. 170 p. Superintendência de Planejamento de Recursos Hídricos - Agência Nacional de Águas - Ministério do Meio Ambiente. Brasília, 2007a.

BRASIL. Ministério dos Transportes / Ministério da Defesa. Plano Nacional de Logística e Transportes - PNLT - Relatório Executivo. Brasília, 2007b.

BRASIL. Normas da Autoridade Marítima para Auxílio à Navegação, da Diretoria de Hidrografia e Navegação da Marinha do Brasil - NORMAM-17/DHN, $3^{a}$ edição, 2008. Disponível em: <https://www.mar.mil.br >

BRASIL. Instituto Brasileiro do Meio Ambiente e dos Recursos Naturais Renováveis - IBAMA. Nota Técnica no 103/2009 - COTRA/CGTMO/DILIC/IBAMA, 10 de setembro de 2009. Brasília, 2009.

BRASIL. Ministério dos Transportes. Diretrizes da Política Nacional de Transporte Hidroviário. Ministério dos Transportes. Brasília, 2010a.

BRASIL. Ministério do Meio Ambiente, Conselho Nacional de Meio Ambiente, CONAMA. Resolução CONAMA no 421, de 03 de fevereiro de 2010b. Disponível em: <http://www.mma.gov.br>.

BRASIL. Lei Complementar oㅜ 140, de 08 de dezembro de 2011a. Disponível em: $<$ http://www.planalto.gov.br>.

BRASIL. Lei no 12.379, de 06 de janeiro de 2011b. Disponível em: <http://www.planalto.gov.br>.

BRASIL. Ministério dos Transportes. Projeto de Reavaliação de Estimativas e Metas do PNLT - Relatório Final (PNLT 2011). Brasília, 2012a.

BRASIL. Agência Nacional de Águas - ANA. Resolução no 463, de 03 de setembro de 2012b. Disponível em: <http://www.ana.gov.br>.

BRASIL. Ministério do Meio Ambiente, Conselho Nacional de Meio Ambiente, CONAMA. Resolução CONAMA no 454, de 01 de novembro de 2012c. Disponível em: <http://www.mma.gov.br>.

BRASIL. Breve Histórico sobre a Evolução do Planejamento Nacional de Transportes. Departamento Nacional de Infraestrutura de Transportes - DNIT. Disponível em: <http://www.dnit.gov.br/planejamento-e-pesquisa/historico-doplanejamento-de-transportes>. Acesso em: 10/01/2013a. 
BRASIL. Ministério dos Transportes - Infraestrutura Hidroviária. Disponível em: <http://www.transportes.gov.br/>. Acesso em 05/04/2013b.

BRASIL. Plano Nacional de Integração Hidroviária - PNHI. Agência Nacional de Transportes Aquaviários - ANTAQ e Laboratório de Transportes e Logística LABTRANS/UFSC. Brasília, 2013c.

BRIGHETTI, G. Obras de Regularização de Leito. Notas de Aula PHD 5023 - Obras Fluviais. 27 p. São Paulo: EPUSP, 2001a.

BRIGHETTI, G. Obras Fluviais. Notas de Aula PHD 5023 - Obras Fluviais. 71 p. São Paulo, SP: EPUSP, $2001 b$.

CANADA. Canadian Sediment Quality Guidelines for the Protection of Aquatic Life. Canadian Environmental Quality Guidelines - Summary Tables. Gatineau, Quebec, Canadá, 2002.

CARVALHO, F. S. Análise Multicritério de Projetos de Transporte Hidroviário Interior. 194 p. Tese (doutorado) - Universidade Federal do Rio de Janeiro Programa de Engenharia Oceânica - UFRJ/ COPPE. Rio de Janeiro, 2008.

CCME. Canadian Council of Ministers of the Environment. Criteria for the Assessment of Sediment Quality in Quebec and Application Frameworks: Prevention, Dredging and Remediation (Criteria Quality Canada) Environment Canada and Ministère du Développement durable, de 'Environnement et des Parcs du Québec, 2007.

CEBRAC. Hidrovia Paraguai-Paraná. Quem paga a conta? Análise da Viabilidade Econômico-Financeira do Projeto da Hidrovia Paraguai-Paraná. Texto para discussão. Publicação conjunta: CEBRAC/ICV/WWF. Brasília, setembro de 1994.

CHAIN Jr., M. Hidrovia Paraguai-Paraná e seus Aspectos Sócio-EconômicoAmbiental. In: Fórum Nacional de Hidrovias,1., 2001, São Paulo. Anais. São Paulo: IBC, 2001.

CHAMORRO, J. C. D. A modernização da hidrovia do Paraguai e as transformações no espaço regional: o caso da Microrregião Geográfica do Baixo Pantanal. 158 p. Dissertação (Mestrado em Geografia) - Universidade Federal da Grande Dourados. Dourados (MS), 2009.

COM. Tornar o transporte mais ecológico. Comunicação da Comissão ao Parlamento Europeu e ao Conselho. Comissão das Comunidades Europeias. COM(2008) 433 final. Bruxelas, 2008.

COSTA, L. S. S. As hidrovias interiores do Brasil. Serviço de Documentação da Marinha, Coleção Amigos do Livro Naval. Rio de Janeiro, 1998.

DINIZ, M. A. A. Sistema de Gestão Ambiental para Obras Fluviais. 132 p. Dissertação (Mestrado) - Instituto Militar de Engenharia. Rio de Janeiro, 2007. 
DINIZ, M. A. A.; SINAY, M. C. F.; FERRO, M. A. C. Gerenciamento Ambiental de Obras Fluviais apoiado em SIG. In: XXIANPET, 2007, Rio de Janeiro. XXI ANPET. Rio de Janeiro, 2007.

EASTMAN, S. E. "Fuel Efficiency in Freight Transportation." American Waterway Operators, Inc., Arlington, Virginia, 1980.

ECMT. Inland Waterways and Environmental Protection. ECMT - European Conference of Ministers of Transport - ECMT. OECD Publications Service. Paris, France, 2006.

EUROPEAN COMMISSION. Assessment of Plans and Projects Significantly Affecting Natura 2000 Sites: Methodological Guidance on the Provisions of Article 6(3) and (4) of the Habitats Directive 92/43/EEC, Office for Official Publications of the European Communities, Luxembourg, 2001.

EUROPEAN COMMISSION. The SEA Manual - a Sourcebook on Strategic Environmental Assessment of Transport Infrastructure Plans and Programmes, by Directorate-General Energy \& Transport. BEACON - Building Environmental Assessment Consensus. Brussels, 2005

EUROPEAN COMMISSION. Guidance document on Inland waterway transport and Natura 2000 - Sustainable inland waterway development and management in the context of the EU Birds and Habitats Directives, 2012.

FDEP. Florida Department of Environmental Protection. Approach to the Assessment of Sediment Quality in Florida Coastal Waters. Development and Evaluation of Sediment Quality Assessment Guidelines. Tallahassee, FL, v. I, 1994.

FERREIRA, A. N. Estudo de Acidentes na Hidrovia Tietê-Paraná: Aspectos Preventivos. 168p. Dissertação (Mestrado) - Escola Politécnica da Universidade de São Paulo - Departamento de Engenharia Naval e Oceânica. São Paulo, 2000.

FILIPPO, S. Subsídios para a gestão ambiental do transporte hidroviário interior no Brasil. 302 p. Tese (Mestrado) - Ciências em Engenharia de Transportes - Instituto Militar de Engenharia. Rio de Janeiro, 1999.

FUNDAÇÃO JOÃO PINHEIRO. Programas Especiais de Desenvolvimento dos Estados de Mato Grosso e Mato Grosso do Sul. PROSUL - Programa Especial de Desenvolvimento do Estado de Mato Grosso do Sul - V.11 - Belo Horizonte, 1979.

GARAVENTTA, M. Avaliação de riscos e determinação de efeitos de acidentes no sistema de transporte hidroviário de cargas perigosas provenientes da REFAP. 126 p. Dissertação (Mestrado) - Programa de Pós-Graduação em Engenharia Mecânica, PROMEC, da Escola de Engenharia da Universidade Federal do Rio Grande do Sul. Porto Alegre, 2008.

GOULART, F. F.; SAITO, C. H. Modelagem dos impactos ecológicos do projeto hidroviário da Lagoa Mirim (Brasil-Uruguai), baseada em raciocínio qualitativo. Braz. J. Aquat. Sci. Technol. 16(1): 19-31, 2012. 
GUIA GEOGRÁFICO - Brasil Turismo. Disponível em: <http://www.brasilturismo.com>. Acesso em: 05/04/2013.

HUSZAR, P., PETERMANN P., LEITE A., RESENDE E., SCHNACK E., SCHNEIDER E., FRANCESCO F., RAST G., SCHNACK J., WASSON J., GARCIA LOZANO L., DANTAS M., OBRDLIK P., PEDRONI R. Realidade ou Ficção: Uma Revisão dos Estudos Oficiais da Hidrovia Paraguai-Paraná. WWF. 46 pp.Toronto, Canada, 1999.

ICPDR. Development of inland navigation and environmental protection in the Danube river basin. Joint Statement on Guiding Principles. ICPDR - International Commission for the Protection of the Danube River. Vienna, Austria. 2007

ICPDR. "Manual on Good Practices in Sustainable Waterway Planning". PLATINA EU International Commission for the Protection of the Danube River - ICPDR. Vienna, Austria, 2010. Disponível em: <http://www.naiades.info/downloads>. Acesso em 10/11/2013.

IMO. London Convention. Specific guidelines for assessment of dredged material. International Maritime Organization - IMO, London, UK, 1996.

LAKSMANAN, T. R.; SUBRAMANIAN, U.; ANDERSON, W. P.; LÉAUTIER, F. A. Integration of transport and trade facilitation: selected regional case studies. Washington: The World Bank, 2001. 144p.

LIMA, C. A. N.; OLIVEIRA, I. G. Relação entre a intensificação do uso do solo e o aumento das dragagens na hidrovia do rio Paraguai. Anais XIII Simpósio Brasileiro de Sensoriamento Remoto, Florianópolis, Brasil, 21-26 abril 2007, INPE, p. 27612768.

LONG, E.R., MACDONALD, D.D., SMITH, S.L., CALDER, D. Incidence of adverse biological effects within ranges of chemical concentrations in marine and estuarine sediments. Environmental Management, p. 81-97. 1995.

MARCELA, D.; CLAUDIO, D. Plan de Gestión Ambiental de la Vía Navegable Troncal: Secciones Santa Fe - Océano y Santa Fe - Confluencia. V Congresso Iberoamericano sobre Desarrollo y Ambiente de REDIBEC. Santa Fe - Argentina, 2011.

MILARÉ, E.; PEREIRA, M. S.; RODRIGUES, J. R. Licenciamento e avaliação de impacto ambiental de hidrovias. Opinião Legal. São Paulo, 2004.

NAZARÉ, R. O Complexo Amazônico e sua Navegação Interior. Belém, CEJUP, 1993.

OECD. Environmental Impact Assessment of Roads. Organization for Economic Cooperation and Development - OECD (Chapter II, Strategic Environmental Impact Assessment). Scientific Expert Group El. Paris. 1994

ONU. Convenção das Nações Unidas sobre o Direito do Mar - Organização das Nações Unidas, 1982. 
OTTONI, B. A. A Implantação de Sistemas de Navegação em Regiões Estuarinas. Tese COPPE/UFRJ, Rio de Janeiro, 1986

PADOVEZI, C.D. Conceito de embarcações adaptadas à via aplicado à navegação fluvial no Brasil. 215 p. Tese (Doutorado) - Escola Politécnica da Universidade de São Paulo. Departamento de Engenharia Naval e Oceânica. São Paulo, 2003.

PAKISTAN. Pakistan Strategic Environmental, Poverty and Social Assessment of Trade and Transport Sector Reforms. Report No 71812-PK. Environment, Climate Change and Water Resources Department South Asia Region Document of the World Bank. December 2012

PIANC. Guidelines for Sustainable Inland Waterways and Navigation. Report of Working Group 6 of the Environmental Commission. International Navigation Association - PIANC. Brussels, 2003.

PIANC. Dredging Management Practices for the Environment - A Structured Selection Approach. Report no 100. Environmental Commission. 2008a.

PIANC. Position Paper "Working with Nature". The World Association for Waterborne Transport Infrastructure - PIANC. October, 2008b.

PORTUGAL. Relatório Ambiental - Avaliação Ambiental Estratégica - Plano Estratégico de Transportes. Departamento de Ciências e Engenharia do Ambiente. Faculdade de Ciências e Tecnologia - FCT. Universidade Nova de Lisboa - UNL. Lisboa, Portugal, 2009

PRADO, F.C. \& COTA, M.A.P. Dragagens Fluviais. Informação Técnica DHI, Brasília, 1998.

RODRIGUE, J.P. The Geography of Transport Systems. Length of the Major Inland Waterway Systems, $2000 . \quad$ Disponível em: <http://people.hofstra.edu/geotrans/eng/ch3en/conc3en/lengthwaterways.html> Acesso: 05/04/2013.

ROSSETTO Jr., O. F. Hidrovia Tietê-Paraná - Projetos e Ações em Desenvolvimento. Departamento Hidroviário - Secretaria dos Transportes Governo do Estado de São Paulo. 1 Encontro de Logística e Transportes no Oeste Paulista - Hidrovia Tietê-Paraná - Alavanca do Desenvolvimento. Araçatuba, 2005

SANTANA, W. A. Proposta de diretrizes para planejamento e gestão ambiental do transporte hidroviário no Brasil. 277 p. Tese (Doutorado)- Escola Politécnica da Universidade de São Paulo - Departamento de Engenharia Naval e Oceânica. São Paulo, 2008.

SANTANA, W. A.; TACHIBANA, T. Caracterização dos elementos de um projeto hidroviário, vantagens, aspectos e impactos ambientais para a proposição de metodologias técnico-ambientais para o desenvolvimento do transporte comercial de cargas nas hidrovias brasileiras. ENGEVISTA, v. 6, n. 3, p. 75-85, dezembro 2004. 
SCHÄFER, A. Introducing behavioral change in transportation into energy/economy/environment models. Policy Research working paper; no. WPS 6234. Washington, DC: World Bank. 2012

SCHAPPO, C. W.; ROSSI, L.; BAZZO, W. A.; PEREIRA, L. T. V. Transporte Hidroviário Brasileiro: um problema para o ensino de engenharia. In: Congresso Brasileiro de Educação em Engenharia, 2008, São Paulo. XXXVI COBENGE. São Paulo: USP-ABENGE, 2008. v. 1. p. 01-10.

SILVA, E. O. Aplicação do geoprocessamento na implantação e na operação de hidrovias. 206 p. Dissertação (Mestrado) - Instituto Militar de Engenharia. Rio de Janeiro, 2006.

SILVA, P. J. Estrutura para Identificação e Avaliação de Impactos Ambientais em Obras Hidroviárias. 511 p. Tese (Doutorado) - Escola Politécnica da Universidade de São Paulo. São Paulo, 2004.

SILVA, H. P.; ROCHA, N. M.; CASTRILLON, S. K. I. O impacto da proposta de implementação da Hidrovia Paraguai-Paraná, na visão de diversos setores da sociedade em Cáceres, MT. SIMPAN 2004 - IV Simpósio dobre Recursos Naturais e Socioeconômicos do Pantanal. Corumbá/MS. 23 a 26 de novembro de 2004.

SINAY, M. C. F.; TEIXEIRA, M. D. M.; AMORIM, J. C. C. Características da Geomorfologia Fluvial e a Navegabilidade dos Cursos d'Agua. In: Rio de Transportes III, 2005, Rio de Janeiro. Rio de Transportes III, 2005.

SLACK, N. et. al. Operations management. Pitman Publishing. London, 1997.

TAPAJÓS, D. R. Modelo de indicadores de sustentabilidade aplicável a hidrovias na Amazônia - MISAHA. 283 p. Tese (Doutorado) - Programa de Pós-Graduação em Engenharia de Recursos Hídricos e Saneamento Ambiental da Universidade Federal do Rio Grande do Sul. Porto Alegre, 2002.

UNITED KINGDOM. Strategic Environmental Assessment for Transport Plans and Programmes. Transport Analysis Guidance (TAG).TAG Unit 2.11. Department for Transport. 2004.

USACE. Analysis of environmental aspects of waterways navigation. National Waterways Study - Final Report. U.S. Army Corps of Engineers. Institute for Water Resources. Water Resources Support Center. Fort Belvoir, 1981.

USACE. U.S. Port and Inland Waterways Modernization: Preparing for PostPanamax Vessels. U.S. Army Corps of Engineers - USACE. Institute for Water Resources. June, 2012.

WORLD BANK. Ports, Maritime \& Logistics: Inland Water Transportation (IWT) Development. 2000.

WWF. Retrato da Navegação no Alto Rio Paraguai - Relatório da expedição técnica realizada entre os dias 3 e 14 de novembro de 1999, no rio Paraguai, entre Cáceres (MT) e Porto Murtinho (MS). 1ª edição. Janeiro de 2001. 


\section{APÊNDICE A - Bacias Hidroviárias}

Neste apêndice, são apresentados de forma sucinta os dados de cada uma das principais Bacias Hidroviárias.

\section{BACIA AMAZÔNICA}

Localizada na região norte do Brasil, a Bacia Amazônica é a maior bacia hidrográfica do mundo, possuindo aproximadamente sete milhões de quilômetros quadrados de extensão, sendo quatro milhões em território brasileiro. O rio principal desta bacia é o Amazonas que nasce no Peru e depois percorre o território brasileiro.

Esta bacia é formada por uma vasta malha de rios perenes e corpos d'água possuí cerca de 23 mil quilômetros de rios navegáveis. Os principais rios para navegação nesta bacia são os rios Amazonas, Solimões, Negro, Branco, Madeira, Trombetas, Tapajós, entre outros.

O transporte hidroviário na Bacia Amazônica, devido à extensa área abrangida por seu sistema fluvial, apresenta-se sobre os mais diversos aspectos, desde o de subsistência, com o transporte de pequenas cargas e passageiros, até o de maior vulto, isto é, de cabotagem ou de longo curso, onde são utilizadas grandes embarcações e portos classificados como marítimos, como Vila do Conde e Manaus.

O transporte hidroviário nesta região figura mais utilizado, tanto pela inexistência de rede rodoviária como pela extensão continental da Bacia Amazônica.

Devido à carência de rodovias e a abundância de vias navegáveis, o transporte hidroviário na Bacia Amazônica reveste-se de grande importância econômica e social. Destacam-se entre as naturezas de transporte, os granéis sólidos (grãos e minérios), derivados de petróleo e passageiros.

O Ministério dos Transportes divide a bacia amazônica em Bacia Amazônica Ocidental e Bacia Amazônica Oriental, sendo dois os órgãos responsáveis: a Administração das Hidrovias da Amazônia Ocidental (AHIMOC) e a Administração das Hidrovias da Amazônia Oriental (AHIMOR). 
A Bacia Amazônica Ocidental ocupa uma área aproximada de $2.400 .000 \mathrm{~km}^{2}$, abrangendo os Estados do Amazonas, Acre, Rondônia e Roraima. Principais Rios: Amazonas, Solimões, Juruá, Tefé, Purus, Madeira, Negro, Branco.

A Bacia Amazônica Oriental é formada por uma área de aproximadamente $1.500 .000 \mathrm{~km}^{2}$ e abrange os estados do Acre, Roraima, Rondônia, Amazonas, norte do Mato Grosso e Pará. Principais Rios: Branco, Acre, Solimões, Amazonas, Tapajós, Teles Pires, Xingu, Trombetas, Jari, Madeira, Guaporé, Guamá, Capim, Negro e Pará.

\section{BACIA DO NORDESTE}

De acordo com o Ministério dos Transportes, a Bacia do Nordeste compreende as bacias do Parnaíba, do Itapecuru, do Mearim e do Pindaré.

A Bacia do Parnaíba tem área aproximada de 327.107 km2 e abrange os estados do Maranhão e Piauí. O principal rio é o Rio Parnaíba, que também é o principal rio de toda a bacia do Nordeste.

O Rio Parnaíba tem um curso total de aproximadamente $1.334 \mathrm{~km}$, sendo navegável em corrente livre e no seu estado natural em dois trechos compreendidos entre as cidades de Uruçuí e Santa Filomena e no trecho a jusante da Barragem de Boa Esperança até a sua foz no Oceano Atlântico.

A navegação no Parnaíba é praticada por embarcações de madeira autopropulsadas, de pequeno e médio porte, com capacidade de carga variando entre 1,0 e 12,0 toneladas, no transporte de carga geral como: arroz, milho, feijão, babaçu, carnaúba, cana de açúcar, algodão, mandioca, farinha de mandioca, pescados, crustáceos e gêneros diversos, para abastecimento das populações ribeirinhas e passageiros entre as cidades e os diversos povoados ao longo da via.

Além do rio Parnaíba, a bacia hidrográfica do Nordeste é formada por diversos rios onde se pratica a navegação, principalmente no Estado do Maranhão, em pequenos trechos próximos ao litoral atlântico, ligados fundamentalmente ao tráfego local. Entre essas se destacam as do Itapecuru, do Mearim e do Pindaré.

Os principais rios da Bacia do Itapecuru são o Itapecuru, Alpercatas, Pucumã, Correntes, Santo Amaro e Itapecuruzinho.

O rio Itapecuru tem suas nascentes nas serras da Croeira e do Itapecuru, percorrendo uma extensão navegável de $565 \mathrm{~km}$, desde Colinas até sua foz. 
transporte hidroviário na bacia do Itapecuru é praticado por pequenas embarcações de madeira, autopropulsadas, com capacidade de carga variando de 2,5 a 7,0 toneladas, transportando a produção agrícola da região, carga geral e passageiros.

O rio Mearim tem curso total de aproximadamente $930 \mathrm{~km}$, sendo navegável somente em parte do alto Mearim e nos trechos médio e baixo do rio, compreendido entre a sua foz na Baia de São Marcos e a cidade de Barra do Corda. A navegação no Mearim, atualmente, é praticada por embarcações de madeira, autopropelidas (lanchas), com capacidade de carga variando entre 4 e 10 toneladas, no transporte de carga geral (arroz, milho, feijão, babaçu, farinha de mandioca, pescado, gêneros diversos, etc.) e passageiros entre os diversos povoados e cidades existentes ao longo da via.

O rio Grajaú, afluente do rio Mearim pela margem esquerda, tem bacia hidrográfica com área de aproximadamente $21.830 \mathrm{~km}^{2}$. Tem um curso total de aproximadamente $770 \mathrm{~km}$, sendo atualmente navegado por pequenas embarcações no trecho entre o povoado Mandail e sua barra no rio Mearim, numa extensão de aproximadamente $330 \mathrm{~km}$.

A Bacia do Pindaré tem como principais rios, o Pindaré e o Caru. O rio Pindaré, principal afluente do rio Mearim, nasce nas elevações que formam o divisor entre as bacias hidrográficas dos rios Mearim e Tocantins. Seu percurso total é de aproximadamente $686 \mathrm{~km}$, sendo navegável no trecho compreendido entre a sua foz no km 41 do rio Mearim até a foz do rio Buriticupu no km 456 .

\section{BACIA DO PARAGUAI}

A Bacia do Paraguai está localizada nos Estados do Mato Grosso e Mato Grosso do Sul e ocupa uma área de $2.700 .000 \mathrm{~km}^{2}$. A Hidrovia do Paraguai corta o coração da América do Sul no sentido norte-sul em uma extensão de 3.442 quilômetros, partindo da cidade de Cáceres, no estado do Mato Grosso, até Nueva Palmira, no Uruguai. Grande parte desta bacia estende-se pela planície do Pantanal Mato-Grossense. Os rios desta bacia são muito usados para a navegação. $O$ principal rio desta Bacia é o Paraguai.

A Bacia do Prata engloba um dos principais sistemas hidroviários do mundo. Foi fator determinante para a formação dos países do Cone Sul da América Latina, 
quer politicamente, como na penetração e consolidação dos estados que ali se organizaram a partir do século XVI.

Atualmente, os países da Bacia do Prata, apesar das restrições de navegação, transportam pela Hidrovia Paraguai-Paraná mais de 15 milhões de toneladas de cargas por ano, no que é considerado o segundo sistema fluvial da América do Sul em extensão, equiparando-se em navegabilidade e extensão ao rio Mississipi (EUA) e ao Reno (Europa).

Do ponto de vista econômico, como via de transporte e comunicação, tem sido fator decisivo para o desenvolvimento dos países que estão em sua área de influência. Seus cursos de água são responsáveis pelos excelentes índices de fertilidade de extensas áreas agricultáveis, constituindo-se num recurso natural capaz de gerar energia abundante. Ainda se apresenta com enorme potencialidade para as atividades industriais que requeiram fluxo de insumos em escalas cada vez maiores, para reduzir custos e atender às demandas crescentes de um mercado regional capaz de atingir as dimensões das economias mais desenvolvidas.

Além de servir a extensos territórios produtivos da Argentina, Brasil, Bolívia, Paraguai e Uruguai, beneficia também o Pacto Andino, iniciativa essa da Bolívia, Colômbia, Equador, Peru e Venezuela, impulsionando ativamente a integração econômica dessa região, constituída de uma importante zona de livre comércio com 100 milhões de habitantes.

\section{BACIA DO SÃO FRANCISCO}

A Bacia do São Francisco possui uma área de 641.000 km². Localiza-se em grande parte em território do Nordeste, entre os estados da Bahia, Sergipe e Alagoas. Porém, o trecho inicial da bacia está localizado no norte de Minas Gerais. O Rio São Francisco, Rio Grande e o Rio Corrente são os principais rios para a navegação.

A Hidrovia do São Francisco, que liga as cidade de Pirapora (MG) e Juazeiro (BA), possui uma extensão de $1.371 \mathrm{~km}$ e grande potencial de transporte de cargas, formada especialmente pela soja produzida no interior do Estado da Bahia (AZAMBUJA, 2005).

O rio São Francisco é muito importante para a irrigação de terras em seu percurso e também para a navegação. As cargas com perfil hidroviário que 
transitam pela hidrovia são: soja em grãos, milho, farelo de soja, gipsita e polpa de tomate.

O transporte na hidrovia já foi realizado pela Companhia de Navegação do São Francisco (FRANAVE), a qual pertencia quase totalmente ao Governo Federal $(99,96 \%)$, sendo o restante dividido entre os governos estaduais da Bahia e de Minas Gerais, e também entre acionistas do setor privado. Porém, a FRANAVE já não existe desde fevereiro de 2007, ano em que suas atividades foram interrompidas (BRASIL, 2013a).

\section{BACIA DO SUL}

A Bacia do Sul possui área aproximada de $223.688 \mathrm{~km}^{2}$ e abrange os estados do Rio Grande do Sul e Santa Catarina, sendo que o primeiro se destaca pela navegação. Os principais Rios são o Jacuí e o Taquari, os quais se unem e chegam à Lagoa dos Patos pelo Lago Guaíba, seguindo pelo Canal de São Gonçalo e finalmente chegando à Lagoa Mirim.

Em termos de porte de embarcação predomina o automotor com $90 \mathrm{~m}$ de comprimento, $15 \mathrm{~m}$ de boca e capacidade para aproximadamente $3.000 \mathrm{t}$, calando até $3,2 \mathrm{~m}$. As cargas consistem em milho (importação), farelo e óleo vegetal (exportação). Recentemente surgiu a exportação de cavacos de madeira, que não obstante ser transportada nas embarcações de maior porte, em função de sua baixa densidade, não permite que aquelas embarcações recebam mais de $1.800 \mathrm{t}$.

Por outro lado, há outros dois importantes transportes nas hidrovias desta bacia, elencados a seguir.

- transporte de areia "in natura" extraída do leito do rio Jacuí, destinada ao consumo imediato na construção civil Nesse caso, as embarcações tem porte diferenciado, variando entre 300 e 1.000 t de capacidade de carga.

- transporte de carvão energético, consumido no Polo Petroquímico do Sul (COPESUL), localizado nas proximidades da região metropolitana do Porto de Porto Alegre, com origem em Charqueadas, $40 \mathrm{~km}$ a montante, no rio Jacuí. Nesse caso, são utilizadas embarcações de 1.800 t de capacidade de carga. 
Esta bacia tem área aproximada de $723.520 \mathrm{~km}^{2}$, considerando somente porção à montante da barragem de Itaipu. Localiza-se em grande parte na região sudeste e sul do Brasil, região de maior desenvolvimento econômico do País e abrange os estados de Goiás, Minas Gerais, Mato Grosso do Sul, São Paulo e Paraná.

Possui grande potencial gerador de energia elétrica. Nesta bacia encontramse inúmeras usinas hidrelétricas, entre elas a de Itaipu e Porto Primavera. Os principais rios são os rios Paranaíba, Paraná e Tietê. A hidrovia Tietê-Paraná é uma importante rota de navegação nesta bacia.

Para o transporte de cargas, são utilizadas chatas, de 8 a $11 \mathrm{~m}$ de boca, com comprimentos que variam de 50 a $60 \mathrm{~m}$, sem propulsão. O carga transportada se divide em granel sólido (principalmente soja), carga geral (principalmente cana) e granel líquido (principalmente álcool) além da carga de areia a pequenas distâncias.

\section{BACIA DO TOCANTINS E ARAGUAIA}

A Bacia do Tocantins-Araguaia localiza-se na região centro-norte do Brasil, entre os estados de Tocantins, Goiás, Pará e Mato Grosso do Sul em uma área aproximada de $767.000 \mathrm{~km}^{2}$, influenciando uma grande área agricultável. Os principais rios são o Tocantins, Araguaia e das Mortes.

Esta bacia conta com $3.721 \mathrm{~km}$ de rios navegáveis, sendo $551 \mathrm{~km}$ no rio das Mortes, $1.655 \mathrm{~km}$ no rio Araguaia e $1.515 \mathrm{~km}$ no rio Tocantins, atravessando as regiões Centro-Oeste e Norte do País, ligando o Brasil Central aos portos de Belém (PA) e Vila do Conde (PA), bem como aos de Itaqui (MA) e Ponta da Madeira (MA) através da Estrada de Ferro Carajás (EFC) (BRASIL, 2005).

A região servida pela Hidrovia Tocantins-Araguaia apresenta características de alta potencialidade produtiva, em função de sua localização geográfica e condições de solo, facilitando a produção de grãos, especialmente a soja, que, em grande parcela, destina-se à exportação, e que são produtos de baixo valor unitário e de grandes volumes apresentando custo de transporte muito significativo e constituindo setores em que o mercado externo tem papel preponderante (AZAMBUJA, 2005). 


\title{
APÊNDICE B - Consultas aos Especialistas
}

\section{Correspondência eletrônica enviada aos especialistas}

\author{
Prezado(a) XXXXXXX,
}

Sou aluno de Mestrado do Programa de Pós Graduação em Tecnologia Ambiental e Recursos Hídricos (PTARH) da Universidade de Brasília - UnB. O tema da minha Dissertação de Mestrado é "Abordagem metodológica para avaliação ambiental de empreendimentos e atividades hidroviários". O orientador da pesquisa é o Prof. Oscar de Moraes Cordeiro Netto (cordeiro@unb.br).

Tendo em vista o protocolo adotado na metodologia da pesquisa, considerou-se necessário consultar especialistas do setor para avaliação e verificação de uma das etapas do trabalho desenvolvido. Nesse sentido, encaminho, em anexo, um documento que descreve essa etapa, qual seja, a proposição de uma abordagem para avaliação a priori de empreendimentos e atividades hidroviários. Gostaria, desse modo, de ter sua avaliação sobre a proposição apresentada.

Em observação aos prazos para a conclusão do trabalho, peço que me responda, por email, até o dia 21 de fevereiro de 2014. Sua participação será de enorme importância.

Além disso e/ou se preferir, o orientador Prof. Oscar de Moraes Cordeiro Netto convida-o(a) para um encontro técnico, em que será debatida esta proposição. Suas contribuições poderão também ser apresentadas à ocasião dessa reunião. Tal encontro ocorrerá no dia 22 de fevereiro (sábado) de 2014, de 09 h00 às 11h50, na sala de aula do PTARH, cujo endereço encontra-se a seguir:

Endereço:

PTARH/ENC/FT/UnB

SG-12, Térreo - UnB - Asa Norte

CEP : 70.910-900 Brasília - DF

Caso tenha alguma dúvida, sinta-se à vontade para entrar em contato comigo no email XXXXXXXXXXX@yahoo.com.br ou no telefone (XX)XXXX-XXXX.

Atenciosamente, 
UnB - UNIVERSIDADE DE BRASÍLIA

FT - FACULDADE DE TECNOLOGIA

ENC - DEPARTAMENTO DE ENGENHARIA CIVIL E AMBIENTAL

\section{CONSULTA A ESPECIALISTAS PARA ELABORAÇÃO DE PROPOSTA DE ABORDAGEM METODOLÓGICA PARA AVALIAÇÃO AMBIENTAL DE EMPREENDIMENTOS E ATIVIDADES HIDROVIÁRIOS COMO SUPORTE AO DESENVOLVIMENTO DE DISSERTAÇÃO DE MESTRADO EM TECNOLOGIA AMBIENTAL E RECURSOS HÍDRICOS}

Mestrando: Mateus Salomé do Amaral

Orientador: Oscar de Moraes Cordeiro Netto

Brasília/DF

Fevereiro/2014

\section{1 - Apresentação}

A presente consulta a especialistas tem como objetivo dar suporte à elaboração de proposta de abordagem metodológica para avaliação ambiental de empreendimentos e atividades hidroviários, tema de desenvolvimento da dissertação de Mestrado em Tecnologia Ambiental e Recursos Hídricos na Universidade de Brasília - UnB.

A motivação para elaboração do trabalho tem como base a constatação de que há pouco consenso sobre a normatização envolvendo a questão ambiental dos projetos hidroviários. Acredita-se que seja possível desenvolver uma abordagem metodológica que possa contribuir para definição do processo de licenciamento ambiental dos empreendimentos e atividades hidroviários, com 0 intuito de se imprimir maior racionalidade a esse processo, de modo que, por um lado, os impactos ambientais sejam adequadamente considerados e, por outro, os projetos sejam considerados na proporção dos riscos a eles associados.

Assim, por se tratar de pesquisa cuja essência é a formulação de uma abordagem metodológica de um tratamento ambiental de projetos da tipologia hidroviária, a formulação e a verificação das possíveis abordagens englobam não só a análise da experiência encontradas em literatura, outras referências, documentos técnicos e casos de estudo, mas também a discussão com especialistas e gestores de meio ambiente e hidroviários para permitir a construção de uma representação conceitual sobre a questão. 


\section{2 - Contexto da Análise}

As hidrovias são conhecidas como alternativas de transporte de menor custo e impacto ambiental do que rodovias e ferrovias. O transporte hidroviário é mais eficiente, apresenta menor consumo de combustíveis e menos emissões de poluentes atmosféricos. Esse modo oferece vantagens, principalmente, para 0 transporte de grandes quantidades a grandes distâncias.

Contando com uma ampla rede de drenagem, o Brasil apresenta um enorme potencial para o transporte hidroviário interior. Com o aumento da necessidade e importância do transporte hidroviário, tornaram-se mais evidentes os gargalos na infraestrutura e mais urgente a necessidade de obras de adequação, melhorias e, especialmente, manutenção nas vias navegáveis.

Por sua vez, maiores também são as preocupações ambientais da sociedade e as medidas que devem ser tomadas para proteção do meio ambiente. Nessa conjuntura, encontram-se os instrumentos da Política Nacional do Meio Ambiente, como a avaliação de impactos ambientais e o licenciamento ambiental.

No Brasil, o tratamento das questões ambientais dos projetos hidroviários tem apresentado grandes controvérsias, que vem se refletindo nos processos de licenciamento ambiental desses empreendimentos. Nesse contexto, não existe normas específicas para avaliação das questões ambientais dos empreendimentos e atividades de infraestrutura para o transporte hidroviário interior.

Ao longo do desenvolvimento da pesquisa foi desenvolvida uma proposta metodólogica de avaliação, representada nos fluxogramas apresentados na seção a seguir. É uma discussão sobre essas abordagens o objeto dessa consulta.

\section{3 - Proposta Metodológica}

O transporte hidroviário apresenta vários benefícios ambientais, mas as intervenções necessárias para garantir ou promover a navegabilidade podem causar também impactos ambientais negativos. Dessa forma, é de interesse promover um melhor planejamento para a utilização desse modo de tranporte e a aplicação de uma gestão ambiental mais eficaz. Adicionalmente, mais do que apenas cumprir 
normas legais vigentes, é desejável que a realização de licenciamento ambiental seja efetivo no controle ambiental.

Esta pesquisa englobará os dois temas, o planejamento e o licenciamento ambiental de projetos hidroviários. Como esta pesquisa se propõe a focar nos procedimentos, não há a intenção de se trabalhar com as medidas de controle, mitigação e compensação ambientais.

\section{1 - Proposta para o planejamento do setor hidroviário}

Tão importante e talvez ainda mais efetivo do que definir critérios e procedimentos para o licenciamento ambiental é promover uma evolução no processo de planejamento do setor hidroviário, desde a definição das políticas à execução dos projetos.

Nesse sentido, identifica-se a necessidade de uma proposta mais adaptada à realidade brasileira para auxiliar o planejamento do setor hidroviário. Trata-se de uma proposta inicial adaptada ao contexto atual brasileiro com o objetivo de contribuir para a melhora do planejamento do setor hidroviário no País, incorporando questões ambientais.

No fluxograma a seguir é apresentada a proposta de abordagem para ser utilizada no planejamento estratégico para o setor hidroviário. 


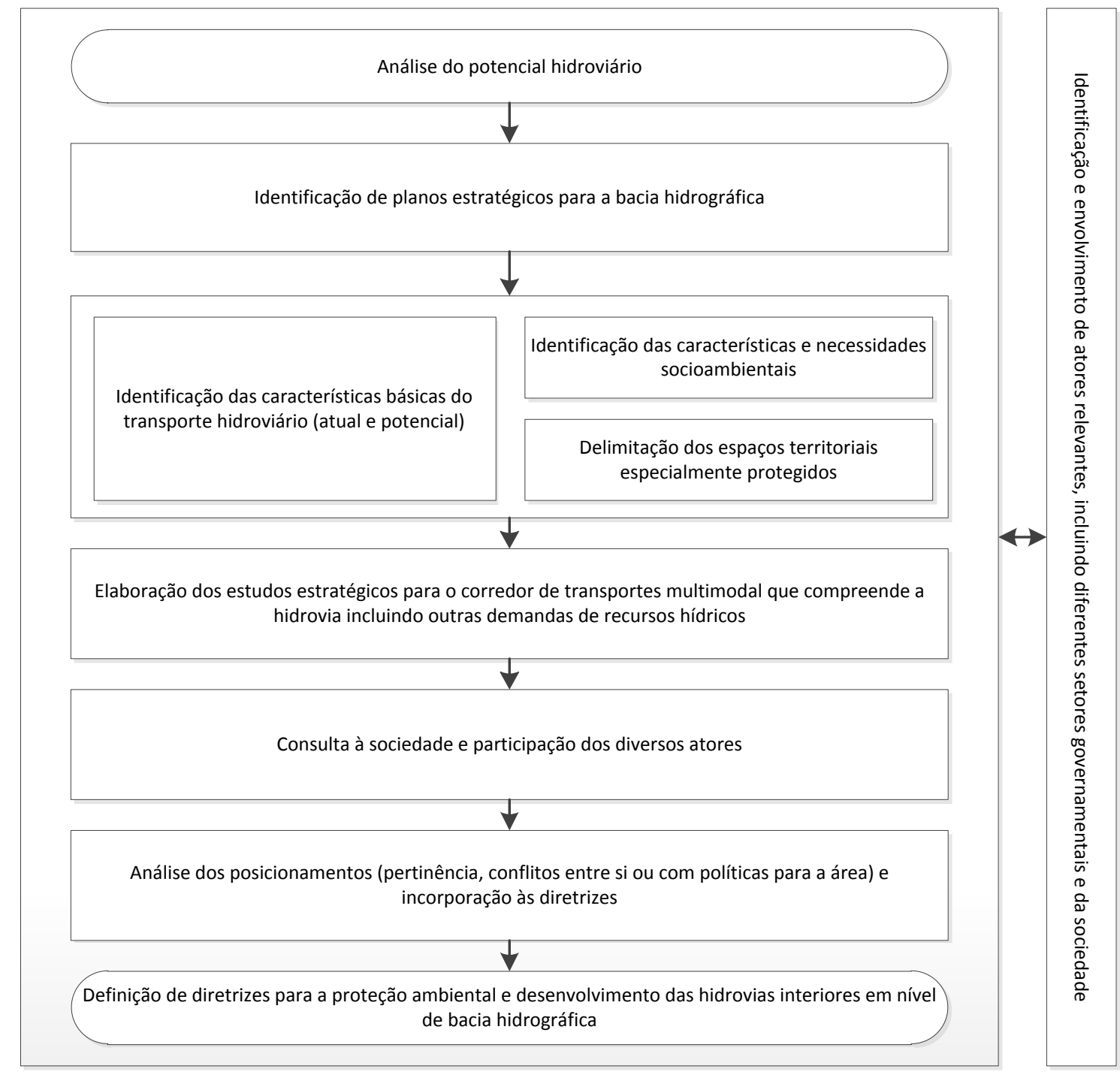

Figura 1 - Fluxograma representativo da proposta de abordagem para o planejamento estratégico do setor hidroviário.

\section{2 - Proposta para o licenciamento ambiental de intervenções hidroviárias}

Para esta proposta, serão abordados os empreendimentos e atividades relacionados à infraestrutura hidroviária. Além do empreendimento "implantação de canais", serão consideradas as "intervenções de manutenção", as "intervenções de melhoramento" e as "intervenções de implantação".

A "implantação de canais" tem o objetivo criar canais de navegação onde não há curso d'água preexistente ou os cursos d'água existentes não possibilitam nenhum tipo de navegação, com os impactos de uma implantação se assemelhando ao primeiro caso. Os canais artificiais podem ser construídos com o início e fim na 
mesma bacia ou para transposição de bacias, sendo o último mais utilizado. Esse tipo de empreendimento apresenta grande complexidade ambiental.

As "intervenções" são obras ou serviços de engenharia necessários a incrementar ou auferir condições de navegabilidade em um curso d'água.

As "intervenções de implantação" são aquelas realizadas pela primeira vez no corpo hídrico em que não há ou existiu navegação com o objetivo de viabilizar as condições de navegabilidade para uma determinada embarcação-tipo. Em seu turno, as "intervenções de melhoramento" e "manutenção" ocorrem somente em corpos d'água em que existe ou já existiu navegação.

As "intervenções de melhoramento" são aquelas que buscam melhorar a condição de navegabilidade em um curso d'água. Este grupo de intervenções é o mais amplo, pois incluem todas as intervenções não enquadradas nos demais grupos. Essas intervenções podem ter como objetivo a mudança de classe da hidrovia ou não. Diferem-se das "intervenções de manutenção", principalmente, por não se configurarem como atividades rotineiras. Por outro lado, diferenciam-se das "intervenções de implantação" por estarem em cursos d'água em que existe ou já existiu navegação.

As "intervenções de manutenção", mais corretamente denominadas atividades de manutenção, são aquelas destinadas a manter as condições estabelecidas nas intervenções de implantação e de melhoria ou das condições naturais do corpo hídrico.

Com base nessa classificação, é possível realizar uma proposta para 0 licenciamento ambiental dos projetos hidroviários. As propostas se encontram nos fluxogramas a seguir. 


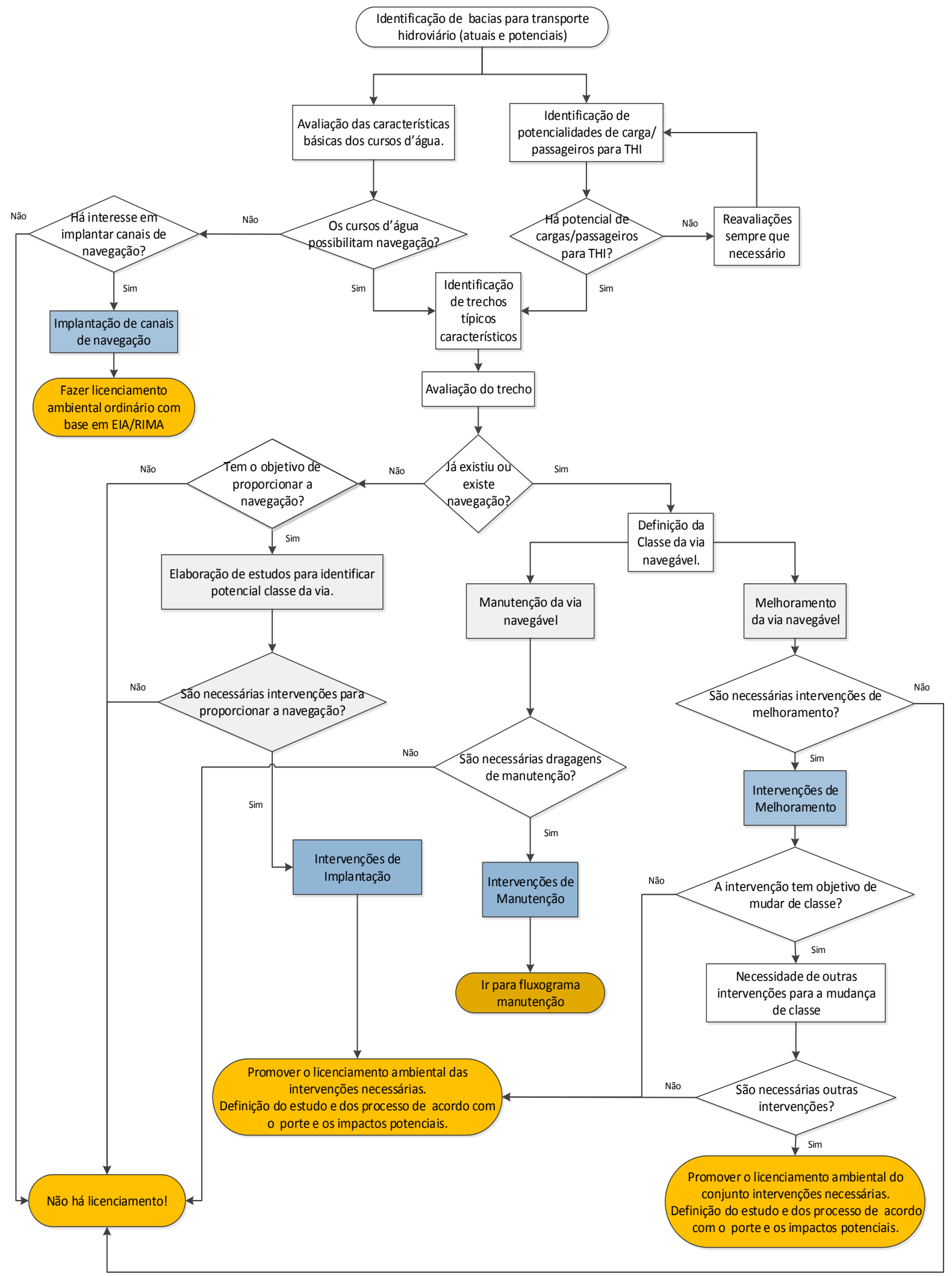

Figura 2 - Fluxograma representativo da proposta metódológica para a definição do procedimento de licenciamento ambiental de projetos hidroviários. 


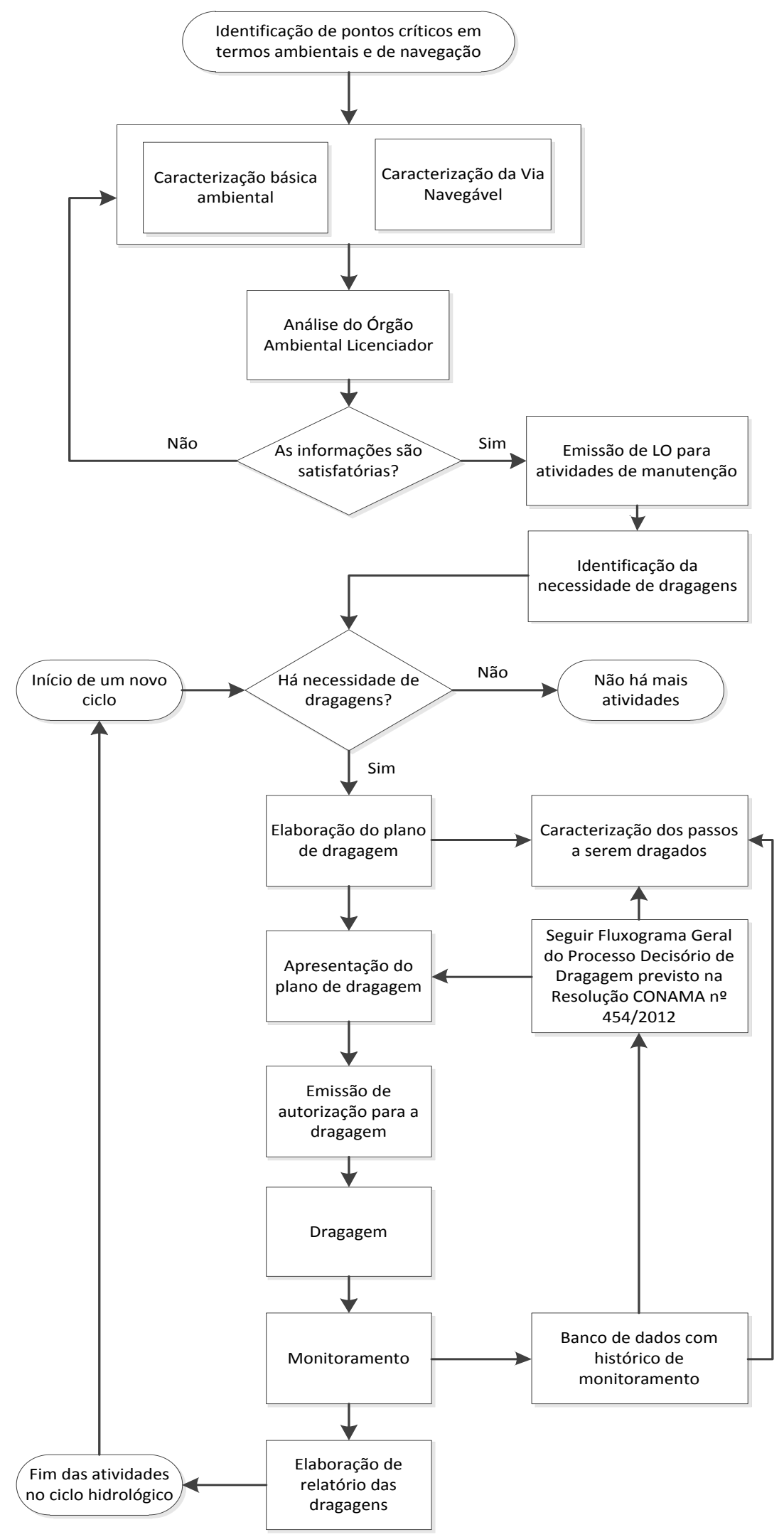

Figura 3 - Fluxograma representativo da proposta de tratamento ambiental para atividades de manutenção. 